\title{
Active ownership
}

Citation for published version (APA):

Viehs, P. M. (2013). Active ownership. [Doctoral Thesis, Maastricht University]. Universitaire Pers Maastricht. https://doi.org/10.26481/dis.20131023pv

Document status and date:

Published: 01/01/2013

DOI:

10.26481/dis.20131023pv

Document Version:

Publisher's PDF, also known as Version of record

\section{Please check the document version of this publication:}

- A submitted manuscript is the version of the article upon submission and before peer-review. There can be important differences between the submitted version and the official published version of record.

People interested in the research are advised to contact the author for the final version of the publication, or visit the DOI to the publisher's website.

- The final author version and the galley proof are versions of the publication after peer review.

- The final published version features the final layout of the paper including the volume, issue and page numbers.

Link to publication

\footnotetext{
General rights rights.

- You may freely distribute the URL identifying the publication in the public portal. please follow below link for the End User Agreement:

www.umlib.nl/taverne-license

Take down policy

If you believe that this document breaches copyright please contact us at:

repository@maastrichtuniversity.nl

providing details and we will investigate your claim.
}

Copyright and moral rights for the publications made accessible in the public portal are retained by the authors and/or other copyright owners and it is a condition of accessing publications that users recognise and abide by the legal requirements associated with these

- Users may download and print one copy of any publication from the public portal for the purpose of private study or research.

- You may not further distribute the material or use it for any profit-making activity or commercial gain

If the publication is distributed under the terms of Article $25 \mathrm{fa}$ of the Dutch Copyright Act, indicated by the "Taverne" license above, 


\section{Active Ownership}

Peter Michael Viehs 


\section{Active Ownership}

(C) Peter Michael Viehs, Maastricht 2013

All rights reserved. No part of this publication may be reproduced, stored in a retrieval system or transmitted, in any form, or by any means, electronic, mechanical, photocopying, recording or otherwise, without the prior permission in writing from the author.

ISBN: 9789461592552

Cover design by Mario Fraikin (www.sinner-graphics.de) with photograph by Peter Michael Viehs.

Printed by: Datawyse | Universitaire Pers Maastricht 


\title{
Active Ownership
}

\author{
DISSERTATION
}

To obtain the degree of doctor at Maastricht University,

on the authority of the Rector Magnificus, Prof. Dr. L.L.G. Soete, in accordance with the decision of the Board of Deans,

to be defended in public

on Wednesday 23 October 2013, at 14.00 hours

by

Peter Michael Viehs

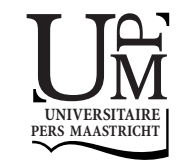




\section{Promoters}

Prof. Dr. Rob M. M. J. Bauer

Prof. Dr. Frank Moers

\section{Assessment Committee}

Prof. Dr. Piet M. A. Eichholtz (chair)

Prof. Dr. Andries de Grip

Prof. Dr. Alexander Kempf (University of Cologne, Germany)

This research has been financially supported by the Graduate School of Business and Economics (GSBE), formerly known as Maastricht School of Economics of Technology and Organization Research (METEOR), The Foundation for Strategic Environmental Research (MISTRA), and The European Centre for Corporate Engagement (ECCE). 
Für meine Eltern 



\section{Contents}

Acknowledgements $\quad$ XI

Chapter 1 Introduction 1

Chapter 2 Industry Competition, Ownership Structure, and 11 Shareholder Engagement

Chapter 3 The Determinants of Withdrawn Shareholder Proposals 45

Chapter 4 The Geography of Shareholder Engagement: 91

Evidence from a Large British Institutional Investor

Chapter 5 The Market for Public and Private Shareholder Engagement 129

$\begin{array}{lll}\text { Chapter } 6 & \text { Conclusion } & 161\end{array}$

Bibliography 169

Deutsche Zusammenfassung (Summary in German) 175

$\begin{array}{ll}\text { Curriculum Vitae } & 185\end{array}$ 


\section{List of tables and figures}

Table 2.1: Proposal topics, average votes and acceptance rates over time ....................25

Table 2.2: Proposals per governance-competition-quadrant......................................27

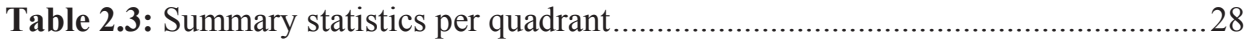

Table 2.4: Determinants of shareholder base........................................................... 30

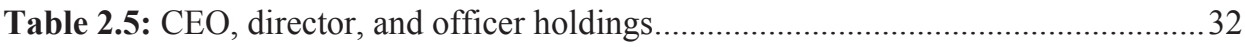

Table 2.6: Determinants for the occurrence of shareholder proposals...........................35

Table 2.7: Determinants of shareholder proposals' voting outcomes ........................... 38

Table 3.1: The evolution of filed and withdrawn proposals ....................................58

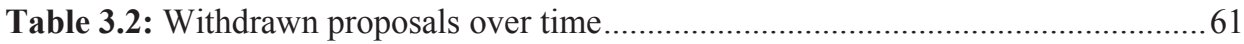

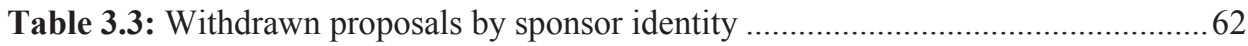

Table 3.4: Withdrawn proposals by sponsorship and coarse subcategories ..................65

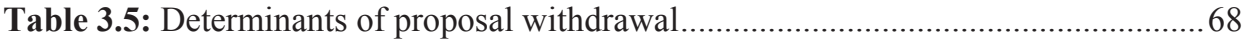

Table 3.6: Determinants of CG proposal withdrawal ............................................... 71

Table 3.7: Determinants of CSR proposal withdrawal .............................................. 73

Table 3.8: Determinants of proposal withdrawal (proposal-level) .............................. 75

Table 3.9: Determinants of CG proposal withdrawal (proposal-level).........................78

Table 3.10: Determinants of CSR proposal withdrawal (prop. level)........................... 80

Table 3.11: The effectiveness of withdrawn proposals (CEO compensation) ...............83

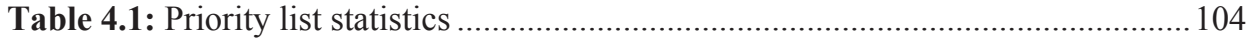

Table 4.2: Temporal and topical scope of engagements and its success ...................... 107

Table 4.3: Geographical dispersion of engagements and milestones ......................... 111

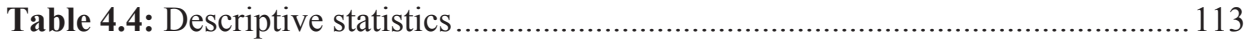

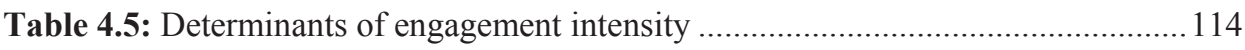

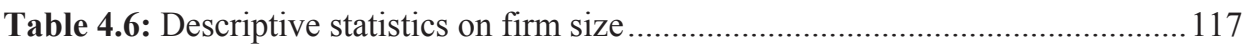

Table 4.7: Determinants of engagement intensity per theme.................................... 119

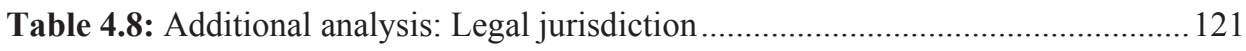

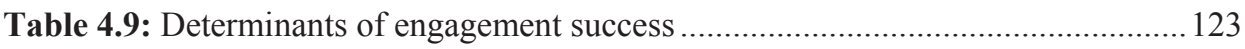

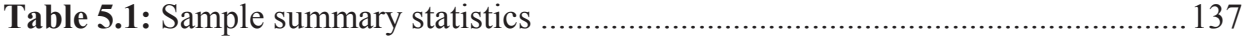


Table 5.2: Sample overview 138

Table 5.3: Temporal evolution of private and public engagements 139

Table 5.4: Evolution of engagement success. 141

Table 5.5: Determinants of targeting 146

Table 5.6: Predicted targeting probabilities 149

Table 5.7: Determinants of targeting (sub-topics) 151

Table 5.8: The determinants of honoring shareholder engagements 153

Table 5.9: Predicted honoring probabilities for any kind of engagement 155

Figure 2.1: Economic Framework 18

Figure 2.2: Number of filed proposals and average voting results over time .23

Figure 3.1: The withdrawal process .52

Figure 3.2: Evolution of withdrawn shareholder proposals 59

Figure 3.3: Withdrawn proposals by proposal content 60

Figure 3.4: Withdrawn proposals split up by sponsor 64 



\section{Acknowledgements}

At the end of 2008, the choice of becoming a doctoral student was far from clear as part of my academic career. After I received my Master's degree in August 2008, I first started as a teaching assistant in the Finance Department of the School of Business and Economics. During this time, I was supposed to teach a course called Institutional Investors. Back then, this was considered - and probably still is - to be the toughest and most challenging course for finance students. The professor who was and still is responsible for this course is Rob Bauer. I had already experienced Professor Bauer the year before, when I took this course as a student. He was also the co-supervisor of my Master's thesis. First, it was a little bit strange to work with (now he became just) Rob on the preparations for his course because I still viewed him as my professor. But because of Rob's mentality and his looseness, I quickly became comfortable working with him. I also started to enjoy our regular discussions about German and Dutch football - not knowing that these are going to be held regularly for the coming four years.

At the end of one of our preparation meetings - as Rob was about to head home - he bluntly asked: "And, by the way, would you be interested in doing your $\mathrm{PhD}$ on a corporate governance topic?" I was not quite sure how to react because I never had thought about doing a PhD, so I hesitated a bit with my answer, and Rob continued: "Just think about it!" A couple of days later, I decided to go for the PhD! Consequently, Rob introduced me to my second supervisor, Frank Moers. Thus, I also then learned that I was going to be (formally) affiliated with both the Finance and the Accounting Departments because Frank was working for the Accounting Department.

In December 2008, right before my PhD contract was going to start, I finally realized that certain routes you take in life have to do with being in the right place at the right time in order to meet the right people. This is exactly how I ended up in my doctoral studies.

Finishing these studies would not have been possible without the help of many people. First and foremost, I would like to thank my first supervisor, Rob Bauer, for his continuous support, his trust, and for his encouragement to pursue my doctoral studies in the first place. Rob, thank you very much. I profited so much from your practical and 
academic knowledge and your leadership skills. In my view, you resemble the perfect $\mathrm{PhD}$ supervisor: On the one hand, you were the chief who always made clear what direction I was supposed to go in. On the other hand, you have been a psychologist, motivator, and friend to me - especially when research was not going the way it was supposed to go. There was not a single meeting we had where I went away with a bad feeling even if the meeting was not that positive. You were always approachable, even on weekends. Okay, you also called me sometimes on Saturdays during important football matches, so I would say we are even! Nevertheless, you gave me all the freedom I needed to further develop the skills that are necessary for completing the $\mathrm{PhD}$ endeavor. You also introduced me into the "real world" of finance practitioners and showed me that our academic research is also of value to the financial world outside the universities. Rob, thank you very much for everything you made possible.

I am equally deeply indebted to my second supervisor, Frank Moers. Frank, many thanks for our numerous discussions on our papers and all the help and encouragement you provided me with over the years. Whenever I had a problem with my research, you always had an open door and listened to me. I profited tremendously from your incredible knowledge and your experience as a passionate researcher. Thank you very much for all of your critical questions that prepared me so well for my future career.

I thank my assessment committee consisting of Piet Eichholtz, Andries de Grip, and Alexander Kempf for their quick feedback and constructive comments on my dissertation manuscript.

I am also very thankful to Gordon Clark who made it possible for me to stay at the University of Oxford for an exchange semester. Gordon, many thanks for your kind hospitality and I am looking forward to future projects together. Thanks are also directed to Amanda, Dane, Darek, Heather, and Sarah who made my stay in Oxford a wonderful experience and a very productive one.

Similarly, I thank all the people who made my research projects on the engagement activities of a large institutional investor possible: Karina Litvack, Sagarika Chatterjee, Sandra Carlisle, Saskia van den Dool, and Shelley Keep. Without your help, the latter two empirical chapters of this dissertation would have not been realized.

Special thanks are also devoted to the prototypes of good teachers: Stefanie Kleimeier and Rob Bauer. From you two, I have learned how to teach in a strict, but fair and friendly way. It was always a pleasure to work with both of you in your courses. I also thank you Stefanie for introducing me to the art of networking at academic conferences ("let's mingle!") and for sharing your wide range of research experiences. It was always great fun to travel together to conferences and to go sightseeing.

I also want to thank Nadja Guenster, Jaap Bos, and Jeroen Derwall for numerous discussions about research projects and related things, and for convincing me to stay in the academic arena; Nils Kok for inspiring me about the potential that academic research can have; and Paulo Rodrigues and Stefan Straetmans for countless football discussions. Gildas, thanks a lot for our long talks and for all your help and support in the later stages of my studies. I wish you all the best for finishing "your piece"! Many thanks are also directed to Aleks and Lei: I enjoyed our common time as PhD students. You are great 
friends. Thanks for our numerous talks, discussions, and many funny moments! I wish you both all the best for your futures.

I am also grateful to all my colleagues in the Finance Department: Andrea, Anna, Arvid, Carl, David, Dennis, Gaby, George, Harry, Joost, Katie, Leonard, Matteo, Mukul, Oana, Omar, Peter, Patrick, Paul, Rachel, Roger, Rogier Holtermans, Rogier Quadvlieg, Sally, Simone, Sjoke, Stefan, and Thomas. I am also grateful to my former PhD colleagues: Anant, Erkan, Johannes, Mona, Sajid, and Sebastian. In particular, I thank Daniel and Julius for their company during the initial phases of the $\mathrm{PhD}$, and of course Robin, from whom I learned how to make the first steps in academic research.

A big "thank you" also to the "ladies from the secretariat": Carina, Cécile, Els, and Francien. Thank you very much for your help in all situations. Especially in the process of finishing this dissertation, you became indispensable to me. Any boss would be happy to have secretaries like you. And please accept my apologies for destroying your stapler...

Wie es bereits zur Tradition geworden ist, möchte ich den wichtigsten Menschen in meinem Leben zum Schluss danken. Allen voran danke ich meinen Eltern und meinem Bruder Florian. Liebe Mama, lieber Papa: Diese wenigen Zeilen reichen niemals aus, um mich bei Euch für all das zu bedanken, was Ihr für mich getan habt. Aber eines weiß ich mit Sicherheit: Ohne Eure stetige Unterstützung, Eure Hilfe und guten Zuspruch hätte ich das Unternehmen „Doktor“ womöglich nie abgeschlossen. Danke, dass Ihr immer an mich geglaubt habt. Danke für die Unterstützung bei den ersten Schritten in Maastricht vor nunmehr neun Jahren, bei den zahlreichen gewollten oder weniger gewollten Umzügen, und für Eure Geduld mit mir in schwierigen Situationen. Ich denke, dass nicht nur mich die letzten viereinhalb Jahre einiges an Nerven gekostet haben, sondern auch Euch. Alles, was ich erreicht habe, habe ich Euch zu verdanken und wäre niemals ohne Euch möglich gewesen: Vielen Dank.

Lieber Florian, Du warst immer eine große Stütze für mich und hast mir immer sehr geholfen. Du warst bei allem dabei, und hast alles mitgemacht, was diese Arbeit betrifft. Dir wünsche ich alles Gute für Deinen weiteren beruflichen und privaten Werdegang. Es ist schön, einen Bruder wie Dich zu haben.

Vielen Dank sage ich auch Oma Adelheid und Opa Heinz sowie Oma Marianne und Opa Josef. Ich bin sehr froh darüber, dass Ihr miterleben könnt, wie ich diesen Lebensabschnitt abschließe.

Ein großer Dank ist auch gerichtet an alle Freunde in meiner Heimat Kreuzau. Vielen Dank an das „Clübsche“ bestehend aus Alex, Arne, Basti, David, Jenny, Jonny, Manu, Mathias, Thomas, Timo, Pascal, und Paul für unvergessliche Abende und interessierte Nachfragen. Durch Euch ist mir bewusst geworden, was Freundschaft und Heimat bedeutet.

Dank gilt auch den Aachenern bestehend aus Katja und Thomas, Selina und Mario, sowie Paul für viele schöne Abende und viel Spaß - vor allem bei bis zur letzten Minute spannenden Fußballspielen. Besonderer Dank gilt meinem langjährigen Freund Mario, der mir auch bei der grafischen Gestaltung dieser Dissertation behilflich war. Vielen Dank, Mario, auch für Dein immer offenes Ohr und Deine Freundschaft. 
Ein ganz besonderer Dank gilt Jasmin. Jasmin, Du hast mir gezeigt, was wichtig im Leben ist. Du warst immer für mich da, hast mich unterstützt, und mir jederzeit zugehört. Danke, dass Du Träume mit mir leben willst. Ich bin unglaublich froh, dass wir uns gefunden haben!

Schlussendlich kann ich nach viereinhalb Jahren Doktoranden-Daseins guten Gewissens behaupten, dass die ersten drei Artikel des „Kölschen Grundgesetzes“ den Weg eines Doktoranden am besten beschreiben:

\section{Et es wie et es.}

Et kütt wie et kütt.

Et hätt noch emmer joot jejange.

Aachen, August 2013

Peter Michael Viehs 


\section{CHAPTER 1 Introduction}

The fundamental characteristic of the modern corporation is the separation of ownership and control. In their influential work, Berle and Means (1932) were the first to introduce this idea by recognizing that the ultimate owners of the corporations, the shareholders, delegate their management tasks to agents - the managers. Conceptually, the shareholders of publicly listed corporations hire the managers to run the corporation in their interest. However, the separation of ownership and control gives rise to principal-agent conflicts between the managers (agents) and the shareholders (principals), that is, the managers do not act in the best interest of the shareholders. Jensen and Meckling (1976) formally show that these agency conflicts can lead to agency costs of equity: The managers are likely to entrench themselves or to pursue the maximization of their private benefits without taking into account the shareholders' interests.

To circumvent these agency conflicts that impede the value creation for shareholders, the corporation can install certain corporate governance mechanisms. These mechanisms should attenuate the managerial entrenchment by aligning the interests of the managers and the shareholders. In my view, Shleifer and Vishny (1997) provide the most appropriate definition of corporate governance: "Corporate governance deals with the ways in which suppliers of finance to corporations assure themselves of getting a return on their investment" (p. 737). Hence, corporate governance refers to all of the mechanisms and instruments in place that control managerial actions. These mechanisms should ensure the proper management of the corporations in the shareholders' interests that in the end should ensure the returns on the shareholders' investments.

The corporate finance literature provides many examples of corporate governance mechanisms. The most direct governing body in publicly listed corporations is the board of directors or the supervisory board. The board of directors should monitor the corporate executives on behalf of the shareholders. Fama and Jensen (1983) argue that the existence of an efficiently working board of directors limits managerial entrenchment. Additionally, the literature emphasizes the importance of the corporation's ownership 
structure (e.g., Shleifer and Vishny, 1997), executive compensation and incentive packages (e.g., Jensen and Murphy, 1990), and capital structure (e.g., Berger, Ofek, and Yermack, 1997) as corporate governance mechanisms. One important external corporate governance tool, especially in the Anglo-Saxon countries, is the market for corporate control, or the managerial labor market. The literature argues that the corporations that are exposed to a potential takeover threat are more efficiently managed (Gompers, Ishii, and Metrick, 2003). More recently, the corporate governance literature has stressed the importance of the product market as a governance tool (Giroud and Mueller, 2011). ${ }^{1}$

Aside from these indirect monitoring tools, shareholders - as the ultimate owners of the corporation-also have a very explicit corporate governance tool at their disposal, namely direct interventions. My dissertation focuses on these direct interventions as an important corporate governance mechanism. In particular, I study shareholder engagement practices that aim at improving corporate environmental, social, and governance (ESG) policies that ultimately translate into shareholder value creation. Tirole (2006) defines these practices as "active monitoring" that involve "interfering with management in order to increase the value of the investors' claims" (p. 27).

At this stage, how I define shareholder engagement in this dissertation is important. Conceptually, I allege that shareholder engagement describes all of the actions that the shareholders could undertake to promote changes in corporations. These actions can range from class-action lawsuits, over aggressive stake acquisitions by hedge funds, to the launching of media campaigns. In its most basic form, shareholder engagement occurs on an annual basis during the annual general meeting (AGM) of the corporations through proxy voting. At every AGM, the shareholders are asked to vote on particular issues like board composition, executive compensation policies, or the introduction of new governance standards. Generally, all of the major shareholders, like insurance companies, asset managers, and other institutional investors, participate in the proxy voting but also the small, retail investors who just hold a couple of shares are eligible to participate.

However, shareholders can even go beyond mere proxy voting and do more in order to bring about change. Shareholders themselves can file shareholder proposals (or resolutions) that are put on the voting agenda of the AGM. In doing so, they can determine parts of the voting agenda and can communicate their requests to a wider shareholder audience. I consider the filing of shareholder proposals as another shareholder engagement strategy. Furthermore, I believe that the filing of proposals can be especially important to institutional investors who have the fiduciary duty to act according to their beneficiaries' investment guidelines and beliefs. Another increasingly important engagement tool are private dialogues and management meetings, especially for institutional investors. These private negotiations generally take place behind closed doors between large institutional investors and the management. Using these private negotia-

\footnotetext{
${ }^{1}$ A very detailed discussion of all of the available governance mechanisms is beyond the scope of the introduction of such a dissertation. For a more detailed discussion of the variety of potential governance mechanisms, see for example Becht, Bolton and Röell (2003), and Shleifer and Vishny (1997).
} 
tions, institutional shareholders can directly communicate and discuss their concerns and suggestions with the management. An interesting feature of private engagements is the fact that they are generally not observable by other shareholders and that they always occur in the shadow of a potential filing of a shareholder proposal.

These different shareholder engagement practices - the proxy voting, filing of shareholder proposals, and the private negotiations - constitute examples of the voice dimension of Hirschman's (1970) exit, voice, and loyalty continuum. Hirschman postulates that dissatisfied customers of a company can express their discontent through three different channels. First, customers can simply continue buying the product and do nothing. In doing so, they express loyalty towards the company. Second, customers can go to another producer of the same product (if available) and thereby cease buying from the inferior producer. Hirschman calls this the exit option. Third, customers can communicate their discontent to the producer of the product and in doing so, try to promote a change in the corporation using their voice (Hirschman, 1970, p. 4). I compare Hirschman's concept to a situation where shareholders are not satisfied with either the corporation's performance or its practices. I do so by studying shareholder engagement practices in the form of filing and withdrawing shareholder proposals, proxy voting, and private negotiations, which are all varieties of Hirschman's voice dimension. Hence, in this dissertation, I study the voice engagement of shareholders.

However, in the context of my dissertation, shareholder engagement is more than just expressing one's discontent with corporate performance and managerial actions. I argue that the shareholder engagement has another facet that amplifies its importance in today's capital markets. Specifically, I consider the shareholder engagement as a way to invest responsibly and sustainably by trying to improve corporate ESG policies. Increasingly, the clients and the beneficiaries of large institutional investors are scrutinizing where and how the returns on their investments are generated. Often, the beneficiaries request that their investment returns come from sustainable and responsible investments. Further, retail investors also tend to be more and more selective when making investment decisions. However, is just investing in sustainable businesses actually responsible if the 'irresponsible' ones are left aside? I claim that the answer to this question is no. In this dissertation, I argue that shareholder engagement should be used especially by, but not exclusively by, large institutional investors who have the economic power to promote changes at corporations in order to make them more responsible and sustainable. By raising their voice, they can "invest for change" (Landier and Nair, 2009) and not by simply using the exit option.

In the wake of the financial crisis of 2008 and the current European debt crisis, the topic of this dissertation could not be more up to date. Governments, politicians, and also major parts of the society are asking for higher levels of shareholder involvement in the decision-making process of large corporations. In the most recent discussions, most of the emphasis is on the shareholders' voting and engagement on executive pay packages. A prominent example of this public outrage is the Swiss initiative against excessive executive pay practices (Abzocker-Initiative). The majority of Swiss voters supported this initiative in a referendum in early March 2013. The positive voting outcome for this referendum implies that publicly listed corporations in Switzerland are now exposed to a 
binding shareholder vote on executive pay. In other words, the shareholders now decide the structure and level of executive pay. This dissertation does not directly take a stance on binding shareholder votes on executive pay. Rather, my dissertation sheds more light on the level and the effectiveness of the shareholder engagements. Thereby, I contribute to the more general discussion on shareholder engagement in the sense that I not only investigate the engagement concerning executive pay practices but also other corporate issues like corporate governance structures, corporate human rights policies, worker safety standards, corporate environmental policies, and so forth. With my work, I also show that shareholder engagement has gone on for quite some time, even before politically imposed regulations on the shareholders' involvement were introduced.

In the remainder of this introduction, I briefly sketch the contents of the different chapters and provide a brief summary of the key findings, followed by a more detailed discussion of each of the chapters. The first part of my dissertation (Chapters 2 and 3) focuses on the public shareholder engagement in US corporations. In particular, I provide evidence on the shareholder proposals that are quite frequently used by shareholders in the United States to express their concerns about particular corporate policies. I consider the shareholder proposals to be part of the public shareholder engagement universe, that is, these engagements are publicly observable by other shareholders and market participants. In Chapter 2, I investigate the determinants of the occurrences of the shareholder proposals in US corporations and their corresponding voting outcomes at the AGMs. I provide answers to the questions on which corporations become targeted by the shareholder proposals and what determines the voting outcomes of these proposals. Then, in Chapter 3, I research in more detail the substantial number of the shareholder proposals that get voluntarily withdrawn by the sponsoring shareholder prior to the AGM every year. Hence, I investigate what leads shareholders to withdraw their proposals. Apparently, a specific private and confidential facet within the public shareholder engagement universe makes these shareholders withdraw their public proposals. I conjecture in Chapter 3 that withdrawn proposals are the strongest kind of shareholder proposals that exist in the United States.

In the second part of my dissertation (Chapters 4 and 5), I turn to an analysis of the private shareholder engagements. Contrary to the public shareholder engagements, the private engagements are not observable and take place behind closed doors between the shareholders and the corporations. The private engagements are usually management meetings, telephone calls, letter writing, or direct private dialogues between the equity holders and the corporations. These kinds of engagements are generally undertaken by the larger institutional investors who have the economic power and the resources to effectively engage the corporations on a bilateral basis. In Chapter 4, I examine the private engagement activities of a large UK-based institutional investor who also provides engagement services to institutional clients. Using a proprietary data set on its global engagement activities, I study the evolution of the investor's private engagements over time and which corporations from which geographical regions are most likely to be targeted by the investor. Additionally, I investigate the determinants of the private engagement's success in this Chapter. Having studied both private and public shareholder engagements separately (Chapters 2-4), Chapter 5 includes both engagement means in the 
analysis. That is, I study the simultaneous presence of private and public engagements, the presence of both engagement means in a corporation's recent history, and a corporation's history of successful engagements to shed light on the question of how both interact. My goal is to show in Chapter 5 that the shareholder engagements take place through observable and visible means, like shareholder proposals; but that a substantial fraction of the engagements take place through private means, like dialogues between institutional investors and corporations. We, as researchers, should not neglect the private facet of the shareholder engagement because its presence ultimately affects the presence and the effectiveness of the public shareholder engagement and vice versa.

Having written four extensive chapters on the topic of shareholder engagement and active ownership, I conclude the following. Shareholders, as the ultimate owners of corporations and important capital providers, have the responsibility to monitor managerial actions and corporate behavior as the most important stakeholder group. In doing so, the shareholders can hold their managers accountable and responsible for their actions and can promote more sustainable behavior in the corporate world. My results indicate that shareholder engagement was already present more than ten years ago and that today a lot of engagement is performed, especially by institutional investors. However, I claim that there is much more possible that is legally allowed in terms of the shareholder collaboration and coordination of engagement efforts. Taking into account the growing demand for sustainable investments, the institutional investors should use engagement as a way to invest responsibly. I aver that the shareholders should not wait for politics to impose regulations and restrictions on certain corporate policies, but that shareholders should proactively raise their voice to promote corporations to be more sustainable and responsible.

\subsection{Industry competition, ownership structure, and shareholder engagement}

Chapter 2 of this dissertation studies the occurrence of shareholder proposals and the corresponding voting outcomes when two other important corporate governance mechanisms are absent: The market for corporate control and product market competition. This chapter focuses on voted proposals and studies whether the shareholder proposal mechanism can act as a substitute for other corporate governance mechanisms. My main research hypothesis is that the simultaneous absence of product market competition and the market for corporate control significantly increases the likelihood of corporations becoming targets of the shareholder proposals. Using data on shareholder proposals from 1997-2006 at S\&P1500 corporations, my results support this hypothesis. These results are distinctive from those of the other studies on shareholder proposals because I take all of the filed shareholder proposals into account when modeling the targeting likelihood. That is, in the analysis I also incorporate those proposals that were omitted and withdrawn prior to the AGM, because they essentially were filed and the corporation is liter- 
ally exposed to the proposals. Hence, my results are more robust compared to the other studies conducting similar analyses.

Regarding the determinants of the voting outcomes, I find that the proposals receive fewer votes when they are large and when they have a high concentration of equity ownership within the board. I argue that the negative effect of the equity concentration in the board reflects the fact that the board members are voting against the shareholder proposals and in doing so, are suppressing the voting outcomes of those proposals. This result is especially pronounced in poorly governed corporations. Chapter 2 also reflects the importance of shareholder proposals as a governance mechanism: the number of filed proposals increases over time, and the institutional investors more and more frequently use the proposals as a monitoring device.

\subsection{The determinants of withdrawn shareholder proposals}

In Chapter 3, I present evidence on a specific subset of shareholder proposals, namely withdrawn proposals. The withdrawn proposals occur when shareholders voluntarily withdraw their filed proposal before the actual AGM takes place. Consequently, no vote is held on the particular issue specified in the withdrawn proposal. How do withdrawals of the shareholder proposals occur?

Usually, shareholders file proposals to have a vote on a particular issue during the AGM. However, the mere filing of such a proposal does not necessarily lead to a ballot at the AGM. In the run up to the AGM, the corporations collect all of the filed shareholder proposals, and the corporation has three options for each of these proposals: First, the management simply lets the proposal go to a vote during the AGM. Second, based on the contents of the shareholder proposal, the management team can ask the SEC for an official exclusion from the proxy materials due to a violation of the rules and regulations contained in the SEC's rule $14 \mathrm{a}-8$ on shareholder proposals. If the SEC permits the exclusion of the proposal, it becomes omitted from the proxy materials and no vote is held. Third, the management team can invite the sponsors of the particular proposals into private negotiations on a withdrawal. I conjecture that these negotiations mostly happen for those proposals that could create negative publicity for managers, or those proposals that are the most adverse to managers such as eroding managerial power or cutting executive compensation. If the private negotiations yield a satisfactory compromise for the shareholder, he or she can then voluntarily withdraw the proposal before the AGM takes place. A compromise can be a partial or even a full implementation of the requests specified in the proposal. Therefore, a withdrawn proposal represents in my eyes a successful negotiation and thus a successful shareholder engagement. This argumentation is consistent with Landier and Nair (2009) who argue that withdrawn shareholder proposals represent managers implementing the shareholders' requests. In case no compromise is reached, the proposal is not withdrawn, and a vote is held during the AGM.

The corporate governance literature has widely neglected withdrawn shareholder proposals. Except for Carleton, Nelson and Weisbach (1998) and Chidambaran and 
Woidtke (1999), no other studies explicitly investigate withdrawn shareholder proposals. I hypothesize in Chapter 3 that more powerful shareholders (in terms of stockholdings) are more likely to reach an amicable compromise with managers and that the likelihood of withdrawal is positively related to the ownership stake of the institutional investors in general. My results confirm these hypotheses. I find that the proposals filed by the institutional investors are the most likely to be withdrawn. Furthermore, I show that the ownership stake of the institutional investors is also positively related to the likelihood of withdrawal. My results indicate that in particular, the ownership stake of quasi-indexer institutions drive this effect. The proposal-level analysis in Chapter 3 also shows that insider ownership - as measured by CEO ownership - is significantly and negatively related to the likelihood of withdrawal, which indicates the bargaining power of the managers. My results also point to a cross-sectional difference between the corporate governance and the corporate social responsibility proposals.

Overall, Chapter 3 has important implications for managers and shareholders. The mere proxy voting and the filing of proposals are not what only matters in the entire public shareholder engagement process, what also matters are the private negotiations between the shareholders and the managers. Otherwise, one would not observe approximately $20 \%$ of all filed proposals being withdrawn every proxy season. Chapter 3 provides the first indicative evidence that private dialogues and negotiations could serve as important engagement devices for shareholders. How exactly this works in practice is investigated in the next chapter.

\subsection{The geography of shareholder engagement}

In Chapter 4, I turn away from the public tactics of shareholder engagement to the private engagement strategies that the institutional investors adopt to promote changes at portfolio corporations. Specifically, I investigate the private engagement activities of a large UK institutional investor. Private engagements can be defined as bilateral talks, discussions, and personal meetings between the institutional investors and the managers of investee firms. Similar to public engagements, these private engagements are undertaken in order to change the corporate governance structure or the corporate social and environmental practices. However, this private engagement route is a more direct engagement tool because the institutional investor has immediate contact with the corporation and its management team. McCahery, Sautner, and Starks (2013) show that the institutional investors use private engagements as one of their major tactics to influence the managerial and in turn corporate behavior.

Using proprietary information from a large UK-based institutional investor on its global engagement activities, I pose the following research question: Which corporations from which geographical regions are most prone towards the private engagements and for which corporations are these private engagements most likely to be successful?

I hypothesize that a home bias exists in the context of private engagements. Specifically, I conjecture that portfolio corporations that are not domiciled in the United King- 
dom are significantly less likely to receive engagements from the institutional investor. The underlying drivers of this hypothesized relation are the higher information asymmetries and transaction costs when a UK-based investor wants to engage with foreign corporations. Furthermore, I posit that the foreign corporations located in very distant capital markets also display significantly less successful private engagements for similar reasons.

My results indeed indicate that there is a home bias in the private engagements. The corporations based in the United Kingdom receive significantly more engagements than their foreign counterparts. Additionally, I show that the larger corporations also get more engagements than the smaller corporations. Importantly, I find an important momentum effect in private engagements: the number of private engagements in the previous year significantly increases the intensity of the corporate engagements in the current year. On average, corporations from the United States and Continental Europe display significantly more successful private engagements than UK corporations. The UK and Japanese corporations, on the other hand, have relatively higher success ratios with respect to engagements related to social issues.

Chapter 4 indicates that institutional investors are important players in the shareholder engagement process. Even though my results are based on the private engagements of a single UK-based institutional investor, I can conclude that the private engagements of institutional investors are just as important a force as the public and observable engagement tactics like shareholder proposals. Importantly, these engagement activities do not exclusively strive for corporate changes regarding the governance structure of the corporations. Rather, I find that the institutional investor is also very keen on changing the corporate social and environmental policies such as respecting human rights, worker safety standards, or limiting environmental pollution.

\subsection{The market for public and private shareholder engagement}

While Chapters 2 through 4 focus on either public or private shareholder engagements, Chapter 5 adopts a more holistic approach towards shareholder engagement. In this chapter, I provide the first indicative evidence on the interplay between public and private shareholder engagements in promoting corporate changes with regard to environmental, social or governance issues. I show how public and private engagements evolve over time, which kind is the most effective, and which corporations are the most likely to be exposed to some type of engagement. Also, I show which corporations are the most likely to settle with the shareholders, that is, how likely the corporations are to change in response to certain shareholder engagements.

The most important contribution of this chapter to the corporate governance literature is the fact that I study both the public and the private side of shareholder engagement at the same time. More precisely, I combine the research strands of corporate engagement presented in the first part of this dissertation (Chapters 2 and 3) with the evidence provided on private engagement activities of institutional investors (Chapter 4). 
This is important because the literature discusses the public and the private shareholder engagements separately without taking into account the important interdependencies between the two means of engagement.

Chapter 5 relies on similar data sets as the chapters before. I also make use of the data on the public shareholder proposals of all of the S\&P1500 corporations and merge these data with the proprietary database on the private engagements of the UK-based institutional investor. The time period under investigation for the common sample is 1999-2011. The first part of this chapter is concerned with the evolution of private and public engagements. My descriptive results indicate that over time, the number of corporations exposed to the private or the public, or even both types of engagement, rises over time. However, it is important to note that on average more than half of the observations display neither the public nor the private engagements. Furthermore, I find that on average the corporations exposed to the shareholder engagements receive more private than public engagements. Regarding successful engagements, my results show that the public engagements are more successful than the private engagements.

The second and empirical part of Chapter 5 deals with the targeting and success likelihoods. I find that corporations are significantly more likely to be targeted with some type of engagement in the current year after being exposed to both the private and the public engagements in the previous year. This result implies that a particular type of corporation is targeted with both the public and the private engagements over and over again. One reason for this finding for example could be that these corporations are per se also the corporations that are most responsive to shareholder engagements.

With respect to the success of shareholder engagements, the results of Chapter 5 indicate that those corporations that have the highest predicted honoring likelihood have current public engagements, no public engagements in the previous year, and have had many honored public engagements in the previous year. A high exposure of those corporations towards private engagements (irrespective of the time period) increases the honoring likelihood even further. The results also indicate slight differences for different subsamples of engagements.

Overall, Chapter 5 of my dissertation illustrates that the shareholder engagement indeed consists of a public and a private domain and that both of them are significant drivers of the success for any kind of engagement. Therefore, Chapter 5 has important implications for institutional investors who like to engage with investee corporations on certain corporate issues. They have to consider the engagements that are and have been going on at the corporations before starting the actual engagement in order to increase the odds of being successful.

The following four chapters shed light on shareholder engagement as a corporate governance tool in more detail. The last chapter of my dissertation (Chapter 6) summarizes this dissertation and provides the reader with the implications for managers, investors, and researchers. 



\section{CHAPTER 2 \\ Industry Competition, Ownership Structure, and Shareholder Engagement ${ }^{2}$}

In this chapter, I study shareholder engagement through proxy proposals in the United States from 1997-2006. I investigate the determinants for being targeted by these proposals and the corresponding voting results. By using a distinctive sample that also includes withdrawn and omitted proposals, I circumvent a selection bias towards those proposals that actually go to a vote. I hypothesize that a lack of industry competition in combination with higher managerial entrenchment increases the likelihood of being targeted. My empirical results support this hypothesis. Concerning voting outcomes, I find that insiders' equity holdings have a significant and negative correlation. Hence, managers actively vote against shareholder proposals.

\footnotetext{
${ }^{2}$ This chapter is based on Bauer, Braun, and Viehs (2012). I thank Alex Edmans for his generous comments, which greatly improved the chapter. I am thankful to Andriy Bodnaruk, Stuart Gillan, Julian Franks, James Hawley, Tessa Hebb, Kose John, and Frank Moers for helpful advice.
} 
CHAPTER 2 


\subsection{Introduction}

In this chapter, I demonstrate that managerial entrenchment and the corporation's exposure to industry competition jointly influence the occurrence and efficiency of shareholder engagement in the form of proxy proposals. Using this channel, shareholders can monitor and pressure the management and the board to pursue actions that increase shareholder value. The filing of shareholder proposals is an important corporate governance mechanism in the United States. Rule 14a-8 of the Securities Exchange Act of 1934, the so-called shareholder proposal rule, allows shareholders to file proposals to be included in the proxy statements that strive for changes in the corporations' operations, governance structures, and social policies. I hypothesize that corporations with low competition and poor governance are more likely to be targeted by shareholders. Concerning the success rate of the voting process, the roles of the outside shareholder base and the insider holdings of voting rights are pivotal. This chapter does not only investigate the magnitude and frequency but also the actual outcome of the shareholder proposals.

Over the last decade, both small individual shareholders, so-called gadfly investors, and institutional shareholders have become more active in trying to influence and change managerial actions and corporate governance structures. Examples from the 2008 proxy season are Carl Icahn and his confrontational request to remove the entire board of directors of Yahoo!, the Rockefeller family who strived for the separation of the positions of the chairman of the board and the CEO at Exxon Mobil, and the CalPERS' shareholder proposal asking for the declassification of Standard Pacific's Board of Directors.

Managers are exposed to several monitoring mechanisms. First, the managerial labor market is designed to ensure that they maximize the corporation's value. The extent to which managers are exposed to takeover threats and the accompanying shareholder wealth effects is widely researched in the literature (e.g., Gompers, Ishii, and Metrick, 2003). Second, the degree of industry competition can extend monitoring because it acts as an alternative or complimentary corporate governance mechanism in motivating and disciplining managers to exert optimal effort (e.g., Hart, 1983; Giroud and Mueller, 2010, 2011). The industry competition as a governance device makes economic sense because competition in the industry reduces managerial slack and the room for opportunistic behavior. Therefore, I assume that the threat of being driven out of business is equivalent to being taken over. Both eventually result in the manager's position being endangered. The industry competition as a purely exogenous governance mechanism cannot be altered by shareholders. This fact implies that the shareholder engagement is more likely to occur in industries in which the corporation competes with very few companies for market share. I define competition as the Herfindahl-Hirschman Index (sum of each corporations' squared percentages of the industry's total revenue; henceforth HHI) corresponding to the 3 -digit SIC code.

I posit that if both industry competition and the managerial labor market fail to discipline managers, then the shareholders will adopt a different way of trying to influence managerial behavior and the corporate governance structures, namely voice engagement 
through shareholder proposals. By raising their voice, shareholders can prevent managers from enjoying a quiet life, a concept that Bertrand and Mullainathan (2003) put forward. In this chapter, I assume that just dealing with the mere filing of the shareholder proposals is costly for managers. On the one hand, this is because of the negative publicity. For the manager, filing is a public signal of underperformance. On the other hand, the filing also resembles a significant opportunity cost for the managers who actively try to block the proposals. This costliness also siphons resources and time from the agenda of the annual general meeting. The siphoning makes shareholder engagement a pervasive nuisance for the entrenched manager. I argue that the occurrence of shareholder proposals is particularly strong for poorly governed corporations that are not exposed to fierce industry competition and the managerial takeover market. In the absence of punishment for poor performance, the shareholders' optimal response in these corporations is to propose steeper incentives for managers. Figuratively speaking, the absence of sticks requires the managers to be awarded carrots in order to exert optimal effort. However, the carrots in the form of option packages involve the downside of equity compensation. As a result, the corporate insiders might then own a larger fraction of voting rights that could be abused to enforce certain corporate policies that are not in the interest of the shareholders. Consequently, I also investigate how much the insiders' voting rights influence the voting outcomes of the shareholder proposals. Specifically, I study whether the managers use their voting rights to vote against shareholder proposals.

I start by showing who gets targeted. I observe an increasing trend in aggregate in the shareholder proposals between 1997 and 2006. Corporations are more likely to receive shareholder proposals if they are both poorly governed and if the disciplining force of a highly competitive industry is absent. This finding is particularly strong for the shareholder proposals that pertain to internal governance and compensation, which is in line with the shareholders' optimal response. The outside shareholder base and its structure play a significant role with respect to the occurrence and frequency of the shareholder proposals.

Next, I look at what determines the success of the engagement. In particular, I look at the effects of insider and institutional ownership. My analysis shows that the voting outcomes of the shareholder proposals have a stronger correlation with the shareholdings of corporate insiders than they have with the holdings of outside investors. Therefore, the corporate insiders use their voting rights to block shareholder proposals when both the shareholders' rights and the industry competition are absent. I find a significantly negative relation between my measure for the insider ownership and the number of votes cast in favor of the proposals. This result is robust to different measures of competition and governance quality. These findings indicate that the managers in these corporations are not able to shirk because the corporate insiders receive negative publicity from the engagement and have to actively vote against the proposals. This finding holds especially in the presence of steeper incentives. I argue that the shareholders of poorly governed corporations recognize that the managers of these corporations have more discretion, and thus shareholders use voice engagement in the form of their proposals to discipline and monitor the managers. 
My results have several implications. If corporate insiders actively vote to block the shareholder proposals, then my results help to explain why previous studies find that the proxy proposal mechanism is ineffective in monitoring managers. The results of my empirical analysis ultimately relate to two different streams in the literature: shareholder engagement and industry competition as alternative or complimentary corporate governance mechanisms. To the best of my knowledge, no previous study explicitly investigates the impact of the industry competition in combination with the managerial entrenchment on the presence and the effectiveness of the shareholder engagement. So far, the literature on shareholder engagement mainly focuses on corporate and ownership characteristics to draw inferences about the determinants of the likelihood of receiving a proposal and the corresponding voting results. In particular, the insider and outsider shareholder base influences the voting results of the shareholder proposals (Gordon and Pound, 1993; John and Klein, 1995; and Gillan and Starks, 2000). Furthermore, the chances of being targeted by the proposals are affected by the corporation's past performance and its size (John and Klein, 1995; Karpoff, Malatesta, and Walkling, 1996). The previous studies find no significant relation between the insider holdings of voting rights and the likelihood of receiving a proposal.

The institutional shareholders play an important role in the proposal process, both as proposal sponsors and as shareholders per se (Smith, 1996; Wahal, 1996; Kahn and Winton, 1998; Gillan and Starks, 2000). These investors have more incentives and power to induce other (institutional) shareholders to vote with them. Consequently, the proposals sponsored by institutions display the strongest voting support. They are also more effective in possible private negotiations with management that might eventually lead to changes in the corporate policies or the governance structures (Carleton, Nelson, and Weisbach, 1998; Chidambaran and Woidtke, 1999). This is especially true for the proposals that are withdrawn prior to the annual meeting. These proposals provide evidence of the bargaining power of the institutional investors and/or the management in private negotiations. Withdrawn proposals also reflect the managers' ability to shirk because they will negotiate about a possible withdrawal if they feel that the proposals erode their managerial power or expose them to negative publicity. Given that the managers are able to successfully negotiate a proposal withdrawal, they are in a comfortable position. Omitting these proposals from the analysis causes a serious bias towards ex post unsuccessful proposals, which I address.

An emerging body of literature questions the absolute measure of corporate governance and proposes the addition of a moderating factor into the analysis, namely the degree of industry competition. The theoretical work by Hart (1983) provides the foundation for the argument that the industry competition can mitigate the principal-agent conflicts. The key idea in this concept is that good governance only matters relative to the industry or the geographic peers. Giroud and Mueller (2010) report that highly concentrated industries benefit from good corporate governance practices whereas in competitive industries this effect is not observable. Likewise, Giroud and Mueller (2011) show that, on average, the corporations in highly concentrated industries suffer from exogenous shocks that weaken their governance structures. In contrast, the corporations in highly competitive industries are not affected by these shocks. Further, they find that the 
managers of corporations in highly concentrated industries enjoy a quiet life. Lastly, a corporation's governance quality has to be evaluated against its operating environment (John and Kadyrzhanova, 2008). Ultimately, the evidence on industry competition as a governance mechanism alludes to a relation between the level of competition and the corporations' governance quality. I provide direct evidence on the relative governance by showing that managers of poorly governed corporations in highly concentrated industries are prevented from exerting little effort because the shareholders become active and exert control. I show that only if the managers hold substantial fractions of the voting rights, and if they use those rights to vote against the shareholder proposals, then they are in a dominant position. A logical reaction is to exploit the voting rights in management proposals. However, the shareholders are still able to attach negative publicity to their engagement, which is what the managers aim to avoid.

This chapter contributes to the literature on shareholder engagement in several ways. I start by examining the determinants of being targeted by shareholder proposals. Here, I contribute by studying the joint effects of the industry competition and the managerial labor market (i.e., antitakeover provisions) on the occurrence of proposals. Moreover, I contribute by studying under which circumstances corporate insiders are in a comfortable position when the disciplining forces from the takeover market and industry are absent. To shed light on this hypothesis, I study if insider holdings of voting rights are used to block the shareholder proposals that eventually go to a vote at annual general meetings. If these holdings significantly relate to the voting outcome, then I provide indicative evidence that the managers actively vote against the shareholder proposals. However, if the shareholders succeed at the AGMs with their proposals, then I find evidence of optimal contracting; and the managers are still controlled. I therefore provide evidence on the efficiency of the shareholder engagement in the presence of the insider holdings conditional on the corporation's competitive and governance environment.

Furthermore, the uniqueness of my data set represents my third contribution. My database of shareholder proposals covers the period of 1997-2006. This database is distinctive because it also includes information about withdrawn and omitted proposals. Withdrawn proposals are subject to private negotiations between corporate managers and proposal sponsors prior to the AGM. Eventually, they are withdrawn from the voting process. Omitted proposals, on the other hand, are removed from the voting agenda because they violate the SEC's regulations. In other words, these proposals are not put to a vote but they still occur. The studies on shareholder proposals (e.g., Gordon and Pound, 1993; Gillan and Starks, 2000) suffer from a selection bias in the sense that they focus only on proposals that the management admits to the voting process. These proposals have a low ex ante probability of receiving a majority. Restricting the analysis to these instances neglects the bulk of the corporations where no such proposal is filed by the investor base. More importantly, the restriction neglects the corporations in which the proposals are withdrawn because of private negotiations. Hence, I investigate all of the companies in the COMPUSTAT universe that have complete financial and ownership information available, irrespective of whether they were targeted or not, to circumvent this selection bias. The results of my chapter cast doubt on the prior studies' conclusions of ineffective shareholder voting. The shareholder proposals do not have to be 
voted on successfully to be effective. In my setup, the mere filing of the proposals is sufficient in preventing managerial entrenchment. According to my data, shareholder engagement is effective.

The remainder of this chapter is organized as follows. In the next section, I present my economic model and hypotheses. Section 2.3 presents the data and the data sources. In Section 2.4, I present the statistics on the shareholder proposals and my sample corporations. In Section 2.5, I perform the empirical analyses and present the results. Section 2.6 concludes.

\subsection{Economic framework and testable hypotheses}

I conjecture that two important governance mechanisms influence the occurrence of shareholder proposals and the associated voting outcomes. The first channel is exogenous in nature and cannot be changed by shareholders, namely the competitive environment a corporation is acting in. As a proxy for the competitiveness of the industry, I use the industry concentration level as measured by the HHI based on the 3-digit SIC code. As a second channel, I argue that the corporation's governance quality determines its vulnerability to shareholder proposals. I use the corporation's exposure to the takeover market as a proxy for the governance quality (i.e., the Governance Index as constructed by Gompers, Ishii, and Metrick, 2003; henceforth the G-index). A higher exposure to the takeover market lowers managerial entrenchment and increases the level of shareholder rights.

I develop an economic framework to derive my testable hypotheses. This twodimensional theoretical model illustrates how industry competition and the level of managerial entrenchment jointly influence the probability of being targeted by shareholder proposals. Figure 1 displays the structure. 


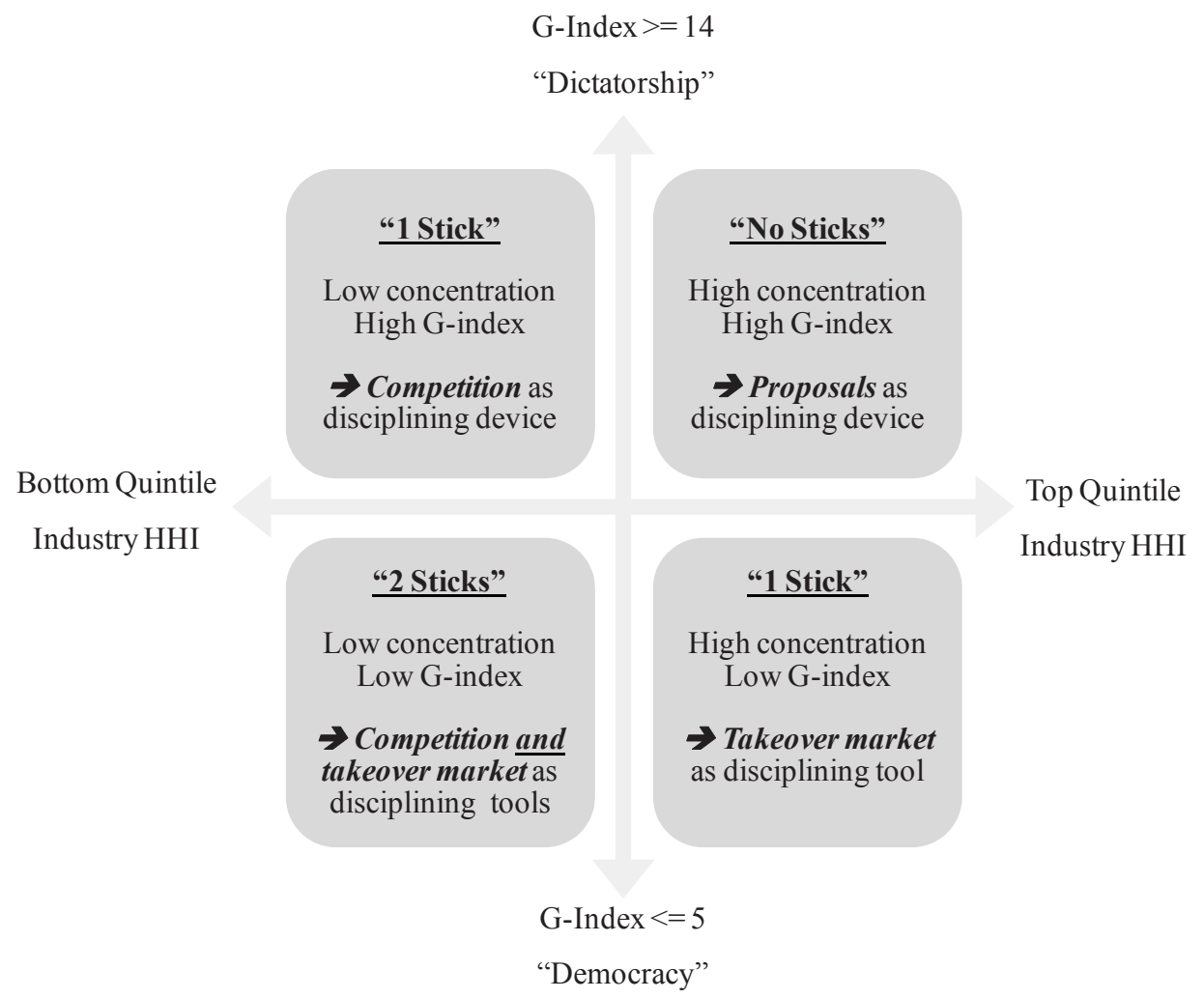

Figure 2.1: Economic Framework

This figure shows the economic framework that provides the theoretical foundation for this chapter. I distinguish corporations along two dimensions: shareholder rights and the degree of the industry competition. In particular, I investigate dictatorship corporations (in the spirit of Gompers, Ishii, and Metrick, 2003) (G-index $\geq 14$ ) and democracy corporations (G-index $\leq 5)$ operating in highly concentrated (top quintile of the industry Herfindahl-Hirschman Index (HHI)) or highly competitive industries (bottom quintile of the industry $\mathrm{HHI}$ ). Depending on the number of punishing devices the corporations have in place (sticks) the likelihood of being targeted by shareholder proposals varies. Most importantly, the upper right quadrant displays the highest likelihood of being targeted when other disciplining tools are absent.

Throughout the analysis I assume that the G-index reasonably measures the shareholder rights and hence the managerial entrenchment or takeover protection. I follow Gompers, Ishii, and Metrick (2003) and Giroud and Mueller (2010, 2011) to classify corporations as either democratic or dictator that are exposed to either a highly competitive or a concentrated industry. Based on Gompers, Ishii, and Metrick (2003) I classify corporations with a G-index smaller or equal to 5 as democracy corporations and corporations with a G-index equal to or larger than 14 as dictatorship corporations. Concerning my industry concentration measure, I adopt the same measure as Giroud and Mueller (2010). Accordingly, the industries in the top quintile with respect to the HHI of the respective 3-digit SIC code are considered to be highly concentrated. Correspondingly, industries in the lowest quintile of the HHI are considered as highly competitive industries. Consequent- 
ly, I differentiate between four different types of corporations: dictatorship/concentrated industry (Q1: Poorly governed corporations), democracy/concentrated industry (Q2), democracy/competitive industry (Q3: Well-governed corporations), and dictatorship/competitive industry $(Q 4)$.

Based on my setup, I hypothesize the following: First, I conjecture that corporations in $Q 1$ are highly prone to receiving shareholder proposals because these corporations lack the disciplining forces from both the takeover market and competition. The shareholders realize that the managerial discretion is the highest in these corporations and decide to file proposals that call for a change in the governance structures or the incentive policies. In contrast, the corporations that belong to the $Q 2$ or the $Q 4$ exhibit comparatively lower vulnerability towards shareholder proposals because in either case at least one governance mechanism is effectively present. The corporations in the $Q 3$ are least likely to be targeted by their shareholders. The reason for this claim is that the industry competition in this quadrant is high and these corporations also exhibit more shareholder rights that implies that both of the monitoring mechanisms are working properly, making it unnecessary for the shareholders to file proposals. Hence, I hypothesize:

H2.1: The corporations with low shareholder rights and weak industry competition (Q1) are more likely to receive shareholder proposals.

Second, the corporations located in the upper right quadrant should also exhibit steeper incentives in the form of option packages. This is because of the absence of punishing or disciplining devices from the takeover market and the industry. Therefore, the managers need to be given pecuniary incentives in the form of options in order to exert effort:

H2.1a: The corporations that face little industry competition and have low shareholder rights also have steeper incentives in the form of options than their well-governed counterparts. As a response, the shareholders file proposals on internal governance and compensation.

Third, I posit that the outside shareholder base is an important determinant of the occurrence and frequency of shareholder proposals. The economic rationale is the following. A larger shareholder base- both in terms of the actual number of common shareholders as well as the density and structure of the institutional shareholdings - increases the probability of one shareholder actually becoming active and filing a proposal. Furthermore, if the ownership concentration among the institutional shareholders is high as well, then the collusion between these shareholders occurs more easily. Correspondingly, I claim that the probability of being targeted with shareholder proposals increases with a concentrated institutional ownership and a larger shareholder base:

H2.1b: A higher institutional ownership concentration and a large shareholder base positively relate to the magnitude of filed shareholder proposals.

Lastly, concerning the voting outcomes of the admitted shareholder proposals, I argue that the internal shareholder base is a key determinant. The implicit collusion of the 
insiders is simple because they share common interests, objectives, and incentives. I hypothesize that the insiders are reluctant to accept intervention into the corporate strategy or the governance structure and indicate a preference to entrench. Hence, I argue that the insiders of the corporations in concentrated industries with strong takeover protection will exploit their holdings of voting rights in order to actively vote against the shareholder proposals. The management's alternative to blocking the shareholder proposals is to propose the compensation structures themselves via management proposals. In unreported tests on the managerial-sponsored compensation proposals, I find that these proposals have an unconditional acceptance rate of more than $95 \%$. Based on my framework I conjecture that:

H2.2: The voting outcomes of the admitted shareholder proposals have a negative relation to the insiders' equity holdings.

\subsection{Data}

\subsubsection{Shareholder proposals}

I use a unique data set that provides information on all of the shareholder proposals brought forward to S\&P1500 corporations between 1997 and 2006. The data is from RiskMetrics and consist of annual meeting dates, information about the proposal's content, filers, status, and the corresponding voting results. In total, my data set includes 9,082 shareholder proposals addressing corporate governance and corporate social responsibility issues. These proposals were either put to a vote, withdrawn prior to the annual meeting because of private negotiations, or were omitted from the proxy statement because they violated the SEC's proxy rules. I argue that previous studies suffer from a selection bias in that they neglect the withdrawn and omitted shareholder proposals. I circumvent this bias because I include them in my empirical analysis to study the actual probability of being targeted by shareholders.

I manually classify both the proposal's topics and sponsors into different groups. The coarse classification has four main categories: corporate governance (CG), corporate social responsibility (CSR), mixed issues, and other proposals. In the following empirical analysis I focus on the former two categories only. Following Karpoff, Malatesta, and Walkling (1996), Gillan and Starks (2000), Gompers, Ishii, and Metrick (2003), and Becht, Bolton, and Röell (2003), I break down the CG proposals into finer subclasses. The CG proposals consist of external corporate control proposals, internal governance proposals, and takeover proposals. The external governance proposals mostly consist of the proposals related to antitakeover devices and the market for corporate control in general. Most of the internal proposals deal with the board of directors, voting issues, and the executive compensation. Furthermore, I split up the CSR proposals into social and environmental proposals, which deal with the current buzzwords like human rights, health, diversity, and climate change. 
Furthermore, I distinguish between four different proposal sponsor groups: individual investors (e.g., Evelyn Davis, the Rossi family, etc.), institutional investors (e.g., asset managers, investment companies, pension funds, etc.), coordinated activists (religious and other interest groups), and unions (e.g., AFL-CIO, Teamsters, United Brotherhood of Carpenters, etc.). Appendix 2.A displays examples of each proposal topic and sponsor category.

\subsubsection{Insider ownership data}

A cornerstone of my chapter concerns the ownership structure of my sample corporations. I am interested in the fraction of voting rights owned by corporate insiders (i.e., the board) and whether these voting rights are used to block shareholder proposals at the annual general meetings (AGM). Pieces of the insider ownership information come from RiskMetrics that include detailed director information and the amounts of voting rights owned by each individual director. However, when two or more directors have voting power over a set of stock owned by a trust, a foundation, or another corporation, RiskMetrics assigns the corresponding voting rights to each director sitting on the board. This assignment means that the insider stock ownership sometimes exceeds $100 \%$ because of the multiple assignments of the stakes. Hence, I recalculate the ownership data if the holdings exceed a prespecified threshold of $80 \%$ by using proxy statements of the relevant corporations to get a more accurate measure of the director holdings. I use the following three-step method to recalculate the insider stock ownership that is based on Hermalin and Weisbach (1991) and DeAngelo and DeAngelo (1985): (1) Shareholdings owned by a trust, foundation, or another corporation are considered to be managerial holdings if the directors and/or the officers of the holding corporation are also sitting on the board of this particular corporation in which their corporation owns a stake. (2) To avoid double counting, I assign the ownership owned by a trust, foundation, or another corporation to only the director with the highest hierarchical position in the sample corporation. (3) In cases where the positions of the directors are unidentifiable, I attribute the stock ownership to only one director.

I then merge the RiskMetrics data with the COMPUSTAT Execucomp database to identify the incumbent CEO of the relevant companies. Following those steps I am able to calculate my proxies for the insider holdings: overall board ownership, the CEO holdings, and the HHI of the board's holdings of the voting rights as a concentration measure of the insider holdings.

\subsubsection{Institutional ownership data}

Next to the insider holdings of voting rights, I am also interested in the effects of the outside ownership structure on both the occurrence of the shareholder proposals and the outcomes of the proposals that are put to a vote. I use Thomson Reuters' 13(f) filings to retrieve the data on the holdings of the institutional investors and construct the following 
variables. I count the number of institutional $5 \%$ holders as well as the concentration of the institutional ownership with the following measure:

$$
H H I_{j t}=\sum_{i=1}^{N_{j}} s_{i j t}^{2}
$$

where $H H I$ is the Herfindahl-Hirschman Index of percentages held by institutional investors (as designated by the Thomson Reuters' institutional holdings $13 \mathrm{f}$ database) of firm $j$ in year $t$. I sum the squared percentages of each institutional investor $i$ at time $t$ across $N$ investors in firm $j$. I use the average of four quarterly filings per corporation and investor. Naturally, the index is bounded between zero and one. I further have a ratio of the total institutional share ownership. The economic logic behind counting the number of institutional blockholders is that more large shareholders are either more likely to disagree or to collude over shareholder proposals depending on the proposal content and sponsor identity.

In addition, I break down the institutional ownership structure further. Bushee (1998) classifies the Thomson Reuters database into eight distinct investor subgroups ${ }^{3}$ : (1) bank investors, (2) insurance companies, (3) independent investment advisors, (4) investment companies, (5) corporate pension plans, (6) public pension plans, (7) university funds and endowments, and (8) miscellaneous. Because of the potential ambiguities I summarize groups (3) and (4). I also compute the dollar values of the holdings in order to account for the differences in the market valuations and firm sizes. The economic reasoning behind the disaggregation of the institutional investor holdings is as follows: There are certain investor groups that are more likely to suffer from conflicts of interest and are subject to higher disagreement. Other investor groups, for example corporate pension funds and insurance companies, tend to outsource their proxy voting and are likely to vote with the management's recommendation possibly because of existing business ties with the target corporations (e.g., Cornett, Marcus, Saunders, and Tehranian, 2007; Chen, Harford, and Li, 2007).

\subsubsection{Firm, industry, and governance data}

I obtain the relevant firm-level data from COMPUSTAT. The data include information about the corporation's cash position, size, market-to-book ratio, dividend yield, past performance, and leverage. I approximate the corporation's age with the first listing date on CRSP. RiskMetrics is the source of the G-index, my measure for the governance quality, and the dual class status of my sample corporations. In my analyses I also control for managerial incentives. To do so, I use the scaled wealth-performance sensitivity developed by Edmans, Gabaix, and Landier (2009). This variable takes into account that managerial effort is multiplicative with respect to firm size. To obtain a measure for the

\footnotetext{
3 The classification of institutional shareholders is publicly available at Prof. Bushee's website: http://acct3.wharton.upenn.edu/faculty/bushee/IIclass.html
} 
industry concentration level, I calculate the HHI for every 3-digit SIC industry based on all of the COMPUSTAT firms. I calculate the industry HHI by summing all of the squared market shares (based on total sales) for all of the corporations in the respective 3-digit SIC industry.

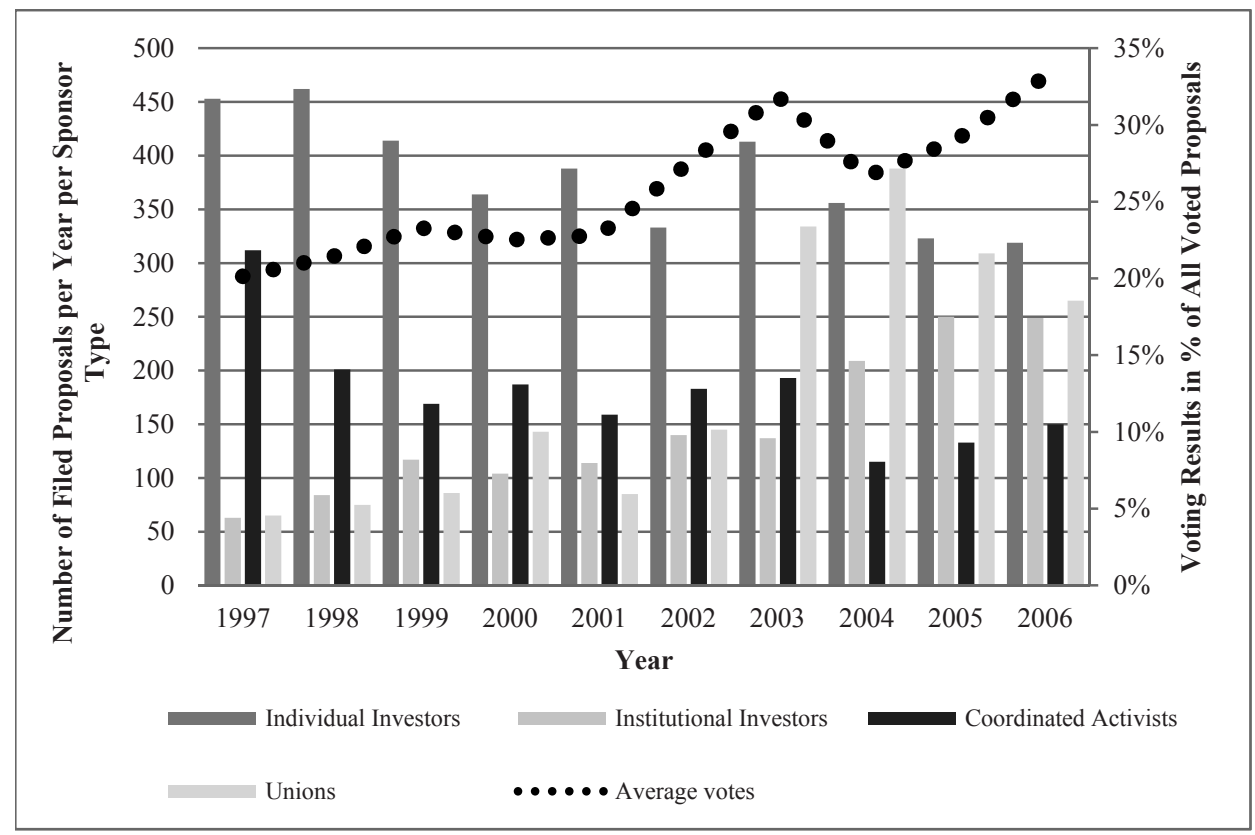

Figure 2.2: Number of filed proposals and average voting results over time

The graph below plots the number of filed proposals per year (broken down by sponsor identity) between 1997 and 2006 (left axis). The average voting result (in percent) of all of the voted shareholder proposals in a given year is shown by the dotted line (right axis).

\subsection{A closer look at shareholder proposals}

\subsubsection{Shareholder proposals and voting results}

As my data set covers the time period between 1997 and 2006, I can investigate the evolution of shareholder engagement over time. Figure 2.2 shows the number of proposals per year and per sponsor group over time. It also shows the average voting results in a given year. Several observations emerge from the evolution of the proposals. Initially, individual investors file by far the highest fraction of proposals, which gradually declines until 2006. Contemporaneously, the engagement by institutional investors has almost monotonically increased from 1997 to 2006. This result can be explained by a general increase in the institutional ownership in the US stock markets from 50 to over 70\% during my sample period (e.g., Gillan and Starks, 2007). Further, some striking 
findings are the sharp increase in the filed proposals by union funds after the passage of the Sarbanes-Oxley Act in 2002 and the seemingly reduced importance of coordinated activist groups over time. Concerning the success of the proposals, I recognize a steady increase in the average voting results that indicates that shareholder engagement through proxy proposals becomes more successful.

Investigating the voting results and the success rates of the different subsets of the shareholder proposals sheds further light on both the efficiency and the effectiveness of shareholder engagement (see Table 2.1).

I observe the largest number of voted proposals from the area of internal governance. However, the proposals with the highest voting outcome and acceptance rate are those on external governance. This rate might be because of the fact that takeover defenses are more pervasive and, as such, easier to vote on since there is less disagreement between the shareholders.

Even though the average voting result of compensation-related proposals has significantly increased over time, only a tiny fraction of the compensation proposals eventually gets accepted every year (varying between 0 and $5.88 \%$ of all voted compensation proposals). The lower part of Table 2.1 shows that the occurrence of CSR proposals displays a significantly increasing time trend. However, their successfulness remains very low, which might be attributed to larger disagreement among shareholder groups concerning CSR issues. 


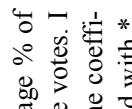

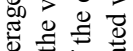

टे

:

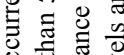

ठ류

要

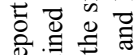

颉的

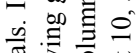

死

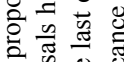

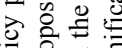

명.

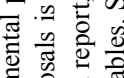

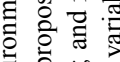

过总至

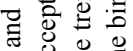

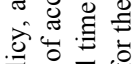

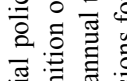

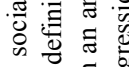

ชी ฮี

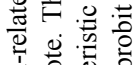

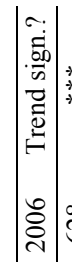

*

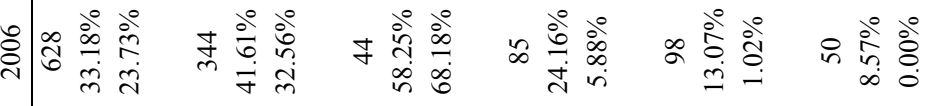

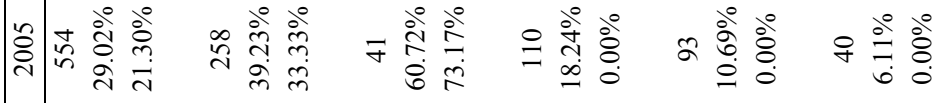

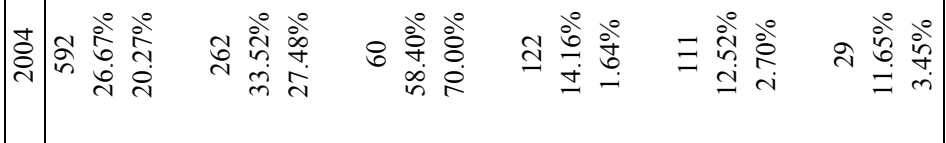

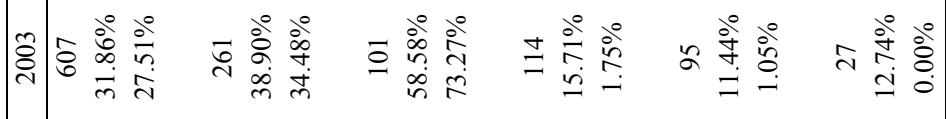

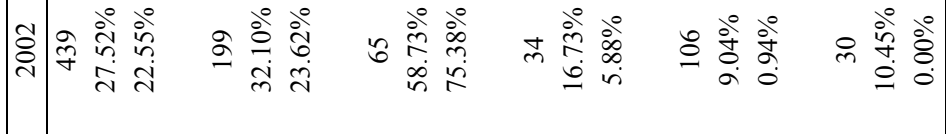

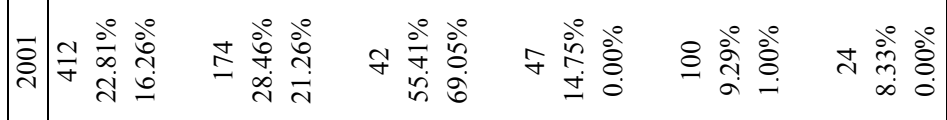

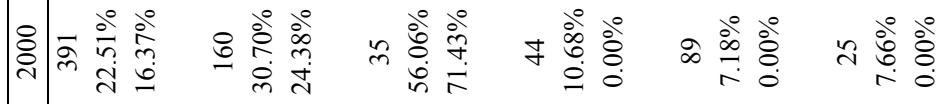

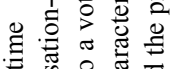

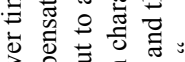

ठे 气े

论

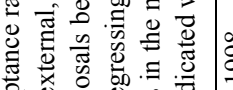

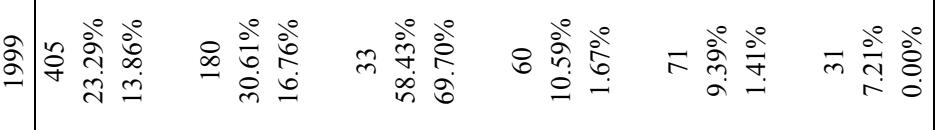

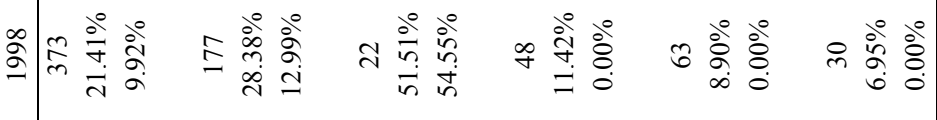

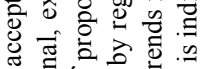

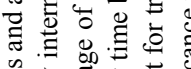

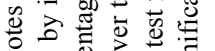

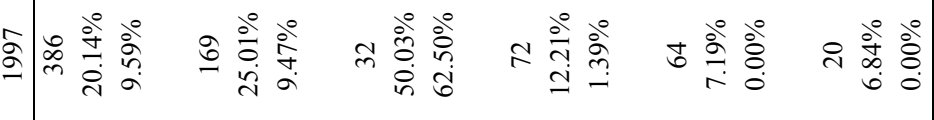
品

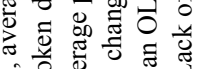
कि

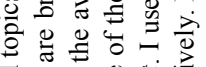
可 记

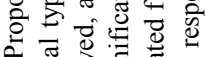

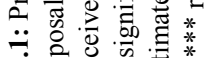
i

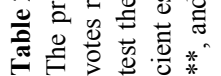

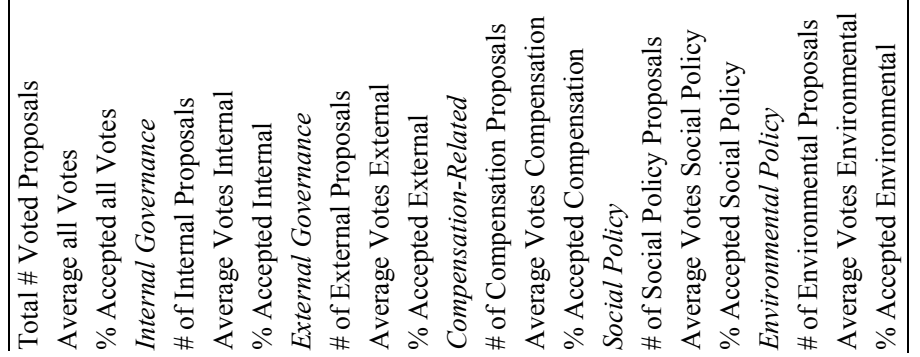




\subsubsection{Firm characteristics and proposals per governance quadrant}

I research four extreme samples of firms based on their prevalent level of shareholder rights and industry competition. I provide preliminary evidence for my hypotheses, based on Figure 2.1, and take a closer look at the proposal and the corporate characteristics per quadrant to check for patterns.

I note in Table 2.2 that $Q 2$ displays the highest frequency of shareholder proposals (132 filed, and 77 voted proposals). The $Q 1$ corporations receive only 80 proposals of which 45 are put to a vote. This finding gives a first indication on whether shareholders experience engagement via vote as a disciplining device or not. If they do, I expect to observe that the majority of the shareholder proposals occur in the upper right quadrant of my economic framework. Notably, in $Q 1$, a significant portion of the compensation proposals (43\%) are eventually withdrawn from the proxy forms. Further, I find that this quadrant displays the highest unconditional voting outcomes for the CG proposals $(47 \%$ on average). Well-governed corporations (Q3), on the other hand, display much lower unconditional voting results $(26 \%)$ for the $C G$ proposals. This result could indicate that shareholders view the proxy proposal process as irrelevant for well-governed firms, which is also supported by the fact that the number of filed proposals is also much lower than for the poorly governed corporations (44 vs. 80 ). 
Table 2.2: Proposals per governance-competition-quadrant

In this table, there are characterizations of each of the four quadrants from Figure 1 by the occurrence of shareholder proposals. "High G" is defined as a corporation from the dictatorship portfolio with a G-score greater than or equal to 14. "High HHI" has an industry concentration index in the top quartile of the distribution. Panel A distinguishes quadrant 1 from quadrant 4, and Panel B contrasts quadrant 2 and 3.

\begin{tabular}{|c|c|c|c|c|c|c|c|c|c|c|}
\hline \multirow[b]{2}{*}{ Panel A } & \multicolumn{5}{|c|}{ Dictatorship and Low Competition (Q1) } & \multicolumn{5}{|c|}{ Dictatorship and High Competition (Q4) } \\
\hline & $\begin{array}{l}\text { Number of } \\
\text { Proposals }\end{array}$ & $\begin{array}{c}\text { Number of } \\
\text { Voted } \\
\text { Proposals }\end{array}$ & $\begin{array}{c}\text { Average } \\
\% \\
\text { Votes }\end{array}$ & $\begin{array}{c}\text { e Number of } \\
\text { Withdrawn } \\
\text { Proposals }\end{array}$ & $\begin{array}{l}f \quad \% \text { of } \\
\text { n Withdrawn } \\
\text { S Proposals }\end{array}$ & $\begin{array}{l}\text { Number of } \\
\text { n Proposals }\end{array}$ & $\begin{array}{l}\text { Number } \\
\text { of Voted } \\
\text { Proposals }\end{array}$ & $\begin{array}{c}\text { Average } \\
\% \\
\text { Sotes }\end{array}$ & $\begin{array}{l}\text { Number of } \\
\text { Withdrawn } \\
\text { Proposals }\end{array}$ & $\begin{array}{l}f \quad \% \text { of } \\
\text { n Withdrawn } \\
\text { s Proposals }\end{array}$ \\
\hline $\begin{array}{l}\text { (1) Corporate } \\
\text { Governance }\end{array}$ & 61 & 34 & $47 \%$ & 11 & $18 \%$ & 55 & 19 & $41 \%$ & 15 & $27 \%$ \\
\hline External & 17 & 12 & $61 \%$ & 1 & $6 \%$ & 9 & 7 & $66 \%$ & 2 & $22 \%$ \\
\hline Internal & 33 & 17 & $44 \%$ & 6 & $18 \%$ & 32 & 8 & $27 \%$ & 11 & $34 \%$ \\
\hline Takeover & 4 & 2 & $34 \%$ & 1 & $25 \%$ & 5 & 1 & $16 \%$ & 0 & $0 \%$ \\
\hline Compensation & 7 & 3 & $12 \%$ & 3 & $43 \%$ & 9 & 3 & $28 \%$ & 2 & $22 \%$ \\
\hline $\begin{array}{l}\text { (2) Corporate Social } \\
\text { Responsibility }\end{array}$ & 16 & 9 & $6 \%$ & 3 & $19 \%$ & 12 & 3 & $6 \%$ & 4 & $33 \%$ \\
\hline Social & 12 & 9 & $6 \%$ & 2 & $17 \%$ & 5 & 0 & - & 2 & $40 \%$ \\
\hline Environmental & 4 & 0 & - & 1 & $25 \%$ & 7 & 3 & $6 \%$ & 2 & $29 \%$ \\
\hline (3) Other & 3 & 2 & $5 \%$ & 0 & $0 \%$ & 3 & 0 & - & 0 & $0 \%$ \\
\hline (4) Mixed & 0 & 0 & - & 0 & - & 0 & 0 & - & 0 & - \\
\hline \multirow[t]{2}{*}{ Total (1) - (4) } & 80 & 45 & & 14 & & 70 & 22 & & 19 & \\
\hline & \multicolumn{5}{|c|}{ Democracy and High Competition (Q3) } & \multicolumn{5}{|c|}{ Democracy and Low Competition (Q2) } \\
\hline Panel B & $\begin{array}{c}\text { Number } \\
\text { of } \\
\text { Proposals }\end{array}$ & $\begin{array}{c}\text { Number } \\
\text { of Voted } \\
\text { Proposals }\end{array}$ & $\begin{array}{c}\text { Average } \\
\% \\
\text { Votes } \\
\end{array}$ & $\begin{array}{l}\text { Number of } \\
\text { Withdrawn } \\
\text { Proposals }\end{array}$ & $\begin{array}{c}\text { \% of With- } \\
\text { drawn } \\
\text { Proposals }\end{array}$ & $\begin{array}{c}\text { Number } \\
\text { of } \\
\text { Proposals }\end{array}$ & $\begin{array}{c}\text { Number } \\
\text { of Voted } \\
\text { Proposals }\end{array}$ & $\begin{array}{c}\text { Average } \\
\% \\
\text { Votes }\end{array}$ & $\begin{array}{c}\text { e Number of } \\
\text { Withdrawn } \\
\text { Proposals }\end{array}$ & $\begin{array}{c}\% \text { of } \\
\text { Withdrawn } \\
\text { Proposals }\end{array}$ \\
\hline $\begin{array}{l}\text { (1) Corporate } \\
\text { Governance }\end{array}$ & 30 & 14 & $26 \%$ & 9 & $30 \%$ & 73 & 45 & $20 \%$ & 11 & $15 \%$ \\
\hline External & 0 & 0 & - & 0 & $0 \%$ & 3 & 3 & $38 \%$ & 0 & $0 \%$ \\
\hline Internal & 19 & 7 & $41 \%$ & 7 & $37 \%$ & 46 & 31 & $22 \%$ & 6 & $13 \%$ \\
\hline Takeover & 1 & 0 & - & 0 & $0 \%$ & 3 & 3 & $6 \%$ & 0 & $0 \%$ \\
\hline Compensation & 10 & 7 & $11 \%$ & 2 & $20 \%$ & 21 & 8 & $10 \%$ & 5 & $24 \%$ \\
\hline $\begin{array}{l}\text { (2) Corporate Social } \\
\text { Responsibility }\end{array}$ & 14 & 4 & $23 \%$ & 5 & $36 \%$ & 57 & 32 & $10 \%$ & 11 & $19 \%$ \\
\hline Social & 8 & 4 & $23 \%$ & 1 & $13 \%$ & 48 & 30 & $10 \%$ & 7 & $15 \%$ \\
\hline Environmental & 6 & 0 & - & 4 & $67 \%$ & 9 & 2 & $3 \%$ & 4 & $44 \%$ \\
\hline (3) Other & 0 & 0 & - & 0 & $0 \%$ & 2 & 0 & - & 0 & $0 \%$ \\
\hline (4) Mixed & 0 & 0 & - & 0 & $0 \%$ & 0 & 0 & - & 0 & $0 \%$ \\
\hline Total (1) - (4) & 44 & 18 & & 14 & & 132 & 77 & & 22 & \\
\hline
\end{tabular}




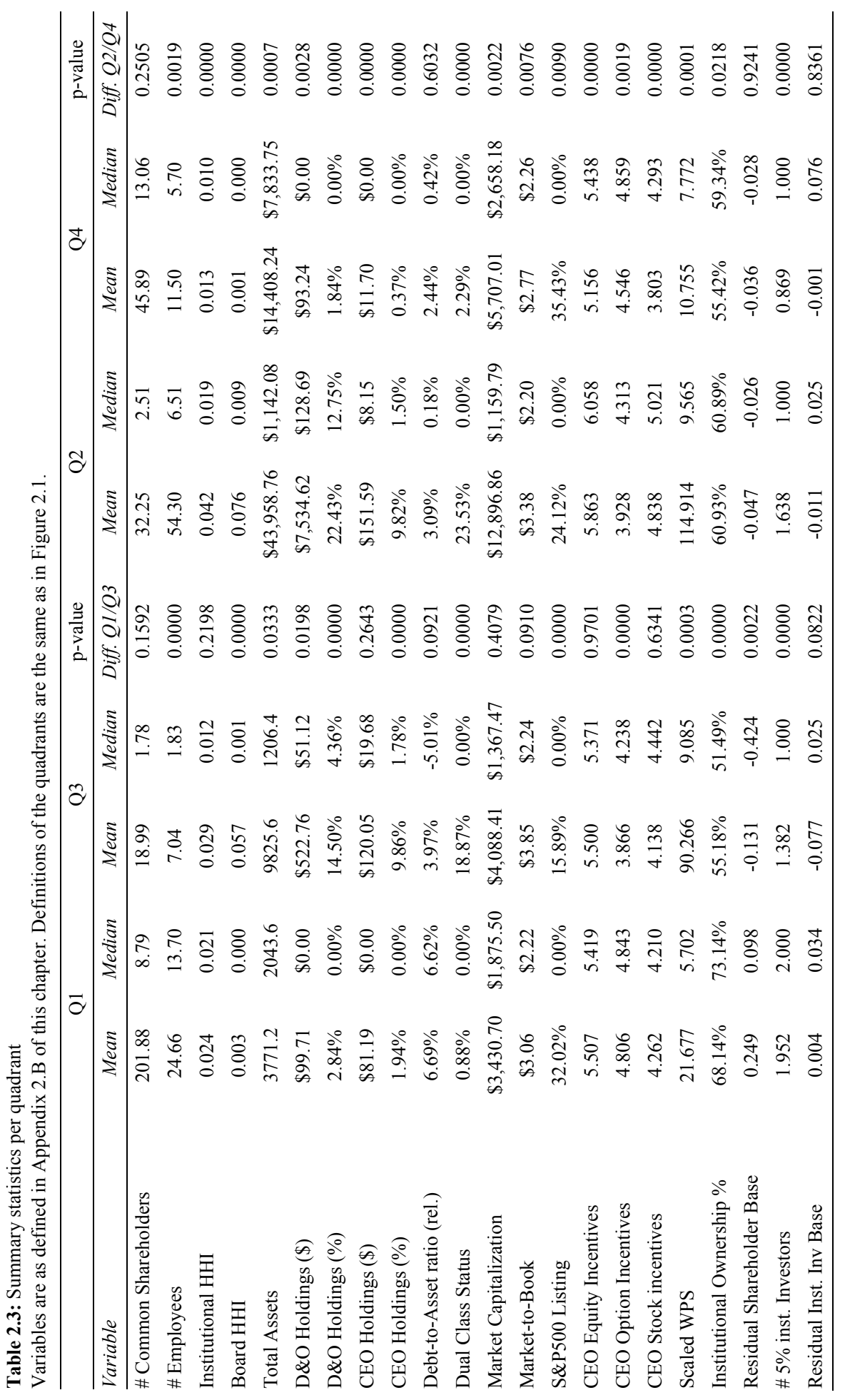


Turning to the firm, stock, and ownership characteristics of these quadrants, Table 2.3 provides evidence of the economic conditions for shareholder proposals to be successful. In Panel A of Table 2.3, I compare the extreme groups of the corporations: poorly and well-governed corporations ( $Q 1$ vs. $Q 3$ corporations). The most striking differences between these two groups lie in the level of stock option incentives. The managers of the poorly governed corporations have significantly more option incentives than the managers of the well-governed corporations. This is in line with the hypothesis of my economic framework. According to Hall and Liebman (1998), remuneration in the form of stock options has become the dominant form of explicit incentives for CEOs. I also find that relative to their well-governed counterparts, the poorly governed corporations have more employees, are smaller in terms of total assets, less frequently have dual classes of common stock, are more often members of the S\&P500, and have more institutional and blockholder ownership. Moreover, the boards of the well-governed corporations generally have a smaller stake in their corporation, both in terms of the dollar value as well as the fractional ownership.

\subsection{Method and empirical results}

\subsubsection{Endogeneity of the shareholder base and structure}

I investigate the effect of the ownership structure on the occurrence and the frequency of shareholder engagement as well as the corresponding voting outcomes of the proposals. For that purpose, I need to find suitable measures of (1) the ownership stakes held by the corporate insiders, (2) the number of institutional investors that hold stock in the corporation, and (3) the number of common shareholders in total. The problem with these variables is that they are strongly endogenous to firm and stock characteristics. For the last two variables, I therefore follow the method of Grullon, Kanatas, and Weston (2004) and Bodnaruk and Östberg (2013) and extract the residuals from the following regression to correct for the endogeneity before continuing with the empirical analyses.

I regress the skewness-adjusted number of the common shareholders (COMPUSTAT item \#100, measured in millions) on firm age, market capitalization, return on assets, market-to-book ratio, the inverse of share price, the stock's liquidity (monthly average trading volume), past year return, and past year volatility. These variables are chosen because the corporate and the stock characteristics attract different groups of investor clienteles and therefore cause different degrees of ownership concentration. As an example, an established NYSE blue-chip corporation with low volatility attracts more (institutional) investors than a young and risky corporation with little record of profitability. I control for the exchange listing and the industry grouping according to the Fama-French 12-industry classification. The same regression is run for the number of institutional investors that uses the same control variables. The results of the regression are in Table 2.4. 
Table 2.4: Determinants of shareholder base

In this table, there is a regression of (1) the logarithm of the number of common shareholders (in millions) and (2) the logarithm of the number of institutional investors on the following variables: the logarithm of the market capitalization (number of shares outstanding times share price), the logarithm of the firm age, the return on assets (operating income before depreciation divided by total assets), the logarithm of the market-to-book ratio, the inverse of the share price, the firm's liquidity of the stock (monthly trading volume), its past year return, and the volatility (standard deviation of monthly returns). I control for the exchange trading status and have NYSE as the base variable. I incorporate industry dummies according to the Fama-French 12-industry classification. My estimation technique is an OLS, and I adjust the standard errors for heteroskedasticity. Significance at 10,5 , and $1 \%$ level are denoted by $*, * *$, and $* * *$ respectively.

\begin{tabular}{|c|c|c|c|c|}
\hline \multirow[t]{2}{*}{ Variables } & \multicolumn{2}{|c|}{$\begin{array}{c}\log (1+\text { Number of Common } \\
\text { Shareholders })\end{array}$} & \multicolumn{2}{|c|}{$\begin{array}{c}\log (1+\text { Number of Institutional } \\
\text { Investors })\end{array}$} \\
\hline & Coefficient & t-stat & Coefficient & $t$-stat \\
\hline Intercept & $-2.603 * * *$ & -20.584 & $0.550 * * *$ & 11.574 \\
\hline \multicolumn{5}{|l|}{ Firm Variables } \\
\hline Firm Age & $0.148 * * *$ & 10.047 & $0.137 * * *$ & 27.415 \\
\hline Market Capitalization & $0.314 * * *$ & 21.740 & $0.336 * * *$ & 64.715 \\
\hline ROA & 0.004 & 0.492 & 0.002 & 1.529 \\
\hline Market-to-Book & $0.194 * * *$ & 13.154 & $0.054 * * *$ & 10.364 \\
\hline 1/Price & $0.061 * *$ & 2.113 & -0.002 & -0.283 \\
\hline Liquidity & $0.164 *$ & 1.850 & $0.215 * * *$ & 5.140 \\
\hline Past Year Return & 0.000 & 0.184 & $0.000 * * *$ & 6.107 \\
\hline Volatility & $-0.942 * * *$ & -8.197 & $-0.471 * * *$ & -10.625 \\
\hline \multicolumn{5}{|l|}{ Exchange Controls } \\
\hline AMEX traded & -0.061 & -0.965 & $0.071 * *$ & 2.423 \\
\hline NASDAQ traded & $1.568 * * *$ & 4.471 & $-0.749 * * *$ & -2.835 \\
\hline Industry FF12 controlled & \multicolumn{2}{|c|}{ yes } & \multicolumn{2}{|c|}{ yes } \\
\hline Adjusted $\mathrm{R}^{2}$ & \multicolumn{2}{|c|}{0.420} & \multicolumn{2}{|c|}{0.758} \\
\hline Number of Observations & \multicolumn{2}{|c|}{14,537} & \multicolumn{2}{|c|}{15,195} \\
\hline
\end{tabular}

Consistent with the literature on ownership structure, I note that larger and more liquid corporations are more likely to have a broader base of common shareholders. Surprisingly, I find that price matters to the common shareholder base but turns out to be nonsignificant for the institutional shareholder base. The transaction costs seem to matter more to the common shareholder base than to the institutional investors, which is in line with the economic reasoning. I find that glamor stocks are more likely to have a large investor base and have more institutional investors. Being very liquid in terms of trading volume plays a significant role both for the common as well as for the institutional shareholder base. From this regression, I extract the residual values and use them for the ongoing analysis in the later stage regressions of the shareholder proposal occurrence, frequency, and outcome.

As a third group of potential holders of voting rights, I turn to the role of corporate insiders. In order to correct for biases in firm sizes, I multiply each director's share of 
ownership with the year-end stock price in order to arrive at the share ownership corrected for dollar values. By construction, accumulating significant holdings at high share prices is more difficult for CEOs of large blue-chip stocks, which is why I account for the market cap. There is a rich body of literature pointing towards the endogeneity of insider holdings and executive compensation (see, e.g., Demsetz and Lehn, 1985; Demsetz and Villalonga, 2001). For that reason I decide to run the same regression as before for the share holdings of (1) the CEO of the corporations and (2) the holdings of all directors and officers in the corporation. I complement the set of stock and firm characteristics with a list of governance variables that show the explanatory power of the insider holdings (Core, Holthausen, and Larcker, 1999).

I find that for insider holdings, many of the previously observed coefficients of the shareholding structure are different. The insiders are more likely to hold larger fractions in value stocks and hold a larger fraction if the stock trades at low levels. The insiders also hold volatile stocks that performed well over the past year. With respect to the governance variables, I observe that the separation of the CEO and the chairman of the board results in less ownership and thus the CEO controls less votes. A very strong variable is whether the corporation has dual class status; in this case, both the CEO and the directors and officers hold a significantly larger fraction of the voting rights. The managers in the corporations with weak shareholder rights hold fewer shares. This is not necessarily in contrast to my empirical predictions where I expected poorly governed corporations to have steeper incentives because other corporate governance mechanisms are absent. My analysis is concerned with the degree to which managers use the voting rights they are bestowed with, not the absolute value of their holdings. Moreover, I find that the more independent directors on the board result in a lower degree of equity participation. This finding is indicative of the claim that independent directors are more likely to act in the interest of the corporate shareholders and thus restrict the use of excessive equity incentive practices. As before, I use the residual values of my regression in Table 2.5 in my later stage empirical analyses.

From this section, I conclude that there are significant stock and corporate characteristics that affect the internal and the external shareholder bases of the corporation. Next I evaluate the effects of this shareholder base on the occurrence, frequency, and the outcomes of shareholder engagement in the form of proxy voting. 
Table 2.5: CEO, director, and officer holdings

I regress the dollar value of CEO and director and officer holdings on a number of firm, governance, and ownership variables. All of the variables are as defined previously. Separate chair equals one if the functions of the CEO and the chairman of the board are separated. Board size and percentage of independent directors is obtained from the RiskMetrics "board and directors" tape. My estimation technique is an OLS, and I adjust the standard errors for heteroskedasticity. Significance at 10,5 , and $1 \%$ level are denoted by *,**, and *** respectively.

\begin{tabular}{|c|c|c|c|c|}
\hline & \multicolumn{2}{|c|}{$\begin{array}{l}\log (1+\mathrm{CEO} \text { dollar } \\
\text { Holdings })\end{array}$} & \multicolumn{2}{|c|}{$\begin{array}{c}\log (1+\text { Director and Officer } \\
\text { Dollar Holdings })\end{array}$} \\
\hline & Coefficient & t-stat & Coefficient & t-stat \\
\hline Intercept & $7.585 * * *$ & 22.415 & $9.736 * * *$ & 28.772 \\
\hline \multicolumn{5}{|l|}{ Firm Variables } \\
\hline Firm Age & $-0.148 * * *$ & -3.853 & $-0.262 * * *$ & -6.630 \\
\hline Market Capitalization & $0.204 * * *$ & 4.884 & $0.420 * * *$ & 9.220 \\
\hline $\mathrm{ROA}$ & $-0.018 * * *$ & -3.114 & $-0.010^{*}$ & -1.644 \\
\hline Market-to-Book & $-0.224 * * *$ & -6.426 & $-0.276^{* * *}$ & -7.288 \\
\hline 1/Price & $-0.854 * *$ & -2.356 & $-0.986^{* *}$ & -2.200 \\
\hline Liquidity & $-0.658 * * *$ & -8.118 & $-0.545^{* * *}$ & -6.774 \\
\hline Past Year Return & $0.002 * * *$ & 4.468 & $0.002 * * *$ & 3.823 \\
\hline Volatility & $0.318 * * *$ & 3.648 & $0.424 * * *$ & 4.578 \\
\hline Debt-Equity Ratio & 0.000 & 1.238 & 0.000 & -0.348 \\
\hline \multicolumn{5}{|l|}{ Governance Variables } \\
\hline Dual Class & $1.025^{* * *}$ & 10.600 & $1.270 * * *$ & 14.125 \\
\hline Separate Chair & $-1.055^{* * *}$ & -23.102 & $0.153^{* * *}$ & 3.050 \\
\hline G-Index & $-0.041 * * *$ & -4.556 & $-0.049 * * *$ & -4.965 \\
\hline Board Size & $-0.142 * * *$ & -12.880 & $-0.053 * * *$ & -4.569 \\
\hline$\%$ Independent Directors & $-0.021 * * *$ & -14.904 & $-0.037 * * *$ & -24.183 \\
\hline \multicolumn{5}{|l|}{ Ownership Variables } \\
\hline Institutional Ownership & $-0.556 * * *$ & -4.709 & $-1.592 * * *$ & -12.313 \\
\hline Shareholder Base & $-0.317 * * *$ & -13.548 & $-0.452 * * *$ & -18.346 \\
\hline \multicolumn{5}{|l|}{ Exchange control } \\
\hline NYSE dummy & 0.123 & 0.539 & $-0.338^{*}$ & -1.646 \\
\hline Industry FF12 controls & \multicolumn{2}{|c|}{ yes } & \multicolumn{2}{|c|}{ yes } \\
\hline Adjusted $\mathrm{R}^{2}$ & \multicolumn{2}{|c|}{0.251} & \multicolumn{2}{|c|}{0.284} \\
\hline Number of Observations & \multicolumn{2}{|c|}{9,052} & \multicolumn{2}{|c|}{9,690} \\
\hline
\end{tabular}

\subsubsection{Empirical results: Determinants of being targeted}

In the following, I investigate my first hypothesis that poorly governed corporations are more likely to be targeted by shareholder proposals. To shed light on this question, I adopt a pooled cross-sectional specification of the following kind: 
\# of proposals $s_{i, t}$

$=\alpha_{i}+\beta_{i}$ Corporation $_{i, t}+\gamma_{i}$ Owner $_{i, t}+\delta_{i}$ Governance $_{i, t}+$ Controls

In this specification, the dependent variable is the number of proposals a corporation $i$ receives in year $t$. It is important to recall that the number of proposals of corporation $i$ in year $t$ refers to the total number of proposals received by the corporation, including the withdrawn and omitted proposals. The Corporation represents a vector of several corporate characteristics. Specifically, I use the firm's cash position, age, total assets, marketto-book ratio, dividend yield, past performance, leverage, and the shareholder base. Owner represents a vector of ownership variables. Here, I control for the institutional shareholder base and the disaggregate holdings of certain types of institutional investors. Governance is a vector that comprises several different governance variables. This vector includes the variables of main interest: the governance index, managerial incentives, and the HHI based on the 3-digit SIC code for the industry concentration. Furthermore, I control for industry (Fama-French 12-industry classification), stock exchange, and year effects.

Table 2.6 presents the results of four different censored Tobit specifications. Model 1 uses all of the shareholder proposals in my sample (that is, the CG and CSR proposals), Model 2 includes the CG proposals only, while Models 3 and 4 use the external and the internal control proposals respectively. Recall, that I conjecture that the shareholder base and the governance quality are of particular importance for the filing decision of the proposals on any topic. Specifically, Residual Shareholder Base and HHI (institutional) represent my proxies for the size of the shareholder base and the level of concentration of the institutional holdings. The interaction term G-index*Industry HHI represents the most relevant variable concerning the governance quality of the corporations: A high G-index represents a low exposure to the takeover market, and a high $I n$ dustry HHI represents a low degree of competition. Hence, I expect to find a positive coefficient on this interaction term because this coefficient indicates that the degree of shareholder engagement is higher at corporations in which the pressures from the takeover market and the competition are absent.

The results in Table 2.6 support hypothesis $H 2.1$ : poorly governed corporations are more likely to receive a shareholder proposal. In all four models, the effect of the interaction term G-index*Industry HHI on the number of filed proposals is positive. This effect indicates that corporations that are not exposed to fierce competition and the takeover market are more likely to be targeted by shareholder proposals. The effect is significant in three out of four models: only for the external corporate control proposals is the effect nonsignificant. This absence of significance alludes to the fact that shareholders most likely recognize that the exposure to the takeover market cannot really be changed in poorly governed corporations, and thus the shareholders do not put forward proposals of this category.

Concerning the ownership structure of the corporations, I find a positive and highly significant coefficient on Residual Shareholder Base, which indicates that a larger shareholder base increases the probability of receiving a proposal. This result holds for 
all four models. Furthermore, I find that the concentration of the institutional shareholdings is always positively related to the number of shareholder proposals that a corporation receives in a particular year. Though the effect is nonsignificant in Models 1 and 4, this result is suggestive of the fact that a higher concentration of shareholdings among the institutions increases the likelihood that collusion on corporate issues might occur. This collusion, in turn, increases the probability that only one institution submits a proposal. Overall, these results support hypothesis $H 2.1 \mathrm{~b}$ that states that the structure of the shareholder base influences the occurrence of shareholder proposals.

The disaggregate institutional dollar holdings do not consistently influence the occurrence of shareholder proposals. Except for the holdings of insurance companies, all of the other coefficients are nonsignificant with mixed signs. This result does not necessarily imply that institutional shareholders do not engage in corporate monitoring, it only shows that institutional shareholders do not use shareholder proposals as a monitoring tool. My result points to the possibility that institutions - on an individual basis - are more likely to engage in corporate monitoring through other channels as discussed in later chapters of this dissertation. They might, for example, follow the Wall Street Walk (e.g., Edmans, 2009), simply threaten to exit (e.g., Edmans and Manso, 2011), or adopt private negotiations with the management (e.g., Carleton, Nelson, and Weisbach, 1998, and Chapter 4 of this dissertation).

The coefficients on the remaining control variables are generally consistent with the literature on shareholder engagement. I find that the likelihood of receiving shareholder proposals increases with poor past performance and corporate size. Moreover, my results indicate that mature corporations are more likely to be the targets of shareholder initiatives. The effects of my disaggregate dollar holdings of institutions remain inconclusive. Except for the negative effect of the shareholdings of insurance companies (significant in three models), no pattern in the disaggregate institutional holdings is observable. 


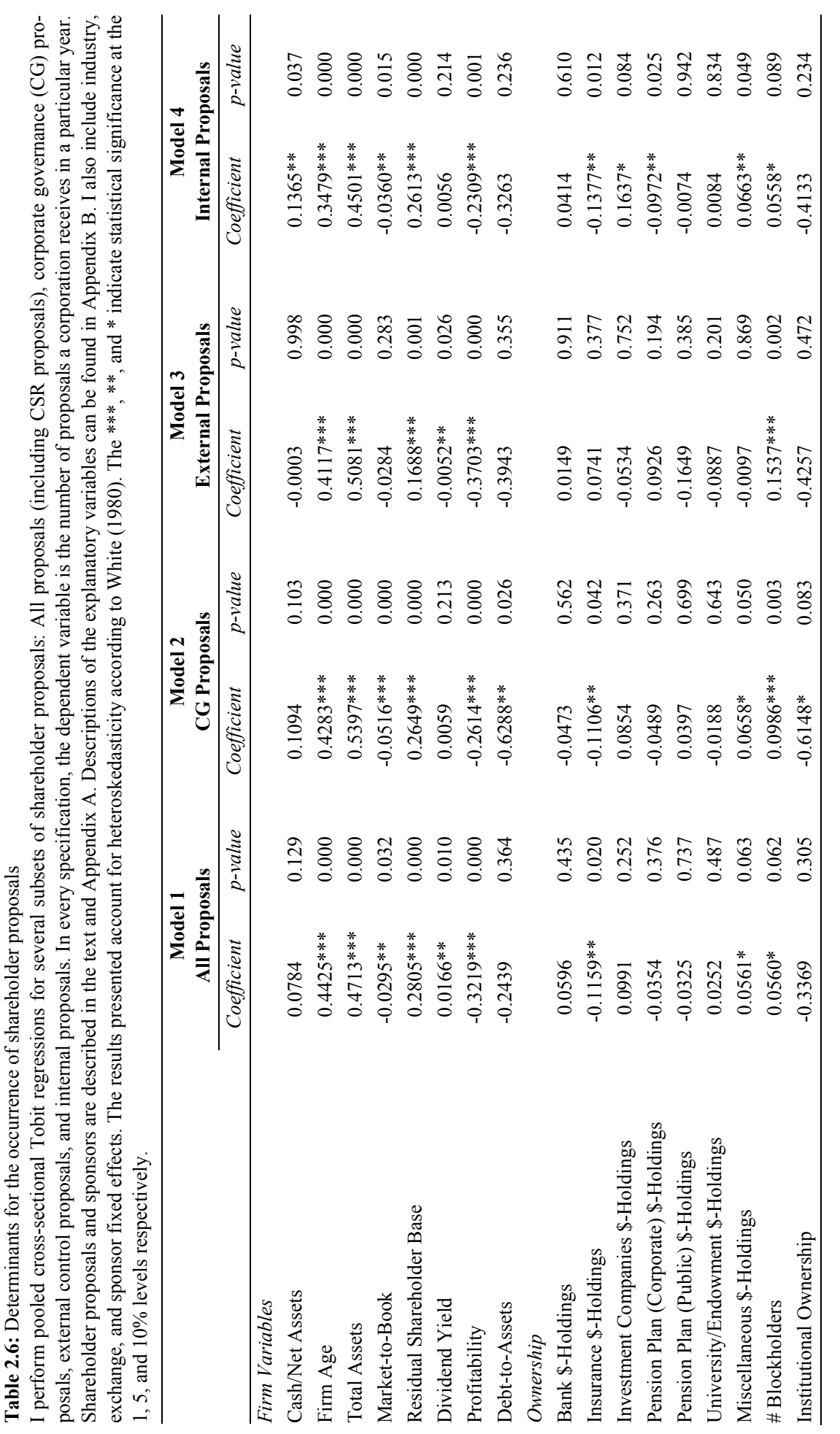




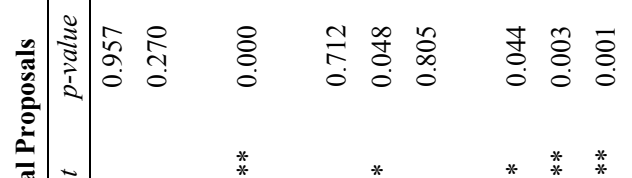

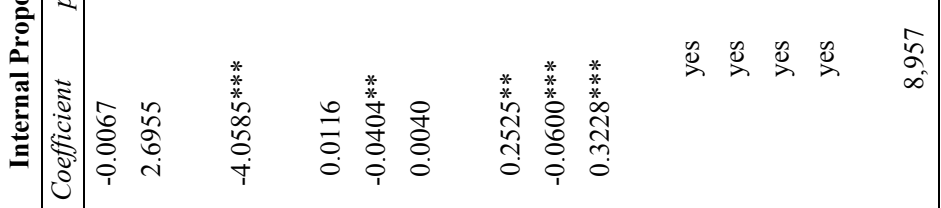

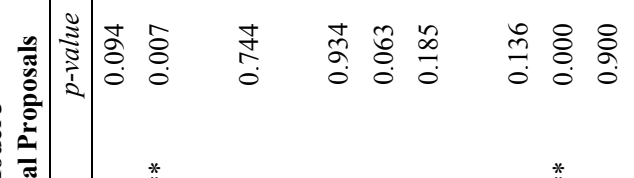

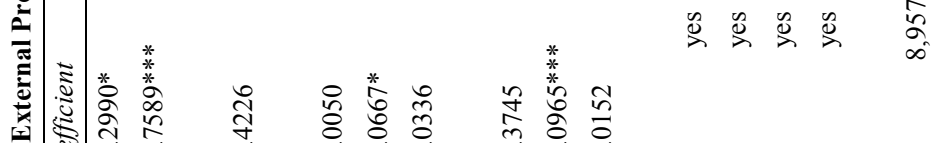

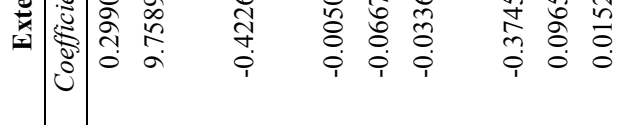

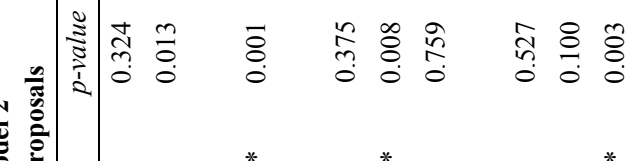

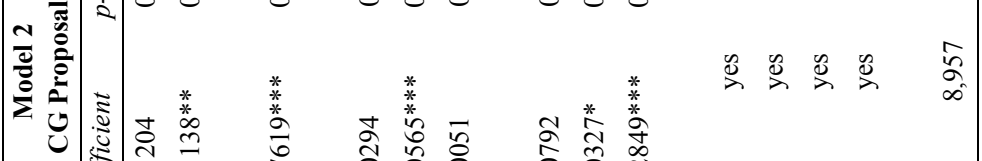

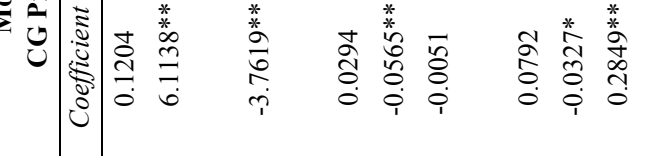

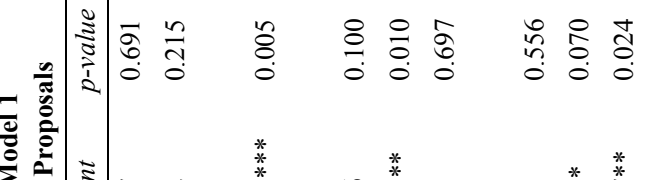

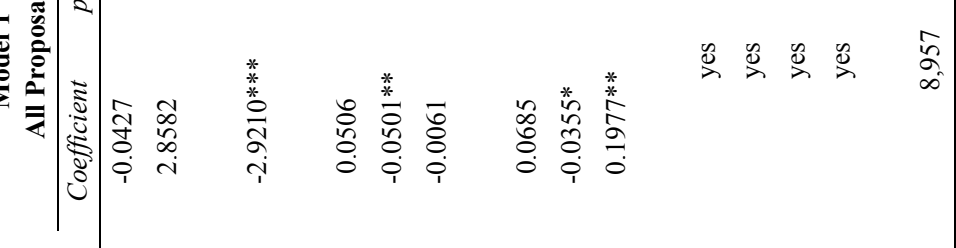

|| 
I conclude from this section that the presence of shareholder engagement depends crucially on the disciplining forces from the takeover market and the industry competition: If both are absent, the magnitude of shareholder engagement increases. ${ }^{4}$ That is, shareholder engagement is a substitute for other governance mechanisms that are entirely absent or have failed. However, the analyses so far only give an indication about the presence of shareholder engagement; that is, in how far shareholders become active at AGMs. The results do not show if other shareholders vote with the "activist" shareholders or not. In other words, the results do not show how successful and efficient shareholder engagement is or which factors influence the efficiency of the shareholder proposals. I investigate this issue in the following section.

\subsubsection{Voting outcomes of shareholder proposals}

Having identified the determinants of being targeted by shareholder proposals, I now turn to the examination on the voting outcomes of the proposals. The voting outcomes are of particular interest as they amplify the shareholders' ability to promote changes in the governance structures or the social policies of corporations. Knowing which factors lead to higher or lower voting results helps in shaping the voting recommendations of the proxy advisory firms and in guiding the shareholders as to where to bundle their efforts to file a proposal. Table 2.7 presents the results of my analysis of the voting outcomes. As before, I adopt a pooled cross-sectional approach. The four models are estimated using ordinary least squares with heteroskedasticity-consistent standard errors. I adopt the following specification:

$$
\% \text { votes }_{i t}=\alpha_{i}+\beta_{i} \text { Firm }_{i t}+\gamma_{i} \text { Owner }_{i t}+\delta_{i} \text { Governance }_{i t}+\text { Controls }
$$

where the dependent variable is the percentage of votes cast in favor of a particular shareholder proposal. The explanatory variables are defined as before. In this subsection, I am particularly interested in the effect of the insider holdings of voting rights on the voting outcomes of the shareholder sponsored proposals, especially when other corporate governance tools are absent. Hence, the variables of major interest are: Board HHI, which measures the concentration of holdings among board members; Q1 dummy, which equals unity if the corporation is part of the upper right quadrant in my economic model; and the interaction term Q1 dummy*Board HHI, which measures the joint effect of poor governance quality in combination with the equity holdings of board members.

Overall, the empirical results of Table 2.7 support hypothesis $H 2.2$ as the insiders' equity holdings are negatively related to the voting outcomes of the shareholder proposals: The coefficient on Board HHI is negative and significant in all four models. However, the economic magnitude is largest for the internal control proposals.

\footnotetext{
${ }^{4}$ My results also hold for alternative measures of managerial entrenchment, e.g., a classified board or the Entrenchment Index (E-index) developed by Bebchuk, Cohen and Ferrell (2009). The results do not materially differ from the ones reported here. The results are available on request.
} 


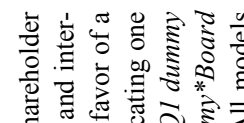

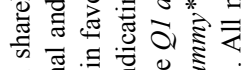

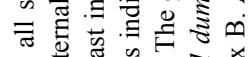

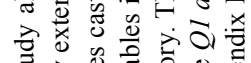

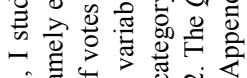

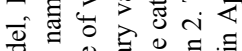

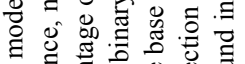
क 势 要哭吅

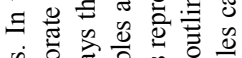

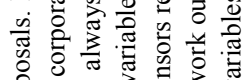

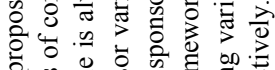

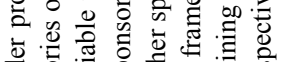

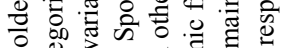

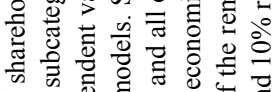

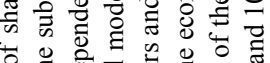

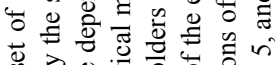
依

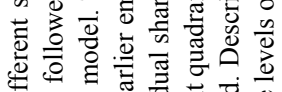
接 o

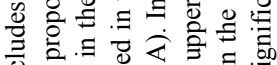

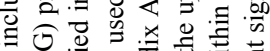
흐을

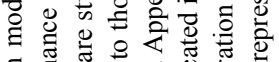
绕

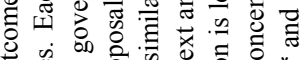
彭

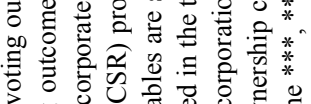

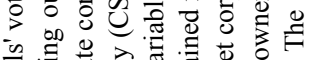

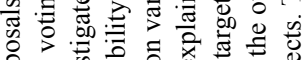

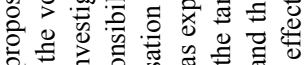

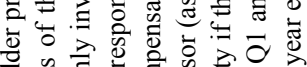

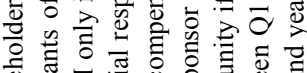

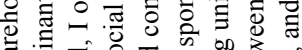

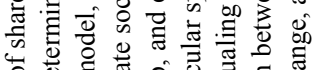

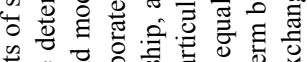

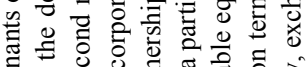
势

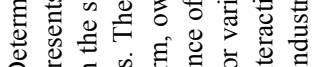

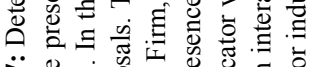

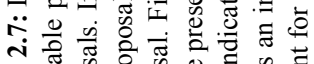

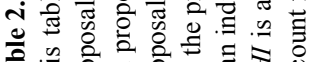

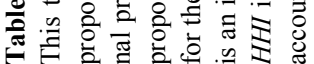

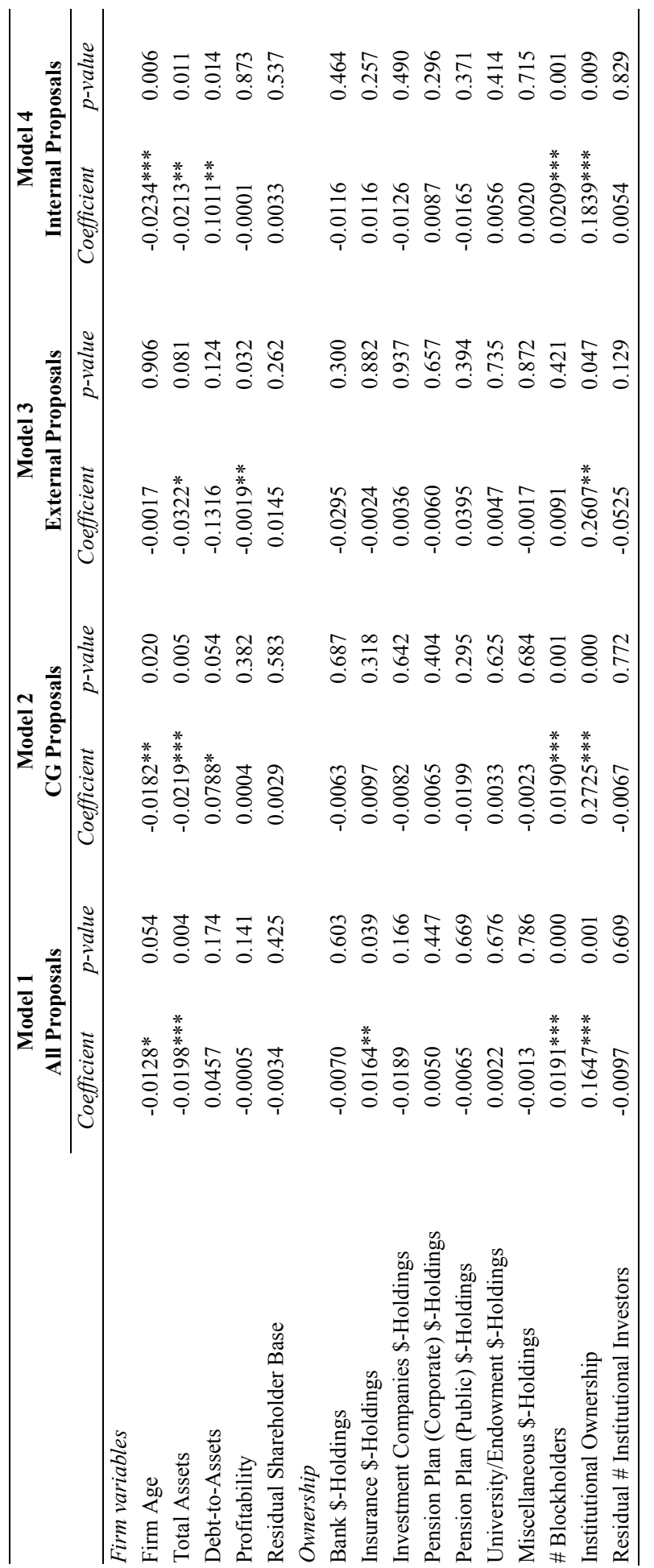




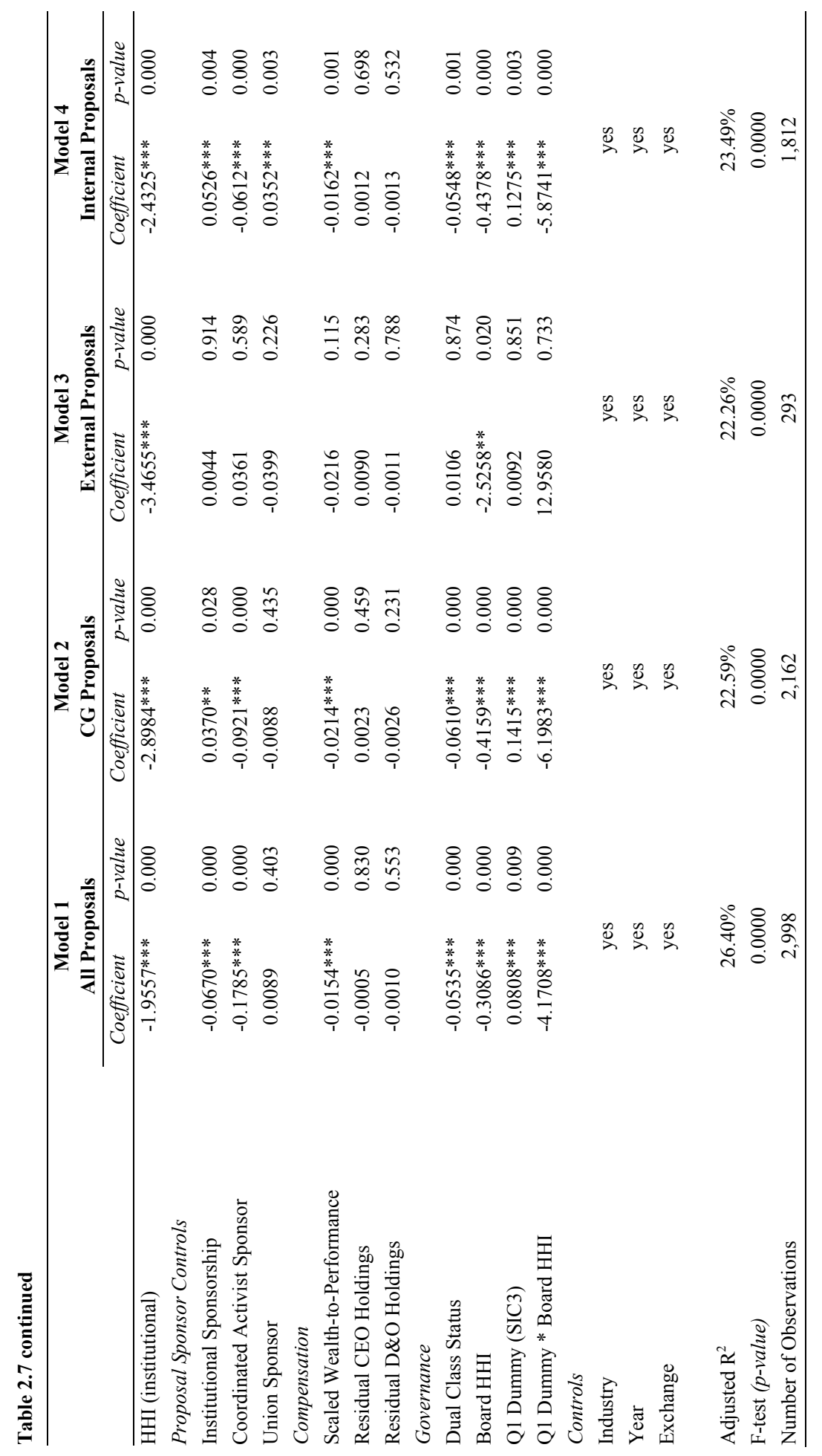


This result implies that as more voting rights are concentrated among the board members, the lower the voting outcomes get. In other words, the insider holdings of the voting rights are voted against the shareholder proposals of any kind; they significantly suppress the voting outcomes of the proposals. This effect becomes even stronger when taking the governance quality of the corporations into account. The proposals submitted to the corporations that are poorly governed in terms of their exposure towards the takeover market and the industry competition receive significantly less votes when the insider ownership concentration is high. However, the voting results of the external governance proposals are not negatively related to the interaction term Q1 dummy*Board HHI.

Several other variables influence the voting outcomes of the shareholder proposals. In particular, the number of blockholders (\# Blockholders), overall institutional holdings (Institutional ownership), and the ownership concentration among institutions [HHI (institutional)] significantly influence the voting outcomes of the proposals. These results stand in sharp contrast to Gordon and Pound (1993) who find that institutional shareholdings do not significantly affect the voting outcomes of shareholder proposals. I further find a negative relation between the scaled wealth-to-performance measure (as developed by Edmans, Gabaix, and Landier, 2009) and the voting outcomes in all four of the models. Because the scaled wealth-to-performance variable measures the incentives provided to managers irrespective of firm size, in my context it measures how managerial incentives affect the voting outcomes.

The results of this section show that the corporate insiders are consistently voting against the shareholder proposals, particularly in poorly governed corporations. ${ }^{5}$ The shareholders recognize that the managers are in a dominant position if their corporation is not exposed to fierce competition and the managerial labor market. Consequently, they become active in the form of proxy proposals. However, the success of these proposals is heavily suppressed by the insiders' voting rights.

\subsection{Concluding comments}

In this chapter, I shed light on the determinants of the occurrence and the successfulness of shareholder engagement via proxy proposals. I investigate whether the presence of disciplining forces from the takeover market and the industry are mitigating factors for the emergence of the shareholder engagement. Hence, I study whether shareholder engagement act as a substitute for the other governance mechanisms. The results indicate that the managers have steeper incentives in the form of options as soon as they are not exposed to external governance channels. I find that the likelihood of receiving a shareholder proposal significantly increases when the corporations are poorly governed: the corporations that are not exposed to takeover pressures and fierce competition in the industry are significantly more likely to be targeted by proposals.

\footnotetext{
${ }^{5}$ The results do not change if I use the total percentage of equities held by insiders or piecewise linear ownership variables instead of the HHI for insider holdings. The results are available on request.
} 
My results further indicate that the insider shareholder base is an important determinant of the voting outcomes of the proposals. I show that the voting results of the proposals are significantly suppressed by corporate insiders. This result is particularly pronounced for the proposals at poorly governed corporations. By using their own voting rights to vote against the shareholder proposals, the corporate managers are able to entrench themselves because they can attenuate the effectiveness of the proxy proposal process as a governance mechanism.

The results are important for several parties. First of all, the results show that shareholders should become active in poorly governed corporations. Even if shareholders ex ante know that the proposals are not binding and generally do not receive a majority vote, the mere filing of a proposal might induce managers to work harder. I believe that the filing of a proposal effectively signals to the market that the corporate managers are underperforming. Ultimately, this signal is incentive enough for the corporate managers to exert effort. Second, the results also have important implications for corporate managers. I claim that the sheer filing of a proposal is a nuisance to the managers because they are concerned about their reputation. Instead of exposing themselves to negative publicity during AGMs, the managers should invite the proposal sponsors into private negotiations to bargain a withdrawal.

These private negotiations offer in my opinion interesting research opportunities. There is almost no evidence on private negotiations induced by shareholder proposals. One possibility is to analyze the role of the withdrawn shareholder proposals and their effectiveness as a corporate governance mechanism. The results of such an analysis might show whether the shareholder engagement channel really can bring about changes in corporations. The following chapter of this dissertation contains such a deeper analysis of withdrawn proposals. There, I shed more light on withdrawn shareholder proposals and their potential to be effective corporate governance devices. 


\section{Appendix 2.A: Proposal topics and sponsor categories}

\begin{tabular}{ll}
\hline Proposal Topics (Content) & Topic Examples \\
\hline $\begin{array}{l}\text { Corporate Governance } \\
\text { Internal Governance Proposals }\end{array}$ & $\begin{array}{l}\text { Separate chairman/CEO introduce confidential voting, repeal } \\
\text { classified board, limit director tenure, introduce confidential } \\
\text { voting, award performance-based stock options, award golden } \\
\text { parachutes, link pay to performance, approve executive compen- } \\
\text { sation, restrict director compensation }\end{array}$ \\
& $\begin{array}{l}\text { Redeem or vote on poison pill, eliminate supermajority provision, } \\
\text { vote on takeover provisions, restore right to call a special meeting } \\
\text { External Governance Proposals }\end{array}$ \\
Sakeover & coll the company, reject merger, spin off division, spin off tobac-
\end{tabular}

Corporate Social Responsibility

Social Proposals

Label gene-engineered food, adopt sexual orientation anti-bias policy, implement ILO standards and third-party monitoring, issue sustainability report, adopt code of conduct for China operations

Environmental Proposals

Endorse Ceres principles, report on global climate change, report on supplier environmental standards, reduce radioactive emissions, develop renewable energy alternatives

\begin{tabular}{ll}
\hline Proposal Sponsors (Identities) & Sponsor Examples \\
\hline Institutional Investors & California Public Employees' Retirement System, New York City \\
& Pension Funds, Calvert Asset Management Co., Domini Social \\
& Investments, LongView Funds, Connecticut Retirement Plans \& \\
& Trust Funds, Northstar Asset, Trillium Asset Management \\
& Evelyn Davis, Davis family, Gilbert brothers, Rossi family, \\
& Lucian Bebchuk \\
Individual Investors & Interfaith Center on Corporate Responsibility, Medical Mission \\
& Sisters, Human Life International, Episcopal Church, Rainforest \\
& Action Network, People for the Ethical Treatment of Animals, \\
& Pro Vita Advisors \\
& United Brotherhood of Carpenters and Joiners of America, Ser- \\
& vice Employees International Union, Plumbers \& Pipefitters \\
& National Pension Fund, Utility Workers Union of America, AFL- \\
Unions & CIO, International Brotherhood of Electrical Workers, Interna- \\
& tional Brotherhood of Teamsters \\
\hline
\end{tabular}




\section{Appendix 2.B: Central Variables used in the analysis}

\begin{tabular}{|c|c|}
\hline Variable Name & Definition and Source \\
\hline \# Common Shareholders & $\begin{array}{l}\text { Common shareholder base: defined as the number of common shareholders } \\
\text { listed in COMPUSTAT in millions (item \# 100) }\end{array}$ \\
\hline \# Employees & Number of employees employed by the firm as listed on COMPUSTAT (\#29) \\
\hline Institutional HHI & $\begin{array}{l}\text { Institutional ownership concentration: sum of squared percentages held by } \\
\text { institutional investors (source: Thomson Reuters } 13 \mathrm{~F} \text { ) }\end{array}$ \\
\hline Board HHI & $\begin{array}{l}\text { Insider ownership concentration: sum of squared percentages of ownership of } \\
\text { corporate insiders (source: RiskMetrics and 10K filings on SEC Edgar) }\end{array}$ \\
\hline Total Assets & Balance sheet total assets from COMPUSTAT (item \# 6) \\
\hline D\&O Holdings ( $\$$ ) & $\begin{array}{l}\text { Dollar value of director and officer holdings at year-end (percentage holdings } \\
\text { times year-end stock price) }\end{array}$ \\
\hline D\&O Holdings (\%) & $\begin{array}{l}\% \text { of voting rights held by directors and officers (source: RiskMetrics and } \\
10 \mathrm{~K} \text { filings from SEC Edgar) }\end{array}$ \\
\hline CEO Holdings (\$) & $\begin{array}{l}\text { Dollar value of CEO holdings at year-end (percentage holdings times year- } \\
\text { end stock price) }\end{array}$ \\
\hline CEO Holdings (\%) & $\begin{array}{l}\% \text { of voting rights held by CEO (source: RiskMetrics and 10K filings from } \\
\text { SEC Edgar) }\end{array}$ \\
\hline Debt-to-Asset Ratio & $\begin{array}{l}\text { Long-term debt plus debt in current assets to total assets (COMPUSTAT item } \\
\text { \# } 9 \text { plus \# } 34 \text { over \# 6) }\end{array}$ \\
\hline Dual Class Status & $\begin{array}{l}\text { Equals unity if the firm has been incorporated with at least a dual class share } \\
\text { (source: RiskMetrics) }\end{array}$ \\
\hline Market Capitalization & $\begin{array}{l}\text { Year-end market capitalization: number of shares outstanding times stock } \\
\text { price (COMPUSTAT item \# } 25 \text { times \# 199) }\end{array}$ \\
\hline Market-to-Book & Market Capitalization over book value of equity (COMPUSTAT item \# 60) \\
\hline S\&P500 Listing & Equals unity if the firm belongs to the S\&P500 index \\
\hline CEO Equity Incentives & Resembles the logarithm of the dollar value that the CEO's wealth increases \\
\hline CEO Option Incentives & with a $1 \%$ change in stock price. Constructed for his or her entire equity \\
\hline CEO Stock incentives & $\begin{array}{l}\text { portfolio (“total”), "option" portfolio, and "stock" portfolio. Please refer to } \\
\text { Core and Guay }(1999,2002)\end{array}$ \\
\hline Scaled WPS & $\begin{array}{l}\text { Scaled wealth to performance measure from Edmans, Gabaix, and Landier } \\
\text { (2009) }\end{array}$ \\
\hline Institutional Ownership & $\begin{array}{l}\text { Percentage of outstanding common stock held by institutional investors. } \\
\text { (source: Thomson Reuters 13F) }\end{array}$ \\
\hline Res. Shareholder Base & $\begin{array}{l}\text { Residual of a regression of \# Common Shareholders on financial and firm } \\
\text { variables (see Table 2.4) }\end{array}$ \\
\hline \# 5\% Inst. Investors & $\begin{array}{l}\text { Number of institutional investors that hold at least } 5 \% \text { of outstanding com- } \\
\text { mon stock }\end{array}$ \\
\hline Residual \# Inst. Investors & $\begin{array}{l}\text { Residual of a regression of \# Institutional Shareholders on financial and firm } \\
\text { variables (see Table 2.4) }\end{array}$ \\
\hline
\end{tabular}





\section{CHAPTER 3 \\ The Determinants of Withdrawn Shareholder Proposals ${ }^{6}$}

In this chapter, I study more than 12,000 shareholder proposals filed with S\&P1500 companies from 1997-2009 and investigate the determinants of withdrawn shareholder proposals. I find that institutional ownership is positively related to the withdrawal's likelihood. In particular, the ownership of long-term, passively investing institutions and institutional sponsorship significantly increase the likelihood of withdrawal. My results also show a negative relation between the insider ownership and the withdrawal's likelihood. The effects of the ownership structure on the withdrawal's likelihood are less pronounced for corporate social responsibility proposals. Furthermore, proposals sponsored by institutions are also more likely to be withdrawn relative to proposals filed by private investors. My empirical evidence points to the importance of withdrawn shareholder proposals as a corporate governance mechanism. Managers try to protect their own power and reputation by preventing filed shareholder proposals from being put to a vote during the annual general meeting. They do so by entering into private negotiations with the sponsors of the proposals to accomplish a withdrawal.

\footnotetext{
${ }^{6}$ This chapter is based on Bauer, Moers, and Viehs (2013). I thank Jaap Bos, Jeroen Derwall, Stefanie Kleimeier, Nils Kok, Paulo Rodrigues, Roland Rott, David Yermack, my discussants Ioannis Ioannou and Raluca Roman, and the seminar participants at Maastricht University for helpful comments and suggestions.
} 
CHAPTER 3 


\subsection{Introduction}

Corporations in the United States are often faced with shareholder engagement that strives to change the corporate governance (CG) structures or the corporate behavior. One particular form of engagement is the voice engagement through shareholder proposals. The shareholders are allowed to submit proposals that are put to a vote during the annual general meeting (AGM). ${ }^{7}$ However, under special circumstances the submitting shareholder (i.e., the proposal sponsor) withdraws his or her proposal prior to the AGM. Usually, this withdrawal happens after negotiations between the management and the shareholder take place (Chidambaran and Woidtke, 1999). Corporations frequently invite activist shareholders to private negotiations following a shareholder-initiated proposal because managers do not want to put certain proposals to a vote during the AGM. The reason is that some proposals might adversely affect the managers' own interests or reputation. Also, the managers could evaluate the shareholder proposals as being not beneficial to the corporation and hence enter private negotiations for a proposal's withdrawal. As Chidambaran and Woidtke (1999) point out, the proposal sponsor voluntarily withdraws his or her proposal when the negotiations with the management turn out to be successful. However, if the shareholder decides not to withdraw the proposal, it will be put to a vote during the AGM eventually.

I define a successful negotiation as one in which both parties reach an amicable arrangement (settlement) that leads to a proposal's withdrawal by the proposal sponsor. Such a settlement can materialize in several different ways. The most obvious and logical way is that the management implements the proposal, either completely or partially, and thereby satisfies the proposal sponsor so that he or she withdraws the proposal. As Landier and Nair (2009) point out, a withdrawal of a shareholder proposal is an indication of the management's willingness to implement the requests made in the proposal. Another mode is that the management approaches the shareholder by offering symbolic changes in the corporation other than those requested in the original proposal. These symbolic changes, or "lip service" (Landier and Nair, 2009), are usually less uncomfortable for the managers but still satisfy the shareholders sufficiently enough to convince them about a proposal's withdrawal. A different, but more speculative, manner is that the corporation can reach a settlement with the shareholder by providing him or her with monetary incentives to withdraw the proposal without actually implementing the proposal at all.

In this chapter, I investigate the determinants of the likelihood of the proposal's withdrawal. My evidence suggests that approximately $20 \%$ of all filed shareholder proposals in the United States are withdrawn during the sample period of 1997-2009. My data shows that the proposals filed by institutional shareholders and unions display the highest withdrawal rates, whereas the proposals submitted by individual investors show

\footnotetext{
${ }^{7}$ According to Loss and Seligman (2004), shareholders are entitled to submit a shareholder proposal if they hold $1 \%$ or $\$ 2,000$ in market value of the outstanding voting stock for at least one year.
} 
the lowest withdrawal rates. Notably, the corporate social responsibility (CSR) proposals are withdrawn relatively more often than the CG proposals.

Generally, the results of my empirical analyses show that both institutional sponsorship and institutional ownership in the targeted corporations are positively correlated with the likelihood of the proposal's withdrawal. Especially the ownership stakes of long-term, passively investing institutions (quasi-indexers) are positively related to the likelihood of the proposal's withdrawal. My results indicate that the insider ownership significantly decreases the withdrawal's likelihood, which is consistent with my empirical predictions. This result is most pronounced for the CG proposals and is consistent with the evidence from Carleton, Nelson, and Weisbach (1998) and Chidambaran and Woidtke (1999). I do not find a significant relation between the insider ownership and the likelihood of the CSR proposals' withdrawal.

My findings allude to the fact that the withdrawal's likelihood is a function of the target corporation's ownership structure and the proposal's sponsor and content. Furthermore, I show that the proxy proposal process itself is an important corporate governance mechanism because I observe a high number of filed and withdrawn proposals over the entire sample period. Hence, I conclude that managers and shareholders give a lot of attention to this governance mechanism.

The importance of voice engagement through proxy proposals manifests itself in the fact that the shareholders have been filing proposals with US corporations since the mid$1990 \mathrm{~s}$ - even though the proposals are not binding on the management. This fact means that the shareholders expect to promote corporate changes through the proposals. Also, by means of the proposals, they expect to raise awareness among other shareholder groups that certain corporations are not managed in the most efficient way. Without these expectations, the shareholders would not have spent the time, money, and effort on filing the proposals.

The academic literature also shows a growing interest in shareholder engagement by means of the proposals. However, these studies miss the evidence on withdrawn proposals as a governance mechanism. The literature looks at the voting outcome as a measure for the success of the proposal (e.g., Gillan and Starks, 2000; Gordon and Pound, 1993), the role of the proposal as a substitute for other governance mechanisms (e.g., Chapter 2 of this dissertation), and the voting behavior of institutional shareholders (e.g., Ashraf, Jayaraman and Ryan Jr., 2009; Davis and Kim, 2007). Most of these studies conclude that the proxy proposal process itself is rather inefficient because the voting outcomes of shareholder proposals are on average less than 50\%. Even more important is the fact that the shareholder proposals are only advisory. The management can still refuse to adopt the recommendations put forward in the proposals, even if the voting outcome is higher than $50 \%$. Furthermore, several studies investigate the specific subsamples of voted shareholder proposals to draw conclusions about their ability to promote corporate changes (e.g., Buchanan, Netter, Poulsen, and Yang, 2012; Ertimur, Ferri, and Muslu, 2011). I add to this stream of literature by investigating the special class of the withdrawn proposals that has largely been neglected in these studies.

There are several reasons why withdrawn shareholder proposals are important to investigate. First and foremost, what becomes apparent from the aforementioned studies 
is the fact that the literature on shareholder proposals thus far largely neglects the presence of private negotiations. Therefore, I conclude that the studies that only take voted proposals into account yield biased results, because the important class of withdrawn proposals has been disregarded. To my knowledge, only two studies directly address the private negotiations and the proposal withdrawals. Carleton, Nelson, and Weisbach (1998) investigate the activist strategies of TIAA-CREF, the Teachers Insurance Annuity Association-College Retirement Equities Fund, a major institutional investor in the United States. They study the private correspondence between TIAA-CREF and the target corporations. Carleton, Nelson, and Weisbach (1998) find that TIAA-CREF successfully reached an agreement (i.e., a compromise) with the target companies in $71 \%$ of the cases - even before a proposal was voted on. In the remaining $29 \%$ of the private contacts, the target corporation and TIAA-CREF did not reach a compromise and consequently, TIAA-CREF's proposals went to a vote during the AGM. The achievement of an agreement between the shareholder and the target corporation is exactly the process that I am going to study in this chapter.

Next to Carleton, Nelson, and Weisbach (1998), there is only one other study that focuses explicitly on the withdrawn shareholder proposals, namely Chidambaran and Woidtke (1999). Their study is most closely related to mine. They examine the shareholder proposals and the determinants of their withdrawals in the context of the 1992 SEC proxy reforms. The authors find that withdrawal's likelihood decreases with the insider ownership. Chidambaran and Woidtke (1999) attribute this to the relative negotiation abilities of the sponsors and the managers. When the managers control a larger fraction of the corporation's voting rights, they can more easily resist the shareholder proposals and can let them go to a vote accordingly. In contrast to my results, they do not establish a significant relation between the withdrawal's likelihood and institutional ownership.

A second reason why withdrawn proposals are very important to investigate is that I observe that proposal sponsors continue to be frequently invited into private negotiations by the management team. This is reflected by the large number of withdrawn proposals between 1997 and 2009. Hence, there must be a reason why managers enter into the private negotiations with the shareholders rather than letting a proposal go to a vote during the AGM. I argue that the managers are more likely to settle with the shareholders when they want to avoid those proposals that might have adverse effects on the manager's reputation from being put to a public vote at the AGM. In fact, Landier and Nair (2009, p. 36) also describe the withdrawn proposals as being "equivalent to a majority vote" because a "withdrawal achieves the shareholders' purpose."

The implications of this chapter are the following. I shed light on the importance of the entire shareholder proposal process by taking into account voted, withdrawn, and omitted proposals. My evidence suggests that not only the voted proposals matter in this process but the entire engagement process. This process also includes the continuous dialogues between the shareholders and the corporations, and hence, also the withdrawn proposals that are the result of these private dialogues. Already the mere filing of a proposal provides management with a signal that the shareholders are willing to talk about certain concerns they have. Additionally, the managers, as initiators of the private nego- 
tiations, could use my results to determine the likelihood that a shareholder will withdraw his or her proposal. My results recommend that the managers incorporate the information on the corporation's ownership structure and the proposal's content and sponsor into the decision on entering into private negotiations. Similarly, my results are also of value for the filing shareholders. Given my results, shareholders could anticipate at which corporations the managers are more responsive to proposals. More specifically, shareholders are able to evaluate under which circumstances a satisfactory compromise can most likely be achieved.

Although my sample of withdrawn shareholder proposals is very rich, I cannot observe the entire negotiation process. That is, I only know whether a proposal has been withdrawn, omitted, or whether it has been put to a vote. I do not observe if a filed proposal was preceded by informal negotiations before its actual filing. Hence, I can only assume that a withdrawn proposal occurred after it was filed, regardless of whether private pre-negotiations took place before the actual filing or not.

The remainder of this chapter is organized as follows. Section 3.2 provides the theoretical foundation for my research and presents the testable hypotheses. In Section 3.3, I present the data and the methodology. In Section 3.4, I describe the evolution and nature of the withdrawn shareholder proposals from 1997-2009. Section 3.5 presents the results of my empirical analyses on the determinants of the proposal withdrawal. Section 3.6 concludes and discusses the implications of my third chapter.

\subsection{Theoretical background and hypotheses development}

\subsubsection{Background information on the shareholder proposal process}

The purpose of the following short synopsis on the proxy proposal process is to emphasize the importance of voice engagement through shareholder proposals in general, but also the importance of withdrawn shareholder proposals in particular. The entire proposal and withdrawal process is complex. For shareholders to be eligible to submit a proposal, they have to acquire a stake in the corporation, namely $1 \%$ or $\$ 2,000$ in market value of the voting stocks (Loss and Seligman, 2004). After having acquired this stake, a shareholder is entitled to submit one proposal to the corporation. However, the submission of a proposal does not necessarily mean that the proposal is also put to a vote during the AGM. Instead, three outcomes are possible. In the first outcome, the managers can let the proposals go directly to a vote during the AGM. That is, the shareholder proposal is included in the proxy statement and thus appears on the voting agenda of the AGM. Another outcome is that the management contacts the SEC in order to verify if all of the regulatory reasons for a proposal's omission are fulfilled. If the SEC agrees, the management is allowed to omit the proposal, and hence, it does not appear on the voting agenda. Thirdly, the managers can invite the sponsoring shareholder into negotiations on a proposal withdrawal. This latter outcome occurs when the management does not want to put the proposal to a vote. Hence, the managers want to reach a compromise that con- 
vinces the sponsoring shareholder to withdraw the proposal. If no consensus is reached, then the sponsor does not withdraw his or her proposal. Consequently, no withdrawal leads to an inclusion of the proposal in the proxy statement that results in a vote during the AGM.

From the aforementioned description of the shareholder proposal process, a degree of uncertainty is apparently involved as to what the outcome of a filed proposal will be. Despite this uncertainty, shareholders are still using voice engagement through their proposals to promote changes in corporations. What are the underlying motivations for (institutional) shareholders to adopt voice engagement through proxy proposals? This question is of crucial importance because shareholders have the opportunity to approach corporations informally and on a private basis before the actual filing of the proposal. The shareholders have several different motives to file a proposal.

Generally, I argue that (institutional) shareholders use the proxy proposal process to signal their willingness to talk to managers, irrespective of whether the filed proposal is eventually put to a vote or withdrawn. This public signal is very strong as it also raises the awareness of the other shareholders, making managers more likely to invite the sponsoring shareholders in for private talks.

Another motive for filing a proposal are failed private engagement activities. As stated before, most engagement - especially by institutional shareholders - takes place behind the scenes. As shown by McCahery, Sautner, and Starks (2013), many institutional investors undertake voice engagement with investee corporations to promote changes. Generally, I argue that institutional shareholders engage with investee corporations privately by continuously writing letters, emails, or making telephone calls to the management. This engagement is usually not observable and does not become public because the communication between institutional shareholders and corporations is considered confidential. However, if this private engagement fails, then the shareholders view the proposal mechanism as the only remaining means of putting pressure on the managers, because this mechanism is public and can be observed by other shareholders as well.

A related reason for shareholders to file a proposal is that management teams and the investor relations departments have time constraints. Consequently, the corporations cannot talk to every shareholder who contacts them privately. This time constraint argument is the reason why some shareholders file proposals right away.

Another reason for filing proposals is that the proxy proposal process is a continuous procedure with a lot of interaction and collaboration between the shareholders. The proposals that fail to get a majority vote in a given proxy season could be resubmitted in the next year. This is, of course, conditional on achieving at least the so-called resubmission thresholds specified by the SEC. But even if a proposal does not achieve at least those resubmission thresholds, another proponent can file the same or a similar proposal in the upcoming proxy season. Hence, shareholders also file proposals because of failed proposals in a previous proxy season. In doing so, shareholders want to increase the awareness of the other shareholders and the managers to signal that they are very concerned about particular issues. Thus, the shareholders have several motives for filing proposals. 
Elaborating on these motives is necessary, as the withdrawal of a proposal is entirely conditional on the filing of a proposal.

\subsubsection{The withdrawal process}

Figure 1 displays my theoretical framework that I use to describe the forces that lead to the withdrawal of a shareholder proposal.

An active but discontent, large shareholder who wants to improve corporate performance or change corporate behavior has two options for voice engagement as illustrated in Figure 3.1. When exiting (i.e., selling the stake) is not a feasible option to the shareholder, he or she can either approach the corporation publicly by immediately filing a proposal (upper part in Figure 3.1) or approach the corporation privately (lower part of Figure 3.1).

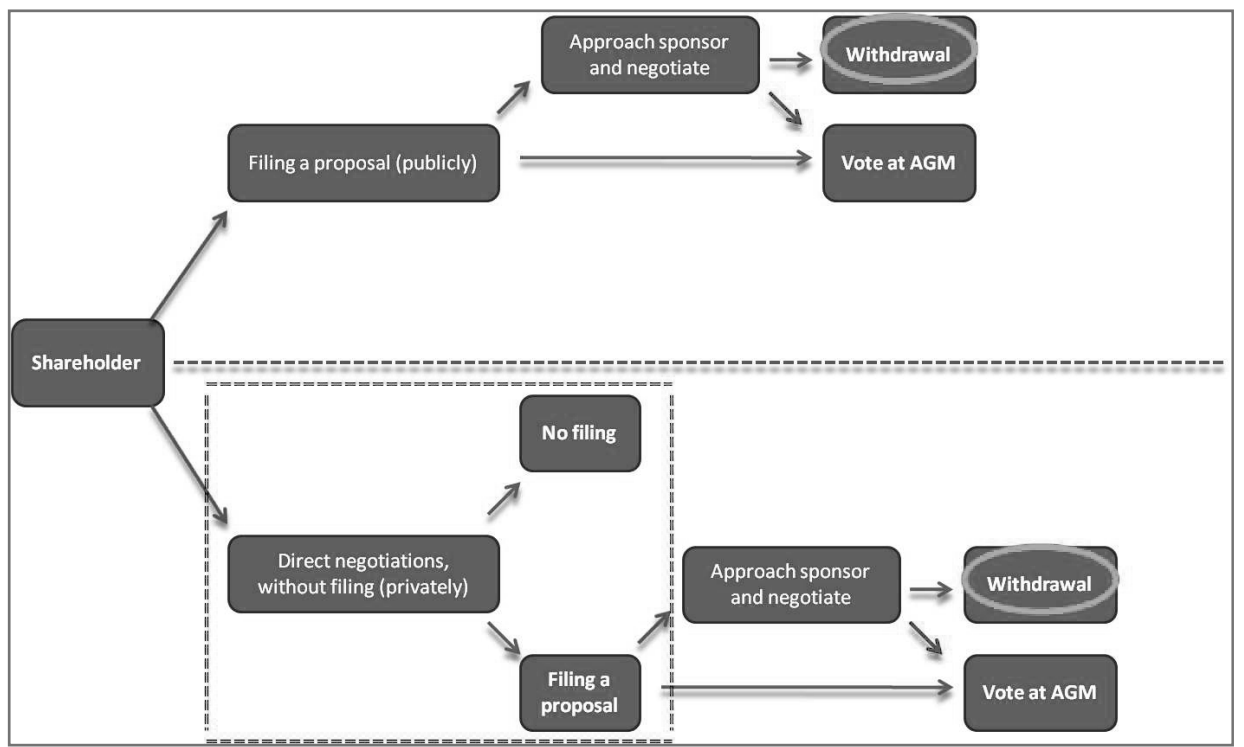

Figure 3.1: The withdrawal process

This figure presents the underlying theoretical framework I use to describe the withdrawal and engagement process. The dashed line in the middle of the graph separates the two different options a shareholder has when he or she wants to adopt voice engagement to promote changes in the corporations. The upper part of this figure represents the route when the shareholder immediately starts with the filing of a proposal. The lower part depicts the voice engagement route that starts with the private engagement activities. The dashed rectangle in the lower part represents the unobservable part of the engagement process: Private pre-negotiations before a filing of a proposal takes place. It is the part that I cannot observe from my data. A detailed explanation of this process is given in Subsection 3.2.2 of this chapter.

Conditional on the shareholder's decision to file a proposal, whether the managers enter into negotiations on a proposal withdrawal or let the proposal immediately go to a vote during the AGM is at their discretion. The upper part of Figure 3.1 shows that when the 
corporation decides to approach the filing shareholder and to enter into negotiations, the withdrawal of the proposal is not a certainty. If no satisfactory compromise for the filing shareholder is reached, then he or she most likely does not withdraw the proposal. In this case, the proposal is put to a vote during the AGM. Alternatively, if the negotiations are successful in the sense that the shareholder is satisfied with the concessions made to him or her, then the proposal is withdrawn. However, if the corporation decides not to enter into negotiations with the shareholder at all, then the proposal goes into the proxy statement, and a vote is held during the AGM accordingly.

The lower part of Figure 3.1 depicts the sequence of events when the shareholder follows the second option of voice engagement, namely private negotiations without any upfront public filing of a proposal. I conjecture that this voice engagement is likely not to be pursued by small, private investors because the continuous private engagement with corporations incurs a high degree of time and money. When a shareholder follows this engagement, the engagement establishes a private and continuous contact with the corporation. This contact can be done by management meetings, telephone calls, or emails to address issues that are of concern to the shareholder. In the event that the private negotiations "behind the scenes" provide a satisfactory outcome to the shareholder (i.e., the management surrenders), no further action is undertaken. Hence, no shareholder proposal is filed.

However, if the result of the negotiations behind the scenes is not satisfactory to the shareholder, he or she can view the filing of a proposal as the last remaining way of influencing managerial actions and simultaneously raising the public's and other shareholders' attention. The filing of such a shareholder proposal is perceived differently by management than a proposal that is immediately filed without any private contacts. The managers carefully evaluate whether a proposal, which is filed subsequent to failed private talks, should be put to a vote or whether they should instead re-enter into private negotiations to circumvent any negative publicity or reputational damages as a consequence of putting the proposal to a vote. Thus, the potential outcomes of such a proposal are the same as in the previous scenario: either management lets the proposal go to a vote immediately, or it invites the sponsoring shareholder into private negotiations to reach a settlement. In the case that no settlement is reached, the proposal is eventually put to a vote.

To sum up, withdrawn proposals can have two different causes. First, a filed proposal without any pre-negotiations behind the scenes can be withdrawn after negotiations between the sponsoring shareholder and the management of the target corporation (upper part of Figure 3.1). Second, a proposal can be withdrawn that has been filed after pre-negotiations behind the scenes have failed (lower part in Figure 3.1). From my data, these two types of withdrawn proposals are not distinguishable from each other. However, this finding does not change the nature of the withdrawn proposal itself and hence does not impair my general conclusions on the observed withdrawals or my contribution to the literature. 


\subsubsection{Testable hypotheses}

From the aforementioned description of the withdrawal process and the evidence on private negotiations provided by Carleton, Nelson, and Weisbach (1998) and Chidambaran and Woidtke (1999), I can derive my research hypotheses concerning the determinants of the withdrawal's likelihood.

To start with, I conjecture that institutional shareholders play an important role in the withdrawal process. The importance of this shareholder group as a governance mechanism has also been emphasized in other studies. For example, the literature on corporate governance shows that especially large shareholders or institutional investors play an important role when it comes to efficient managerial oversight because they have more incentives to oversee managerial actions and are able to solve the collective action problem (e.g., Burkart, Gromb, and Panunzi, 1997; or Shleifer and Vishny, 1986). Specifically, shareholder engagement as one particular governance mechanism is the most efficient if it is conducted by institutional investors such as hedge or pension funds (e.g., Wahal, 1996; Smith, 1996; Prevost and Rao, 2000; Brav, Jiang, Partnoy, and Thomas, 2008; Klein and Zur, 2009; and Brav, Jiang, and Kim, 2011). The role of institutional investors in the proxy proposal process is also emphasized in John and Klein (1995), Karpoff, Malatesta, and Walkling (1996), Gillan and Starks (2000) and Ertimur, Ferri, and Stubben (2010). Furthermore, the research shows that labor unions are important proposal sponsors for triggering corporate changes (e.g., Prevost, Rao, and Williams, 2012) that do not necessarily increase shareholder value (Agrawal, 2012). Therefore, this evidence alludes to the fact that engagement by influential shareholders could bring about corporate changes. Consequently, corporate managers should carefully evaluate which is more efficient letting these shareholder proposals go to a vote or inviting the proposal sponsors into private negotiations.

Individual shareholders also submit proposals that the management scrutinizes for possible private negotiations. However, these proposals are less of a concern to the management because of the following: The research on voice engagement through shareholder proposals emphasizes that particularly small, individual shareholders - so-called gadfly investors - strive for corporate changes (e.g., Gillan and Starks, 2000). But, the voting outcomes of their proposals are relatively low compared to the voting outcomes of the proposals sponsored by institutional investors (e.g., Chapter 2 of this dissertation). Therefore, the majority of the proposals by individuals do not spur any corporate changes or even performance improvements because these proposals do not gain the support of the important shareholders, such as large institutional investors.

Thomas and Martin (1999) provide an explanation for this phenomenon. They claim that a lot of successful engagement by individual shareholders cannot be observed, at least in the context of executive compensation, because of the collective action problem inherent in every publicly held corporation and the shareholder's "limited capacity to monitor" (Thomas and Martin, 1999, p. 1033). The latter point refers to the fact that compensation policies are notably very complex. Thus, most individual shareholders likely do not understand these complex compensation plans, not to mention whether they are able to evaluate if the current pay practices are appropriate or not (Thomas and Mar- 
tin, 1999). Therefore, proposals by individual shareholders with respect to compensation are generally not successful. I claim that the same argumentation also holds for other topics of shareholder proposals that are filed by individual shareholders, namely CG or CSR proposals. Thus, I derive my first hypothesis:

H3.1: Proposals filed by influential shareholders (i.e., institutional investors or labor unions) are more likely to be withdrawn than proposals filed by individual, private shareholders.

Furthermore, I hypothesize that the ownership structure plays an important role in determining the withdrawal's likelihood. In particular, I claim that the institutional shareholder base correlates positively with the withdrawal's likelihood. This is so, because it is more likely that the management makes the advances to the sponsor when it fears the pressure from a larger institutional shareholder base. The managers are pressured by the large institutional investors because these shareholders can threaten to sell off their stakes, as in the spirit of Admati and Pfleiderer (2009) or Edmans (2009). Assuming a high degree of collaboration between institutional shareholders, I argue that if the institutional sponsors' demands are not fulfilled, other institutional investors exert monitoring power by the impending sell off of their shares. This threat can be carried out especially when no actions are undertaken by the management to implement the requests put forward in the proposal. Consequently, the management fears the adverse effects on the equity-based part of their compensation package and hence, make advances to the sponsor:

\section{H3.2: Institutional ownership is positively related to the withdrawal's likelihood.}

Next to the institutional shareholder base, the ownership stake controlled by the corporate insiders is also an important determinant of the withdrawal's likelihood. Chidambaran and Woidtke (1999) argue that the ownership stake of the corporate insiders influences the manager's level of resistance to corporate changes. In other words, when the managers own a larger fraction of the corporation they are in a dominant position because they feel less pressure from the shareholders (Chidambaran and Woidtke, 1999). The reason for this position is the following: When the managers own a larger fraction of the voting rights, they are more likely to let the proposals go to a vote. Then, the managers simply use their own voting rights to vote against the shareholder proposals and consequently suppress the voting outcomes of those proposals (see Chapter 2 of this dissertation). Hence, I argue that higher insider ownership reduces the withdrawal's likelihood because the managers are more in favor of putting proposals to a vote during the AGM:

H3.3: Insider ownership is negatively correlated to the withdrawal's likelihood. 


\subsection{Data and empirical strategy}

In this section, I discuss the data sources and the empirical strategy that I adopt to investigate the determinants of the withdrawals.

\subsubsection{Shareholder proposal data}

The data on shareholder proposals come from RiskMetrics. RiskMetrics tracks the AGMs of all of the S\&P1500 corporations and records all of the filed shareholder proposals. I examine the time period from 1997 to 2009. After correcting for any duplicates in the proposals, the data set comprises 12,474 proposals that address either CG or CSR topics. The retrieved data on the filed shareholder proposals provide information on whether a proposal was put to a vote, whether it was omitted or whether it was withdrawn by the sponsor. Furthermore, RiskMetrics provides information on the proposal sponsor and the content of the proposals.

Consistent with the second chapter of my dissertation, I classify proposals first into CG and CSR proposals. In a second step, I group the proposals into subcategories based on their topics. A complete list of the proposal topics is provided in Appendix 3.A. I also classify sponsoring shareholders into different sponsor classes; namely institutional investors, individual investors, coordinated activists, and labor unions (consistent with Chapter 2 of my dissertation). Examples for each of those categories can also be found in Appendix 3.A of this chapter.

\subsubsection{Accounting data, firm and ownership information}

Next to the proposal data, I rely on the standard sources for accounting and firm-level financial data. Accounting information for the sample corporations is retrieved from COMPUSTAT. The information on executive compensation and the insider ownership comes from COMPUSTAT's Execucomp, whereas RiskMetrics' governance files provide the corporation-level corporate governance measures. The institutional ownership information for each corporation is retrieved from Thomson Reuters' Institutional Holdings Master File (13f filings). For the institutional ownership, I construct several variables: the total end-of-year fraction of shares owned by all institutions as well as the decomposition into the percentage of shares held by transient, dedicated, and quasi-indexer institutions, following Bushee (1998). I also calculate the Herfindahl-Hirschman Index (HHI) for all institutional holdings.

\subsubsection{Empirical method}

To test my research hypotheses regarding the withdrawal's likelihood, I adopt the following approach. In the empirical analyses, I implement both, firm-level and proposallevel regressions. The main reason for this is that I want to make sure that my results are robust. In the firm-level analysis, I treat every corporation in a given year that displays at 
least one shareholder proposal as one observation. This treatment means that corporations with multiple proposals in a given year appear only once in the data set. On the other hand, the proposal-level analysis treats every single shareholder proposal as a single observation. Hence, the corporations with multiple proposals can appear several times in a given proxy season.

I run logistic regressions for both firm-level and proposal-level analyses of the following type:

$$
\text { Withdrawn } ?_{i, t}=\alpha+\beta_{1}(\text { Ownership })_{i, t}+\beta_{2}(\text { Sponsor })_{i, t}+\beta_{3}(\text { Controls })_{i, t}
$$

In the firm-level analysis, the dependent variable equals unity when the corporation exhibits at least one withdrawn proposal and zero otherwise. In the proposal-level analyses, the dependent variable equals one if the proposal is withdrawn and zero otherwise. The (Ownership) comprises ownership characteristics for corporation $i$ at time $t$. The ownership characteristics contain the insider ownership (measured by the CEO's ownership) and the institutional ownership. I measure the institutional ownership in several ways: My main proxy is the overall and total percentage of stocks held by the institutional investors.

Furthermore, I decompose the institutional ownership into Bushee's (1998) classification of ownership. ${ }^{8}$ Bushee (1998) classifies institutional investors along the institutions" "past investment patterns in the areas of portfolio turnover, diversification, and momentum strategy" (Bushee, 1998, p. 310). This classification results in three groups: transient investors, dedicated investors, and quasi-indexer investors. Generally, transient institutional investors are short-term oriented and follow investment strategies with high portfolio turnover rates, whereas dedicated institutions hold large positions in corporations along with a low portfolio turnover rate (Bushee and Noe, 2000; Bushee, 2001). The quasi-indexer institutions, on the other hand, also have a low portfolio turnover rate but hold more diversified portfolios. Furthermore, the quasi-indexers follow passive investment strategies most of the time that reflect a buy-and-hold investment approach (Bushee and Noe, 2000; Bushee, 2001).

Furthermore, (Sponsor) comprises the proposal sponsor controls (comparable to those in Chidambaran and Woidtke, 1999). In the proposal-level analyses, this is a dummy variable for every sponsor class: institutional investors, individual investors, coordinated activists, and labor unions. Lastly, (Controls) comprises all of the control variables that have been proven in the literature to influence a corporation's exposure to shareholder proposals or the withdrawal's likelihood (e.g., Karpoff, Malatesta, and Walkling, 1996; Chidambaran and Woidtke, 1999). This vector includes the firm size, leverage, firm performance and several corporate governance characteristics.

Before I analyze the withdrawal process in a multivariate setting, I describe the nature and evolution of the withdrawn shareholder proposals.

\footnotetext{
${ }^{8}$ Prof. Bushee's classification of institutional investors is publicly available at: http://acct3.wharton.upenn.edu/faculty/bushee/IIclass.html.
} 


\subsection{The nature and evolution of withdrawn shareholder proposals}

Table 3.1 shows the evolution of filed and withdrawn shareholder proposals from 1997 2009. From this table it becomes apparent that the degree of shareholder engagement increases during the sample period. Especially, the second half displays significantly more filed shareholder proposals. The 2007 proxy season shows the largest number of submitted proposals at 1,156 . The evolution of the withdrawn shareholder proposals displays a similar picture. The number of withdrawn proposals is rather stable during the first five years of the sample period. It fluctuates between 107 withdrawn proposals in 1998 and 183 withdrawn proposals in 2000. However, after 2002, the number and fraction of the withdrawn proposals increases. Most of the withdrawn proposals occurred in 2007 (308 proposals), followed by 279 proposals in 2008. Although the number of filed and withdrawn proposals decreases slightly after 2007, the levels of engagement and withdrawals remain relatively stable thereafter. Hence, I can conclude from my descriptive analysis that shareholders are still using proposals to engage the corporations. Figure 3.2 presents these developments and results graphically.

Table 3.1: The evolution of filed and withdrawn proposals This table shows the number and percentages of filed and withdrawn proposals over the time period from 1997-2009. I distinguish between filed proposals that RiskMetrics recorded and those proposals that have been subsequently withdrawn by the proposal sponsor. The underlying data set has been corrected for duplicates.

\begin{tabular}{|c|c|c|c|c|c|c|}
\hline \multirow[b]{2}{*}{ Year } & \multicolumn{3}{|c|}{ Filed Proposals } & \multicolumn{3}{|c|}{ Withdrawn Proposals } \\
\hline & $\#$ & $\%$ of total & cumul. $\%$ & $\#$ & $\%$ of total & cumul. $\%$ \\
\hline 1997 & 893 & $7.2 \%$ & $7.2 \%$ & 162 & $6.3 \%$ & $6.3 \%$ \\
\hline 1998 & 831 & $6.7 \%$ & $13.8 \%$ & 107 & $4.1 \%$ & $10.4 \%$ \\
\hline 1999 & 792 & $6.3 \%$ & $20.2 \%$ & 112 & $4.3 \%$ & $14.7 \%$ \\
\hline 2000 & 799 & $6.4 \%$ & $26.6 \%$ & 183 & $7.1 \%$ & $21.8 \%$ \\
\hline 2001 & 745 & $6.0 \%$ & $32.5 \%$ & 122 & $4.7 \%$ & $26.5 \%$ \\
\hline 2002 & 803 & $6.4 \%$ & $39.0 \%$ & 179 & $6.9 \%$ & $33.5 \%$ \\
\hline 2003 & 1,082 & $8.7 \%$ & $47.7 \%$ & 220 & $8.5 \%$ & $42.0 \%$ \\
\hline 2004 & 1,086 & $8.7 \%$ & $56.4 \%$ & 227 & $8.8 \%$ & $50.8 \%$ \\
\hline 2005 & 1,027 & $8.2 \%$ & $64.6 \%$ & 231 & $8.9 \%$ & $59.7 \%$ \\
\hline 2006 & 1,008 & $8.1 \%$ & $72.7 \%$ & 196 & $7.6 \%$ & $67.3 \%$ \\
\hline 2007 & 1,156 & $9.3 \%$ & $81.9 \%$ & 308 & $11.9 \%$ & $79.2 \%$ \\
\hline 2008 & 1,140 & $9.1 \%$ & $91.1 \%$ & 279 & $10.8 \%$ & $90.0 \%$ \\
\hline 2009 & 1,112 & $8.9 \%$ & $100.0 \%$ & 259 & $10.0 \%$ & $100.0 \%$ \\
\hline $1997-2003$ & 5,945 & $47.7 \%$ & - & 1,085 & $42.0 \%$ & - \\
\hline 2004-2009 & 6,529 & $52.3 \%$ & - & 1,500 & $58.0 \%$ & - \\
\hline 1997-2009 & 12,474 & $100.0 \%$ & - & 2,585 & $100.0 \%$ & - \\
\hline
\end{tabular}




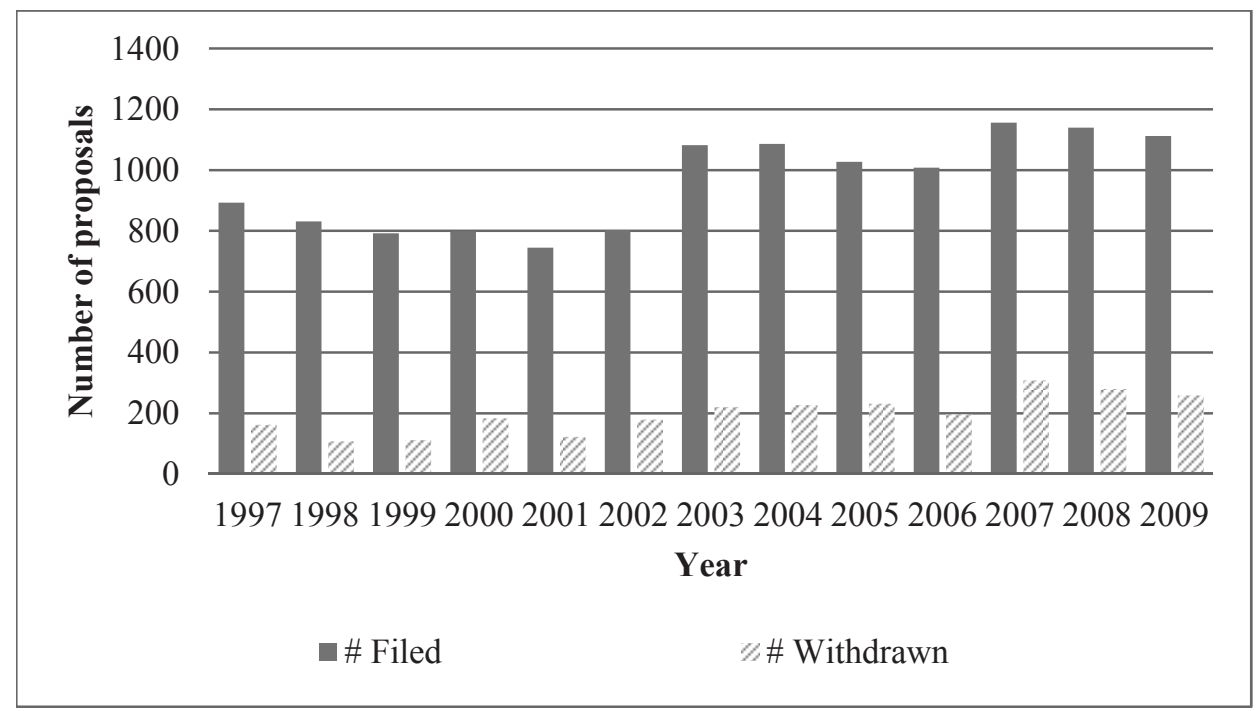

Figure 3.2: Evolution of withdrawn shareholder proposals

This figure shows the number of filed (left bar) and withdrawn proposals (right bar), respectively, over time. The initial sample consists of 12,474 proposals that were filed between 1997 and 2009. Out of this sample of filed proposals, 2,585 were withdrawn prior to the annual meeting, which constitute approximately $20.7 \%$ of the all filed proposals.

Next, I show in which topical areas shareholder engagement and negotiations take place. Table 3.2 presents the details on the nature of the withdrawn proposals over time. Panel A shows that more than one-fifth $(20.7 \%)$ of all of the filed shareholder proposals are withdrawn within the proposal process. However, there are cross-sectional differences with respect to the content of these proposals.

Consistent with Chidambaran and Woidtke (1999), I find that the CSR proposals are withdrawn more often than the CG proposals: $16.8 \%$ compared to $31.2 \%$ respectively. This result holds for every single proxy season during the sample period. This finding alludes to the fact that the corporations are much more responsive to the CSR related proposals than to the $\mathrm{CG}$ proposals. A potential explanation for this finding could be that the CSR proposals have the potential to create negative publicity with respect to environmental and social corporate performance. Thus, the publicity might highlight the implementation of specific social and environmental policies by competitors in the same industry. Hence, the management teams might be more willing to change social or environmental policies and behavior (at least to a certain extent) to settle an agreement with the sponsoring shareholder. Another reason for the higher withdrawal rate of the CSR proposals might also be the fact that the corporations can more easily disclose changes in the CSR domain than in the corporate governance domain through symbolic changes to convince the shareholders to withdraw. Chidambaran and Woidtke (1999) give a related explanation for this finding by attributing the higher withdrawal rate of the proposals that address social issues to the lower costs involved for the corporations to implement 
these recommendations. In a similar vein, the content of CSR proposals could play a role as well. The CSR proposals generally address broader topics, and their requests are often vague, which makes successful negotiations on proposal withdrawals easier for the managers.

To illustrate the evolution of proposal withdrawals, Figure 3.3 plots the percentage of withdrawn proposals over time. ${ }^{9}$ This figure shows that there is always a considerable fraction of proposals that are withdrawn.

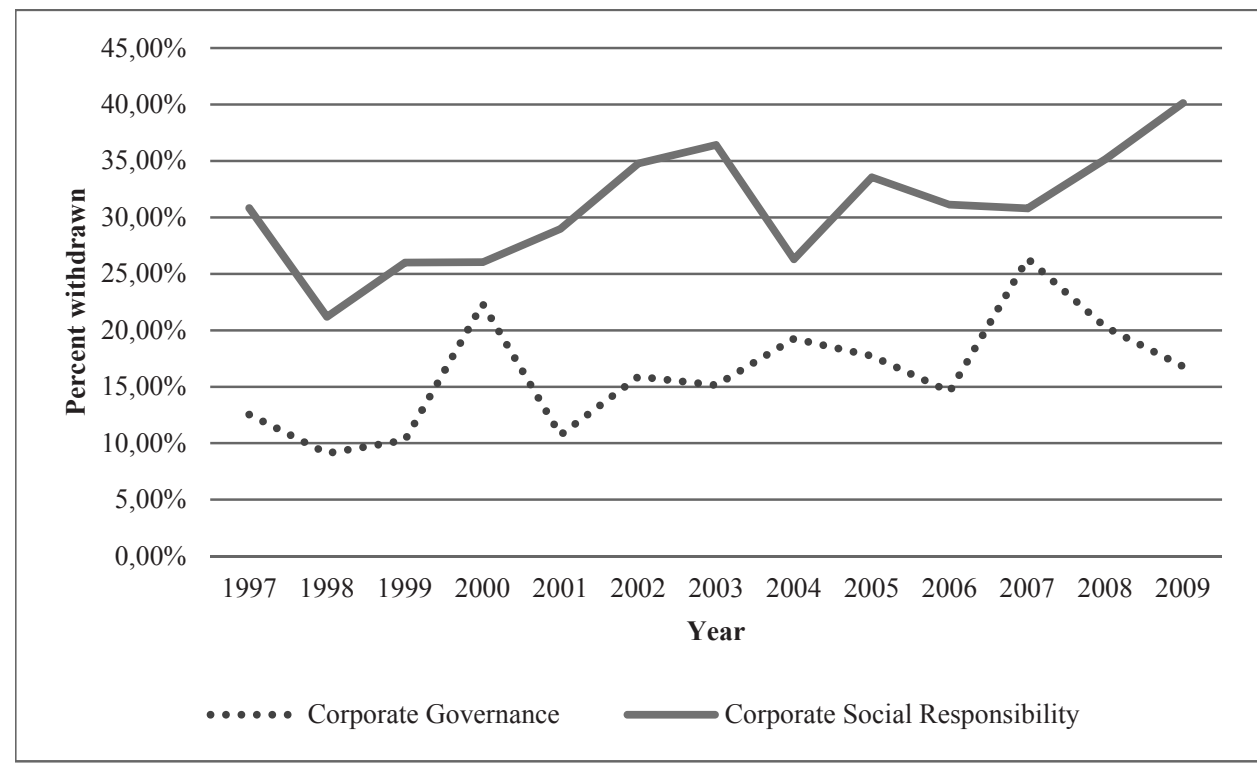

Figure 3.3: Withdrawn proposals by proposal content

This figure shows the percentage of proposals that are withdrawn prior to the annual general meeting. I classify these into crude subcategories of corporate governance and corporate social responsibility.

To shed light on the question of whether the withdrawal rates are associated with sponsor characteristics, Table 3.3 presents the evolution of the withdrawals over time for the different classes of proposal sponsors. Several interesting observations can be made from this table. Over the entire sample period, the proposals that were filed by the labor unions display the highest withdrawal rate $(34.6 \%)$. The institutional investors display the second highest withdrawal rate with $(33.9 \%)$, followed by the coordinated activists (27.7\%). Strikingly, the proposals submitted by the individual shareholders display by far the lowest withdrawal rate $(4 \%)$. The latter sponsor class also displays the lowest withdrawal rates in every year of the sample period. The year 2000 shows a remarkable result: Almost $70 \%$ of all of the filed shareholder proposals by the labor unions were withdrawn in that proxy season.

\footnotetext{
${ }^{9}$ Appendix 3.B provides an overview of the finer sub-classifications of proposal topics.
} 


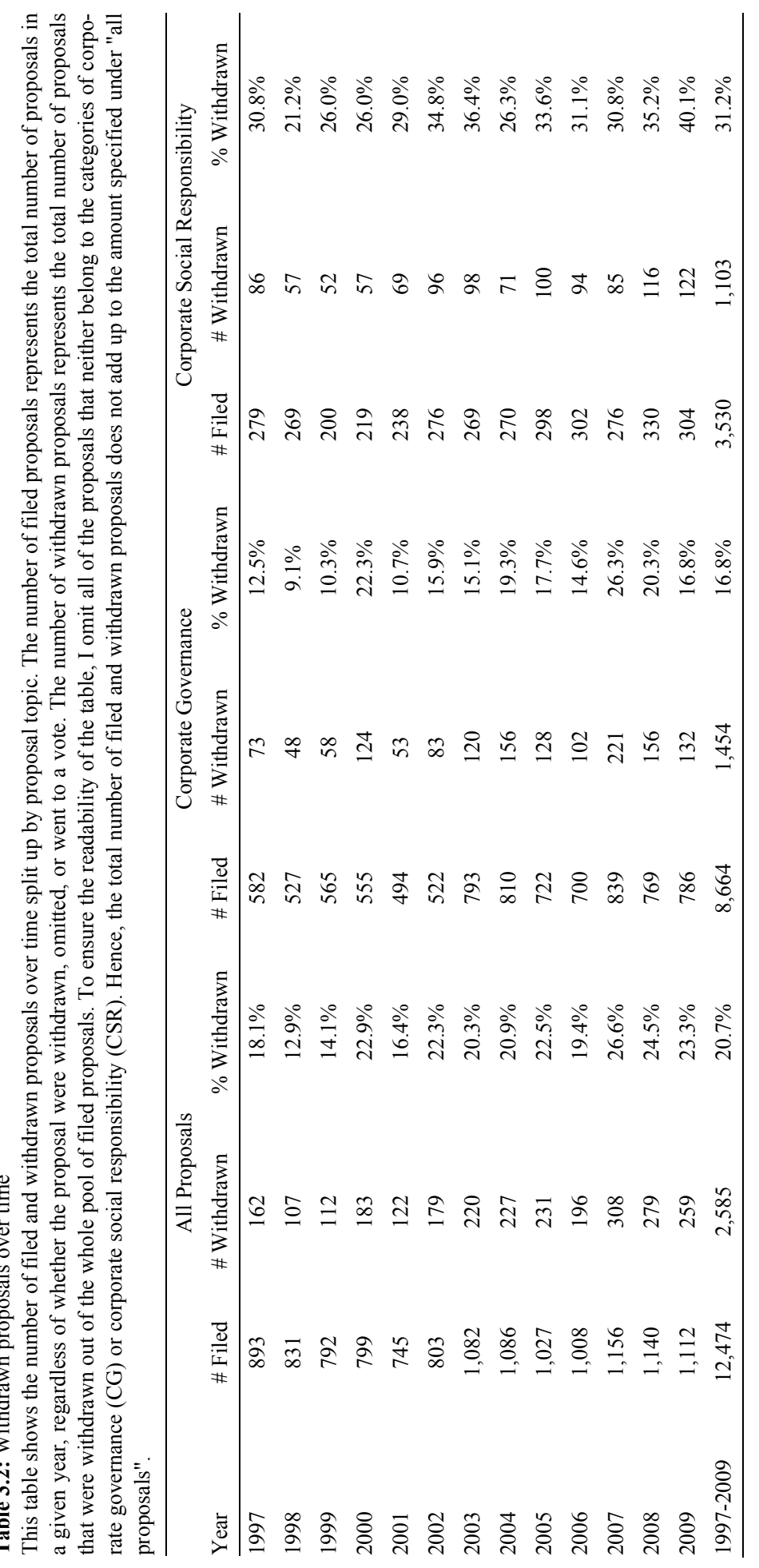




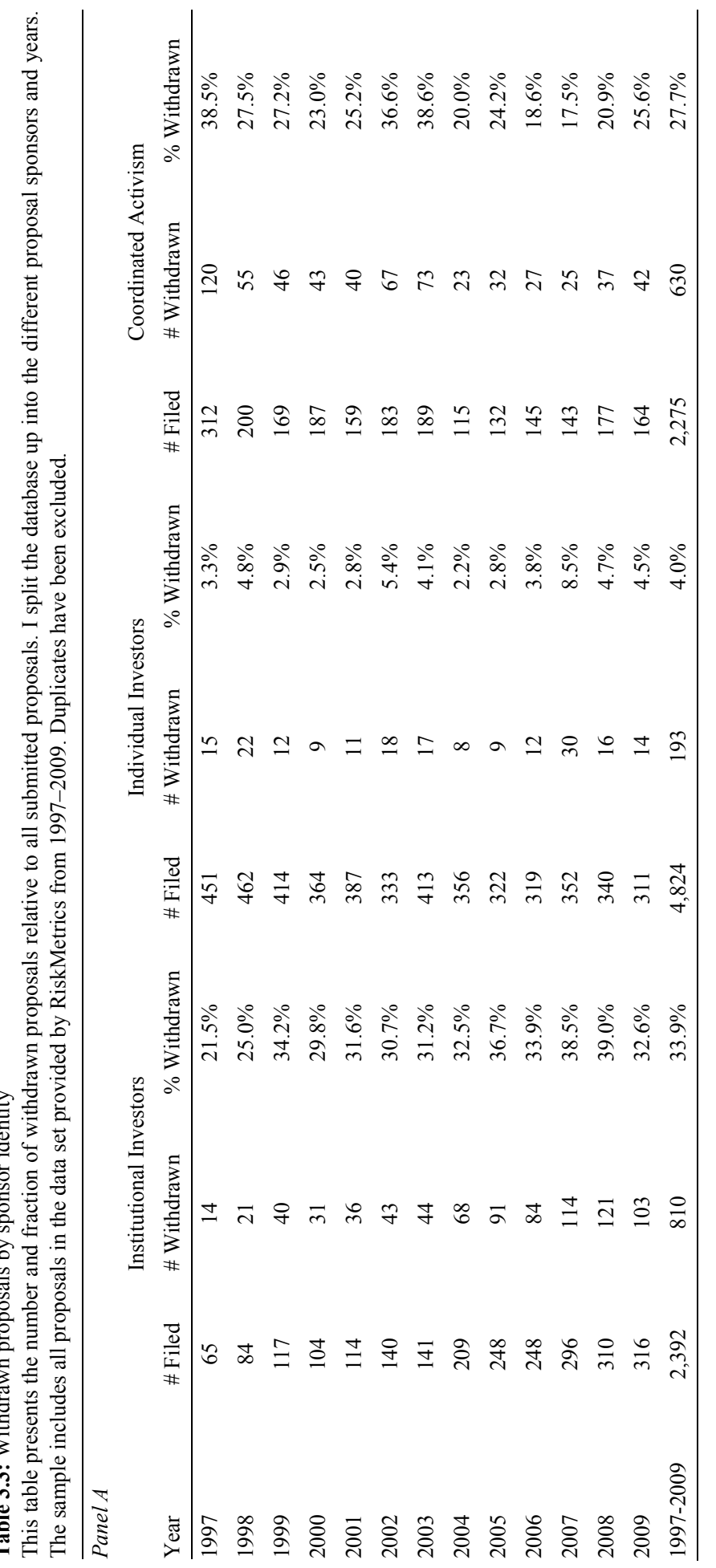




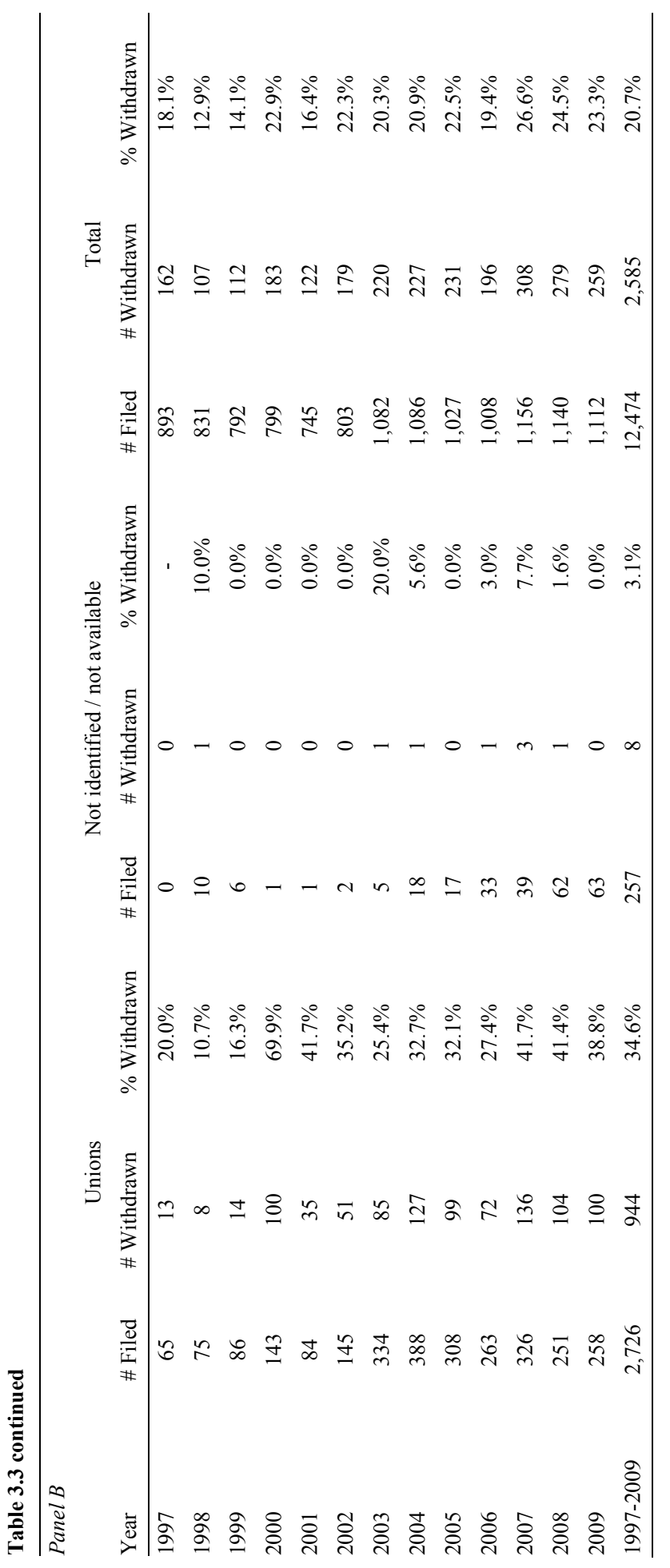




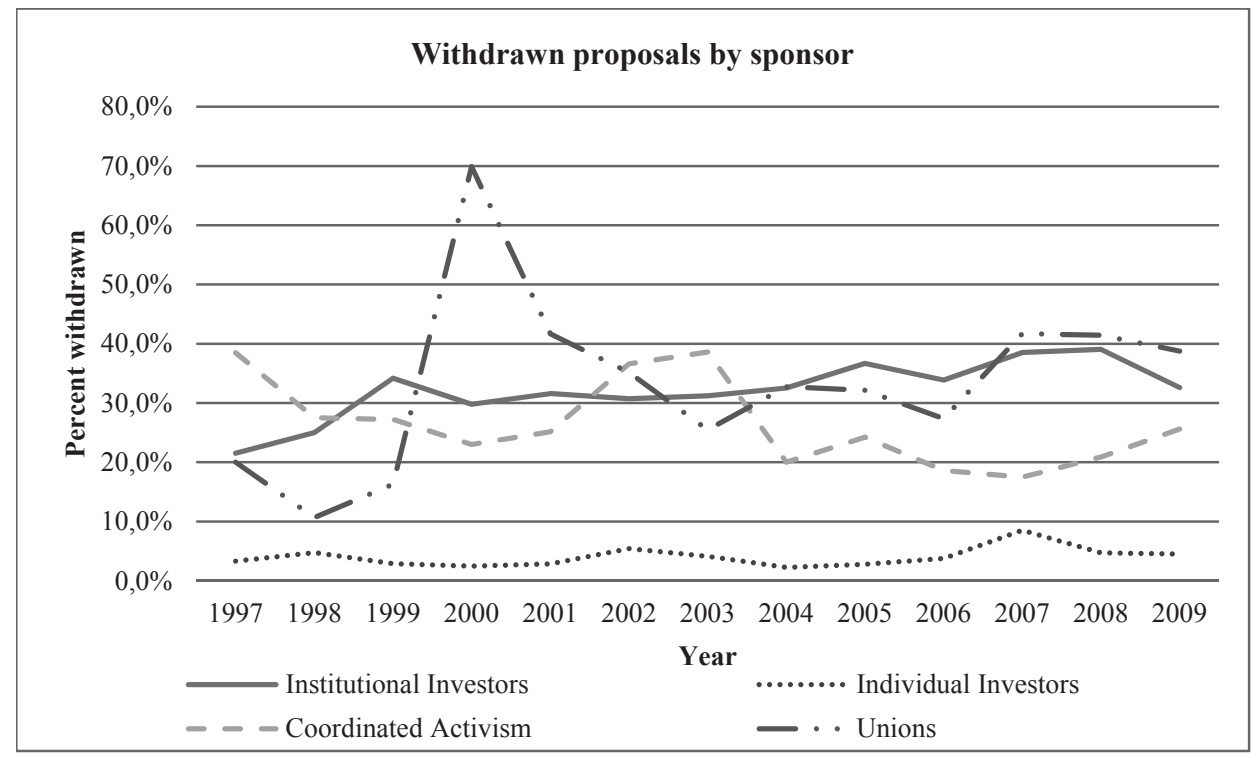

Figure 3.4: Withdrawn proposals split up by sponsor

This figure shows the percentage of proposals that are withdrawn over time. I use the crude sponsor classification to split up the sample: institutional investors, individual investors, coordinated activists, and labor unions.

The descriptive statistics suggest that the more influential shareholders put more pressure on the managers through the negotiations. Figure 3.4 graphically depicts the aforementioned results by plotting the fraction of withdrawn proposals over time and split into the different sponsor classes.

However, one should be careful with the interpretation of these findings, as I do not know yet whether the withdrawal rates of the particular shareholder groups are also influenced by the topics of the filed proposals. Hence, how far the interaction between the sponsor's identity and the proposal's content influences the likelihood that a proposal's withdrawal takes place is not clear. For example, the high withdrawal rates of the institutional investors could be driven by the fact that this shareholder group files more CSR proposals that exhibit, on average, higher withdrawal rates than the CG proposals. Thus, the interaction between the proposal sponsor and the proposal's content needs to be studied as well. 


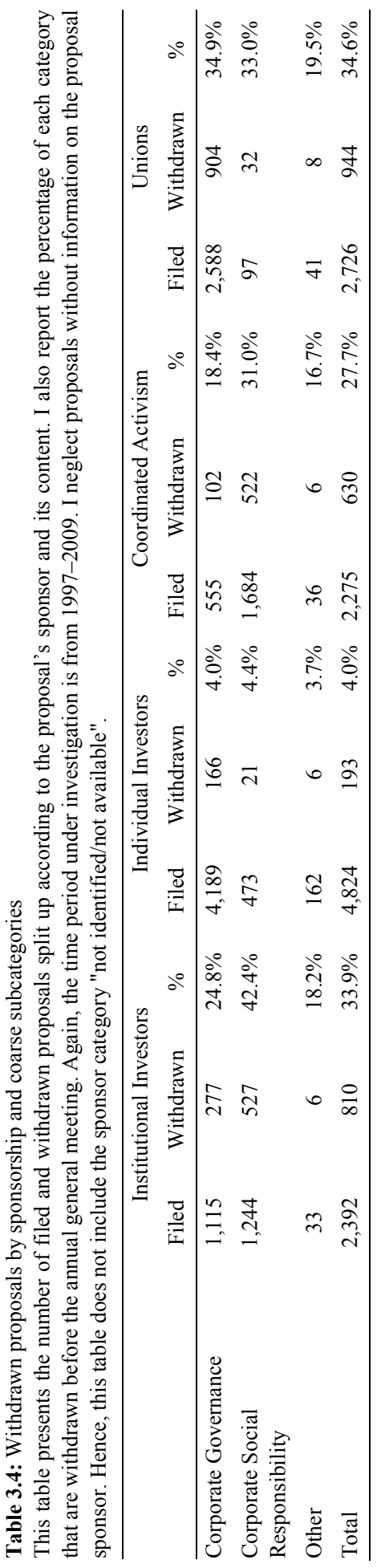


Table 3.4 tackles this specific issue in more detail and provides a clearer picture on the question of who files and withdraws which kinds of proposals. It displays the proposals that are filed and withdrawn by each sponsor group. One sees that, on average, labor unions display the highest withdrawal rates for the CG proposals $(34.9 \%)$, followed by institutional investors $(24.8 \%)$ and coordinated activists $(18.4 \%)$. The picture changes for the CSR proposals: Institutional investors withdraw on average $42.4 \%$ of all filed CSR proposals, whereas labor unions withdraw 33\% of CSR proposals by unions. Individual shareholders display the lowest average withdrawal rates for both the CG and the CSR proposals (4.0\% and $4.4 \%$, respectively).

Notably, all shareholder groups withdraw CSR proposals more often than the CG proposals, which is consistent with the descriptive results mentioned before.

My conclusion is that the descriptive proposal-level analysis shows that the proposals the most likely to be withdrawn are those filed by institutional investors or labor unions. Furthermore, the CSR proposals are, on average, more likely to be withdrawn than the average corporate governance proposal. Overall, I find that shareholders are still filing proposals and entering private negotiations with management, even though managers are not obliged to implement the requests of the shareholder proposals. This observation points to an important monitoring function for the whole proposal process.

\subsection{The determinants of proposal withdrawal}

In this section, I investigate the determinants of the proposal withdrawals in a multivariate setting. I look at both the proposal and the firm level. The distinction is meant to detect whether certain proposal topics are more likely to be withdrawn than others. In the proposal-level analysis, I use a logistic regression framework in which the dependent variable equals one when the proposal was withdrawn and zero otherwise. The firmlevel analysis also includes a logistic regression for the presence of at least one withdrawn proposal in a given proxy season. I first turn to the firm-level analyses.

\subsubsection{Firm-level analysis}

In the following analysis, I treat every corporation that gets at least one proposal as a single observation, even if it receives multiple proposals. Table 3.5 presents the results for the entire sample of withdrawn shareholder proposals regardless of whether a proposal belongs to the CG or the CSR category. I control for firm characteristics, year and industry effects in each regression model. I restrict myself to showing only the variables of major interest in the regression outputs.

In Model 1 of Table 3.5, I control for the institutional ownership level, the HHI of institutional ownership, the interaction between institutional ownership and its HHI, the number of withdrawn proposals in the previous year $t-1$, and the number of proposals filed by the different shareholder groups. Model 2 of Table 3.5 adds the CEO ownership as an independent variable. Lastly, in Model 3 of Table 3.5, I decompose the institutional 
ownership into the percentage of shares held by the transient, dedicated, and the quasiindexer institutions as in Bushee (1998).

The results of Model 1 allude to the importance of the ownership structure in the withdrawal process. I find that the institutional ownership is positively and significantly related to the withdrawal's likelihood. In Model 1, the coefficient of 1.349 on the institutional ownership variable implies that a one standard deviation increase in the institutional ownership increases the corporation's odds of displaying one withdrawn shareholder proposal by $23.7 \%$. I find a similar result in Model 2, even when I add the control for the CEO ownership. The significant and positive coefficient on the institutional ownership variable can be interpreted as follows: If corporations have a higher share of institutional ownership, then the management is more likely to make advances to the proposal sponsor irrespective of whether an individual, union, institution or any other interest groups is filing the proposal. The reason for this behavior is because the managers are experiencing the exit threat from institutions. As Edmans (2009) and Admati and Pfleiderer (2009) point out, the institutional investors can discipline managers by threatening to sell their stakes, which implies adverse effects for the managers' compensation. Hence, to circumvent institutional shareholders from adopting the Wall Street Walk, the managers are more willing to reach a compromise that in the end leads to a withdrawal of the proposal when there is high institutional ownership. Overall, the positive relation between institutional ownership and the withdrawal's likelihood supports hypothesis H3.2. 


\section{CHAPTER 3}

Table 3.5: Determinants of proposal withdrawal

This table presents the results of logistic firm-level regressions. The dependent variable equals one if a corporation displays at least one withdrawn shareholder proposal in a proxy season regardless of the proposal's topic. In the different models presented here, I make use of different control variables. The firm characteristic control variables are total assets, net-profit-margin, leverage, capital expenditures and the dividend yield. The corporate governance control vector includes dummy variables for the presence of each of the following governance provisions: classified board, dual class stock, poison pill, golden parachute. Further, I control for year and industry effects in all models, and all regression models also include a constant. All continuous independent variables are winsorized at 1 and $99 \%$, respectively. The $* * *, * *$, and $*$ denote statistical significance at the $1 \%, 5 \%$, and $10 \%$ levels respectively. Robust p-values are in parentheses.

\begin{tabular}{|c|c|c|c|}
\hline & Model 1 & Model 2 & Model 3 \\
\hline Institutional Ownership & $\begin{array}{l}1.349 * * * \\
(0.008)\end{array}$ & $\begin{array}{l}1.274 * * \\
(0.019)\end{array}$ & \\
\hline Ownership Dedicated Institutions & & & $\begin{array}{c}0.178 \\
(0.835)\end{array}$ \\
\hline Ownership Quasi-Indexer Institutions & & & $\begin{array}{l}1.685^{* * * *} \\
(0.003)\end{array}$ \\
\hline Ownership Transient Institutions & & & $\begin{array}{c}0.631 \\
(0.404)\end{array}$ \\
\hline CEO Ownership & & $\begin{array}{l}-4.495 * * * \\
(0.003)\end{array}$ & $\begin{array}{l}-4.395 * * * \\
(0.004)\end{array}$ \\
\hline HHI of Institutional Ownership & $\begin{array}{c}6.939 \\
(0.688)\end{array}$ & $\begin{array}{c}8.276 \\
(0.647)\end{array}$ & $\begin{array}{c}8.857 \\
(0.624)\end{array}$ \\
\hline Inst. Ownership * HHI inst. Ownership & $\begin{array}{r}-10.697 \\
(0.609)\end{array}$ & $\begin{array}{r}-11.022 \\
(0.613)\end{array}$ & $\begin{array}{l}-8.933 \\
(0.672)\end{array}$ \\
\hline \# Withdrawn Proposals t-1 & $\begin{array}{c}0.119 * \\
(0.050)\end{array}$ & $\begin{array}{c}0.108 * \\
(0.082)\end{array}$ & $\begin{array}{c}0.110 * \\
(0.078)\end{array}$ \\
\hline \# Proposals filed by Institutions & $\begin{array}{l}0.745^{* * *} \\
(0.000)\end{array}$ & $\begin{array}{l}0.745^{* * *} \\
(0.000)\end{array}$ & $\begin{array}{l}0.750 * * * \\
(0.000)\end{array}$ \\
\hline \# Proposals filed by Individuals & $\begin{array}{l}-0.104 * * * \\
(0.009)\end{array}$ & $\begin{array}{l}-0.106 * * \\
(0.010)\end{array}$ & $\begin{array}{l}-0.109 * * * \\
(0.008)\end{array}$ \\
\hline \# Proposals filed by Coordinated & $\begin{array}{l}0.448 * * * \\
(0.000)\end{array}$ & $\begin{array}{l}0.433 * * * \\
(0.000)\end{array}$ & $\begin{array}{l}0.431 * * * \\
(0.000)\end{array}$ \\
\hline \# Proposals filed by Unions & $\begin{array}{l}0.638^{* * *} \\
(0.000)\end{array}$ & $\begin{array}{l}0.636^{* * *} \\
(0.000)\end{array}$ & $\begin{array}{l}0.636 * * * \\
(0.000)\end{array}$ \\
\hline Firm Characteristics Controls & yes & yes & yes \\
\hline Corporate Governance Controls & yes & yes & yes \\
\hline Number of Observations & 3,386 & 3,221 & 3,221 \\
\hline Pseudo R-squared & 0.159 & 0.164 & 0.165 \\
\hline
\end{tabular}


To investigate which institutional investor category is driving the positive relation between the withdrawal's likelihood and the institutional ownership, I use the institutional investor classification of Bushee (1998) in Model 3 of Table 3.5. There, I decompose the institutional ownership into the stakes held by the transient, quasi-indexer, and the dedicated institutions. My results show that the ownership by the quasi-indexer institutions is positively (1.685) related to the withdrawal's likelihood (1\% significance level). Economically, this relation means that a one standard deviation increase in the quasi-indexer stock ownership increases the odds of having at least one withdrawn proposal by $19.5 \%$, holding all remaining variables constant. Apparently, the ownership of dedicated and transient institutional investors does not affect the withdrawal's likelihood. Hence, my results imply that the long-term oriented and passive institutions drive the positive relation between the institutional holdings and the withdrawal's likelihood, that is, corporations become more responsive to shareholder proposals as soon as more long-term oriented institutions are part of the shareholder base.

The results of Models 1-3 of Table 3.5 also show that the concentration level of institutional ownership, the HHI of institutional ownership, is not significantly related to the likelihood of withdrawal. Therefore, for private negotiations to be successful, a concentrated institutional shareholder base is not necessary. It is the size of the stake owned by the institutions that influences the withdrawal's likelihood.

Concerning insider ownership, I find a significantly negative relation between CEO ownership and the withdrawal's likelihood in Models 2 and 3. The coefficient is equal to (-4.495) in Model 2 and (-4.395) in Model 3, implying that a one standard deviation increase in CEO ownership reduces the odds that a corporation exhibits at least one withdrawn proposal by $13.5 \%$ and $13.2 \%$, respectively. This finding implies that the insider ownership reduces the probability of the proposal's withdrawal. This result is consistent with earlier evidence provided by Chidambaran and Woidtke (1999). The negative correlation between the insider ownership and the withdrawal's likelihood means that managers are more likely to let proposals go to a vote when their stake in the corporation is higher. In this case, managers do not necessarily have to make advances to sponsors to achieve a withdrawal. The more voting power the managers possess, the more likely it is that the managers resist proposals, and hence, let proposals go to a vote during the AGM (Chidambaran and Woidtke, 1999). Consequently, the corporate insiders can then use their own voting rights to vote against these proposals during AGMs (see Chapter 2 of this dissertation).

In Section 3.2, I discuss the dynamics of the entire withdrawal process. Because voice engagement of the shareholders is a continuous process, I argue that the withdrawal likelihood of the proposals today can also be influenced by the number of withdrawn proposals of the preceding proxy season. If this is true, then the corporations that offer shareholders a satisfactory compromise in private negotiations this year are also more likely to reach compromises during negotiations in the next year. The empirical results in Table 3.5 support this claim: I find a positive relation between the number of withdrawn proposals in year $t-1$ and the withdrawal likelihood of proposals in year $t_{0}$. For example, the results of Model 3 in Table 3.5 imply that one additional withdrawn shareholder 
proposal in $t-1$ increases the likelihood that a corporation also displays at least one withdrawn shareholder proposal in $\mathrm{t}_{0}$ by $11.6 \%$.

Models 1-3 also disclose that the extent to which corporations are exposed to engagement of certain shareholders also influences the withdrawal's likelihood. The number of proposals filed by individual shareholders significantly reduces the withdrawal's likelihood. Holding all other variables constant, this result implies that one more shareholder proposal filed by individual shareholders reduces the odds that a corporation displays at least one withdrawn proposal by $10.4 \%$. In contrast, the number of proposals filed by all other shareholder groups has a positive and significant effect on the withdrawal's likelihood. This result stems from the fact that proposals of individual shareholders are withdrawn less often per se. Stated differently, the more proposals that are filed by more influential shareholder groups, the more likely it is that at least one of those proposals is withdrawn. I argue that these results are in line with hypothesis H3.1 that proposals filed by more influential shareholders are more likely to be withdrawn.

On an aggregate level, I conclude that my empirical findings are in line with my research hypotheses $H 3.1, H 3.2$, and $H 3.3$. I find supportive evidence that the proposals filed by more influential shareholders (i.e., institutions or labor unions) are more likely to be withdrawn in the proposal process. However, this result has to be interpreted with caution as I just control for the number of proposals filed by the different shareholder groups. My proposal-level analysis shows in more detail which role the proposal's sponsor plays in the withdrawal process. The empirical results also support my second research hypothesis $H 3.2$ because the withdrawal's likelihood increases with the institutional ownership. This increase implies that managers are feeling pressure from the powerful shareholder groups and are thus more likely to reach an agreement with the sponsoring shareholders. Further, I also show that the insider ownership is negatively related to the withdrawal's likelihood, which is consistent with my last research hypothesis H3.3. For the firm-level analysis, I do not find evidence that transient institutional investors especially influence the withdrawal's likelihood. Rather, I find a positive and significant relation between the ownership stake held by the quasi-indexer institutions and the withdrawal's likelihood.

As mentioned, more than half of all of the withdrawn proposals belong to the CG category. Therefore, I now investigate whether the aforementioned results are driven by this proposal topic. I do so by investigating two subsamples of withdrawn shareholder proposals separately, namely CG and CSR proposals. In the following, I first investigate the determinants of the CG proposal withdrawals. Table 3.6 presents the results for those withdrawals. 
Table 3.6: Determinants of CG proposal withdrawal

This table presents the results of logistic firm-level regressions. The dependent variable equals one if a firm displays at least one withdrawn corporate governance (CG) proposal, and zero otherwise. I focus only on those firms that display at least one filed CG proposal in a given year. In the different models presented here, I make use of different control variables. The firm characteristics control variables are total assets, net-profit-margin, leverage, capital expenditures and the dividend yield. The CG control vector includes the dummy variables for the presence of each of the following governance provisions: classified board, dual class stock, poison pill, golden parachute. Further, I control for year and industry effects in all models, and all regression models also include a constant. All independent variables are winsorized at 1 and $99 \%$, respectively. The ***,**, and * denote statistical significance at the $1 \%, 5 \%$, and $10 \%$ levels respectively. Robust p-values are in parentheses.

\begin{tabular}{|c|c|c|c|}
\hline & Model 1 & Model 2 & Model 3 \\
\hline \multirow[t]{2}{*}{ Institutional Ownership } & $1.444 * *$ & $1.247 *$ & \\
\hline & $(0.032)$ & $(0.081)$ & \\
\hline \multirow[t]{2}{*}{ Ownership Dedicated Institutions } & & & 0.502 \\
\hline & & & $(0.647)$ \\
\hline \multirow[t]{2}{*}{ Ownership Quasi-Indexer Institutions } & & & $1.634 * *$ \\
\hline & & & $(0.027)$ \\
\hline \multirow[t]{2}{*}{ Ownership Transient Institutions } & & & 0.639 \\
\hline & & & $(0.508)$ \\
\hline \multirow[t]{2}{*}{ CEO Ownership } & & $-8.322 * * *$ & $-8.249 * * *$ \\
\hline & & $(0.000)$ & $(0.000)$ \\
\hline \multirow[t]{2}{*}{ HHI of Institutional Ownership } & 24.040 & 29.915 & 29.781 \\
\hline & $(0.253)$ & $(0.171)$ & $(0.170)$ \\
\hline \multirow[t]{2}{*}{ Inst. Ownership * HHI Inst. Ownership } & -29.788 & -34.344 & -32.457 \\
\hline & $(0.245)$ & $(0.195)$ & $(0.201)$ \\
\hline \multirow[t]{2}{*}{ \# Withdrawn CG Proposals t-1 } & $0.144 *$ & 0.136 & 0.136 \\
\hline & $(0.077)$ & $(0.101)$ & $(0.101)$ \\
\hline \multirow[t]{2}{*}{ \# CG Proposals filed by Institutions } & $0.718 * * *$ & $0.727 * * *$ & $0.728 * * *$ \\
\hline & $(0.000)$ & $(0.000)$ & $(0.000)$ \\
\hline \multirow[t]{2}{*}{ \# CG Proposals filed by Individuals } & $-0.084 *$ & $-0.101 *$ & $-0.104 * *$ \\
\hline & $(0.092)$ & $(0.055)$ & $(0.047)$ \\
\hline \multirow[t]{2}{*}{ \# CG Proposals filed by Coordinated } & $0.260 *$ & $0.253 *$ & $0.258 *$ \\
\hline & $(0.076)$ & $(0.088)$ & $(0.084)$ \\
\hline \multirow[t]{2}{*}{ \# CG Proposals filed by Unions } & $0.905 * * *$ & $0.908 * * *$ & $0.908 * * *$ \\
\hline & $(0.000)$ & $(0.000)$ & $(0.000)$ \\
\hline Firm Characteristics Controls & yes & yes & yes \\
\hline Corporate Governance Controls & yes & yes & yes \\
\hline Number Of Observations & 2,680 & 2,558 & 2,558 \\
\hline Pseudo R-squared & 0.180 & 0.186 & 0.187 \\
\hline
\end{tabular}

In general, the results for the CG proposals are remarkably similar to the results for the entire sample. The institutional ownership increases the withdrawal likelihood of the CG proposals, and the CEO ownership decreases the withdrawal's likelihood. The economic 
magnitudes of these effects are slightly stronger than the ones for the entire sample of proposals. Holding all other control variables constant in Model 2, a one standard deviation increase in the institutional ownership (CEO ownership) increases (decreases) the odds that a corporation displays a withdrawn CG proposal by $21.1 \%(21.6 \%)$. Furthermore, my previous finding that the ownership stake of the quasi-indexer institutions drives the significant relation between the institutional ownership and the withdrawal's likelihood still holds for the CG proposals.

The number of withdrawn CG proposals during year $t-1$ is only significantly and positively related to corporate governance proposal withdrawal in year $t_{0}$ in Model 1 . In the remaining models, there is no significant relation between the number of withdrawn CG proposals in year $t-1$ and year $t_{0}$. This finding means that the number of past withdrawn CG proposals is not a good indicator of successful negotiations in the future.

Next, I study the withdrawal likelihood of CSR proposals. Table 3.7 displays the results of the three different logistic regression models. Compared to the results for the overall sample and the subsample of the CG proposals, I find very different results for the withdrawal likelihood of CSR proposals. As displayed in the three models in Table 3.7, the ownership structure does not affect the likelihood that a corporation displays at least one withdrawn CSR proposal in a given year. I do not find a positive relation between any of the institutional ownership variables, nor do I find a significant relation between the CEO ownership and the withdrawal's likelihood. The latter result can be interpreted as the corporate insiders being less concerned about the CSR proposals in private negotiations. As I have shown in the descriptive proposal-level analyses, the CSR proposals display much higher withdrawal rates than the CG proposals. My multivariate findings mean that, irrespective of the stake owned by the corporate insiders, the shareholders withdraw their CSR proposals relatively more often than the CG proposals. This finding alludes to the fact that the managers make certain concessions to the shareholders more easily when faced with a CSR proposal. The reason is that any changes with respect to the CSR policies are easier to implement and that managers can expect fewer adverse monetary consequences.

In contrast to my previous findings for the CG proposals, the results in Table 3.7 emphasize the influence of the past year's number of withdrawn CSR proposals. I find a positive and significant relation between the number of withdrawn CSR proposals in $t-1$ and the likelihood of their withdrawals in year $t_{0}$. This result is consistently positive and significant in all three models of Table 3.7. The economic magnitude of this effect is comparable for each model. One more withdrawn CSR proposal in $t-1$ increases the odds of having at least one withdrawn CSR proposal in $\mathrm{t}_{0}$ by 28.2\% (Model 1), 27.3\% (Model 2 ), and $27.2 \%$ (Model 3) respectively. It implies that the corporations that make concessions to sponsoring shareholders in a given year are also more likely to exhibit withdrawn CSR proposals in the following year. 
Table 3.7: Determinants of CSR proposal withdrawal

This table presents the results of logistic firm-level regressions. The dependent variable equals one if a firm displays at least one withdrawn corporate social responsibility (CSR) proposal, and zero otherwise. I focus only on those firms that display at least one filed CSR proposal in a given year. In the different models presented here, I make use of different control variables. The firm characteristics control variables are total assets, net-profit-margin, leverage, capital expenditures and the dividend yield. The corporate governance (CG) control vector includes the dummy variables for the presence of each of the following governance provisions: classified board, dual class stock, poison pill, golden parachute. Further, I control for year and industry effects in all models and all regression models also include a constant. All independent variables are winsorized at 1 and $99 \%$, respectively. The $* * *, * *$, and $*$ denote statistical significance at the $1 \%, 5 \%$, and $10 \%$ levels respectively. Robust p-values are in parentheses.

\begin{tabular}{|c|c|c|c|}
\hline & Model 1 & Model 2 & Model 3 \\
\hline \multirow[t]{2}{*}{ Institutional Ownership } & 0.793 & 0.730 & \\
\hline & $(0.258)$ & $(0.338)$ & \\
\hline \multirow[t]{2}{*}{ Ownership Dedicated Institutions } & & & 0.277 \\
\hline & & & $(0.817)$ \\
\hline \multirow[t]{2}{*}{ Ownership Quasi-Indexer Institutions } & & & 1.176 \\
\hline & & & $(0.163)$ \\
\hline \multirow[t]{2}{*}{ Ownership Transient Institutions } & & & 0.628 \\
\hline & & & $(0.574)$ \\
\hline \multirow[t]{2}{*}{ CEO Ownership } & & -1.886 & -1.755 \\
\hline & & $(0.345)$ & $(0.381)$ \\
\hline \multirow[t]{2}{*}{ HHI of Institutional Ownership } & -8.078 & -6.840 & 0.053 \\
\hline & $(0.775)$ & $(0.819)$ & $(0.999)$ \\
\hline \multirow[t]{2}{*}{ Inst. Ownership * HHI inst. Ownership } & 14.337 & 13.733 & 6.371 \\
\hline & $(0.668)$ & $(0.698)$ & $(0.860)$ \\
\hline \multirow[t]{2}{*}{ \# Withdrawn CSR Proposals t-1 } & $0.248 * *$ & $0.241 * *$ & $0.241 * *$ \\
\hline & $(0.032)$ & $(0.039)$ & $(0.039)$ \\
\hline \multirow[t]{2}{*}{ \# CSR Proposals filed by Institutions } & $0.924 * * *$ & $0.908 * * *$ & $0.917 * * *$ \\
\hline & $(0.000)$ & $(0.000)$ & $(0.000)$ \\
\hline \multirow[t]{2}{*}{ \# CSR Proposals filed by Individuals } & -0.174 & -0.169 & -0.164 \\
\hline & $(0.182)$ & $(0.201)$ & $(0.215)$ \\
\hline \multirow[t]{2}{*}{ \# CSR Proposals filed by Coordinated } & $0.341 * * *$ & $0.325 * * *$ & $0.328 * * *$ \\
\hline & $(0.000)$ & $(0.000)$ & $(0.000)$ \\
\hline \multirow[t]{2}{*}{ \# CSR Proposals filed by Unions } & 0.154 & 0.154 & 0.156 \\
\hline & $(0.573)$ & $(0.573)$ & $(0.567)$ \\
\hline Firm Characteristics Controls & yes & yes & yes \\
\hline Corporate Governance Controls & yes & yes & yes \\
\hline Number of Observations & 1,603 & 1,523 & 1,523 \\
\hline Pseudo R-squared & 0.085 & 0.085 & 0.086 \\
\hline
\end{tabular}

Moreover, the empirical results of Models 1 to 3 of Table 3.7 indicate that only the number of proposals filed by the coordinated activists and the institutional investors signifi- 
cantly increase the likelihood of having at least one withdrawn CSR proposal. Hence, the coordinated activists have a significant influence on the withdrawal likelihood of CSR proposals.

I find supporting evidence for my hypotheses H3.1, H3.2, and H3.3. I infer from my firm-level analyses that both the institutional and the insider ownership are the major determinants for the proposal withdrawals. This finding implies that a more powerful shareholder base in terms of institutional shareholders strengthens the bargaining position of the proposal sponsors, which eventually leads to a higher likelihood of proposal withdrawal. But, the insider and institutional ownerships both do not affect the withdrawal likelihood of CSR proposals. For the CSR proposal's withdrawal likelihood, a major determinant represents the number of the past year's withdrawn CSR proposals.

\subsubsection{Proposal-level analysis}

I now turn to the proposal-level analyses. Here, I treat every proposal as a single observation. The results are in Tables 3.8 to 3.10. Table 3.8 presents the different models for the withdrawal's likelihood for any shareholder proposal irrespective of the proposal's topic. I add the same explanatory variables as in the firm-level analysis. In addition, I control for the effects of the interactions between my institutional ownership proxies and the proposal sponsorship on the withdrawal's likelihood. This is possible for the proposal-level analysis only, because I can then control for the fact that certain individual proposals are filed by certain shareholders.

Compared to the firm-level analysis, the addition of these control variables slightly changes the results. The results of all four models in Table 3.8 allude to the importance of the institutional ownership as one of the major drivers of the proposal's withdrawal likelihood. On an aggregate level, Model 1 discloses that the institutional ownership is still positively and significantly related to the withdrawal's likelihood for any kind of shareholder proposals. In economic terms, the coefficient of (0.855) on Institutional ownership implies that a one standard deviation increase in the institutional ownership increases the odds that a proposal gets withdrawn by $13.5 \%$, all else constant.

In Model 2, I add a control variable for the interaction between the institutional sponsorship and the institutional ownership. The reason for the inclusion of this interaction term is that a proposal filed by an institutional investor with a corporation that is characterized by a relatively large institutional ownership share might be even more likely to be withdrawn because the sponsoring shareholder is supported by a large institutional shareholder base. Further, private talks among the different institutions might have gone on prior to the actual filing of the proposal. Hence, the managers might be aware of the multiplicative power of these proposals and are thus more likely to make concessions to the shareholders. My empirical results support this idea. The interaction term turns out significant and positive that means the withdrawal's likelihood increases when the institutional ownership is high and the proposal's sponsor is an institutional investor. Consequently, the addition of this control variable takes up all of the significant 
effect from the institutional ownership itself, which implies that the presence of an institutional sponsor is crucial to affect and to increase the withdrawal's likelihood.

Table 3.8: Determinants of proposal withdrawal (proposal-level)

This table presents proposal-level logistic regressions where the dependent variable equals one if the proposal is withdrawn and zero otherwise. No distinction is made between the CG and the CSR proposals. All models control for firm's financial and governance characteristics. The firm characteristics control variables are total assets, net-profit-margin, leverage, capital expenditures and the dividend yield. The CG control vector includes the dummy variables for the presence of each of the following governance provisions: classified board, dual class stock, poison pill, golden parachute. Further, I control for year and industry effects in all models, and all regression models also include a constant. All independent variables are winsorized at 1 and $99 \%$, respectively. The $* * *, * *$, and $*$ denote statistical significance at the $1 \%, 5 \%$, and $10 \%$ levels respectively. Robust p-values are in parentheses.

\begin{tabular}{|c|c|c|c|c|}
\hline & Model 1 & Model 2 & Model 3 & Model 4 \\
\hline \multirow[t]{2}{*}{ Institutional Ownership } & $0.855^{* *}$ & 0.497 & & \\
\hline & $(0.032)$ & $(0.230)$ & & \\
\hline \multirow[t]{2}{*}{ Institutional Sponsor * Institutional Ownership } & & $1.360 * * *$ & & \\
\hline & & $(0.003)$ & & \\
\hline \multirow[t]{2}{*}{ Ownership Dedicated Institutions } & & & 0.595 & 0.944 \\
\hline & & & $(0.368)$ & $(0.212)$ \\
\hline \multirow[t]{2}{*}{ Ownership Quasi-Indexer Institutions } & & & $1.300 * * *$ & 0.766 \\
\hline & & & $(0.004)$ & $(0.123)$ \\
\hline \multirow[t]{2}{*}{ Ownership Transient Institutions } & & & 0.336 & -0.387 \\
\hline & & & $(0.584)$ & $(0.588)$ \\
\hline \multirow{3}{*}{$\begin{array}{l}\text { Inst. Sponsor * Ownership Dedicated } \\
\text { Institutions }\end{array}$} & & & & -0.489 \\
\hline & & & & \\
\hline & & & & $(0.641)$ \\
\hline \multirow{3}{*}{$\begin{array}{l}\text { Inst. Sponsor * Ownership Quasi-Indexer } \\
\text { Institutions }\end{array}$} & & & & $1.949 * * *$ \\
\hline & & & & \\
\hline & & & & $(0.004)$ \\
\hline \multirow[t]{2}{*}{ Inst. Sponsor * Ownership Transient Institutions } & & & & $2.192 * *$ \\
\hline & & & & $(0.024)$ \\
\hline \multirow[t]{2}{*}{ CEO Ownership } & $-4.251 * * *$ & $-4.167 * * *$ & $-4.151 * * *$ & $-4.104 * * *$ \\
\hline & $(0.001)$ & $(0.001)$ & $(0.001)$ & $(0.002)$ \\
\hline \multirow[t]{2}{*}{ \# Withdrawn Proposals T-1 } & 0.033 & 0.034 & 0.032 & 0.033 \\
\hline & $(0.316)$ & $(0.301)$ & $(0.329)$ & $(0.315)$ \\
\hline \multirow[t]{2}{*}{ HHI of Institutional Ownership } & 4.779 & 9.803 & 5.980 & 12.074 \\
\hline & $(0.746)$ & $(0.511)$ & $(0.694)$ & $(0.431)$ \\
\hline \multirow[t]{2}{*}{ Inst. Ownership * HHI Inst. Ownership } & -5.771 & -11.588 & -7.442 & -14.783 \\
\hline & $(0.740)$ & $(0.510)$ & $(0.670)$ & $(0.402)$ \\
\hline \multirow[t]{2}{*}{ Institutional Sponsor? } & $2.090 * * *$ & $1.110^{* * *}$ & $2.093 * * *$ & $0.932 * *$ \\
\hline & $(0.000)$ & $(0.002)$ & $(0.000)$ & $(0.013)$ \\
\hline \multirow[t]{2}{*}{ Coordinated Activist Sponsor? } & $1.545^{* * *}$ & $1.549 * * *$ & $1.547 * * *$ & $1.552 * * *$ \\
\hline & $(0.000)$ & $(0.000)$ & $(0.000)$ & $(0.000)$ \\
\hline \multirow[t]{2}{*}{ Union Sponsor? } & $2.419 * * *$ & $2.442 * * *$ & $2.419 * * *$ & $2.445 * * *$ \\
\hline & $(0.000)$ & $(0.000)$ & $(0.000)$ & $(0.000)$ \\
\hline
\end{tabular}


Table 3.8 continued

\begin{tabular}{|c|c|c|c|c|}
\hline & Model 1 & Model 2 & Model 3 & Model 4 \\
\hline \multirow[t]{2}{*}{ CG Proposal? } & 0.456 & 0.440 & 0.455 & 0.437 \\
\hline & $(0.118)$ & $(0.130)$ & $(0.119)$ & $(0.132)$ \\
\hline \multirow[t]{2}{*}{ CSR Proposal? } & $1.092 * * *$ & $1.079 * * *$ & $1.092 * * *$ & $1.075 * * *$ \\
\hline & $(0.000)$ & $(0.000)$ & $(0.000)$ & $(0.000)$ \\
\hline Firm Characteristics Controls & yes & yes & yes & yes \\
\hline Corporate Governance Controls & yes & yes & yes & yes \\
\hline Number of Observations & 7,903 & 7,903 & 7,903 & 7,903 \\
\hline Pseudo R-squared & 0.148 & 0.149 & 0.148 & 0.150 \\
\hline
\end{tabular}

In Models 3 and 4 of Table 3.8, I break down the aggregate institutional ownership measure into the three subcategories: transient, quasi-indexer, and dedicated institutions. The results of Model 3 show that the positive and significant effect of the institutional ownership on the withdrawal's likelihood in Model 1 is entirely driven by the stake held by the quasi-indexer institutions. This result is consistent with the results from my firmlevel analysis and points to the importance of the long-term, passively investing institutions as corporate monitors. In Model 4, I also control for the interaction effects between the ownership of each of the three classes of institutions and the institutional sponsorship. I find that the interaction between the ownership stake of the quasi-indexer institutions and the institutional sponsorship significantly increases the chances of a withdrawal. Furthermore, I also find a positive relation between the withdrawal's likelihood and the interaction between the institutional sponsorship and the ownership stake of the transient institutions. This finding implies that the ownership of the short-term oriented, institutional investors can also lead to a higher likelihood of withdrawal if the proposal sponsor is an institutional investor.

In all four models of Table 3.8, I control for the same firm, proposal, and sponsor characteristics. Concerning sponsor characteristics, I find that all of the sponsor control variables are positive and significant. These results hold for any of the four models in Table 3.8 and imply that the proposals filed by these shareholder groups are, on average, more likely to be withdrawn than the proposals filed by individual shareholders (the category of sponsors which is the base case in these regressions). My findings therefore support hypothesis H3.1. Furthermore, I also find that the CSR proposals are significantly more likely to be withdrawn than the CG proposals, which is consistent with my descriptive results discussed earlier in this chapter. I do not find a significant relation between the number of past withdrawn proposals and the current likelihood of withdrawal. This result is different from my results in the firm-level analysis in which I find a significant and positive relation between the past withdrawn proposals and the current withdrawal's likelihood.

Lastly, I find supportive evidence for research hypothesis H3.3. The CEO ownership reduces the likelihood that a proposal is withdrawn, even after controlling for the institu- 
tional ownership, the proposal's topic, and the sponsor. This is consistent with the firmlevel analysis and means that the corporate insiders are more likely to let the proposals go to a vote when they own a relatively large stake of their own corporation.

I continue with performing the same analysis for the two subsamples of shareholder proposals. Tables 3.9 and 3.10 replicate the models of the previous table for the two subsamples of the CG and the CSR proposals.

Compared to the firm-level analysis of the CG proposal withdrawals, Model 1 in Table 3.9 clearly shows that the effect of the institutional ownership on the withdrawal's likelihood disappears when I take the proposal-level approach. In Model 2, however, the interaction term between the institutional sponsor and the ownership remains positive and significant, which implies that the institutional ownership in combination with the institutional sponsorship still positively affects the withdrawal likelihood of the CG proposals. Models 3 and 4 of Table 3.9 again control for the subclasses of institutional investors. I find that the withdrawal likelihood of the CG proposals is positively affected by only the interaction between the institutional sponsorship and the ownership of the transient institutions.

In Model 2, I add a control variable for the interaction between the institutional sponsorship and the institutional ownership. The reason for the inclusion of this interaction term is that a proposal filed by an institutional investor with a corporation that is characterized by a relatively large institutional ownership share might be even more likely to be withdrawn because the sponsoring shareholder is supported by a large institutional shareholder base. Further, private talks among the different institutions might have gone on prior to the actual filing of the proposal. Hence, the managers might be aware of the multiplicative power of these proposals and are thus more likely to make concessions to the shareholders. My empirical results support this idea. The interaction term turns out significant and positive that means the withdrawal's likelihood increases when the institutional ownership is high and the proposal's sponsor is an institutional investor. Consequently, the addition of this control variable takes up all of the significant effect from the institutional ownership itself, which implies that the presence of an institutional sponsor is crucial to affect and to increase the withdrawal's likelihood.

In Model 2, I add a control variable for the interaction between the institutional sponsorship and the institutional ownership. The reason for the inclusion of this interaction term is that a proposal filed by an institutional investor with a corporation that is characterized by a relatively large institutional ownership share might be even more likely to be withdrawn because the sponsoring shareholder is supported by a large institutional shareholder base. Further, private talks among the different institutions might have gone on prior to the actual filing of the proposal. Hence, the managers might be aware of the multiplicative power of these proposals and are thus more likely to make concessions to the shareholders. My empirical results support this idea. The interaction term turns out significant and positive that means the withdrawal's likelihood increases when the institutional ownership is high and the proposal's sponsor is an institutional investor. Consequently, the addition of this control variable takes up all of the significant effect from the institutional ownership itself, which implies that the presence of an institutional sponsor is crucial to affect and to increase the withdrawal's likelihood. 
Table 3.9: Determinants of CG proposal withdrawal (proposal-level)

This table presents proposal-level logistic regressions where the dependent variable equals one if a corporate governance $(\mathrm{CG})$ proposal is withdrawn and zero otherwise. I only take into account filed CG proposals. All models control for the same firm characteristics as the models in Table 3.8 of this chapter. Further, I control for year and industry effects in all models, and all regression models also include a constant. All independent variables are winsorized at 1 and $99 \%$, respectively. The $* * *, * *$, and $*$ denote statistical significance at the $1 \%, 5 \%$, and $10 \%$ levels respectively. Robust p-values are in parentheses.

\begin{tabular}{lcc}
\hline & Model 1 & Model \\
\hline Institutional Ownership & 0.504 & 0.367 \\
& $(0.331)$ & $(0.484)$ \\
Institutional Sponsor * Institutional Ownership & & 1.336 \\
& & $(0.073)$
\end{tabular}

Ownership Dedicated Institutions

$0.490 \quad 1.142$

$(0.576) \quad(0.229)$

Ownership Quasi-Indexer Institutions

$0.820 \quad 0.656$

$(0.156) \quad(0.284)$

Ownership Transient Institutions

$-0.127 \quad-0.902$

$(0.875) \quad(0.308)$

Inst. Sponsor * Ownership Dedicated Institutions

Inst. Sponsor * Ownership Quasi-Index. Institutions

Inst. Sponsor * Ownership Transient Institutions

CEO Ownership

$-6.805^{* * *} \quad-6.701^{* * *} \quad-6.766^{* * *}$

\# Withdrawn Proposals T-1

$(0.000)$

$(0.000)$

$(0.000)$

$-6.746^{* * *}$

$-0.039$

$-0.040$

$(0.000)$

$(0.514)$

$(0.500)$

$-0.040$

HHI of Institutional Ownership

$\begin{array}{llll}4.264 & 10.623 & 1.705 & 8.870\end{array}$

(0.814)

$(0.927)$

$(0.640)$

Inst. Ownership * HHI Inst. Ownership

$-4.96$

$(0.572)$

$-2.966$

$-11.433$

Institutional Sponsor?

$(0.818)$

$-12.623$

$(0.889)$

$(0.604)$

$2.040^{* * *}$

$(0.571)$

$2.041 * *$

1.159 **

$(0.000)$

$(0.064)$

(0.000)

(0.050)

Coordinated Activist Sponsor?

$\begin{array}{llll}1.337 * * * & 1.338^{* * *} & 1.342 * * * & 1.342 * * * \\ (0.000) & (0.000) & (0.000) & (0.000) \\ 2.481^{* * *} & 2.493^{* * *} & 2.482^{* * *} & 2.497 * * * \\ (0.000) & (0.000) & (0.000) & (0.000)\end{array}$

Firm Characteristics Controls

Corporate Governance Controls

$\begin{array}{llll}\text { yes } & \text { yes } & \text { yes } & \text { yes } \\ \text { yes } & \text { yes } & \text { yes } & \text { yes }\end{array}$

Number of Observations

5,374

5,374

5,374

5,374

Pseudo R-squared

0.184

0.184

0.184

0.186 
I also find that for the CG proposals, the CEO ownership is the most important determinant of the proposal withdrawal. My proxy still exhibits a negative and very significant coefficient. The results in Model 4 concerning the CEO ownership indicate that a one standard deviation increase in the CEO ownership decreases the odds that a CG proposal gets withdrawn by $15.5 \%$. My results for the CG proposal withdrawals also show that the proposals submitted by institutional shareholders, labor unions, and coordinated activists are, on average, more likely to be withdrawn than the proposals of the individual investors that represent the base case in this analysis. Lastly, the likelihood that the CG proposals get withdrawn in the current year is not influenced by the number of withdrawn CG proposals over the last year.

The subsample of CSR proposals displays the following determinants of withdrawal. The results of the four models in Table 3.10 allude to the importance of the institutional ownership and the sponsor characteristics in the context of the withdrawal likelihood of the CSR proposals. I find that the institutional ownership on an aggregate level significantly increases the withdrawal likelihood of the CSR proposals (at the $10 \%$ level). Furthermore, the interaction between the institutional sponsorship and ownership in Model 2 is positive and significant at the $5 \%$ level, which implies that the CSR proposals are more likely to be withdrawn only if the institutional ownership is high and an institutional investor is the proposal sponsor.

The breakdown into the transient, quasi-indexer, and dedicated institutional investors (Models 3 and 4) shows that the ownership stake of the quasi-indexer institutions as well as the interaction between their ownership and the institutional sponsorship are significantly and positively related to the withdrawal likelihood of the CSR proposals. This result is important as I do not find a significant relation between the stake of the quasi-indexers and the withdrawal likelihood of the CSR proposals at the firm level. 
Table 3.10: Determinants of CSR proposal withdrawal (prop. level)

This table presents proposal-level logistic regressions where the dependent variable equals one if a corporate social responsibility (CSR) proposal is withdrawn and zero otherwise. I only take into account filed CSR proposals. All models control for the same firm characteristics as the models in Table 3.8 of this chapter. Further, I control for year and industry effects in all models, and all regression models also include a constant. All independent variables are winsorized at 1 and $99 \%$, respectively. The $* * *, * *$, and $*$ denote statistical significance at the $1 \%, 5 \%$, and $10 \%$ levels respectively. Robust p-values are in parentheses.

\begin{tabular}{|c|c|c|c|c|}
\hline & Model 1 & Model 2 & Model 3 & Model 4 \\
\hline \multirow[t]{2}{*}{ Institutional Ownership } & $1.087^{*}$ & 0.328 & & \\
\hline & $(0.095)$ & $(0.644)$ & & \\
\hline \multirow[t]{2}{*}{ Institutional Sponsor * Institutional Ownership } & & $1.646^{* *}$ & & \\
\hline & & $(0.016)$ & & \\
\hline \multirow[t]{2}{*}{ Ownership Dedicated Institutions } & & & 0.692 & 0.585 \\
\hline & & & $(0.504)$ & $(0.661)$ \\
\hline \multirow[t]{2}{*}{ Ownership Quasi-Indexer Institutions } & & & $1.740 * *$ & 0.555 \\
\hline & & & $(0.016)$ & $(0.530)$ \\
\hline \multirow[t]{2}{*}{ Ownership Transient Institutions } & & & 0.835 & 0.079 \\
\hline & & & $(0.405)$ & $(0.952)$ \\
\hline \multirow[t]{2}{*}{ Inst. Sponsor * Ownership Dedicated Institutions } & & & & 0.528 \\
\hline & & & & $(0.746)$ \\
\hline \multirow[t]{2}{*}{ Inst. Sponsor * Ownership Quasi-Indexer Institutions } & & & & $2.539^{* *}$ \\
\hline & & & & $(0.013)$ \\
\hline \multirow[t]{2}{*}{ Inst. Sponsor * Ownership Transient Institutions } & & & & 1.400 \\
\hline & & & & $(0.365)$ \\
\hline \multirow[t]{2}{*}{ CEO Ownership } & -0.737 & -0.522 & -0.571 & -0.315 \\
\hline & $(0.707)$ & $(0.787)$ & $(0.772)$ & $(0.872)$ \\
\hline \multirow[t]{2}{*}{ \# Withdrawn Proposals T-1 } & $0.151 * *$ & $0.151 * *$ & $0.152 * *$ & $0.153^{* *}$ \\
\hline & $(0.041)$ & $(0.040)$ & $(0.040)$ & $(0.038)$ \\
\hline \multirow[t]{2}{*}{ HHI of Institutional Ownership } & 4.559 & 11.094 & 13.457 & 18.305 \\
\hline & $(0.867)$ & $(0.683)$ & $(0.641)$ & $(0.524)$ \\
\hline \multirow[t]{2}{*}{ Inst. Ownership * HHI Inst. Ownership } & -1.315 & -8.483 & -11.694 & -17.299 \\
\hline & $(0.967)$ & $(0.787)$ & $(0.719)$ & $(0.595)$ \\
\hline \multirow[t]{2}{*}{ Institutional Sponsor? } & $2.459^{* * *}$ & $1.329 * *$ & $2.455^{* * *}$ & $1.083^{*}$ \\
\hline & $(0.000)$ & $(0.016)$ & $(0.000)$ & $(0.058)$ \\
\hline \multirow[t]{2}{*}{ Coordinated Activist Sponsor? } & $1.823 * * *$ & $1.865 * * *$ & $1.815^{* * *}$ & $1.866 * * *$ \\
\hline & $(0.000)$ & $(0.000)$ & $(0.000)$ & $(0.000)$ \\
\hline \multirow[t]{2}{*}{ Union Sponsor? } & $1.740 * * *$ & $1.803 * * *$ & $1.730^{* * *}$ & $1.803 * * *$ \\
\hline & $(0.000)$ & $(0.000)$ & $(0.000)$ & $(0.000)$ \\
\hline Firm Characteristics Controls & yes & yes & yes & yes \\
\hline Corporate Governance Controls & yes & yes & yes & yes \\
\hline Number of Observations & 2,375 & 2,375 & 2,375 & 2,375 \\
\hline Pseudo R-squared & 0.090 & 0.092 & 0.091 & 0.094 \\
\hline
\end{tabular}


Furthermore, the insider ownership does not affect the likelihood of a CSR proposal withdrawal as in the firm-level analysis; hence I do not find supportive evidence for H3.3 - at least for the subsample of the CSR proposals. In contrast to the CG proposals, I find a significant and positive relation between the number of the past year's withdrawn CSR proposals and the current year's withdrawal likelihood of the CSR proposals. This result implies that the filing and negotiating of the CSR proposals is indeed a continuous process that is likely to influence the future negotiations of the managers with the shareholders on CSR issues.

Again, in each of the four models, the sponsorship control variables consistently exhibit the same signs. The proposals of the institutional shareholders, labor unions and the coordinated activists are, on average, more likely to be withdrawn than the proposals filed by individual retail investors.

\subsection{The power of withdrawn shareholder proposals}

Thus far, I have looked at the major drivers behind the proposal withdrawals. I now turn to the question of how much the withdrawn shareholder proposals are actually a measure of successful shareholder engagement. Therefore, I first investigate in this section whether the withdrawn shareholder proposals are those proposals that also theoretically receive a very high voting outcome. Second, I look at the corporate changes caused by the voted and withdrawn shareholder proposals to evaluate my hypothesis that the withdrawn proposals are the strongest type of shareholder proposals.

For this kind of analysis, I rely on the shareholder proposals that deal with the compensation packages of the corporate executives because I can directly measure and quantify the changes in these packages after the proposal. I then undertake a propensity score matching approach based on my proposal-level analysis in Table 3.8. Essentially, I match every compensation proposal that is withdrawn with a compensation proposal that goes to a vote based on the firm characteristics, using the predicted withdrawal likelihoods of the analysis in Table 3.8. As one sees from Appendix 3.B, I have 487 withdrawn compensation proposals in my sample. Out of these, I am able to match 299 withdrawn compensation proposals with 299 corresponding voted compensation proposals.

In the first part of this indicative analysis, I investigate how the predicted withdrawal likelihoods correlate with the realized voting outcomes of the voted compensation proposals. In results not tabulated, I find that both are correlated at $20.6 \%$. This result is statistically significant at the $1 \%$ level. Hence, I conclude that the managers actually convince the shareholders to withdraw those proposals for which they indeed expect a high voting outcome in the first place. Consequently, the information content of the withdrawn proposals should not be underestimated. Many proposals that theoretically might get a high — and thus for the management adverse — voting result during the AGM are withdrawn beforehand after private negotiations between the managers and the sponsoring shareholder. 
To investigate the effects that the withdrawn shareholder proposals have on corporations compared to voted proposals, I undertake an analysis of the treatment (withdrawn compensation proposals) group and the control group (voted compensation proposals). In Table 3.11, I tabulate the results from a comparison of the different compensation package characteristics of the CEOs one year after the compensation proposal is withdrawn or voted on respectively. I compare the absolute dollar change in the total compensation, the absolute dollar change in the bonus payments, the percentage change in the bonus, as well as the percentage change in the salary level between the two groups. Panel A displays the analysis for the entire sample, irrespective of the voting outcomes of the voted shareholder proposals. I find that there are no significant differences in the changes of the different compensation characteristics between the voted and the withdrawn proposals. Specifically, Panel A indicates that the average change in total compensation and bonuses is negative for the withdrawn proposals, but this difference is not significantly different from the average change that I find for the voted compensation proposals. One explanation for this finding is the fact that I include the entire sample of voted compensation proposals in this analysis. This inclusion implies that I use those compensation proposals that display a very high voting outcome, but also those that have a very low voting outcome. If at all, the changes might be triggered by those voted proposals that get a higher voting result during the AGM, and not by the proposals that get few votes.

To account for this, I split the matched sample into matches that contain the voted compensation proposals that got fewer and more votes than the median matched compensation proposal. Panel B of Table 3.11 presents my findings for the subsample of matches with only the voted proposals that received below median voting outcomes. I find that CEO compensation packages change substantially after the withdrawn compensation proposals. The absolute change in total compensation and bonus payments as well as the percentage change in bonuses is negative for the withdrawn proposals. In contrast, I find that the average change is positive for the voted compensation proposals. I find that the changes in the total compensation, bonus payments, and the percentage change in salary are significantly different for the two groups when I test for the alternative hypothesis that the difference in changes in certain compensation characteristics is larger than zero (voted minus withdrawn). Hence, I conclude that the withdrawn compensation proposals generally reduce compensation levels for CEOs, while those compensation proposals that go to a vote and gather relatively few votes increase the compensation levels. The differences in the changes between the two groups are significant for a onesided t-test for three out of the four compensation package characteristics. 


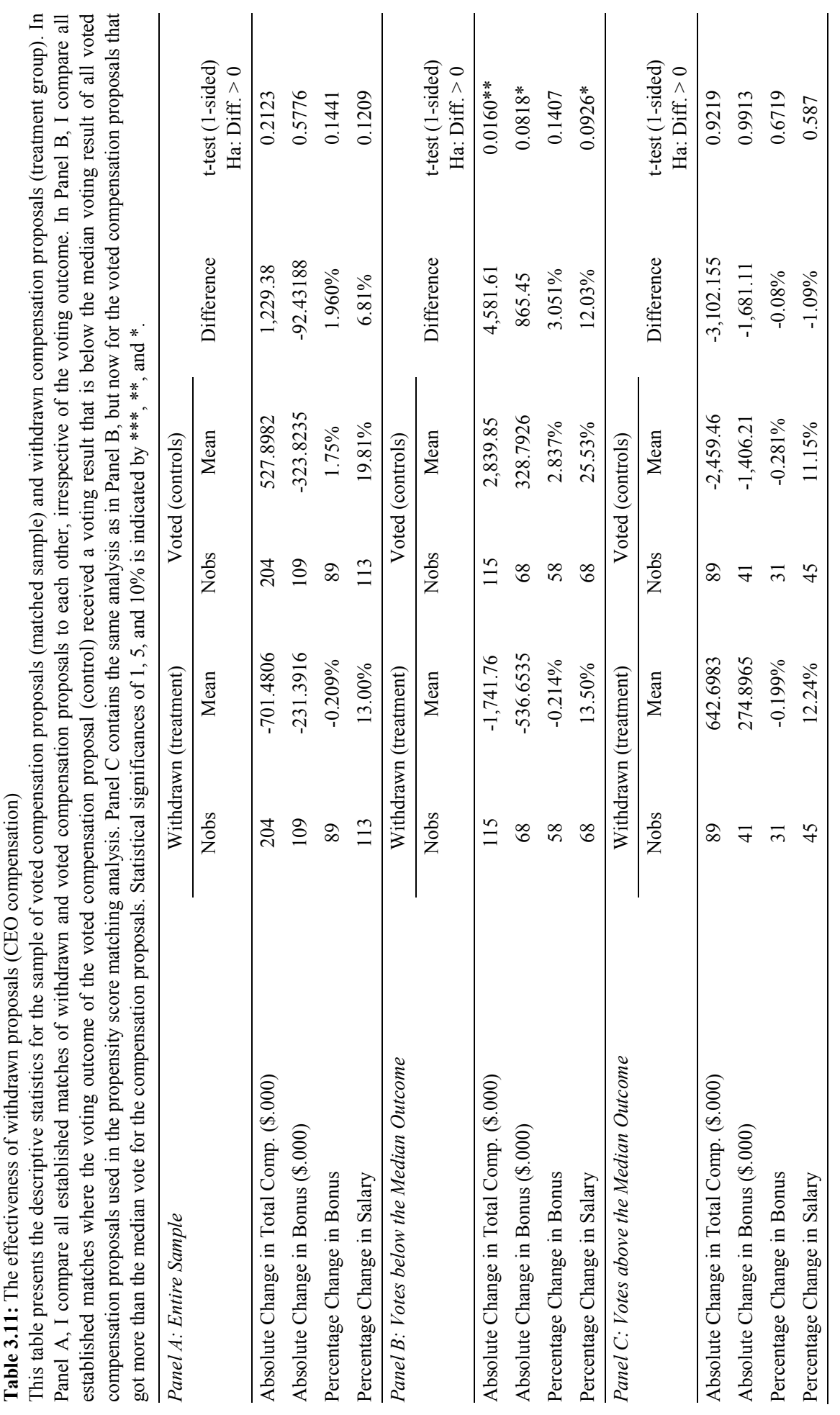


I repeat the exactly same analysis for those matches containing the voted compensation proposals that got more votes than the median compensation proposal. The results are displayed in Panel C of Table 3.11. On average, the withdrawn compensation proposals slightly increase the compensation levels (total and bonus payments). I also find a positive (negative) average percentage change in the salary levels (bonus levels). On the other hand, the average change for the voted compensation proposals is negative for three out of the four compensation package characteristics. Hence, the compensation proposals that manage to gather many votes during the AGM can have suppressing effects on the compensation levels. None of the differences is significantly larger than zero.

Overall, I conclude the following from the results presented in this section. By matching the voted and withdrawn compensation proposals based on the specific corporate and proposal characteristics as well as on the expected withdrawal likelihood, I first find that there is a significant correlation between the expected withdrawal likelihood and the realized voting outcomes of the matched proposals. Hence, managers withdraw those proposals for which they correctly anticipate a high voting outcome during the AGM. Further, when limiting the analysis to the compensation proposals that are less successful than the median compensation proposal, I show that the withdrawn compensation proposals have a suppressing effect on the compensation levels whereas the below median voted proposals have, on average, a positive effect on the compensation levels. Thus, I claim that most of the time the withdrawn proposals represent a corporate change.

\subsection{Concluding comments and discussion}

In the United States, shareholders frequently engage with corporations through the filing of proxy proposals. The shareholder proposals strive for changes in corporate behavior and performance. My results indicate that a lot of these filed shareholder proposals are withdrawn by the proposal sponsor because of successful private negotiations with the management before the AGM.

In this chapter, I study the determinants of the withdrawn shareholder proposals. Researching withdrawn shareholder proposals is important because the literature on voice engagement through the shareholder proposals generally lacks evidence on the withdrawn proposals. There are only two studies that explicitly study private negotiations and proposal withdrawals, namely Chidambaran and Woidtke (1999), and Carleton, Nelson, and Weisbach (1998).

I hypothesize that the withdrawal's likelihood is a function of the sponsor's identity, the proposal's content, and the target corporation's ownership structure. I claim that the proposals filed by more influential shareholders (i.e., institutional investors or labor unions) are more likely to be withdrawn than the proposals handed in by the private shareholders. Furthermore, I conjecture that the withdrawal's likelihood increases with the institutional ownership because the managers are more likely to make advances to 
the sponsoring shareholder when a large institutional shareholder base is present. Lastly, I presume that the insider holdings negatively affect the withdrawal's likelihood.

My results can be summarized as follows: I find that the level of filed and withdrawn proposals is higher during the second half of the sample period. The shareholders are frequently invited into private negotiations as represented by the large number of withdrawn proposals during the latter years of the sample period. Moreover, I find that the CSR proposals are more often withdrawn than the CG proposals. In my eyes, these descriptive results already show the importance of the filed and withdrawn proposals as a corporate governance device available to shareholders.

My multivariate results disclose the following: First, the proposals filed by the labor unions and the institutional shareholders are more likely to be withdrawn than proposals filed by private, individual investors. These results hold for both the firm-level and proposal-level analyses and are consistent with my empirical predictions that the proposals filed by more influential shareholders are more likely to be withdrawn. Second, I find that the withdrawal's likelihood is a function of the institutional and the insider ownerships. My firm-level results for the entire sample of proposals indicate that the withdrawal's likelihood increases with the institutional ownership, and decreases with the insider ownership. This result also holds for the subsample of CG proposals. I also find that the positive relation between the withdrawal's likelihood and the institutional ownership is driven by long-term oriented, passively investing institutions, that is, quasiindexer institutions.

My proposal-level multivariate results for the entire sample and the subsample of CG proposals shows that the positive effect of institutional ownership on the withdrawal's likelihood is most pronounced if the proposal sponsor is an institutional investor. It is furthermore important to point out that my results show that the insider ownership is not significantly related to the withdrawal likelihood of the CSR proposals, neither at the firm-level nor at the proposal-level analyses.

The implications of my third chapter are manifold for the investment community, corporate managers, and academics. I document that the entire proxy proposal process is an important corporate governance mechanism. It is not just the voting process during the AGM itself that matters; it is the entire negotiation process preceding the AGM. Withdrawn proposals are the outcome of this private negotiation process. I observe a high number of proposal withdrawals every proxy season. This means, and my results support this claim, that managers care about specific proposals and that they want to prevent specific proposals from going to a vote during the AGM.

My results are of value to managers and shareholders. Managers, on the one hand, can take my results into account when they are faced with a shareholder proposal. Should they enter into negotiations with the shareholders or let the proposal go to a vote? How likely is it that the sponsoring shareholder is going to withdraw the proposal? Given my results, managers can take into account the information on the firm's ownership structure, the proposal's content, and the sponsor's identity to answer these and related questions. Shareholders, on the other hand, can consider my results as well. My findings give an indication of which corporation might be more responsive to the shareholders. Hence, the shareholders could anticipate before the actual filing of the proposal how 
likely it is that they might get invited into private negotiations by the management of the target corporation.

I provide some new evidence on the entire proxy proposal process. I shed light on the private negotiations that take place after a shareholder has filed a proposal. What is left for the future research are the real private negotiations that take place behind the scenes before any public filing of a proposal occurs. Studying these could show how shareholders, in particular institutional investors, continuously interact with corporations. Only by also investigating this kind of engagement can one conclude how successful the engagement activities of shareholders are. Such an analysis of the private engagements is undertaken in the following chapter of my dissertation. 
WITHDRAWN SHAREHOLDER PROPOSALS

\section{Appendix 3.A: Proposal topics and sponsor categories}

\begin{tabular}{ll}
\hline Proposal Topics (Content) & Topic Examples \\
\hline Corporate Governance & \\
Compensation & $\begin{array}{l}\text { Award performance-based stock options, award golden para- } \\
\text { chutes, link pay to performance, approve executive compensation, } \\
\text { restrict compensation }\end{array}$ \\
& Redeem or vote on poison pill, eliminate supermajority provision, \\
& vote on takeover provisions, restore right to call a special meeting \\
External Governance & Separate chairman/CEO, introduce confidential voting, repeal \\
classified board, limit director tenure, introduce confidential & voting \\
Internal Governance & Sell the corporation, reject merger, spin off division, spin off \\
& tobacco business \\
Takeover & Label gene-engineered food, adopt sexual orientation anti-bias \\
Corporate Social Responsibility & policy, implement ILO standards and third-party monitoring, \\
issue sustainability report, adopt code of conduct for China opera- & tions \\
Endorse Ceres principles, report on global climate change, report \\
on supplier environmental standards, reduce radioactive emis- \\
sions, develop renewable energy alternatives
\end{tabular}




\section{Appendix 3.B: All filed and withdrawn shareholder proposals}

This table presents the number of filed shareholder proposals split up into the different proposal topics. Note that I include all of the shareholder proposals for which the information on the proposal topic is available. The second column presents the number of all of the filed shareholder proposals for each topic. In the third column, I list the total number of the withdrawn proposals for each category. The last column includes the percentage fraction of the proposals that are withdrawn for each proposal topic.

\begin{tabular}{lccc}
\hline Panel A: Crude Classification & & & \\
Topic & \# Filed & \# Withdrawn & Withdrawn \% \\
\hline Corporate Governance & 8,664 & 1,454 & $16.8 \%$ \\
Corporate Social Responsibility & 3,530 & 1,103 & $31.2 \%$ \\
Other & 280 & 28 & $10.0 \%$ \\
Total & 12,474 & 2,585 & $20.7 \%$ \\
\hline & & & \\
\hline Panel B: Detailed Classification & & & \\
Topic & $\#$ Filed & \# Withdrawn & Withdrawn \% \\
\hline Corporate Governance & 8,664 & 1,454 & $16.8 \%$ \\
Compensation & 2,637 & 487 & $18.5 \%$ \\
Amend Compensation & 535 & 116 & $21.7 \%$ \\
Approve Compensation & 782 & 138 & $17.6 \%$ \\
Compensation Committee & 31 & 10 & $32.3 \%$ \\
Disclosure and Reporting Proposals & 301 & 58 & $19.3 \%$ \\
Increase Compensation & 243 & 60 & $24.7 \%$ \\
Restrict Compensation & 685 & 82 & $12.0 \%$ \\
Miscellaneous & 60 & 23 & $38.3 \%$ \\
External & 1,093 & 110 & $10.1 \%$ \\
Other External & 236 & 16 & $6.8 \%$ \\
Poison Pill & 591 & 58 & $9.8 \%$ \\
Reincorporation & 50 & 11 & $22.0 \%$ \\
Supermajority Provision & 216 & 25 & $11.6 \%$ \\
Internal & 4,602 & 831 & $18.1 \%$ \\
Board & 1,884 & 228 & $12.1 \%$ \\
Voting & 1,112 & 266 & $23.9 \%$ \\
Other Internal & 1,606 & $26 \%$ \\
Takeover & 332 & & $7.8 \%$ \\
\hline & &
\end{tabular}


WITHDRAWN SHAREHOLDER PROPOSALS

\begin{tabular}{lccc}
\hline Panel B: Detailed Classification & & & \\
Topic & \# Filed & \# Withdrawn & Withdrawn \% \\
\hline Corporate Social Responsibility & 3,530 & 1,103 & $31.2 \%$ \\
Environmental & 872 & 257 & $29.5 \%$ \\
Animal & 150 & 28 & $18.7 \%$ \\
Ceres & 128 & 63 & $49.2 \%$ \\
Arctic Drilling & 18 & 2 & $11.1 \%$ \\
Forest & 12 & 3 & $25.0 \%$ \\
Other Environmental & 107 & 28 & $26.2 \%$ \\
Pollution & 72 & 12 & $16.7 \%$ \\
Nuclear Power & 52 & 0 & $0.0 \%$ \\
Climate Change & 333 & 121 & $36.3 \%$ \\
Social & 2,658 & 846 & $31.8 \%$ \\
Health & 419 & 133 & $31.7 \%$ \\
Other Social & 959 & 262 & $27.3 \%$ \\
Country Specific & 109 & 18 & $16.5 \%$ \\
Human Rights & 103 & 17 & $16.5 \%$ \\
Labor Standards & 252 & 67 & $26.6 \%$ \\
Non-Discrimination & 538 & 241 & $44.8 \%$ \\
Tobacco & 116 & 26 & $22.4 \%$ \\
Diversity & 162 & 82 & $50.6 \%$ \\
Other & 280 & 28 & $10.0 \%$ \\
Total (all proposals) & 12,474 & 2,585 & $20.7 \%$ \\
\hline
\end{tabular}





\section{CHAPTER 4 The Geography of Shareholder Engagement: Evidence from a Large British Institutional Investor $^{10}$}

In this chapter, I study the global shareholder engagement activities of a large UK-based asset manager from 2006 to 2011. Using proprietary data on these activities, I find that "behind the scenes" shareholder engagements are frequently used to change corporate behavior. I show that geography is an important determinant for the occurrence of such engagements: UK corporations receive significantly more engagements than their foreign counterparts. This finding gives rise to a "home bias" in shareholder engagement. I also find that the extent of the successful shareholder engagements is significantly higher for US corporations than for domestic UK corporations.

\footnotetext{
${ }^{10}$ This chapter is based on Bauer, Clark, and Viehs (2013). I thank seminar participants at Maastricht University, and I acknowledge the data and support provided by a large UK institutional investor. Frank Moers deserves special gratitude as his comments considerably improved this chapter. I am also grateful to Valentin Peter for excellent research assistance. Major parts of this chapter were completed while I attended the Oxford University School of Geography and the Environment as a visiting scholar.
} 
CHAPTER 4 


\subsection{Introduction}

Institutional investors frequently use engagement tactics to influence and change the corporations they are invested in. In particular, many institutions strive for changes in the corporate environmental, social and governance (ESG) policies to ensure the sustainability of investee corporations. Often, these institutional investors engage with the investee corporations on a private basis through management meetings or email correspondence to achieve their goals. In this chapter, I study the shareholder engagement activities of one institutional investor, namely a large UK-based asset manager.

This conventional asset manager offers engagement services to institutional clients. The engagement services comprise active voting at AGMs and direct engagement with investee corporations through management meetings, telephone calls, emails, letters, and corporate visits with the aim of changing the ESG policies. ${ }^{11}$ Hence, I also call this asset manager an "engagement agent." As of September 2012, the engagement agent was hired by 25 institutional investors with diversified investment portfolios whose combined assets under management were equal to US\$ 82.8 billion.

Every year since 2006, the engagement agent, together with its institutional clients, sets up a so-called "priority list" of corporations. For these corporations, both the engagement agent and the institutional clients view immediate engagement action regarding ESG policies as necessary. Hence, I analyze all of the engagement agent's activities in 397 unique "priority" corporations located in 37 different countries from 2006-2011.

By studying this proprietary engagement data set, I aim to show the key determinants of the global engagement activities and their success. Although I am only providing a snapshot of a single European asset manager, I am able to give the answers to three important research questions. Which corporations does the institutional investor engage with and how does geography drive the intensity of such engagements? Second, are the factors that drive these private engagements similar to those in the public engagement literature, for example, shareholder proposals? And third, does geography drive the success of these engagement activities?

The recent literature on corporate governance (CG) illustrates the growing importance of the shareholder engagement by institutional investors (e.g., McCahery, Sautner, and Starks, 2013). The underlying engagement data of my engagement agent has also been used in two other studies on shareholder engagement in slightly modified versions. First, Dimson, Karakas, and Li (2013) study the shareholder engagement activities at 613 US corporations from 1999-2009 and find an annual abnormal stock price reaction of $4.4 \%$ for the corporations where the institutional investor successfully achieved change. These authors provide the first evidence that the shareholder engagement activi-

\footnotetext{
11 Throughout this chapter, I do use the term shareholder engagement to describe all actions undertaken by shareholder to change corporate behavior. I distinguish between private and public shareholder engagement: Private shareholder engagements are private dialogues and direct interventions from shareholders at investee corporations and they are not observable. Public shareholder engagements are, for example, shareholder proposals, which are observable by others.
} 
ties of the institutional investor are value-enhancing. Second, the fifth chapter of my dissertation analyzes all 1,894 US corporations that are in the investment portfolio of the engagement agent and its institutional clients. There, I investigates the shareholder engagement activities of the engagement agent in the context of shareholder proposals to show whether the corporations are more or less likely to honor the engagements when several different forms of engagement are simultaneously present. I find that the corporations are significantly more likely to honor the engagements of any kind as soon as they receive both types of engagement (shareholder proposals from any shareholder and corporate engagements from the engagement agent) simultaneously.

The sample of corporations that I investigate in this chapter is smaller than the underlying samples of Dimson, Karakas, and Li (2013) and Chapter 5 because I exclusively focus on a global sample of engaged priority corporations between 2006 and 2011. This focus implies that I use those corporations for which the engagement agent and its institutional clients classify the engagement's necessity as the highest. I start by presenting an overview of the global engagement activities that shows in which countries the priority corporations domicile and also shows the evolution of the shareholder engagements during the sample period from 2006-2011. I then continue with an empirical investigation of the determinants of the intensity of the engagements. In particular, I study the effect of the geographical factors on the intensity of the engagements that a priority corporation experiences. In this analysis, I do not only look at the geographical location of the priority corporations, but I also investigate whether the legal regime of incorporation influences the engagement intensity. The empirical finance literature shows that geographic factors (e.g., Chhaochharia, Kumar, and Niessen-Ruenzi, 2012) as well as legal regimes have a substantial effect on the governance structures of corporations as well as on their financing policies (see, e.g., La Porta, Lopez-de-Silanes, and Shleifer, 1999; La Porta, Lopez-de-Silanes, Shleifer, and Vishny, 2000a, 2000b). My analysis adds to this literature by revealing whether geography also matters to the global shareholder engagements of the engagement agent. Lastly, I examine the determinants of the engagement success. Specifically, I study the effect of geography on the engagement success along with several other target firm characteristics, as in the spirit of Dimson, Karakas, and Li (2013).

My findings can be summarized as follows: I find that the engagement agent very actively engages with priority corporations over the investigated time period. Overall, I document that the agent raises 6,837 objectives in 397 unique priority corporations from 37 countries. Furthermore, the data reveal that the engagements entail 592 instances in which the investee corporations changed their behavior according to the requests of the agent, which represent successful engagements (also called milestones). Approximately $40 \%$ of all of the stated objectives deal with corporate governance issues, followed by social and environmental issues (28 and 32\%, respectively). I further detect a clustering of corporations in the Anglo-Saxon countries: Out of the 397 priority corporations, 84 
domicile in the United Kingdom, and 75 domicile in the United States. ${ }^{12}$ Throughout this chapter, I use the term objectives for the engagement activities of the engagement agent. The empirical results of my chapter allude to a home bias in the agent's engagement decision: the corporations from the United Kingdom get significantly more objectives than their foreign counterparts. I argue that the proximity to the target corporations and better knowledge of the regulatory environment in the home market drive my results because information asymmetries are relatively lower for the proximate corporations. In addition, I find that the larger corporations get relatively more objectives than their smaller counterparts. Importantly, I also find a positive relation between the number of the past engagements and the number of the current engagements. Hence, my results indicate that the engagement intensity is driven by the established relationship between the engagement agent and its investee corporations. A closer collaboration on particular issues raises the number of the objectives that a particular corporation receives in the future. Consistent with the literature on public shareholder engagement tools, I find that the poorly performing corporations are more frequently targeted with private engagements.

Regarding the determinants of the successful engagements, I find that, on average, relative to the corporations originating in the United Kingdom, the corporations in the United States and Continental Europe have significantly more successful engagements. This finding, even though counterintuitive at first sight, is consistent with my previous findings on a home bias in the engagement intensity. The engagement agent targets and selects more carefully those corporations abroad for which the expected success likelihood is most likely the highest. Additionally, when I limit the analyses to only successful social engagements, I find that the corporations in Japan and the United Kingdom display significantly more successes than the corporations originating in all of the other countries.

Shareholder engagement is not a new phenomenon. The literature focuses on shareholder proposals (e.g., Gillan and Starks, 2000) ${ }^{13}$, class-action lawsuits (e.g., Romano, 1991) ${ }^{14}$, and the Wall Street Walk (e.g., Edmans, 2009; Admati and Pfleiderer, 2009) as the most important engagement tools available to shareholders. Further, the literature also finds that institutional investors are important corporate monitors because they have more power and incentives to monitor the corporation and also to promote changes due to their large stakes in the corporation (Burkart, Gromb, and Panunzi, 1997; Shleifer and Vishny, 1986). The evidence also suggests that particular groups of the institutional

\footnotetext{
${ }^{12}$ Note that the 75 priority US corporations are most likely also part of the sample of corporations used in Dimson, Karakas, and Li (2013). However, the difference between the 613 US corporations used in their analysis and the 75 US corporations in my sample (= 538 corporations) is due to the fact that none of their additional 538 corporations ever appear on the priority list between 2006 and 2011.

${ }^{13}$ Other interesting studies on shareholder proposals are Karpoff, Malatesta, and Walkling (1996); Gillan and Starks (2007); Ferri and Sandino (2009); Buchanan, Netter, Poulsen, and Yang, 2012; Ertimur, Ferri, and Stubben (2010); Ertimur, Ferri, and Muslu (2011); Bauer, Braun, and Viehs (2012); Bauer, Moers, and Viehs (2013).

${ }^{14}$ Other exemplary studies include Bauer and Braun (2010) and Gande and Lewis (2009).
} 
investors can promote change at corporations and positive shareholder value effects. The literature mentions pension funds (Del Guercio and Hawkins, 1999) and hedge funds (Klein and Zur, 2009) as important institutional activist investors. ${ }^{15}$

Another paper discussing shareholder engagement by institutional investors is McCahery, Sautner, and Starks (2013). Using survey evidence, they find that the institutional investors use several engagement tactics to change the corporations with respect to their ESG structures. Among the most often adopted engagement tools are the private dialogues and the direct management meetings (McCahery, Sautner and Starks, 2013), which are the means of engagement that I investigate in this chapter.

The literature on private engagements by institutional investors is relatively scarce. I argue in Chapter 3 that these private engagements might be an even more powerful way of engaging the corporations in the United States than public engagements, like shareholder proposals. The reason for this argument is that I find that about $20 \%$ of all of the shareholder proposals are withdrawn by the lead sponsoring shareholder after the private negotiations with the management of the target corporation. Carleton, Nelson, and Weisbach (1998) provide similar arguments after investigating the successes of the TIAA-CREF's private negotiations with its investee corporations. Likewise, Becht, Franks, Mayer, and Rossi (2009) study the private engagement activities of the Hermes UK Focus Fund and conclude that its engagement activities create shareholder value, which also translates into the superior performance of the entire fund. As mentioned before, in a study which is closely related to mine, Dimson, Karakas, and Li (2013) use similar engagement information from the same engagement service provider as I do in this chapter. By analyzing a U.S. sample of corporations they conclude that successful engagements translate into a $4.4 \%$ annual abnormal return. Given this evidence, corporate engagements by institutional investors can benefit shareholders.

I contribute to this stream of literature on shareholder engagement along two main lines. First of all, I am the first to study the global engagement activities of one particular institutional investor. The literature on shareholder engagement mainly focuses on Anglo-Saxon countries, for example, the United States and the United Kingdom. To the best of my knowledge, there is no evidence on shareholder engagement at the international level. My data set allows me to study whether the geographic factors also influence an institutional shareholder's decision to engage with a corporation. Second, another significant contribution of my chapter is that I investigate all of the engagement activities in all three of the ESG dimensions of this engaging institution. The literature on (public) shareholder engagement focuses on the corporate governance engagements most of the time. Hence, my results provide additional evidence on the question of whether the shareholder engagement on corporate governance issues is driven by the same determinants as the engagements on the social and environmental issues.

\footnotetext{
15 There is a plethora of literature on shareholder engagement from pension funds and hedge funds. Smith (1996) and Wahal (1996) are seminal examples of pension fund engagement in the United States. Further, Brav, Jiang, Partnoy, and Thomas (2008) as well as Brav, Jiang, and Kim (2012) and Klein and Zur (2009) are further famous examples on hedge fund engagement.
} 
The remainder of this chapter is organized as follows. In Section 4.2, I present the theoretical background for the chapter and the corresponding hypotheses I test. In Section 4.3, I present my data set and the empirical methods used. In Section 4.4, I show my empirical results. Section 4.5 summarizes the chapter and provides concluding remarks.

\subsection{Theoretical considerations and hypotheses development}

I study the engagement activities of one large UK-based asset manager that provides engagement services to institutional clients as an engagement agent. This agent engages investee corporations on behalf of institutional clients and for its own investment portfolio. The institutional clients originate mainly from Europe and generally hold large, diversified investment portfolios. However, the relevant portfolio corporations in which the agent and its clients are invested in are spread around the world. A significant portion of the clients' as well as the agent's portfolio corporations are located in jurisdictions other than the Anglo-Saxon market. Therefore, these corporations are exposed to different government regulations with respect to ESG matters. The difference in regulations raises many questions as regards to which corporations are being targeted with which kinds of ESG issues and which standards and expectations are applied concerning the investee corporations' adopted ESG standards.

The fact that geography and proximity matter in the context of corporate finance, corporate governance, and investments is well-established in the literature. ${ }^{16}$ The research finds that retail and institutional investors tend to invest in the corporations that are familiar to them (Huberman, 2001). The investment literature also shows that institutional investors tend to invest in the stocks and the corporations that are in close proximity to them (Coval and Moskowitz, 1999). Further, the literature shows that these local, or home, investments also provide the investors with significant abnormal returns (Coval and Moskowitz, 2001). In addition, both Ivkovic and Weisbenner (2005) and Bodnaruk (2009) find that households are quite prone to investing in local stocks. My chapter is related to this stream of literature in the sense that I am investigating whether such a home bias also exists for shareholder engagements by institutional investors. This is an important question to all investors who want to engage with the corporations through an engagement agent that is situated in a particular geographical region.

More recently, the literature provides evidence that the proximity affects the governance role of the institutional investors. For example, Baik, Kang and Kim (2010) study local institutional investors and test whether they have informational advantages over the non-local institutional investors. The authors' results confirm this claim because they find that the local institutional ownership is positively related to the performance of future stock prices. Likewise, Chhaochharia, Kumar, and Niessen-Ruenzi (2012) find that the corporations with more local institutional ownership are on average more profit-

\footnotetext{
${ }^{16}$ There is also literature on the effects of the proximity of the banks to their lenders that I leave out of the discussion for brevity. See, for example, Petersen and Rajan (2002) as well as Mian (2006).
} 
able and have better quality governance than their counterparts with non-local ownership. Furthermore, the authors also find that the local institutions tend to file more shareholder proposals than the non-local institutions (Chhaochharia, Kumar, and NiessenRuenzi, 2012). Hence, the local institutional investors are presumably more effective in monitoring the corporate actions and policies because their close proximity helps them to overcome information asymmetries. Thus, local institutional investors exploit their informational advantage and become effective corporate monitors.

This entire stream of literature amplifies the fact that the geographic location of the corporations and the actual distance to their important shareholders matters in the context of corporate finance and governance. Hence, I claim that geography is also a major -if not the most important-determinant of the intensity of the shareholder engagement by this particular engagement agent. Therefore, my first research hypothesis is the following:

H4.1: The corporations from more distant markets (e.g., Japan and United States) receive significantly fewer objectives relative to the corporations domiciling in the United Kingdom.

The accounting and investment literature emphasizes that the portfolios of large pension funds, insurance companies, and asset managers often hold many different corporate stocks in diversified portfolios that sometimes mimic a particular stock market index (e.g., Bushee, 1998). Consequently, these institutional investors often hold the biggest corporations from the different capital markets. These corporations are the most liquid and also the most visible corporations. The evidence on institutional investing suggests that the corporations with greater visibility have more institutional investors as shareholders (e.g., Grullon, Kanatas, and Weston, 2004). Furthermore, the research shows that when corporations hire investor relation firms to enhance their visibility, they can attract institutional investors, even to smaller corporations (Bushee and Miller, 2012). The fact that institutional investors tend to invest more in the stocks of large corporations implies that the intensity of their engagements also increases for these corporations.

H4.2: The larger corporations receive significantly more objectives than their smaller counterparts.

Regarding the determinants of successful engagements I argue in the following way. I conjecture that the success of engagement activities is mainly driven by geography. A UK-based institutional investor might not have the knowledge about corporations in very remotely located regions or countries and also not about the national standards regarding certain corporate policies. These facts could make the shareholder engagement less effective. Hence, higher information asymmetries between remotely located corporations and foreign institutional investors make their shareholder engagement less likely to be successful. 
H4.3: Corporations from more distant markets (e.g., Japan and United States) display significantly lower milestones-per-objectives ratios relative to the corporations domiciling in the United Kingdom.

I test these research hypotheses in the empirical part of this chapter in order to draw conclusions about the role of geography in the context of the engagement activities of an UK-based institutional investor.

\subsection{Sample description and methods}

In this section, I present the four components of my analyses. First, I introduce the engagement agent. I then continue in a second step with a description of the details of the engagement data. Third, I present my data sources for firm characteristics and the information on geography. Fourth, I outline the methods used to test my research hypotheses.

\subsubsection{The engagement agent and the priority list of corporations}

The main data source for this chapter is the proprietary engagement data from the UKbased engagement agent. The agent is a conventional asset manager that is also active in shareholder engagement. The assets of its total client base represent US\$154 billion. The main activities of this engagement agent comprise the management of its clients' funds as well as engaging with investee corporations on behalf of its 25 engagement clients that represent a combined asset base of US $\$ 82.8$ billion. In particular, the engagement agent engages in ESG areas of the investee corporations.

Every year since 2006, this engagement agent sets up a priority list of corporations for which engagement in ESG areas is of the highest importance to both the agent and its corresponding engagement clients. The clients generally communicate upfront on which portfolio corporations they have specific ESG concerns for. The actual decision about specific engagements at particular corporations is then solely at the discretion of the engagement agent. That is, the ultimate engagement decision is undertaken by the responsible investment and engagement team of the asset manager.

I base my sample on all of the priority corporations that appeared on the list between 2006 and the first quarter of 2011. Over this time period, I identify 397 unique corporations from 37 different countries. For all of the 397 priority corporations in my sample, I collect information on all of their engagement activities between 2006 and 2011. As the construction of the priority list is a continuous process, the composition of the list changes yearly. That is, some corporations drop out, new corporations are included, and some corporations remain on the list for several years. Sometimes, the corporations that drop out are subsequently added back. Hence, the number of corporations varies over time. I include every corporation that is on a priority list in a given year in my sample, leading to 993 firm-year observations.

As part of the engagement agent's process, there is also a continuous yearly backreporting to the client base. Every year, the clients of the engagement product receive a 
detailed report on all of the engagements undertaken along with their milestones. Because these reports are in part based on the same engagement information that I use in this chapter, I can verify that the information on the priority corporations is trustworthy. Dimson, Karakas, and Li (2013) make a similar point concerning the reliability of the data from the same asset manager.

\subsubsection{The engagement data}

Given the proprietary engagement data for all of the priority corporations from 20062011, I manually construct my data set. After reading all of the communication material, I first code the data in such a way that I am able to set up the panel of priority corporations. The engagement information for my sample of corporations is very detailed. For every corporation, I receive the full record of communication material over the time period from 1999-Q1/2011. These records comprise detailed information and descriptions of the nature of the engagements, the topics and objectives that were discussed with a particular investee corporation, and records about the successful engagement activities. This information comes from all of the telephone calls, emails, letters, and management meetings and the like.

For every engagement activity, the engagement agent indicates which topics were addressed and discussed with the target corporations. For example, if the engagement agent discusses the compensation structure of corporation $X$ with the management team and explicitly asks for a change in the compensation policies, the engagement agent specifies in its engagement data that during this particular management meeting the issue of corporate governance, and in particular, executive compensation was discussed. In the following, the issues that the institutional investor has discussed with investee corporations are also called objectives. ${ }^{17}$

The objectives that the engagement agent raises at investee corporations can fall into nine different categories: (1) corporate governance, (2) sustainability management and reporting, (3) business ethics, (4) human rights, (5) labor standards, (6) public health, (7) environmental management, (8) ecosystem services, and (9) climate change. A full list of the topics are in Appendix 4.A of this chapter ${ }^{18}$. The engagement agent's internal reporting system has changed over time. This evolution means that the aforementioned nine categories are only valid after 2005. Before 2005, the agent classified the themes into governance (old), environment (old), social (old), and sector specific (as displayed in the lower right part of Appendix 4.A). In case that I still identified old classifications and to avoid erroneous classifications of the objectives, I subsume all of the old themes and all of the corresponding new themes into my newly constructed and consistent objective classifications: governance (new), environment (new), social (new), and sector

\footnotetext{
${ }^{17}$ In the remainder of this chapter I use the terms objectives and issues interchangeably.

${ }^{18}$ Every topic has also subcategories, which make an even more detailed classification of engagement activities possible. A full list of all possible objectives topics and corresponding sub-categories is given in Appendix 4.A of this chapter.
} 
specific (new). Governance (new) consists of (1) corporate governance, (2) sustainability management and reporting, and governance (old). The social (new) category consists of (3) business ethics, (4) human rights, (5) labor standards, (6) public health, and social (old). The new environment category consists of (7) environmental management, (8) ecosystem services, (9) climate change, and environment (old). These new classifications make separate investigations of $\mathrm{E}, \mathrm{S}$, and $\mathrm{G}$ engagement types possible, which has not been done before in the literature.

Next to the information on the objectives discussed with a corporation, the engagement agent also provides information on the success of its engagements. More specifically, the agent records so-called Milestones when a specific engagement activity in a particular topical area leads to a change at an investee corporation. These milestones are directly linked to the topics of the objectives and thus allow me to link the objectives to the agent's corresponding engagement successes. Here, I follow Dimson, Karakas, and $\mathrm{Li}$ (2013) and assume that this information on successful engagements is reliable and trustworthy because it is the same information that the engagement agent supplies its clients.

Then, I calculate the yearly number of objectives raised in each of the aforementioned subject areas as well as the corresponding number of milestones for every sample corporation. I read all of the engagement information for every corporation separately and manually and then compile it into one panel of corporations. Overall, several corporations appear multiple times leading to a full data set of 993 firm-year observations with a total of 6,837 objectives and 592 milestones.

\subsubsection{Firm-level characteristics and geographic information}

To answer my main research questions, I need to control for firm characteristics and geographic variables that influence either the engagement actions by the shareholders or the corporate financing decisions in general.

Regarding the geographical background of the corporations, I assign one of the five following geographical regions or countries to each of my sample corporations by means of indicator variables: United States, Continental Europe, United Kingdom, Japan, and All other countries. I retrieve the information on the country of origin from Thomson Reuters' Worldscope.

All of the remaining firm-level information also comes from Worldscope. I control for various firm characteristics that play a role in corporate governance and/or shareholder engagements according to the literature. I am especially interested in the investee corporation's size, leverage, valuation, financial performance, and ownership structure. These factors are important determinants of the engagement decisions of institutional investors, especially hedge funds (e.g., Klein and Zur, 2009; Brav, Jiang, Partnoy, and Thomas, 2008).

My measure for the firm size is the natural logarithm of the (Total assets). I believe that firm size is also an appropriate measure for visibility because the largest corporations are also included in the country's major stock market indices and thus are more 
visible to foreign institutional investors. The literature documents empirically that institutional investors prefer to invest in larger corporations in an international context (e.g., Ferreira and Matos, 2008).

Further, I construct a measure for an investee corporation's Leverage by scaling the total debt by the total assets. I also control for whether the sample corporations are paying dividends by adding an indicator variable that equals one if the corporation pays out dividends to common shareholders and zero otherwise (Dividend payer?). Next to these variables, I also use a performance variable, one-year sales growth (1yr sales growth), to investigate the effect of the past performance on the engagement agent's decision to engage with the portfolio corporations. The literature shows that the past performance significantly influences the likelihood that the corporations will receive shareholder proposals (e.g., Chapter 2).

To control for the ownership structure of the corporations, I use the percentage of closely held shares of the corporate insiders, other corporations, and pension funds (Closely held shares (\%)) ${ }^{19}$ because the literature finds that the ownership of corporate insiders and also institutional investors is an important determinant of successful private negotiations (see Chapter 3). Lastly, the valuation measure for the sample corporations is Tobin's Q. I follow Ferreira and Matos (2008) and calculate Tobin's Q as the total assets plus the market value of equity minus the book value of equity over the total assets.

Because a country's investor protection level also plays a role in the corporate governance quality (e.g., La Porta, Lopez-de-Silanes, Shleifer, and Vishny, 1998; 2000a, 2000b), I also control for the investors' rights at the country level. To do so, I use the revised anti-director rights index developed by Djankov, La Porta, Lopez-de-Silanes, and Shleifer (2008). ${ }^{20}$ This index is based on the original index developed by La Porta, Lopez-de-Silanes, Shleifer, and Vishny (1998) and has been updated by Djankov, La Porta, Lopez-de-Silanes, and Shleifer (2008). In general, this index represents the quality of minority shareholder protection in a country and is based on six different dimensions. Every dimension is represented by an indicator variable that equals one if the protection mechanism is in place and zero otherwise. The sum of all six dimensions for each country comprises then the revised version of the anti-director rights index and can range from zero to six in which the higher values indicate better minority shareholder protection. $^{21}$

Lastly, I also take into account the information on all of the past engagement activities. That is, I control for the number of objectives in the past year as well as for the

\footnotetext{
${ }^{19}$ Worldscope defines \% of closely held shares as the ratio of the number of closely held shares over the number of common shares outstanding. The number of closely held shares includes all "shares held by officers, directors, and their immediate families, shares held in trust, shares of the company held by any other corporations, shares held by pension/benefit plans, and shares held by individuals who hold $5 \%$ or more of the outstanding shares."

${ }^{20}$ The anti-director rights index is publicly available on Professor La Porta's website: http://mba.tuck.dartmouth.edu/pages/faculty/rafael.laporta/publications.html.

${ }^{21}$ For more details on the construction of the revised anti-director rights index see Djankov, La Porta, Lopezde-Silanes and Shleifer (2008, p. 453-456).
} 
number of milestones achieved at a given corporation. I conjecture that the level of past objectives has an influence on the current intensity of the engagements and their corresponding successes. This influence is important because the private engagements crucially depend on confidential and trustful relationships between the institutional shareholder and the investee corporation.

Appendix 4.B outlines all of the variables and their underlying calculations and definitions.

\subsubsection{Methods}

To analyze the intensity of the shareholder engagements, I look at the number of objectives at the sample corporations. Even though I focus on the priority list of corporations, they do not always display objectives. Consequently, several cases exist in which the priority corporations do not display any engagement activities in the year during which they are on the list. I adopt a Tobit regression approach to shed light on the intensity of the shareholder engagements. The main Tobit regression model has the following form:

$$
\begin{aligned}
& \text { Number of engagements } s_{i, t} \\
& =\alpha+\beta_{1}(\text { Geographic location })_{i}+\beta_{2}(\text { Past engagement characteristics })_{i, t-1} \\
& +\beta_{3}(\text { Firm }- \text { and country characteristics })_{i, t-1}+\beta_{4}(\text { Controls })_{i, t-1}
\end{aligned}
$$

where the Number of engagements is equal to the absolute number of objectives at corporation $i$ in year $t$. The dependent variable is subsample specific. That is, for the analysis of the entire sample the variable equals one if any kind of objective has been raised with the corporation, whereas for the sub-samples of ESG engagements, the variable is equal one if at least one objective exists in these subsamples. The Geographic location is a dummy variable that controls for a corporation's domicile. In the following empirical analysis, I treat the United Kingdom as the base category.

The Past engagement characteristics is a vector of past engagement variables (i.e., the number of objectives received last year and the number of milestones a corporation displays last year), Firm- and country characteristics is a vector of firm characteristics (i.e., corporation size, leverage, dividend payer indicator, past 1-year sales growth, percentage of closely held shares, and Tobin's $Q$ ), as well as the country-level characteristics (revised anti-director rights index). Lastly, the Controls is a vector of variables that control for year and industry effects. All of the explanatory variables (except for the geographical location variables) on the right-hand-side of the equation are measured at year $t-1$, and all of the continuous variables are winsorized at the $1 \%$ and $99 \%$ levels to reduce the effects of outliers.

In a second step, I research the determinants of the likelihood of successful engagements: milestones. To do so, I adopt a Tobit regression framework of the following kind: 


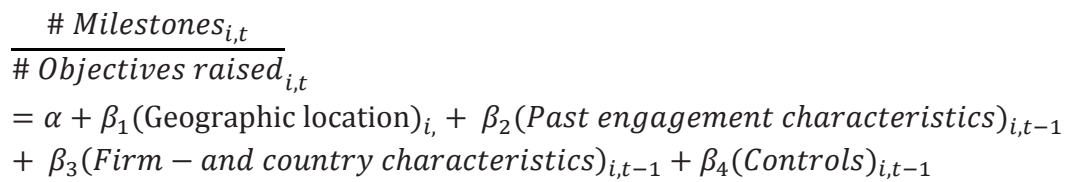

The dependent variable in this Tobit specification is the ratio of the total number of milestones achieved and the total number of objectives raised in any topic area. This gives a clean measure of success because I put the absolute number of milestones in relation to the number of objectives raised. All of the other explanatory variable vectors are defined as before.

An investigation of the absolute number of milestones (by a count model or a logistic analysis) could yield biased results as the number of milestones is ultimately driven by the number of objectives. Thus, it is important to note that I solely focus on the corporations that actually were targeted. I do so, to reduce the effect of a potential selection bias in my data. Therefore, I calculate the real probability of successful shareholder engagements. For example, a corporation that displays no objectives in 2007 is not included in the analyses, whereas a corporation with objectives in 2008 but no milestones in that particular year is assigned a zero for the value of the dependent variable.

Next, I present the empirical results of my analyses. I start with a presentation of the summary statistics on the sample of corporations.

\subsection{Empirical results}

\subsubsection{Summary statistics}

I start with a description of the temporal evolution and geographical dimension of the priority list.

\subsubsection{What does the priority list look like?}

Table 4.1 depicts the major summary statistics of the priority list. Panel A of Table 4.1 shows the temporal evolution of the priority list. One sees that the list starts in 2006 with 186 different corporations. This number of corporations develops over time; it reaches its peak in 2008 with 214 corporations and its all-time low in 2010 with 112 corporations. In 2011, the list comprises 132 corporations. There is also quite some variation in the list composition as indicated by the number of corporations that are added and dropped every year. In 2007, more corporations were added than dropped. This trend changes afterwards; from 2008 to 2010, there were always more corporations dropped than added. This trend alludes to high turnover within the priority lists. The last column of Panel A also emphasizes the fact that there is a substantial part of the added corporations that is completely new to the list. 
Table 4.1: Priority list statistics

This table shows the summary statistics on the composition of the priority list under investigation. The second column displays the number of corporations present on the yearly priority list. In the third column, I present the number of corporations that are added to the list in that year. The fourth column shows the number of corporations which are dropped at the end of that year (i.e., these corporations do not appear on the priority list one year later). Lastly, column five shows the number of corporations that appear for the first time on the priority list in that year.

\begin{tabular}{|c|c|c|c|c|}
\hline \multicolumn{5}{|c|}{ Panel A: Temporal Priority List Evolution } \\
\hline Year & \# Firms & \# added & \# dropped & $\begin{array}{l}\text { \# firms first time } \\
\text { priority list }\end{array}$ \\
\hline 2006 & 186 & - & 88 & 186 \\
\hline 2007 & 165 & 67 & 3 & 67 \\
\hline 2008 & 214 & 52 & 93 & 43 \\
\hline 2009 & 184 & 63 & 99 & 52 \\
\hline 2010 & 112 & 27 & 36 & 18 \\
\hline 2011 & 132 & 56 & - & 31 \\
\hline \multicolumn{5}{|c|}{ Panel B: Geographical Distribution of Firms } \\
\hline & \# Unique Firms & $\%$ of total & \# Firm-years & $\%$ of total \\
\hline United States & 75 & $18.9 \%$ & 211 & $21.2 \%$ \\
\hline United Kingdom & 84 & $21.2 \%$ & 240 & $24.2 \%$ \\
\hline Continental Europe & 108 & $27.2 \%$ & 285 & $28.7 \%$ \\
\hline Japan & 23 & $5.8 \%$ & 39 & $3.9 \%$ \\
\hline All Other Countries & 107 & $27.0 \%$ & 218 & $22.0 \%$ \\
\hline
\end{tabular}

Panel B of Table 4.1 provides the summary statistics of the geographical composition of the priority list. A substantial amount of the corporations originate from Continental Europe (108) and all other countries (107). Furthermore, 84 and 75 corporations originate from the United Kingdom and the United States respectively. From these figures, a direct home bias in the shareholder engagements is not visible. However, the last two columns of Panel B show a more interesting picture. There, I display the number of firmyears (column 3) and the percentage share of firm-years in the different geographical regions (column 4). I observe that the corporations from Continental Europe are most often included in the sample (285 firm-year observations or $28.7 \%$ of all firm-years), followed by corporations from the United Kingdom (240, 24.2\%), and all other countries (218). The data also show that on average the corporations from the United Kingdom are included in the priority lists 2.86 times, corporations from the United States 2.81 times, and the Continental European corporations 2.64 times. This finding points to the fact that the UK corporations seem to be the targets of the objectives by the engagement agent more often than, for example, the corporations originating from Continental Europe, Japan, and all other countries.

\subsubsection{The temporal and topical scope of engagements and successes}

The engagement intensity and success are time dependent as well. Table 4.2 provides some evidence on the temporal evolution of the engagements and successes by sub- 
topics. Panel A depicts the evolution of the engagements over time. I find that the engagement agent raised 6,837 objectives during the sample period at all 397 corporations. On a firm-year basis, this means 6.885 objectives per corporation in a given year. My results also show that the highest number of absolute objectives occurs in 2009, but the highest average number of objectives per corporation appears in 2010 with 12.69 objectives per corporation.

The following three main columns depict the same statistics for the different subsamples of ESG engagements. I see that the engagement agent is mostly active in the field of corporate governance with a total of 2,771 objectives, followed by social objectives $(2,162)$ and environmental $(1,902)$. However, this result is mostly driven by the years 2006 and 2007 in which the vast majority of objectives fell into the category of corporate governance. Starting in 2008, this picture changes. In 2008, 571 objectives were raised in the social field, followed by governance (567) and environmental objectives (388). 


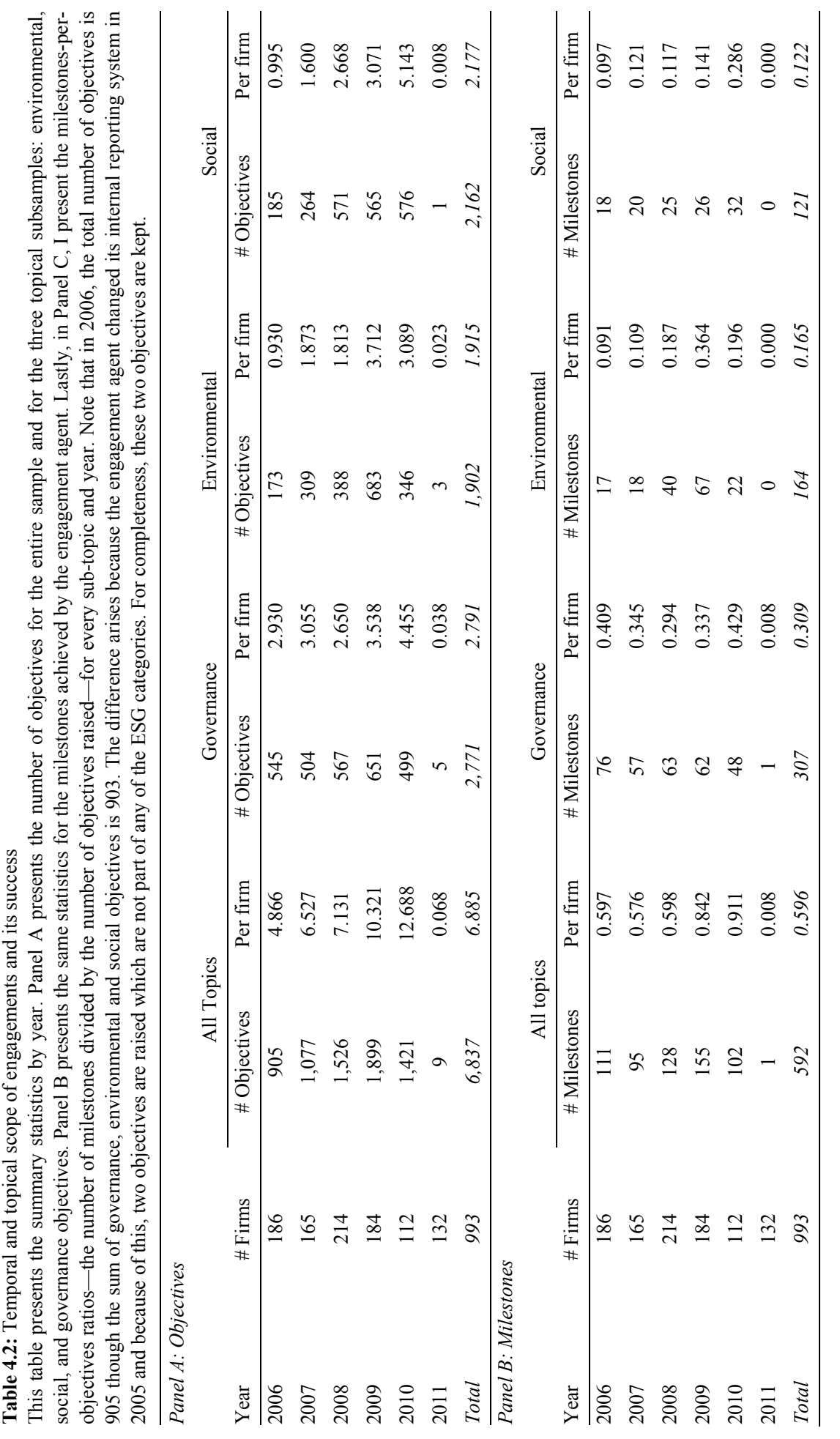


CHAPTER 4

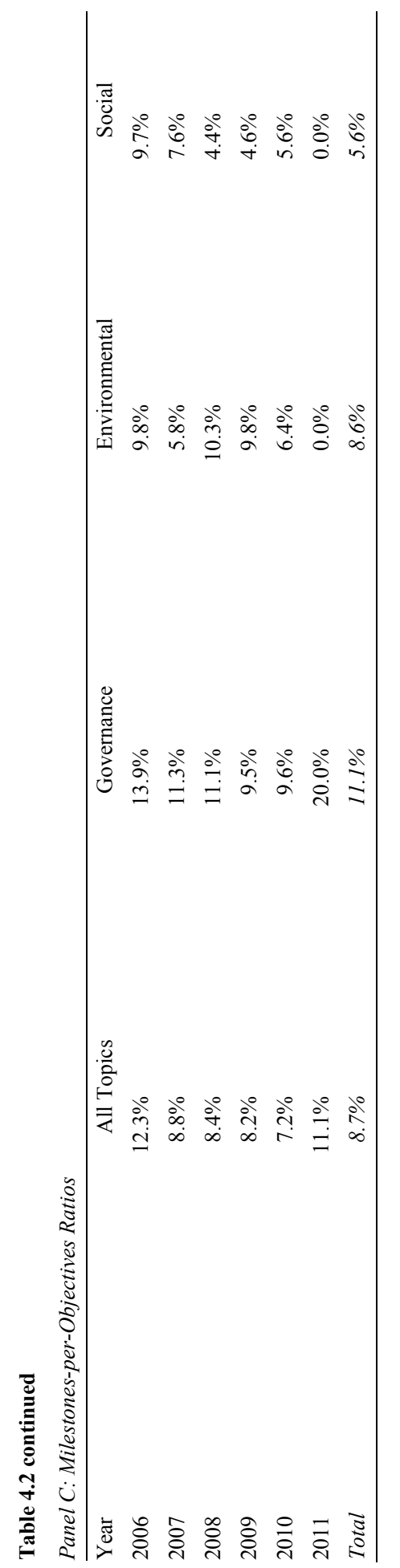


In the following year, 2009, the governance objectives were overtaken by the environmental objectives (683 vs. 651). In the last complete year of my sample, 2010, the social topics attracted the most attention with 576 objectives, followed by governance (499) and environmental (346). I conclude from this trend that the engagement agent is not only engaging with corporations on corporate governance objectives. Rather the opposite is true, the engagement agent becomes active in social and environmental topics. This finding alludes to the growing importance of the sustainable environmental and social corporate practices to the institutional shareholders.

Panel B of Table 4.2 presents the temporal evolution of the milestones for the entire sample and the three topic subsamples. Over time, the engagement agent becomes more and more effective in promoting change at investee corporations. The third and fourth column of Panel B present statistics on the entire sample. I find that the highest absolute number of milestones were achieved in 2008 and 2009 with 128 and 155 milestones respectively. On a per-firm basis, the engagement agent on average achieved almost one milestone per priority corporation in 2009 and 2010 (0.842 and 0.911 respectively). In total, the engagement agent achieved 592 milestones at 397 unique corporations (1.5 milestones per corporation on average) that equals 0.596 milestones per firm-year. Regarding the three subsamples, I find that in general, the corporate governance engagements are the most successful over the entire sample period (307 milestones). Every year, corporate governance milestones occur more frequently than the environmental and the social milestones. The only exception occurs in the year 2009 in which 67 environmental milestones were achieved with 62 governance and 26 social milestones.

In Panel C of Table 4.2, I set Panel A (objectives) and Panel B (milestones) in relation to each other. I do so to draw conclusions about the effectiveness of corporate engagement by the engagement agent. Panel $\mathrm{C}$ presents the milestones-per-objectives ratio, which is the number of milestones divided by the number of objectives raised. Hence, this ratio gives the percentage of successful engagements. Note that this measure is very conservatively chosen. It does not account for the fact that multiple objectives in a particular topic area have to be raised to achieve a milestone. A lot of engagements take place on a continuous basis, including writing multiple letters or emails about the same topic. I do not pick up this repetitive aspect of the private engagements with the milestones-per-objectives ratio.

Panel $\mathrm{C}$ indicates that the overall milestones-per-objectives ratio is $8.7 \%$. The highest ratio is achieved in 2006 with $12.3 \%{ }^{22}$ Looking at a different subsample, I find that the milestones-per-objectives ratio is always the highest for corporate governance issues. One exception is 2009 during which the environmental milestones were more often achieved in relative terms $(9.8 \%$ vs. $9.5 \%$ for governance issues). Notably, in $2008-$ 2010 , the social objectives display the lowest milestones-per-objectives ratio. Overall, I conclude that the engagement agent is successful in promoting change at the portfolio

\footnotetext{
${ }^{22}$ I do neglect the highest ratio in 2011 because I do not have the engagement information for the entire calendar year.
} 
corporations. On average, it is most successful in the governance domain of ESG, followed by environmental and social issues.

\subsubsection{The geographical dispersion of engagements and milestones}

I now turn to the summary statistics on the engagements by taking into account the geographical location of the target corporations. Table 4.3 presents the corresponding statistics. Panel A of Table 4.3 shows that the highest number of objectives appear at UK corporations $(2,159)$, followed by the US corporations and the Continental European corporations (1,783 and 1,650 respectively). However, as already noted in Table 4.1, the number of firm-years for the UK corporations is also the highest. To account for this finding, I scale the number of objectives by the number of firm-years for every geographical region/country. The result is displayed in column four of Panel A. The objectives per firm-year are the highest for the UK corporations with on average nine objectives per firm-year. The US corporations display a similar average with 8.45 objectives per firm-year. The corporations originating from Continental Europe, all other countries, and Japan display substantially less objectives per firm-year: 5.79, 5.12, and 3.31 respectively. These results point to the fact that the UK corporations receive proportionally more objectives than the corporations originating from any other geographical region.

A similar picture arises for the successful engagements. The absolute number of milestones is the highest for the corporations from the United Kingdom, the United States, and Continental Europe. Accounting for the frequency of the occurrences of these corporations in the priority lists, I find that the US corporations have the highest milestone number per firm-year with 0.82 . The UK corporations have on average 0.8 milestones per firm-year. Again, the corporations from all other countries have much fewer milestones on average. It is important to note that the Japanese corporations have the highest milestones-per-objectives ratio $(13.2 \%)$, followed by the US corporations (9.6\%), and the Continental European corporations (9.3\%). The fact that the UK corporations have a milestones-per-objectives ratio of just $8.8 \%$ and that they also get targeted more frequently implies that the UK corporations are more prone to engagements. But, it also implies that the engagement agent is not able to successfully engage with these corporations on average even though the frequency of the engagements is higher.

Panel B of Table 4.3 displays the same statistics for the three subcategories of engagement. Generally, the same patterns emerge as in Panel A. I find that the UK corporations are the most prone to ESG objectives. Further, I find that the engagement agent successfully engages on corporate governance issues at the Japanese and the US corporations, which have milestones-per-objectives ratios of $15.8 \%$ and $14.3 \%$ respectively. The environmental engagements are the most successful in the Continental European corporations $(11.2 \%)$, while the social objectives are mostly honored by the Japanese corporations $(12.5 \%)$. On the contrary, the US and the UK corporations have similar milestonesper-objectives ratios with respect to the environmental engagements (7.9 and $7.3 \%$ respectively). I also find that the US corporations are apparently not likely to honor the agent's social engagements. 


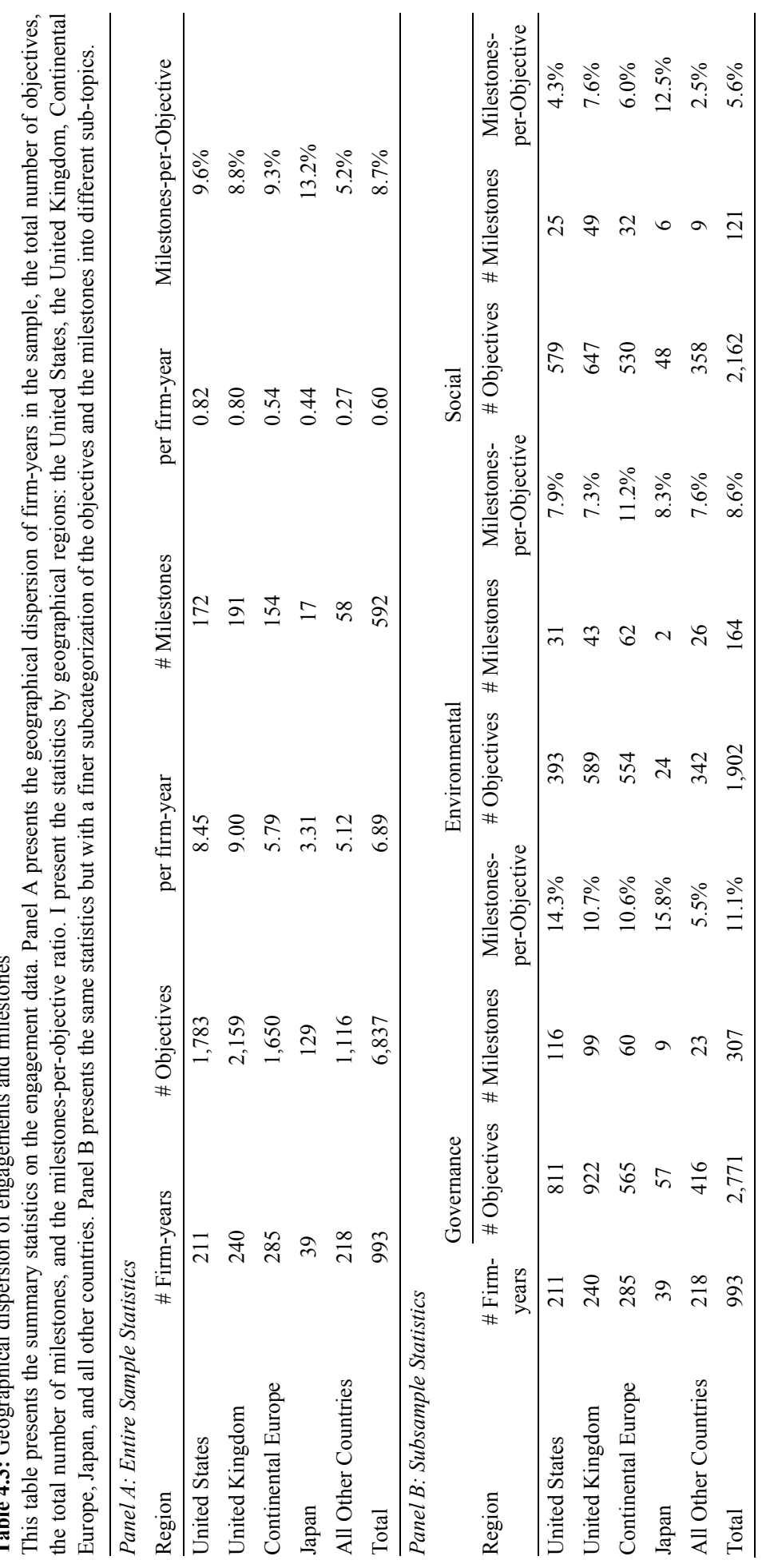


Overall, the picture that emerges from these descriptive analyses of the engagement patterns emphasizes the fact that there is quite a bit of engagement activity going on from the side of the engagement agent. I observe increasing engagement activity in the fields of the environmental and the social issues. Nonetheless, corporate governance issues dominate the engagement spectrum of the engagement agent. I also find that the UK corporations display the most objectives on a firm-year basis followed by the US corporations. The US corporations have on average the highest number of successful engagements. I find some variation in these statistics when I split the sample up into the different engagement topics of corporate governance, environmental, and social issues.

\subsubsection{Empirical analyses}

In this section, I investigate the determinants of the engagements empirically. To do so, I first present the descriptive statistics on the variables used in the analyses. Table 4.4 presents the most important statistics. This table shows that every observation displays on average 6.89 objectives and 0.6 milestones. Furthermore, the average corporation in my sample has US\$262,921 million in total assets (median value of US\$ 43,494 million). On average, the leverage ratio for my observations is equal to $23.6 \%$, the past oneyear sales growth is equal to $13 \%$, and the percentage of closely held shares is $22.9 \%$. The average Tobin's Q in my sample is 1.67 , and $91 \%$ of the corporations pay dividends. I investigate next how these statistics relate empirically to the frequency of the engagements by the engagement agent.

\subsubsection{The determinants of engagement intensity}

In the following, I present my empirical results regarding the determinants of the intensity of the engagement activities. Table 4.5 presents the main findings of this analysis. Table 4.5 presents four different Tobit regression models taking into account the entire sample of observations. In every model, the dependent variable is the absolute number of objectives that a corporation receives in a given year, irrespective of the topic that is addressed. In Model 1 of Table 4.5, I only regress the geographical variables on the number of objectives. The results of Model 1 show that all four regions have a significantly negative impact on the predicted number of objectives a corporation receives. That is, the corporations originating from these four regions receive significantly fewer objectives than the UK corporations (the base case in this analysis). To illustrate the economic differences in the engagement intensity, I present the predicted number of engagements based on the relevant fitted empirical model. Model 1 predicts that a UK corporation receives 6.77 objectives while a US corporation hypothetically gets 4.53 objectives. Hence, corporations originating from the United States receive on average 2.24 less objectives in a given year than a UK corporation. An average Continental European corporation receives just 1.54 objectives, as predicted by this empirical model. Given these results, I find supportive evidence for my first research hypothesis, H4.1: the UK corporations receive significantly more objectives than the non-UK corporations. However, I so far do not control for any other firm characteristics that might influence the engagement intensity. This is now done in Model 2. 
Table 4.4: Descriptive statistics

This table presents the summary statistics on the variables used in the empirical analyses. The main data source for firm-level financial variables is Worldscope. The information on the number of objectives as well as on the number of milestones comes directly from the institutional investor. Continuous variables have been winsorized at $1 \%$ and $99 \%$.

\begin{tabular}{lcccc}
\hline Variable & Obs. & Mean & Median & St. Dev. \\
\hline United States & 993 & 0.212 & 0.000 & 0.409 \\
Continental Europe & 993 & 0.287 & 0.000 & 0.453 \\
Japan & 993 & 0.039 & 0.000 & 0.194 \\
Rest of World & 993 & 0.220 & 0.000 & 0.414 \\
UK & 993 & 0.242 & 0.000 & 0.428 \\
\# Objectives & 993 & 6.885 & 4.000 & 9.570 \\
\# Milestones & 993 & 0.596 & 0.000 & 1.012 \\
Revised Anti-Director Rights Index & 991 & 3.892 & 4.000 & 1.042 \\
Total Assets (\$ mil.) & 983 & $262,921.10$ & $43,493.62$ & $572,123.50$ \\
Log (1+Total Assets) & 983 & 10.669 & 10.680 & 2.009 \\
Total Debt / Total Assets (\%) & 983 & 0.236 & 0.225 & 0.145 \\
Dividend payer dummy & 983 & 0.910 & 1.000 & 0.286 \\
Past 1-year sales growth (\%) & 982 & 0.130 & 0.098 & 0.247 \\
Closely held shares (\%) & 942 & 0.229 & 0.133 & 0.257 \\
Tobin's Q & 982 & 1.666 & 1.334 & 1.092 \\
\hline
\end{tabular}

In Model 2, I additionally control for firm characteristics. The addition of these variables does not materially change the results for the geographical control variables. I now find even stronger results in favor of my home bias hypothesis, H4.1: non-UK corporations receive significantly fewer objectives than the UK corporations that implies that the engagement agent is much more active at the UK corporations. My model predicts that on average a UK corporation on the priority list receives 6.96 objectives while a US or Continental European corporation displays a predicted number of objectives: 2.59, and 0.32 respectively. Furthermore, in absolute terms, an average Japanese corporation gets 9.62 objectives less in a particular year than a UK corporation. Overall, these results allude to a home bias in the engagement intensity.

Regarding the firm characteristics influencing the intensity of the engagement, I find that the larger corporations receive significantly more objectives than the smaller corporations. This is supporting evidence in favor of my second research hypothesis, H4.2. Two explanations are possible for this result. First, the larger and more visible corporations are simply more often included in the institutional clients' portfolios and hence, are also more likely to be frequently targeted. Secondly, the larger and more visible corporations are possibly more responsive to the shareholder engagements. Thus, the engagement agent focuses its engagement activities on these corporations because the expected likelihood of engagement success also drives the investor's engagement decision. 


\section{CHAPTER 4}

Table 4.5: Determinants of engagement intensity

This table shows the four different Tobit models. In each of those models, the dependent variable is the total number of objectives a corporation receives from the engagement agent. All independent variables are measured at $t-1$, one year before the engagement takes place. All continuous variables are winsorized at the $1 \%$ and 99\% level respectively. In all models, I control for time and industry effects. Standard errors are robust and ***,**, and * indicate statistical significance at the $1 \%, 5 \%$, and $10 \%$ levels respectively. Robust P-values are presented below the coefficients in parentheses.

\begin{tabular}{|c|c|c|c|c|}
\hline & Model 1 & Model 2 & Model 3 & Model 4 \\
\hline \multirow[t]{2}{*}{ United States } & $-2.241^{*}$ & $-4.371 * * *$ & -2.123 & -0.896 \\
\hline & $(0.072)$ & $(0.000)$ & $(0.191)$ & $(0.573)$ \\
\hline \multirow[t]{2}{*}{ Continental Europe } & $-5.234 * * *$ & $-6.632 * * *$ & $-4.871 * * *$ & $-2.523 *$ \\
\hline & $(0.000)$ & $(0.000)$ & $(0.001)$ & $(0.062)$ \\
\hline \multirow[t]{2}{*}{ Japan } & $-7.693 * * *$ & $-9.616 * * *$ & $-8.988 * * *$ & $-5.252 * *$ \\
\hline & $(0.000)$ & $(0.000)$ & $(0.000)$ & $(0.011)$ \\
\hline \multirow[t]{2}{*}{ All Other Countries } & $-7.954 * * *$ & $-5.258 * * *$ & $-4.225 * * *$ & -1.464 \\
\hline & $(0.000)$ & $(0.000)$ & $(0.003)$ & $(0.281)$ \\
\hline \multirow[t]{2}{*}{ \# Objectives t-1 } & & & & $0.337 * * *$ \\
\hline & & & & $(0.000)$ \\
\hline \multirow[t]{2}{*}{ \# Milestones t-1 } & & & & $0.844^{* *}$ \\
\hline & & & & $(0.013)$ \\
\hline \multirow[t]{2}{*}{ \# Years on priority list } & & & & 0.295 \\
\hline & & & & $(0.499)$ \\
\hline \multirow[t]{2}{*}{ Anti-director rights index } & & & $1.155^{* *}$ & 0.589 \\
\hline & & & $(0.042)$ & $(0.304)$ \\
\hline \multirow[t]{2}{*}{ Firm size } & & $2.488 * * *$ & $2.573 * * *$ & $1.505 * * *$ \\
\hline & & $(0.000)$ & $(0.000)$ & $(0.000)$ \\
\hline \multirow[t]{2}{*}{ Leverage } & & $-4.227 *$ & $-4.431^{*}$ & -2.726 \\
\hline & & $(0.074)$ & $(0.061)$ & $(0.231)$ \\
\hline \multirow[t]{2}{*}{ Dividend payer? } & & 1.259 & 1.027 & 0.944 \\
\hline & & $(0.374)$ & $(0.470)$ & $(0.462)$ \\
\hline \multirow[t]{2}{*}{ 1yr sales growth } & & $-3.077 * *$ & $-3.194 * *$ & $-2.443 * *$ \\
\hline & & $(0.019)$ & $(0.016)$ & $(0.048)$ \\
\hline \multirow[t]{2}{*}{ Closely held shares (\%) } & & $-3.986^{* *}$ & $-3.542 *$ & $-3.357^{*}$ \\
\hline & & $(0.038)$ & $(0.063)$ & $(0.082)$ \\
\hline \multirow[t]{2}{*}{ Tobin's Q } & & 0.283 & 0.323 & 0.207 \\
\hline & & $(0.237)$ & $(0.179)$ & $(0.384)$ \\
\hline \multirow[t]{2}{*}{ Constant } & $-25.578 * * *$ & $-50.563 * * *$ & $-57.568 * * *$ & $-50.701 * * *$ \\
\hline & $(0.000)$ & $(0.000)$ & $(0.000)$ & $(0.000)$ \\
\hline Number of Observations & 939 & 882 & 882 & 882 \\
\hline Pseudo R-Squared & 0.082 & 0.100 & 0.101 & 0.119 \\
\hline
\end{tabular}

My results also indicate that leverage is negatively related to the presence of the engagements, implying that highly levered corporations receive significantly fewer engagement objectives. This result is consistent with Jensen (1986) who argues that leverage can act as a corporate governance device in restricting managers from making un- 
profitable investments. Consistent with the evidence on engagement through shareholder proposals (see, e.g., Chapter 2), I find that the less profitable corporations are more often the target of the engagements by the engagement agent. The negative and significant coefficient on the 1yr sales growth variable means that the more profitable corporations receive fewer objectives than the less profitable corporations (or corporations with a negative sales growth over the previous year). I also document a negative and significant relation between the percentage of closely held shares and the engagement intensity. This result implies that the corporations that have a more concentrated shareholder base of corporate insiders, other corporations, and pension plans receive significantly fewer objectives than the corporations with a more dispersed ownership structure. I argue that more ownership in the hands of the corporate insiders and the pension plans make the other institutional investors less likely to engage with such corporations. The reasoning is that there might already be some engagement going on from other investors on similar topics that makes the engagement agent's additional engagement redundant. This explanation is very similar to the well-known free-riding problem in corporate finance as established by Grossman and Hart (1980).

In the remaining models of Table 4.5, I also control for the country-level governance quality and the past engagement activities at investee corporations to establish a clear relation between the geography and the engagement intensity. In particular, Model 3 controls for the revised version of the anti-director rights index as constructed by Djankov, La Porta, Lopez-de-Silanes, and Shleifer (2008). As Model 3 shows, the index itself is positively and significantly related to the engagement intensity. It suggests that the engagement intensity is significantly higher in the countries where the minority shareholders are better protected. The inclusion of this country-level variable changes my previous geographic results slightly. Still, the corporations from the non-UK countries receive significantly fewer objectives than the UK corporations. However, the coefficient on the US dummy variable becomes nonsignificant, yet still negative. Hence, my main conclusion about a home bias still holds.

In Model 4, I also control for the past engagement activities of the engagement agent at investee corporations as well as for the number of years a corporation was on the priority list before the engagement took place. Essentially, all of the signs of the coefficients from Model 3 remain the same. However, the average size US corporations and the average size corporations originating from all other countries receive insignificantly fewer objectives than the average UK corporation.

My remaining results suggest that the past engagement activities at the corporations increase the number of objectives an investee corporation receives in the current period. For example, assuming that an investee corporation gets ten more objectives in period $t$ 1 , this increases the number of objectives in period $t_{0}$ by 3.37 . Similarly, if a corporation displays one more milestone in the past period $t-1$, then it receives 0.844 more objectives in the current period $t_{0}$. These results allude to the evolution of a relationship between the engagement agent and its investee corporations. The more objectives and milestones a particular priority list corporation has in a particular year, the higher the engagement intensity in the subsequent year. The number of years on the priority list prior to the engagement does not influence the engagement intensity. 
The results with respect to the firm characteristics remain largely unaffected by the inclusion of the anti-director rights index and the past engagement activities in Models 3 and 4.

Overall, the results of Table 4.5 indicate a home bias in the engagement intensity. The UK corporations receive significantly more objectives than the corporations from the United States, Japan, Continental Europe, and all other countries. My results support hypotheses H4.1, and H4.2.

\subsubsection{Is the size effect persistent across countries and regions?}

In the analysis so far, I hypothesize that the larger corporations receive significantly more objectives than the smaller corporations. The coefficient on my firm size variable is positive and significant as Table 4.5 shows. However, this coefficient represents the average effect of firm size on the engagement intensity. I cannot judge whether this effect also holds for different sub-regions and countries as well. Therefore, Table 4.6 provides some more statistics on the size of my sample corporations within different regions and countries. Panel A of Table 4.6 presents some summary statistics on the distribution of firm sizes in different countries and regions. The median firm sizes for the different regions and countries are quite similar. The median Continental European corporation is the largest among all five different regions, followed by the Japanese, US, and the UK corporations. I also find that the sample of the UK corporations has the widest spread between the smallest and the largest corporations, which indicates that the engagement agent targets a very wide spectrum of UK corporations. In contrast, the spread between the largest and smallest corporations in the other regions is much smaller.

Panel B presents the average number of objectives for the corporations in the different size quantiles. Panel B of Table 4.6 discloses that there is a size effect present in all five regions and countries except for Japan. I find that the difference in the average number of objectives between the largest and the smallest size quantiles is significant at the $1 \%$ level in the United Kingdom and the United States and at the $10 \%$ level in Continental Europe and at the 5\% level in all other countries in the sample. For the United Kingdom and the United States, I even find that the second and fourth size quantiles receive on average significantly more objectives than the first and third quartiles. I conclude that firm size is an important driver of the engagement intensity. ${ }^{23}$

\footnotetext{
${ }^{23}$ I do find similar results for the effect of corporate size on the engagement intensity in Tobit regressions for the five geographic subsamples by regressing the total number of objectives on those control variables included in Model 4 of Table 4.5. Similarly, the results do not materially differ when I add an ordinal variable ranging from 1-5 for each size quintile per geographical region as the independent size variable. The size effect remains significant and positive implying that larger corporations receive substantially more engagements despite the different distributions of the size variable in different geographical regions.
} 


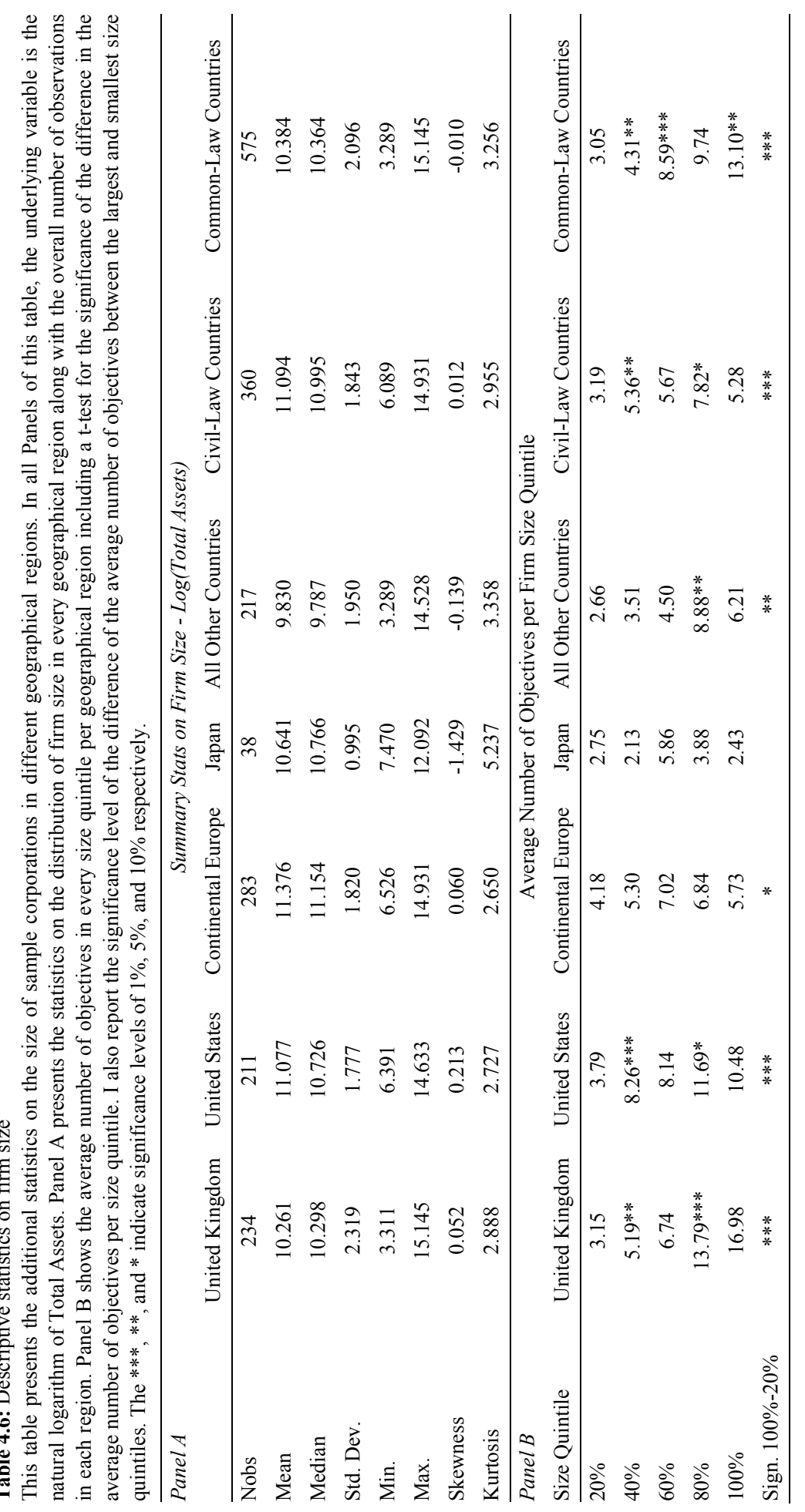




\subsubsection{The determinants of engagement intensity in ESG topics}

The results of the analysis in Table 4.5 hold for the entire sample of the engagements. Do the same geographical patterns hold for the three subsamples of corporate governance, environmental, and social engagements as well? To answer this question, I undertake the same analysis for these three subsamples. Table 4.7 presents the results. In Model 1 of Table 4.7, I study the intensity of corporate governance engagements, while in Models 2 and 3 I investigate social and environmental engagements respectively. ${ }^{24}$ For the number of corporate governance objectives, I find similar results as for the entire sample. Relative to the UK corporations, the Continental European and the Japanese corporations receive significantly fewer objectives. Looking at the results for the social objectives, I find nonsignificant influences for the geographical locations of the target corporations on the engagement intensity.

This finding could imply that the social standards are of equal importance at all of the corporations irrespective of the corporation's country or region of origin. The implementation of certain social policies is therefore not necessarily driven by the geographic locations of the corporations. Another explanation could be that national regulations regarding social policies might not be that much stronger than the national standards on governance and environmental standards.

With respect to environmental objectives, I find that the Japanese corporations receive significantly fewer objectives than the UK corporations. Additionally, the results suggest that the larger corporations receive significantly more objectives of any kind than their smaller counterparts.

Taken together, these findings reinforce my previous finding of a home bias in the engagements. However, the results for the entire sample are much stronger in statistical and economic terms. These results seem to be driven especially by corporate governance and environmental engagements, as Table 4.7 suggests.

\footnotetext{
${ }^{24}$ The analyses conducted in Table 4.7 use exactly the same models as in Table 4.5. I replace the two variables total number of objectives and milestones in $t-1$ with the total number of objectives/milestones for every subcategory of engagements. Furthermore, as robustness, I also control in unreported results for the simultaneous presence of ESG engagements. The results do not substantially differ.
} 
Table 4.7: Determinants of engagement intensity per theme

This table shows three different Tobit models. In Model 1, the dependent variable is equal to the number of corporate governance $(\mathrm{CG})$ objectives a corporation receives in a given year, in Model 2 the dependent variable is the total number of social objectives, and in Model 3 the dependent variable is the number of environmental objectives. All independent variables are measured at $t-1$, one year before the engagement takes place. All continuous variables are winsorized at the $1 \%$ and $99 \%$ levels respectively. In all models, I control for time and industry effects. Standard errors are robust and ***, **, and * indicate statistical significance at the $1 \%$, $5 \%$, and $10 \%$ levels respectively. P-values are presented below the coefficients in parentheses.

\begin{tabular}{|c|c|c|c|}
\hline & $\begin{array}{c}\text { Model 1: } \\
\text { Governance }\end{array}$ & $\begin{array}{l}\text { Model 2: } \\
\text { Social }\end{array}$ & $\begin{array}{c}\text { Model 3: } \\
\text { Environmental }\end{array}$ \\
\hline \multirow[t]{2}{*}{ United States } & -0.096 & -0.130 & -0.600 \\
\hline & $(0.904)$ & $(0.877)$ & $(0.438)$ \\
\hline \multirow[t]{2}{*}{ Continental Europe } & $-1.797 * *$ & -0.623 & -0.656 \\
\hline & $(0.010)$ & $(0.383)$ & $(0.305)$ \\
\hline \multirow[t]{2}{*}{ Japan } & $-1.887^{*}$ & -1.518 & $-3.655 * * *$ \\
\hline & $(0.058)$ & $(0.197)$ & $(0.002)$ \\
\hline \multirow[t]{2}{*}{ All Other Countries } & -0.621 & -0.452 & -0.766 \\
\hline & $(0.366)$ & $(0.555)$ & $(0.252)$ \\
\hline \multirow[t]{2}{*}{ \# Objectives (per topic) t-1 } & $0.367 * * *$ & $0.355 * * *$ & $0.289 * * *$ \\
\hline & $(0.000)$ & $(0.000)$ & $(0.001)$ \\
\hline \multirow[t]{2}{*}{ \# Milestones (per topic) t-1 } & $0.820 * * *$ & $1.187 * *$ & $0.840^{*}$ \\
\hline & $(0.008)$ & $(0.026)$ & $(0.099)$ \\
\hline \multirow[t]{2}{*}{ \# Years on priority list } & 0.238 & $0.472 *$ & -0.147 \\
\hline & $(0.258)$ & $(0.066)$ & $(0.479)$ \\
\hline \multirow[t]{2}{*}{ Anti-Director Rights Index } & 0.202 & 0.288 & $0.481 *$ \\
\hline & $(0.457)$ & $(0.301)$ & $(0.079)$ \\
\hline \multirow[t]{2}{*}{ Firm Size } & $0.811^{* * *}$ & $0.573 * * *$ & $0.671 * * *$ \\
\hline & $(0.000)$ & $(0.001)$ & $(0.000)$ \\
\hline \multirow[t]{2}{*}{ Leverage } & 0.556 & -1.602 & -1.842 \\
\hline & $(0.658)$ & $(0.286)$ & $(0.114)$ \\
\hline \multirow[t]{2}{*}{ Dividend Payer? } & 0.423 & 1.000 & -0.310 \\
\hline & $(0.537)$ & $(0.157)$ & $(0.655)$ \\
\hline \multirow[t]{2}{*}{ 1yr Sales Growth } & $-1.022 *$ & -0.168 & $-1.714 * *$ \\
\hline & $(0.083)$ & $(0.826)$ & $(0.016)$ \\
\hline \multirow[t]{2}{*}{ Closely held Shares (\%) } & -0.538 & -1.543 & -1.315 \\
\hline & $(0.557)$ & $(0.139)$ & $(0.185)$ \\
\hline \multirow[t]{2}{*}{ Tobin's Q } & 0.019 & 0.219 & -0.025 \\
\hline & $(0.891)$ & $(0.112)$ & $(0.869)$ \\
\hline \multirow[t]{2}{*}{ Constant } & $-25.645 * * *$ & $-30.076 * * *$ & $-21.237 * * *$ \\
\hline & $(0.000)$ & $(0.000)$ & $(0.000)$ \\
\hline Number of Observations & 882 & 882 & 882 \\
\hline Pseudo R-Squared & 0.137 & 0.140 & 0.139 \\
\hline
\end{tabular}




\subsubsection{Is geography or legal jurisdiction the underlying driver of engagement intensity?}

The corporate finance literature shows that the jurisdiction of the incorporation matters when it comes to corporate financing decisions and corporate governance structures. La Porta, Lopez-de-Silanes, Shleifer, and Vishny (1998) draw an important distinction between the common-law and the civil-law countries. The authors show that the corporations from common-law countries are generally exposed to better investor protection. In order to rule out the possibility that the effect of the geographical locations of the priority corporations on the engagement intensity is driven by the legal jurisdiction, and hence the target corporation's exposure level to investor protection, I conduct a robustness check. This analysis draws on the models specified in the previous section. Now, I replace the geographical locations of the target corporations with a binary variable indicating whether the corporation originates from a common- or civil-law country. I focus only on all of the non-UK corporations to get the unbiased effect of the legal jurisdiction on the engagement intensity. Table 4.8 presents the results of this exercise. 
Table 4.8: Additional analysis: Legal jurisdiction

This table shows the results of one Tobit model. The dependent variable is the absolute number of objectives a corporation receives. All independent variables are measured at $t-1$, one year before the engagement takes place. All continuous variables are winsorized at the $1 \%$ and $99 \%$ levels respectively. I control for industry and year effects. The models displayed here just take corporations into account that originate from countries other than the UK. Standard errors are robust and ***,**, and * indicate statistical significance at the $1 \%, 5 \%$, and $10 \%$ levels respectively. P-values are presented below the coefficients in parentheses.

\begin{tabular}{|c|c|}
\hline Dependent Variable: & Number of Objectives \\
\hline \multirow[t]{2}{*}{ Civil-Law Country } & -1.074 \\
\hline & $(0.198)$ \\
\hline \multirow[t]{2}{*}{ \# Objectives t-1 } & $0.250 * * *$ \\
\hline & $(0.001)$ \\
\hline \multirow[t]{2}{*}{ \# Milestones t-1 } & $0.790 * *$ \\
\hline & $(0.041)$ \\
\hline \multirow[t]{2}{*}{ \# Years on Priority List } & $0.921 * *$ \\
\hline & $(0.038)$ \\
\hline \multirow[t]{2}{*}{ Anti-Director Right Index } & 0.798 \\
\hline & $(0.154)$ \\
\hline \multirow[t]{2}{*}{ Firm Size } & $1.153 * * *$ \\
\hline & $(0.001)$ \\
\hline \multirow[t]{2}{*}{ Leverage } & -3.853 \\
\hline & $(0.171)$ \\
\hline \multirow[t]{2}{*}{ Dividend Payer? } & 0.418 \\
\hline & $(0.787)$ \\
\hline \multirow[t]{2}{*}{ 1yr Sales Growth } & $-3.360^{*}$ \\
\hline & $(0.077)$ \\
\hline \multirow[t]{2}{*}{ Closely held Shares (\%) } & $-5.115^{* *}$ \\
\hline & $(0.012)$ \\
\hline \multirow[t]{2}{*}{ Tobin's Q } & 0.287 \\
\hline & $(0.236)$ \\
\hline \multirow[t]{2}{*}{ Constant } & $-44.473 * * *$ \\
\hline & $(0.000)$ \\
\hline Number of Observations & 632 \\
\hline Pseudo R-Squared & 0.118 \\
\hline
\end{tabular}

The results suggest that the legal jurisdiction of a priority corporation's home country does not have a significant influence on the engagement intensity. I argue that this result implies that it is a priority corporation's geographical location that matters for the engagement intensity and not the legal jurisdiction of the corporation's home country. 


\subsubsection{Determinants of engagement success}

Having established the relation between geography and the occurrence of the engagements, I now turn to the analysis of the determinants of the successful engagements. In essence, I want to answer the question on whether geography also influences the success of the engagements (hypothesis H4.3).

To do so, I undertake the same analyses as before, that is, the empirical structure of my regression models remains the same except for the dependent variable. In all of the analyses that follow, the dependent variable is the milestones-per-objectives ratio. Table 4.9 presents the main findings of this analysis in four models. Model 1 focuses on the entire sample, Model 2 on corporate governance milestones, Model 3 on the social milestones, and Model 4 on the environmental milestones. Note that I focus only on firmyears in which the corporations were actually targeted. Hence, I just include the observations conditional on having at least one objective. Therefore, the number of observations is lower than in Tables 4.5 and 4.7.

What becomes apparent from the four different models is that geography is also an important determinant of the engagement success. For example, Model 1 shows that an average US corporation has a 12.4 percentage points higher milestones-per-objectives ratio than the average UK corporation. Similarly, a Continental European corporation has a 2 percentage points higher milestones-per-objectives ratio than an average UK corporation. The corporations originating from all other countries have a 17.4 percentage points lower success ratio. These results imply that even though the foreign corporations get relatively fewer engagements than the UK corporations, the engagement activities of the engagement agent are somewhat more successful in the United States and Continental Europe than in the United Kingdom. I conclude that this effect is mostly attributable to the home bias effect documented in the engagement intensity. Thus, the engagement agent very carefully selects foreign target corporations for which the expected likelihood of success is the highest.

In Model 2 of Table 4.9, I focus on corporate governance engagement successes. The results are very similar to those of the entire sample. A US corporation has a 47.8 percentage point higher success ratio than a UK corporation when it comes to corporate governance engagements. Similarly, the Continental European and Japanese corporations have 21.6 and 6.5 percentage points higher success ratios than the UK corporations. Again, the corporations from all other countries have a lower success rate than the UK corporations exposed to corporate governance engagements.

Regarding social engagements (Model 3 of Table 4.9), my results show that the Japanese corporations on average have the highest milestones-per-objectives ratio. More specifically, these corporations display on average a 14.6 percentage points higher success ratio than the UK corporations. In contrast, the US corporations, the Continental European corporations, as well as the corporations originating from all other countries in the sample have significantly lower milestones-per-objectives ratios. 
Table 4.9: Determinants of engagement success

This table presents for different Tobit models. The dependent variable is the ratio of milestones to the number of objectives raised at a given corporation in a given year. Model 1 studies all engagement themes, while the dependent variable varies from Model 2 to Model 4 according to the engagement theme under investigation (governance, social, or environmental). All independent variables are measured at $t-1$, one year before the engagement takes place. All continuous variables are winsorized at the $1 \%$ and $99 \%$ levels respectively. In all models, I control for time and industry effects. Standard errors are robust and ***, **, and * indicate statistical significance at the $1 \%, 5 \%$, and $10 \%$ levels respectively. P-values are presented below the coefficients in parentheses.

\begin{tabular}{|c|c|c|c|c|}
\hline & $\begin{array}{c}\text { Model 1: } \\
\text { Entire sample }\end{array}$ & $\begin{array}{c}\text { Model 2: } \\
\text { Governance }\end{array}$ & $\begin{array}{c}\text { Model 3: } \\
\text { Social }\end{array}$ & $\begin{array}{c}\text { Model 4: } \\
\text { Environmental }\end{array}$ \\
\hline \multirow[t]{2}{*}{ United States } & $0.124 * * *$ & $0.478 * * *$ & $-0.468 * * *$ & $0.260 * * *$ \\
\hline & $(0.000)$ & $(0.000)$ & $(0.000)$ & $(0.000)$ \\
\hline \multirow[t]{2}{*}{ Continental Europe } & $0.020 * *$ & $0.216^{* * *}$ & $-0.372 * * *$ & $0.374 * * *$ \\
\hline & $(0.025)$ & $(0.000)$ & $(0.000)$ & $(0.000)$ \\
\hline \multirow[t]{2}{*}{ Japan } & 0.007 & $0.065 * *$ & $0.146 * * *$ & $0.172 * * *$ \\
\hline & $(0.587)$ & $(0.010)$ & $(0.000)$ & $(0.000)$ \\
\hline \multirow[t]{2}{*}{ All Other Countries } & $-0.174 * * *$ & $-0.299 * * *$ & $-0.737 * * *$ & $0.080 * * *$ \\
\hline & $(0.000)$ & $(0.000)$ & $(0.000)$ & $(0.005)$ \\
\hline \multirow[t]{2}{*}{ \# Objectives (per topic) t-1 } & $0.004 * * *$ & $0.017 * * *$ & $0.022 * * *$ & $0.021 * * *$ \\
\hline & $(0.000)$ & $(0.000)$ & $(0.000)$ & $(0.000)$ \\
\hline \multirow[t]{2}{*}{ \# Milestones (per topic) t-1 } & $0.008 * *$ & $0.022 * *$ & $-0.058 * * *$ & $-0.058 * * *$ \\
\hline & $(0.012)$ & $(0.014)$ & $(0.001)$ & $(0.001)$ \\
\hline \multirow[t]{2}{*}{ \# Years on Priority List } & $0.014 * * *$ & -0.013 & $0.130 * * *$ & $0.062 * * *$ \\
\hline & $(0.001)$ & $(0.141)$ & $(0.000)$ & $(0.000)$ \\
\hline \multirow[t]{2}{*}{ Anti-Director Rights Index } & $0.039 * * *$ & $0.132 * * *$ & $-0.073 * * *$ & $0.156 * * *$ \\
\hline & $(0.000)$ & $(0.000)$ & $(0.000)$ & $(0.000)$ \\
\hline \multirow[t]{2}{*}{ Firm Size } & $0.003 * * *$ & 0.004 & $0.027 * * *$ & $0.045 * * *$ \\
\hline & $(0.009)$ & $(0.112)$ & $(0.000)$ & $(0.000)$ \\
\hline \multirow[t]{2}{*}{ Leverage } & $0.090 * * *$ & $0.173 * *$ & $0.318 * * *$ & -0.026 \\
\hline & $(0.009)$ & $(0.015)$ & $(0.004)$ & $(0.772)$ \\
\hline \multirow[t]{2}{*}{ Dividend Payer? } & $0.152^{* * *}$ & $0.266^{* * *}$ & 0.051 & $0.317 * * *$ \\
\hline & $(0.000)$ & $(0.000)$ & $(0.174)$ & $(0.000)$ \\
\hline \multirow[t]{2}{*}{ 1yr Sales Growth } & -0.012 & $0.151 * * *$ & -0.016 & -0.004 \\
\hline & $(0.448)$ & $(0.000)$ & $(0.695)$ & $(0.934)$ \\
\hline \multirow[t]{2}{*}{ Closely held Shares (\%) } & 0.030 & $0.092 *$ & $0.254 * * *$ & $0.097 *$ \\
\hline & $(0.201)$ & $(0.071)$ & $(0.000)$ & $(0.090)$ \\
\hline \multirow[t]{2}{*}{ Tobin's Q } & 0.005 & $0.025^{* * *}$ & 0.000 & $0.047 * * *$ \\
\hline & $(0.165)$ & $(0.001)$ & $(0.998)$ & $(0.000)$ \\
\hline \multirow[t]{2}{*}{ Constant } & $-2.786 * * *$ & $-4.837 * * *$ & $-4.122 * * *$ & $-6.365 * * *$ \\
\hline & $(0.000)$ & $(0.000)$ & $(0.000)$ & $(0.000)$ \\
\hline Number of Observations & 621 & 526 & 443 & 443 \\
\hline Pseudo R-Squared & 0.092 & 0.103 & 0.117 & 0.088 \\
\hline
\end{tabular}


Lastly, the results of Model 4 indicate that the corporations that domicile in another country other than the United Kingdom have significantly higher success ratios with respect to environmental engagements. In particular, the corporations from the Continental European area display on average a 37.4 percentage points higher milestones-perobjectives ratio relative to the UK corporations. Hence, one could argue that the UK corporations are the least responsive corporations in the sample, or that the engagement agent is the least successful in changing corporate environmental policies at the UK corporations.

My results also show that the engagement success is driven by the number of the objectives the corporation received over the last period, the number of milestones achieved in the previous year (except for social milestones), and the number of times a corporation has appeared on the priority list (except corporate governance). This finding supports my argument that the successful shareholder engagements by the engagement agent heavily depend on the relationship that the agent established with the target corporation in the past: continuous engagements lead to milestones.

I also find that firm size increases the success ratios of the social and the environmental engagements but not for the governance engagements. Further, leverage has a positive impact on the success of the governance and the social engagements, but not on the environmental engagements. In addition, my results emphasize the importance of the past performance for the success of the governance engagements: well-performing corporations have higher success ratios with regards to governance engagements, but not to the other two subcategories of engagement. The engagement success is also positively related to the percentage of closely held shares. The success ratios of any kind of engagement topic are higher when the percentage of closely held shares is also high. Lastly, it is important to mention that Tobin's Q is positively related to the success ratios of the governance and the environmental engagements.

Overall, I conclude from the analyses of the successful engagements that the geographic location of the priority corporations is also an important determinant of the engagement success. I find that the results for the entire sample of the engagements are mainly driven by corporate governance engagements. On average, when the corporations originate from the United States, Continental Europe, or Japan, then these originations have a significant and positive effect on the milestones-per-objectives ratio for corporate governance engagements. The same conclusion can be drawn for environmental engagements.

\subsection{Summary and concluding comments}

Nowadays, shareholder engagement is seen as a viable corporate governance mechanism by many institutional investors. They view engagement as a means to influence corporate behavior and policies with respect to ESG objectives. In this chapter, I study the global engagement activities of a large UK asset manager. On behalf of several institu- 
tional clients, the asset manager engages directly with the portfolio corporations via emails, telephone calls, personal management meetings, and letter writing.

I investigate 397 priority corporations from 37 different countries over the period of 2006-2011. My main findings show a geographical pattern in the intensity of the engagement activities. The corporations incorporated in the United Kingdom receive significantly more objectives than the corporations originating from other countries. This is consistent with hypothesis H4.1. The results suggest that there is a home bias in engagements. Moreover, my results indicate that the larger corporations receive significantly more objectives relative to their smaller counterparts that is consistent with hypothesis H4.2.

Throughout my empirical analysis, I also find that the engagement relationship between the engagement agent and its portfolio corporations is a significant driver of the engagements' presence. More specifically, the number of past engagements significantly increases the number of objectives that the same corporation receives in the future. This finding alludes to the fact that the engagement business is also driven by long-term relationship building between the corporations and their major institutional shareholders.

Regarding the determinants of the successful engagements, I show that the extent of the engagement success is also influenced by geographic factors. On average, the US as well as the Continental European corporations have significantly higher success rates than their UK counterparts. These rates also hold for the subsample of governance milestones. In contrast, the Japanese corporations on average display significantly higher social success ratios than the corporations from any other geographical region. I also establish the finding that the Continental European corporations have the highest success ratios regarding environmental engagements, followed by the US and Japanese corporations. Hence, I conclude that my results do not support hypothesis H4.3. Rather the contrary is true: the corporations originating from the United States and Continental Europe have higher success ratios (especially within governance and environmental engagements) than their UK counterparts. An explanation for this important finding could be the fact that the engagement agent is targeting in particular those foreign corporations for which the necessity of engagement is also the highest and those that therefore have the highest potential to change. Hence, the engagement agent applies greater scrutiny to select the foreign engagement targets for which it expects the highest payoff in terms of change. An alternative explanation could be that the corporations from the United Kingdom have tight nationwide regulation with respect to the governance and the environmental standards in which the potential for change is also limited.

Taken together, my chapter reinforces the argument put forward in the literature that the institutional investors are important players in shareholder engagement. Furthermore, my results strengthen the argument of McCahery, Sautner, and Starks (2013) and Dimson, Karakas, and Li (2013) who argue that institutional investors often use private dialogues as a means of engagement. The implications emerging from this chapter for institutional investors and also corporations are manifold. First, given my results I argue that private corporate engagements by institutional investors are an important and effective engagement tool that can promote changes in corporate behavior pertaining to ESG issues. My exemplary results for one particular UK-based institutional investor show that 
it is persistently engaging with the portfolio corporations and that these private dialogues also lead to changes at the target corporations. Second, the investors who outsource their engagement activities should be aware of the apparent home bias in shareholder engagement of the engagement agent. By delegating engagement activities to foreign asset managers, institutions should be aware of the fact that the engagement agent might also be prone to a home bias as documented in the investment literature (see, e.g., Coval and Moskowitz, 1999; Huberman, 2001). For engagement activities, this predilection means that they might be more likely to take place at corporations from the agent's home country because of its familiarity with local regulations and laws is the highest for those corporations.

Third, effectively, I study in this chapter the delegated engagement activities of several institutional investors. That is, I also shed light on the joint engagement activities of the institutional investors that is so far not yet documented in the corporate governance literature. By pooling the investment portfolios of several clients together, more pressure is created vis-à-vis the target corporations that makes them more likely to change according to the requests of the institutional shareholder. This is also reflected in the high success ratio of the engagement agent's objectives.

However, my conclusions of course only hold for this particular engagement agent and also most likely for other UK-based asset managers as well. This might be a direction for future research on shareholder engagement. Doing a similar study in a different jurisdiction, that is, investigating a US-based engagement agent might show how well my results relate to another financial market. Additional research on shareholder engagements through the study of multiple engagement agents might add to the discussion on how successful institutional shareholders can influence corporations. 


\section{Appendix 4.A - Full list of objective topics (with subcategories)}

\section{(1) Corporate Governance}

Audit and Control

Board Structure

Governance (Other)

Remuneration

Shareholder rights

(2) Sustainability Management and Reporting

Disclosure and reporting

Governance of Sustainability issues

Stakeholder Engagement

Sustainability (Other)

UNGC Compliance

\section{(3) Business Ethics}

Bribery and Corruption

Ethics (Other)

Political Influence

Responsible Marketing

Whistleblowing Systems

\section{(4) Human Rights}

Community relations

Human Rights (Other)

Privacy and Free Expression

Security

Weak Governance Zones

(5) Labor Standards

Diversity

Health and Safety

ILO Core Conventions

Labor Standards (Other)

Supply Chain Labor Standards

(6) Public Health

Access to Medicines

HIV/AIDs

Nutrition

Product Safety

Public Health (Other)

Tobacco

\section{(7) Environmental Management}

Environmental (Other)

Environmental Standards

Pollution Control

Product Opportunities

Supply Chain Environment

Supply Chain Environmental Standards

Waste and Recycling

\section{(8) Ecosystem Services}

Access to Land

Biodiversity Management

Ecosystem (Other)

Water

(9) Climate Change

Biofuels

Climate Change (Other)

Climate change strategy

Emissions Management and Reporting

Strategy

Environment (Old)

Biodiversity

Climate Change

Governance (Old)

Bribery and Corruption

Corporate Governance

Environmental Management Reporting

Transparency and Performance

Sector Specific (Old)

Banking

ICT

Pharmaceuticals

Social (Old)

HIV/AIDS

Human Rights

Labor Standards 


\section{Appendix 4.B - Variable definitions}

\begin{tabular}{|c|c|}
\hline Variable & Variable definition and calculation \\
\hline United States & $\begin{array}{l}\text { Indicator variable that equals one if corporation } i \text { originates from the } \\
\text { United States. }\end{array}$ \\
\hline Continental Europe & $\begin{array}{l}\text { Indicator variable that equals one if corporation } i \text { originates from Conti- } \\
\text { nental Europe. }\end{array}$ \\
\hline United Kingdom & $\begin{array}{l}\text { Indicator variable that equals one if corporation } i \text { originates from the } \\
\text { United Kingdom. }\end{array}$ \\
\hline Japan & Indicator variable that equals one if corporation $i$ originates from Japan. \\
\hline Civil-law country & $\begin{array}{l}\text { Indicator variable that equals one if corporation } i \text { originates from a civil- } \\
\text { law tradition country and zero otherwise. }\end{array}$ \\
\hline \# Objectives t-1 & $\begin{array}{l}\text { Number of objectives corporation } i \text { received in year } t-1 \text {. This variable } \\
\text { measures the overall number of objectives for the entire sample; for the } \\
\text { subsample analyses this variable measures the number of objectives in a } \\
\text { particular topic subsample. }\end{array}$ \\
\hline \# Milestones t-1 & $\begin{array}{l}\text { Number of milestones corporation } i \text { displays in year } t-1 \text {. This variable } \\
\text { measures the overall number of milestones for the entire sample; for the } \\
\text { subsample analyses this variable measures the number of milestones in a } \\
\text { particular topic subsample. }\end{array}$ \\
\hline Anti-director rights index & $\begin{array}{l}\text { Revised version of the anti-director rights index ranging from } 0 \text { to } 6 \text {. } \\
\text { Higher values indicate more investor protection. Source: Djankov et al. } \\
\text { (2008). }\end{array}$ \\
\hline Firm size & $\begin{array}{l}\text { Firm size of portfolio corporation } i \text { measured as the natural logarithm of } \\
\text { total assets (Worldscope item TotalAssets). }\end{array}$ \\
\hline Leverage & $\begin{array}{l}\text { Leverage ratio of investee corporation } i \text { calculated as total debt } \\
\text { (Worldscope item TotalDebt) over total assets (Worldscope item To- } \\
\text { talAssets). }\end{array}$ \\
\hline Dividend payer? & $\begin{array}{l}\text { Indicator variable that equals one if the portfolio corporation is paying out } \\
\text { dividends and zero otherwise. }\end{array}$ \\
\hline 1yr sales growth & $\begin{array}{l}\text { Past year's sales growth of portfolio corporation } i \text { (Worldscope item } \\
\text { Sales1YrGrowth). }\end{array}$ \\
\hline Closely held shares (\%) & $\begin{array}{l}\text { Percentage of shares held closely by insiders in a particular portfolio } \\
\text { corporation (Worldscope item CloselyHeldSharesPct). }\end{array}$ \\
\hline Tobin's Q & $\begin{array}{l}\text { Tobin's Q of corporation } i \text {. Calculated as in Ferreira and Matos (2008) as } \\
\text { total assets (Worldscope item TotalAssets) plus market value of equity } \\
\text { (Worldscope item CommonSharesOutstanding x Worldscope item Price- } \\
\text { Close) minus book value of equity (Worldscope item TotalCommonEqui- } \\
\text { ty) all over total assets (Worldscope item TotalAssets). }\end{array}$ \\
\hline
\end{tabular}




\section{CHAPTER 5 The Market for Public and Private Shareholder Engagement ${ }^{25}$}

In this chapter, I examine the evolution of the private and the public shareholder engagements at US corporations from 1999-2011. I also study the determinants of the occurrence and the success of both of these engagements. By means of a proprietary engagement database of a UK engagement agent and public data on shareholder proposals, I find that corporations are most likely to become an engagement target when they have been targeted with public and private shareholder engagements in the past. Furthermore, my results indicate that the existence of the private and the public engagements is a significant driver of a corporation's honoring likelihood. Corporations are significantly more likely to honor public shareholder engagements if they have a good reputation for honoring public engagements. Taken together, my findings have important implications for shareholders, managers, and researchers.

\footnotetext{
${ }^{25}$ This paper is based on Bauer, Bos, Derwall, and Viehs (2013). I thank Frank Moers and seminar participants at Maastricht University for helpful comments and suggestions. I am also grateful to Valentin Peter for excellent research assistance. Special thanks are directed to the Institutional Investor who provided the data on private engagements.
} 
CHAPTER 5 


\subsection{Introduction}

In this chapter, I study the evolution of the private and the public shareholder engagements and the determinants of their occurrences and their corresponding successes. I also investigate the effect of their presence on the probability that the corporations will honor these engagements. The ultimate aim of this empirical chapter is to provide the first indicative evidence on the dynamics of the shareholder engagement process and the interplay between the private and the public domains of engagement.

Corporations are often faced with activist shareholders who engage them to achieve changes in their corporate governance structures, as well as their corporate environmental and social policies. Institutional investors especially are often among those activist shareholders who closely monitor corporate actions. The corporate governance literature shows that the shareholder engagement often takes place through public means; for example, shareholder proposals (e.g., Gillan and Starks, 2000, 2007; Ertimur, Ferri, and Muslu, 2011; Chapters 2 and 3), just-vote-no campaigns (e.g., Del Guercio, Seery, and Woidtke, 2008), or class-action lawsuits (Romano, 1991). However, the more recent studies provide clear evidence that the shareholder engagement also takes place through private means such as private dialogues between the corporations and their institutional shareholders (see, e.g., McCahery, Sautner and Starks, 2013 for survey evidence). In contrast to a public engagement, a private shareholder engagement usually takes place bilaterally between the shareholder and the corporation. Importantly, this behind the scenes private engagement remains confidential and is not observable by other market participants. Empirically, Carleton, Nelson and Weisbach (1998) provide evidence that private dialogues are an effective mechanism in promoting change at the corporations. The fact that private shareholder engagement is growing in importance is also demonstrated by the increasing academic research that investigates this type of engagement (e.g., Chapter 4; Dimson, Karakas, and Li, 2013).

In contrast to these studies on shareholder engagement, which generally investigate either the public or the private shareholder engagements separately, I adopt a more holistic, but probably still incomplete, approach towards shareholder engagement by investigating both the public and the private engagement means at the same time.

To do so, I rely on data for both the private and the public shareholder engagements. My proxies for the public shareholder engagements are the shareholder proposals filed at the corporations. The data comes from the RiskMetrics' shareholder proposal database that comprises the information on all of the shareholder proposals at all of the S\&P1500 corporations and that I already used in Chapters 2 and 3. My private engagement data comes from a UK-based asset manager who provides engagement services to institutional clients (the engagement agent). The proprietary private engagement data comprises all of the private engagements undertaken with portfolio corporations. Similar versions of this data have already been used in other empirical studies on shareholder engagement (e.g., Chapter 4; Dimson, Karakas, and Li, 2013).

The goal of this chapter is threefold. First, I depict the evolution of both the private and the public shareholder engagements to see how they develop over time with respect 
to their occurrences, frequencies, and successes. Second, I provide evidence on the dynamics underlying the shareholder engagement process by studying the likelihood of being targeted by either or both of the two engagements. Therein, I emphasize the interaction and simultaneous occurrence of the private and the public engagements. Third, I show how the presence of both influences the honoring likelihood of the targeted corporations.

My results indicate that the shareholder engagement is a dynamic process and that it has both private and public facets. I find that an increasing number of corporations are being targeted by the private engagements. Likewise, the number of corporations receiving the public engagements also rises over my sample period. However, fewer corporations get the private engagements than the public engagements. My analyses indicate that the public engagements are generally more successful than the private engagements.

The empirical results of this chapter show that the presence of both the private and the public engagements in the previous year significantly increase the odds that the same corporation becomes an engagement target in the current year as well. This relation holds for any kind of engagement as well as for the simultaneous presence of both. I also show what effect the corporation's past honoring behavior has on the targeting probability in the current year. To do so, I construct engagement reputation variables that control for the extent to which corporations honored their past shareholder engagements (public and/or private). These variables are constructed by scaling the number of successful engagements by the number of engagements undertaken (either private or public engagements). For private engagements, the engagement reputation is calculated by dividing the number of successful private engagements by the number of privately undertaken engagements. Similarly, I calculate the public engagement reputation by dividing my proxy for successful public engagements - withdrawn shareholder proposals - by the number of filed shareholder proposals. My results show that a corporation's engagement reputation is negatively related to a corporation's targeting likelihood.

With respect to the success of the shareholder engagement, I find that the overall honoring probability is the highest for the corporations that are exposed to both the public and the private engagements in the same year in which the successful engagement occurred. Furthermore, my results disclose that the presence of the past public engagements significantly reduces the probability of success for the current public engagement. Additionally, I show that a corporation's public engagement reputation is positively related to the engagement success, that is, the corporations that honored the public engagements in the past are also more likely to display successful public engagements in the current year as well. Another important finding is that the concurrent public (private) engagements are not significantly related to the honoring likelihood of private (public) corporate social responsibility (CSR) engagements.

These findings have important implications for shareholders, corporations, and researchers. Even though my results are based on a very exemplary private engagement data set from a large institutional investor, I conclude that there are important interdependencies between the public and the private shareholder engagements. Institutional investors who want to engage with corporations should be aware of these effects when making their engagement decisions. Furthermore, I posit that the shareholder engage- 
ment should be investigated by taking all kinds of engagements into account. The literature studies the public and the private engagements separately most of the time, without taking into account that the engagement can also take place via different routes.

Of course, one has to be careful inferring generalizations from my conclusions. I combine a snapshot of private engagement data from just one institutional investor with data on a form of public engagement, shareholder proposals, that could essentially be filed by any shareholder. In other words, this private engagement data from a single institutional investor serves as a proxy for the private facet of the engagement process because other institutional investors presumably undertake similar endeavors to promote changes in investee corporations. Hence, I make the following two assumptions. First, I assume that the engagement activities of the large UK-based institutional investor at a particular corporation are a decent proxy for the engagement activities undertaken by all of the other institutional investors at the same corporation. Second, I presume that the engagements of the institutional investor on a particular topic like corporate environmental, social, or governance issues, approximate well the engagements undertaken by other institutional investors on the same topics at the same corporation. These two assumptions are of a realistic nature because the large institutional investors are highly connected to each other through important and huge networks, like the International Corporate Governance Network (ICGN) or the Council of Institutional Investors (CII). These investors exchange information on particularly important issues, and maybe even corporations. Hence, these networks could trigger implicit collaborative engagements at certain corporations on particular issues.

I contribute to the literature on shareholder engagement along the following lines. By investigating the private and the public shareholder engagements at the same time, I am the first to study the full shareholder engagement spectrum. I also contribute to the literature by studying the relatedness between the two engagement routes. Generally, the literature treats the private and the public engagements as two separate monitoring tools available to the shareholders. However, this view neglects the important interconnectedness of both engagements.

There is a plethora of literature that stresses the importance of public shareholder engagement as a corporate governance mechanism. Among the most commonly studied public engagement tools are the shareholder proposals (e.g., Gillan and Starks, 2000; Karpoff, Malatesta, and Walkling, 1996), class-action lawsuits (e.g., Romano, 1991), hedge fund engagement (e.g., Klein and Zur, 2009; Brav, Jiang, Partnoy, and Thomas, 2008; Brav, Jiang, and Kim, 2011), and the proxy voting by institutional investors (e.g., Del Guercio, Seery, and Woidtke, 2008; Yermack, 2010). Most of these studies investigate why the corporations become engaged with either of the tools mentioned, and how successful the shareholder engagement is. All of them have in common that they investigate the public engagements leaving aside the private engagements that continuously take place between the large institutional investors and the corporations.

A public shareholder engagement is fully observable and can create a lot of negative publicity against the corporations when shareholders raise critical issues such as executive compensation policies. However, today, most of the shareholder engagement is going on behind the scenes and is therefore not observable by the market. McCahery, 
Sautner, and Starks (2013) find that the institutional investors in the Netherlands and the United States use many different tools to exert pressure on corporations. These tools range from walking the Wall Street Walk, the shareholder proposals at annual general meetings (AGMs), discussions with management teams, or public criticism (McCahery, Sautner, and Starks, 2013). The authors' survey results show that the institutional investors are most of the time not only relying on one single engagement tool but use several public and private tools simultaneously. The private dialogues with management teams and boards especially are often used as private engagement tools.

Similarly, I argue in Chapter 4 that the institutional investors often privately engage with the corporations by means of their private dialogues, management meetings, telephone calls, or their emails. Only after these private negotiations fail or do not lead to satisfactory outcomes for the shareholders is the public engagement route undertaken as a last resort engagement tool (see, e.g., Chapter 3). Likewise, Dimson, Karakas, and Li (2013) investigate the private negotiations and rely on a similar though smaller data set from the same UK-based asset manager that I use in this chapter. Dimson, Karakas, and $\mathrm{Li}$ (2013) find that the private shareholder engagement is successful. The earlier findings of Carleton, Nelson, and Weisbach (1998) indicate that the private negotiations often take place between the institutional investors and the corporations. Carleton, Nelson, and Weisbach (1998) conclude that $70 \%$ of the issues that the TIAA-CREF raises at the investee corporations are settled before an actual vote at the AGM, which indicates a relatively high success rate for the private negotiations. Becht, Franks, Mayer, and Rossi (2009) also provide empirical evidence on private engagement activities of the UK Focus Fund. Similar to my approach, the authors also investigate the private engagements, which are presumed to be unobservable by other market participants. Overall, Becht, Franks, Mayer, and Rossi (2009) show that given its engagement in the corporations and the disclosure of the fund's stake acquisition in certain corporations, the fund significantly outperforms specific benchmarks. Hence, the authors conclude that the shareholder engagement is effectively creating shareholder value. However, the investment and engagement approaches of my asset manager differ from those observed by Becht, Franks, Mayer, and Rossi (2009) in the sense that my asset manager engages on behalf of several institutional clients. Furthermore, the authors only look at the private engagements and the market's reaction towards this type of engagement without taking into account the presence of any public shareholder engagement. I fill this gap and investigate both the private and the public facets of the shareholder engagements at the same time. I do so by studying the effects of the presence of both engagements, their interaction, as well as the corporation's engagement reputation on the likelihood that corporations will honor (i.e., settle the shareholders' concerns) the engagements of any kind.

Given the evidence on both the public and the private shareholder engagements, I conjecture that the private negotiations can be an effective corporate governance and engagement tool because the private dialogues always occur in the shadow of the potential public engagements, which could potentially create much more adverse effects for managers and corporations. 
The remainder of this chapter is structured as follows. Section 5.2 continues with a description of the data and their statistics. In Section 5.3, I present my empirical model and its results; and in Section 5.4, I conclude.

\subsection{Data and summary statistics}

\subsubsection{Data description}

My database on shareholder engagement consists of two parts. The first part of my engagement data consists of the information on all privately undertaken engagement activities of one large UK-based asset manager. This asset manager, as described in Chapter 4, can be considered as a conventional asset manager that also provides shareholder engagement services to institutional clients. The institutional clients can buy this engagement service and in doing so outsource all of their private engagement activities to this single asset manager. Therefore, on behalf of several other institutional investors, the asset manager is directly engaging with its own and its clients' portfolio corporations. Hence, the asset manager can be called an engagement agent.

The foundation for my private engagement data set are all of the US-listed corporations that are either part of the engagement agent's own portfolio or part of any of its clients' portfolios. For 1,894 corporations, I am able to retrieve the entire record of the private engagement data between 1999 and 2011. The engagement data for these corporations contain information on the number of contacts between the engagement agent and the portfolio corporations, the number of issues discussed with the portfolio corporations (objectives), and the number of successful engagements (milestones) for each of these sample corporations. The milestones are engagements that lead to change at the corporations due to the engagement agent's objectives. Hence, the milestones are my proxy for private engagement success. The milestones and the corresponding changes are directly observed and recorded by the asset manager and subsequently reported to its clients. Moreover, I know which topics were discussed in the private dialogues between the engagement agent and the target corporations. Specifically, I know if the engagement agent discussed corporate governance $(\mathrm{CG})$ or CSR issues with the portfolio corporations.

In the next step, I match all 1,894 private engagement corporations (which represent 24,622 firm-year observations) with data on the public shareholder engagements. These data come from RiskMetrics and comprises all of the shareholder proposals for all of the corporations in the S\&P1500. For every corporation, I calculate the number of proposals received in a given year, along with a breakdown into corporate governance and CSR proposals. Consistent with Chapter 3, I use the withdrawn shareholder proposals as my proxy for successful proposals. The withdrawn shareholder proposals represent a measure for success because they reflect the management implementing the shareholders' requests as specified in the proposal according to Landier and Nair (2009). More precisely, the withdrawn proposals occur through the sponsoring shareholder after the private 
negotiations with the management take place. During these negotiations, a satisfactory compromise is reached resulting in the withdrawal of the filed proposal. Hence, the withdrawn proposals are my measure for successful public shareholder engagements (see also Chapter 3).

In the data set construction, I also take into account any changes with regards to the index composition of the S\&P1500. That is, for every year between 1999 and 2011, I check whether a corporation becomes a member of the S\&P1500 or whether a particular corporation drops from the index. This accounting means that not all of the corporations in my final data set are an index member for the entire sample period. Overall, I have 12,549 firm-year observations that represent index member-years and are thus included in the final sample.

For the empirical analyses that follow, I construct two reputation measures based on the private and the public engagement information given by the corporations' past responses to shareholder engagements. The Reputation private is calculated by dividing the number of successful private engagements in $t-1$ by the number of total objectives raised at a particular corporation. Likewise, my public engagement reputation measure (reputation public) is constructed by taking the ratio of withdrawn shareholder proposals and the total number of filed shareholder proposals. That is, the lower values for each of the two reputation measures indicate a lower responsiveness of the corporations to any specific kind of engagement route, whereas a high value indicates a relatively high responsiveness to the shareholder engagement.

The public and private engagement data set is then matched with the financial and the accounting information. I retrieve the accounting information from Thomson Reuters' Worldscope, and this information comprises the data on a firm's cash position, size, leverage, profitability (ROE), percentage of closely held shares, and Tobin's Q. ${ }^{26}$ I control for these variables because the literature shows them to be influential in the context of shareholder engagement (see, e.g., Chapter 4). Especially a corporation's cash position is of huge interest to me, because the implementation of certain shareholder requests in the private and the public engagements is costly. The literature shows that less financially constrained corporations spend more on corporate goodness (Hong, Kubik, and Scheinkmann, 2012). I argue that this spending also holds true for the implementation of the CSR and corporate governance changes specified in the private and the public shareholder engagements. Hence, in the main model, I also control for the financial soundness of the sample corporations. Table 5.1 presents the summary statistics on the final data set.

Table 5.1 shows that the median sample corporation has total assets of US\$2,981 million, $21.2 \%$ debt in the capital structure, and a cash-to-assets ratio of $7.2 \%$. Furthermore, $10.6 \%$ of the median corporations' outstanding shares are held by corporate insiders and other pension funds. The median sample corporation displays a sales growth of $8.2 \%$ over the last year and has a Tobin's Q of 1.4. The engagement variables show that almost $29 \%$ of the sample corporations had at least one public engagement activity in the

\footnotetext{
${ }^{26}$ I calculate Tobin's Q as in Ferreira and Matos (2008).
} 
previous year (i.e., display at least one filed shareholder proposal). They also show that $12 \%$ of the sample corporations display at least one private engagement over the past year. The average public and private reputations of the sample corporations are $7.7 \%$ and $1.1 \%$ respectively. The evolution of the private and the public engagements is discussed in the following section.

Table 5.1: Sample summary statistics

This table presents the summary statistics on the variables used in the empirical analyses. I report the number of observations, mean values, median values and standard deviations for all variables. If not stated otherwise, the variables are measured at time $t_{0}$.

\begin{tabular}{lcccc}
\hline Variable & \#obs & Mean & Median & St. Dev. \\
\hline Firm Characteristics & & & & \\
Firm Size (Log Total Assets) & 12,501 & 8.159 & 8.000 & 1.580 \\
Leverage & 12,432 & 0.226 & 0.212 & 0.176 \\
Cash/Total Assets & 12,498 & 0.133 & 0.072 & 0.153 \\
\% Closely Held Shares & 11,662 & 0.135 & 0.106 & 0.146 \\
1yr Sales Growth & 11,839 & 0.110 & 0.082 & 0.221 \\
Dividend Payout Per Share & 12,479 & 0.266 & 0.113 & 0.621 \\
Tobin's Q & 12,368 & 1.818 & 1.386 & 1.389 \\
Engagement Variables & & & & \\
Public Engagement Dummy t-1 & 11,217 & 0.289 & 0 & 0.453 \\
Private Engagement Dummy t-1 & 11,839 & 0.120 & 0 & 0.324 \\
Public Engagement Reputation t-1 & 11,217 & 0.077 & 0 & 0.237 \\
Private Engagement Reputation t-1 & 11,839 & 0.011 & 0 & 0.102 \\
\hline
\end{tabular}

\subsubsection{How did public and private engagements evolve over time?}

In Table 5.2, I present the statistics on the evolution of the private and the public shareholder engagements. One clearly observes that the number of observations steadily increases over the sample period. The reason for this increase is that the engagement agent over time targets more and more corporations that are constituents of the S\&P1500. Overall, I have 12,549 firm-year observations in my final sample. The results also show that the number of observations with private engagements is in all years lower than the number of observations with public engagements. This result leads to the fact that overall, I have 1,630 observations with private engagements and 3,617 observations with public engagements in my sample. Interestingly, I find that 1,132 observations display both types of engagements and that a significant portion of the observations has neither of the engagements. These findings suggest that the number of corporations exposed to the private and public shareholder engagements is still relatively small: Out of 1,500 potential target corporations every year, just a small fraction receives either or both types of engagements. 
Table 5.2: Sample overview

This table presents a sample overview. The number of observations is equal to the number of corporations in the sample within a particular year. The third column displays the number of observations where private engagements took place, column four the number of observations where public engagements occurred, while column five presents the number of observations where both engagement types took place simultaneously. The last column specifies the number of observations where no engagement at all took place.

\begin{tabular}{lccccc}
\hline Year & Obs & $\begin{array}{c}\text { \# of Obs with Private \# of Obs with Public } \\
\text { Engagements }\end{array}$ & $\begin{array}{c}\text { \# of Obs with both } \\
\text { Engagements }\end{array}$ & $\begin{array}{c}\text { \# of Obs with no } \\
\text { Engagements }\end{array}$ \\
\hline 1999 & 710 & 7 & 149 & 7 & 561 \\
2000 & 771 & 17 & 191 & 14 & 577 \\
2001 & 807 & 49 & 202 & 42 & 598 \\
2002 & 837 & 60 & 224 & 45 & 598 \\
2003 & 859 & 92 & 262 & 72 & 577 \\
2004 & 888 & 295 & 315 & 202 & 480 \\
2005 & 933 & 136 & 284 & 104 & 617 \\
2006 & 976 & 130 & 301 & 87 & 632 \\
2007 & 1,056 & 142 & 329 & 102 & 687 \\
2008 & 1,123 & 109 & 346 & 89 & 757 \\
2009 & 1,160 & 140 & 360 & 101 & 761 \\
2010 & 1,191 & 227 & 307 & 115 & 772 \\
2011 & 1,238 & 226 & 347 & 152 & 817 \\
Grand total & 12,549 & 1,630 & 3,617 & 1,132 & 8,434 \\
\hline
\end{tabular}

In Table 5.3, I provide more detailed statistics on the number of engagements in every year and I split up the sample into two different engagement themes: Corporate governance and corporate social responsibility. Panel A of Table 5.3 presents the number of observations with private and public engagements in a particular year as well as the absolute number of the private and the public engagements corresponding to those observations. I find that the average number of the private engagements is quite volatile over time. Until 2005, the average count of the engagements increased to more than five per observation. Then, it decreased to 2.6 and then increased again until 2009 where the average number reached its all-time high of 7.2 engagements per private engagement observation. For the entire sample period, I find an average of 4.4 engagements per observation. Contrarily, this number is just 2.5 for the public engagements implying that the average number of shareholder proposals per corporation is much lower than the average number of private engagements. I detect a similar picture for every single year after 2001: The yearly average number of public engagements is lower than the average number of private engagements.

Panels B and C provide the same statistics for the two subsamples of the corporate governance and the CSR engagements. The results of Panel B suggest that on a yearly basis, much fewer corporations are targeted with private corporate governance engagements than with public governance engagements. This is not surprising because I study the engagement activities of just one institutional investor, whereas the public engagements can arise from the entire shareholder base. I also find that the variation in the number of corporations exposed to the private governance engagements is much wider 
than for the public engagements. Looking at the number of governance engagements per observations, I find that the average number of private corporate governance engagements is 2.6 whereas the average for the public engagements is 2.2. Hence, I conclude that the engagement agent targets on average fewer corporations but with higher intensity.

Table 5.3: Temporal evolution of private and public engagements

This table presents the average numbers of private and public engagements for the entire sample, and for the two subsamples of CSR and CG engagements.

\begin{tabular}{|c|c|c|c|c|c|c|}
\hline \multicolumn{7}{|c|}{ Panel A: Entire Sample } \\
\hline & $\begin{array}{l}\text { \# Obs w/ } \\
\text { Private En- } \\
\text { gagements }\end{array}$ & $\begin{array}{c}\text { \# Private } \\
\text { Engagements }\end{array}$ & $\begin{array}{c}\text { Private En- } \\
\text { gagements per } \\
\text { Obs }\end{array}$ & $\begin{array}{l}\text { \# Obs w/ Public } \\
\text { Engagements }\end{array}$ & $\begin{array}{l}\text { \# Public En- } \\
\text { gagements }\end{array}$ & $\begin{array}{c}\text { Public En- } \\
\text { gagements per } \\
\text { Obs }\end{array}$ \\
\hline 1999 & 7 & 7 & 1.0 & 149 & 341 & 2.3 \\
\hline 2000 & 17 & 37 & 2.2 & 191 & 495 & 2.6 \\
\hline 2001 & 49 & 119 & 2.4 & 202 & 491 & 2.4 \\
\hline 2002 & 60 & 265 & 4.4 & 224 & 546 & 2.4 \\
\hline 2003 & 92 & 511 & 5.6 & 262 & 763 & 2.9 \\
\hline 2004 & 295 & 773 & 2.6 & 315 & 823 & 2.6 \\
\hline 2005 & 136 & 639 & 4.7 & 284 & 809 & 2.8 \\
\hline 2006 & 130 & 515 & 4.0 & 301 & 776 & 2.6 \\
\hline 2007 & 142 & 441 & 3.1 & 329 & 882 & 2.7 \\
\hline 2008 & 109 & 507 & 4.7 & 346 & 919 & 2.7 \\
\hline 2009 & 140 & 1,002 & 7.2 & 360 & 897 & 2.5 \\
\hline 2010 & 227 & 1,237 & 5.4 & 307 & 728 & 2.4 \\
\hline 2011 & 226 & 1,089 & 4.8 & 347 & 721 & 2.1 \\
\hline Grand total & 1,630 & 7,142 & 4.4 & 3,617 & 9,191 & 2.5 \\
\hline \multicolumn{7}{|c|}{ Panel B: Corporate Governance (CG) Engagements } \\
\hline & $\begin{array}{c}\text { \# Obs w/ } \\
\text { Private CG } \\
\text { Engagements }\end{array}$ & $\begin{array}{l}\text { \# Private CG } \\
\text { Engagements }\end{array}$ & $\begin{array}{c}\text { Private CG } \\
\text { Engagements } \\
\text { per Obs }\end{array}$ & $\begin{array}{c}\text { \# Obs w/ Public } \\
\text { CG Engage- } \\
\text { ments }\end{array}$ & $\begin{array}{l}\text { \# Public CG } \\
\text { Engagements }\end{array}$ & $\begin{array}{c}\text { Public CG } \\
\text { Engagements } \\
\text { per Obs } \\
\end{array}$ \\
\hline 1999 & 0 & 0 & - & 116 & 219 & 1.9 \\
\hline 2000 & 11 & 19 & 1.7 & 139 & 328 & 2.4 \\
\hline 2001 & 14 & 22 & 1.6 & 145 & 312 & 2.2 \\
\hline 2002 & 42 & 139 & 3.3 & 165 & 338 & 2.0 \\
\hline 2003 & 74 & 236 & 3.2 & 218 & 542 & 2.5 \\
\hline 2004 & 284 & 478 & 1.7 & 271 & 601 & 2.2 \\
\hline 2005 & 129 & 362 & 2.8 & 224 & 553 & 2.5 \\
\hline 2006 & 118 & 325 & 2.8 & 242 & 515 & 2.1 \\
\hline 2007 & 94 & 245 & 2.6 & 260 & 609 & 2.3 \\
\hline 2008 & 95 & 251 & 2.6 & 279 & 600 & 2.2 \\
\hline 2009 & 95 & 382 & 4.0 & 285 & 624 & 2.2 \\
\hline 2010 & 188 & 462 & 2.5 & 236 & 510 & 2.2 \\
\hline 2011 & 98 & 344 & 3.5 & 280 & 516 & 1.8 \\
\hline Grand total & 1,242 & 3,265 & 2.6 & 2,860 & 6,267 & 2.2 \\
\hline
\end{tabular}


Table 5.3 continued

\begin{tabular}{lcccccc}
\hline \multicolumn{2}{c}{ Panel C: Corporate Social Responsibility (CSR) Engagements } & & & \\
\cline { 2 - 7 } & $\begin{array}{c}\text { \# Obs w/ } \\
\text { Private CSR } \\
\text { Engagements }\end{array}$ & $\begin{array}{c}\text { \# Private CSR } \\
\text { Engagements }\end{array}$ & $\begin{array}{c}\text { Private CSR } \\
\text { Engagements } \\
\text { per Obs }\end{array}$ & $\begin{array}{c}\text { \# Obs w/ Public } \\
\text { CSR Engage- } \\
\text { ments }\end{array}$ & $\begin{array}{c}\text { \# Public CSR } \\
\text { Engagements }\end{array}$ & $\begin{array}{c}\text { Public CSR } \\
\text { Engagements } \\
\text { per Obs }\end{array}$ \\
\hline 1999 & 7 & 7 & 1.0 & 74 & 113 & 1.5 \\
2000 & 10 & 18 & 1.8 & 101 & 148 & 1.5 \\
2001 & 43 & 97 & 2.3 & 109 & 170 & 1.6 \\
2002 & 38 & 126 & 3.3 & 127 & 205 & 1.6 \\
2003 & 38 & 192 & 5.1 & 122 & 205 & 1.7 \\
2004 & 61 & 210 & 3.4 & 138 & 217 & 1.6 \\
2005 & 61 & 238 & 3.9 & 145 & 249 & 1.7 \\
2006 & 61 & 190 & 3.1 & 148 & 257 & 1.7 \\
2007 & 93 & 196 & 2.1 & 156 & 239 & 1.5 \\
2008 & 61 & 256 & 4.2 & 175 & 288 & 1.6 \\
2009 & 121 & 620 & 5.1 & 173 & 251 & 1.5 \\
2010 & 205 & 775 & 3.8 & 144 & 208 & 1.4 \\
2011 & 199 & 745 & 3.7 & 146 & 196 & 1.3 \\
Grand total & 998 & 3,670 & 3.7 & 1,758 & 2,746 & 1.6 \\
\hline
\end{tabular}

A similar picture emerges for the CSR engagements (Panel $\mathrm{C}$ of Table 5.3). First, I note that the number of observations with CSR engagements in general is much smaller than for corporate governance engagements. This relation holds true for both the private and the public engagements. I observe that the private CSR engagements are very frequently conducted by the engagement agent in the latter three years of the sample period. The number of corporations with private CSR engagements from 2009 to 2011 is even higher than the number of corporations that are exposed to corporate governance engagements (Panel B). On average, I find 3.7 private CSR engagements per observation and 1.6 public CSR engagements. Again, this result shows that the engagement agent targets a selected group of corporations with high intensity engagements. Given that the engagement agent is exposed to resource constraints in terms of time and money, this result makes reasonable sense.

\subsubsection{How successful are the two engagement means?}

The most intriguing question of course is how successful the two different engagement mechanisms actually are. Table 5.4 provides the descriptive evidence on this question. Recall that a milestone is a private engagement success and that a withdrawn shareholder proposal represents a successful public engagement. To come up with a success measure, I calculate a success ratio by dividing the number of successful engagements by the number of the private and the public engagements. Panel A of Table 5.4 shows the success statistics for the entire sample of the engagements. For the entire sample, I find that with the exception of 2005 and 2008, the public engagements have higher success ratios. 
Consequently, the average success ratio is also much higher for the public engagements: $22.3 \%$ versus $11.5 \%$ successes for the private engagements. As was the case for the number of private engagements, I also find a very high volatility in the number of private engagement success, that is, milestones. In the first years of the sample period, the private engagements were not that successful. Then, the absolute number of milestones steadily increased until the all-time high in 2005 with 146 milestones and a success ratio of $22.8 \%$. Subsequently, the success ratio remains at reasonably high levels, ranging between 5.1 to $28.6 \%$ in 2008 . In contrast, the absolute number of public engagement successes and the corresponding success ratios exhibit a much less volatile evolution: The public success ratio varied between $13.5 \%$ in 1999 and $27.4 \%$ in 2007. Similar to the success of the private engagements, the year 2008 was also very successful for the public shareholder engagements: $26.1 \%$ successes. Generally, the public success ratios manifest similar levels to the ones reported in Chapter 3.

Table 5.4: Evolution of engagement success

This table presents statistics on the success of the engagements, split up into private and public engagements as well as CG and CSR engagements. I also present the success ratios for every engagement category that is the ratio of number of successful engagements to the number of engagements.

\begin{tabular}{lcccccc}
\hline $\begin{array}{l}\text { Panel A: Entire Sample } \\
\text { Year }\end{array}$ & $\begin{array}{c}\text { \# of Private } \\
\text { Engagements }\end{array}$ & $\begin{array}{c}\text { \# of Private } \\
\text { Successes }\end{array}$ & $\begin{array}{c}\text { Private Suc- } \\
\text { cess Ratio }\end{array}$ & $\begin{array}{c}\text { \# Public Engage- } \\
\text { ments }\end{array}$ & $\begin{array}{c}\text { \# of Public } \\
\text { Successes }\end{array}$ & $\begin{array}{c}\text { Public Success } \\
\text { Ratio }\end{array}$ \\
\hline 1999 & 7 & 0 & $0.0 \%$ & 341 & 46 & $13.5 \%$ \\
2000 & 37 & 0 & $0.0 \%$ & 495 & 119 & $24.0 \%$ \\
2001 & 119 & 4 & $3.4 \%$ & 491 & 84 & $17.1 \%$ \\
2002 & 265 & 33 & $12.5 \%$ & 546 & 120 & $22.0 \%$ \\
2003 & 511 & 39 & $7.6 \%$ & 763 & 159 & $20.8 \%$ \\
2004 & 773 & 58 & $7.5 \%$ & 823 & 179 & $21.7 \%$ \\
2005 & 639 & 146 & $22.8 \%$ & 809 & 183 & $22.6 \%$ \\
2006 & 515 & 78 & $15.1 \%$ & 776 & 153 & $19.7 \%$ \\
2007 & 441 & 93 & $21.1 \%$ & 882 & 242 & $27.4 \%$ \\
2008 & 507 & 145 & $28.6 \%$ & 919 & 240 & $26.1 \%$ \\
2009 & 1,002 & 85 & $8.5 \%$ & 897 & 226 & $25.2 \%$ \\
2010 & 1,237 & 63 & $5.1 \%$ & 728 & 144 & $19.8 \%$ \\
2011 & 1,089 & 78 & $7.2 \%$ & 721 & 155 & $21.5 \%$ \\
Total & 7,142 & 822 & $11.5 \%$ & 9,191 & 2,050 & $22.3 \%$ \\
\hline
\end{tabular}


Table 5.4 continued

\begin{tabular}{lcccccc}
\hline $\begin{array}{l}\text { Panel B: } \\
\text { Year }\end{array}$ & $\begin{array}{c}\text { \# of Private CG } \\
\text { Engagements }\end{array}$ & $\begin{array}{c}\text { \# of Private CG } \\
\text { Successes }\end{array}$ & $\begin{array}{c}\text { Private CG } \\
\text { Success Ratio }\end{array}$ & $\begin{array}{c}\text { \# Public CG } \\
\text { Engagements }\end{array}$ & $\begin{array}{c}\text { \# of Public CG } \\
\text { Successes }\end{array}$ & $\begin{array}{c}\text { Public CG } \\
\text { Success Ratio }\end{array}$ \\
\hline 1999 & 0 & 0 & - & 219 & 18 & $8.2 \%$ \\
2000 & 19 & 0 & $0.0 \%$ & 328 & 84 & $25.6 \%$ \\
2001 & 22 & 3 & $13.6 \%$ & 312 & 40 & $12.8 \%$ \\
2002 & 139 & 21 & $15.1 \%$ & 338 & 51 & $15.1 \%$ \\
2003 & 236 & 23 & $9.7 \%$ & 542 & 82 & $15.1 \%$ \\
2004 & 478 & 31 & $6.5 \%$ & 601 & 122 & $20.3 \%$ \\
2005 & 362 & 106 & $29.3 \%$ & 553 & 100 & $18.1 \%$ \\
2006 & 325 & 63 & $19.4 \%$ & 515 & 76 & $14.8 \%$ \\
2007 & 245 & 80 & $32.7 \%$ & 609 & 173 & $28.4 \%$ \\
2008 & 251 & 68 & $27.1 \%$ & 600 & 140 & $23.3 \%$ \\
2009 & 382 & 63 & $16.5 \%$ & 624 & 119 & $19.1 \%$ \\
2010 & 462 & 38 & $8.2 \%$ & 510 & 61 & $12.0 \%$ \\
2011 & 344 & 27 & $7.8 \%$ & 516 & 75 & $14.5 \%$ \\
Total & 3,265 & 523 & $16.0 \%$ & 6,267 & 1,141 & $18.2 \%$ \\
\hline
\end{tabular}

\begin{tabular}{lcccccc}
\hline $\begin{array}{l}\text { Panel C: } \\
\text { Year }\end{array}$ & $\begin{array}{c}\text { \# of Private CSR } \\
\text { Engagements }\end{array}$ & $\begin{array}{l}\text { \# of Private } \\
\text { CSR Successes }\end{array}$ & $\begin{array}{c}\text { Private CSR } \\
\text { Success Ratio }\end{array}$ & $\begin{array}{c}\text { \# Public CSR } \\
\text { Engagements }\end{array}$ & $\begin{array}{c}\text { \# of Public CSR } \\
\text { Successes }\end{array}$ & $\begin{array}{c}\text { Public CSR } \\
\text { Success Ratio }\end{array}$ \\
\hline 1999 & 7 & 0 & $0.0 \%$ & 113 & 26 & $23.0 \%$ \\
2000 & 18 & 0 & $0.0 \%$ & 148 & 33 & $22.3 \%$ \\
2001 & 97 & 1 & $1.0 \%$ & 170 & 44 & $25.9 \%$ \\
2002 & 126 & 12 & $9.5 \%$ & 205 & 69 & $33.7 \%$ \\
2003 & 192 & 10 & $5.2 \%$ & 205 & 75 & $36.6 \%$ \\
2004 & 210 & 18 & $8.6 \%$ & 217 & 57 & $26.3 \%$ \\
2005 & 238 & 30 & $12.6 \%$ & 249 & 80 & $32.1 \%$ \\
2006 & 190 & 15 & $7.9 \%$ & 257 & 77 & $30.0 \%$ \\
2007 & 196 & 13 & $6.6 \%$ & 239 & 68 & $28.5 \%$ \\
2008 & 256 & 77 & $30.1 \%$ & 288 & 96 & $33.3 \%$ \\
2009 & 620 & 22 & $3.5 \%$ & 251 & 102 & $40.6 \%$ \\
2010 & 775 & 25 & $3.2 \%$ & 208 & 82 & $39.4 \%$ \\
2011 & 745 & 51 & $6.8 \%$ & 196 & 76 & $38.8 \%$ \\
Total & 3,670 & 274 & $7.5 \%$ & 2,746 & 885 & $32.2 \%$ \\
\hline
\end{tabular}

I conclude from this descriptive evidence that the public shareholder engagement is more successful on average. However, one has to keep in mind several characteristics of the private engagement process that might explain its lower success ratio and also its higher intensity. First, I document the engagement activities of just one single institutional investor. On the other hand, the public engagements originate from the entire shareholder base. Second, the private engagements differ substantially in their nature from the 
public shareholder engagements. The engagement agent is continuously involved in discussions and meetings with the portfolio corporations, which my data reflects. All of the meetings and discussions are treated as a single engagement activity, even though the agent might be discussing a specific issue for the second or even the third time with the target corporation's management. Hence, the private engagement success ratio might be understated.

Panels B and C of Table 5.4 present the same statistics for corporate governance and the CSR engagements. Overall, I can conclude the same main message: The public corporate governance and CSR engagements are more successful than the private engagements. However, the difference in the success ratios is smaller for the corporate governance engagements (16.0\% vs. $18.2 \%)$ than for the CSR engagements (7.5\% vs. $32.2 \%)$. I also find substantial cross-sectional differences within the engagement types. My results indicate that the public CSR engagements are on average much more successful than the public corporate governance engagements $(32.2 \%$ vs. $18.2 \%)$. However, for private engagements, I find the opposite: the corporate governance engagements are much more successful than the CSR engagements ( $7.5 \%$ vs. $16 \%)$.

To sum up the descriptive evidence on the successes of the private and the public engagements, I find that both engagements are relatively successful. Even when I take into account all of the potential concerns about the private engagement data, I am still confident that an average success ratio of $11.5 \%$ for the private engagements still reflects very effective shareholder engagement by the engagement agent.

\subsection{Empirical analysis and results}

\subsubsection{Empirical setups}

My empirical analyses consist of two main parts. First, I study the determinants of the occurrences of shareholder engagements. And second, I investigate the likelihood that corporations will honor the shareholder engagements.

For the first part of the analyses, I regress several engagement variables that control for the presence of the private and the public engagements on four different dependent variables that are all indicator variables. These four dependent variables equal to one if (1) a corporation gets targeted with any kind of engagement, (2) a corporation gets targeted with a private engagement, (3) a corporation gets targeted with a public engagement, and (4) a corporation receives both types of engagements in a given year. I use logistic regression models to study the targeting likelihood:

Targeted yes or no $(0 \text { or } 1)_{i, t}$

$=\beta_{0}+\beta_{1}$ (Public engagement dummy $)_{i, t-1}+\beta_{2}$ (Reputation public $)_{i, t-1}$

$+\beta_{3}$ (Private engagement dummy $)_{i, t-1}+\beta_{4}(\text { Reputation private })_{i, t-1}$

$+\beta_{5}$ (Private $*$ Public engagement $)_{i, t-1}+$ Firm characteristics $_{i, t-1}$

+ Year and Industry Controls 
where the Public engagement dummy is an indicator variable that equals one if the corporation displays at least one shareholder proposal in $t-1$. Similarly, the Private engagement dummy equals one if the sample corporation displays at least one private engagement activity in year $t-1$. I also control for the effect of the two reputation measures on the honoring likelihood: Reputation private and Reputation public, defined as before. Additionally, I add an interaction term between the two kinds of engagement variables (Private*Public engagement) in the empirical model. Lastly, in all of my empirical models that follow, I control for the corporate characteristics and the industry and year effects.

The second part of my empirical analysis is concerned with the likelihood that corporations will honor their shareholder engagements. To investigate the determinants of a corporation's honoring decision, I again rely on a logistic regression model in which the dependent variable is one of seven different dependent variables on honoring (to be specified later on):

Honoring engagements yes or no $(0 \text { or } 1)_{i, t}$

$=\beta_{0}+\beta_{1}(\text { Public engagement dummy })_{i, t}+\beta_{2}$ (Public engagement dummy $)_{i, t-1}$

$+\beta_{3}$ (Reputation public $)_{i, t-1}$

$+\beta_{4}(\text { Private engagement dummy })_{i, t}+\beta_{5}$ (Private engagement dummy $)_{i, t-1}$

$+\beta_{6}(\text { Reputation private })_{i, t-1}+\beta_{7}(\text { Private } * \text { Public engagement })_{i, t-1}$

+ Firm characteristics ${ }_{i, t-1}+$ Year and Industry Controls

where the right-hand-side variables are defined as before. The dependent variable varies with respect to the underlying sample under investigation. I now continue with my empirical results.

\subsubsection{What determines the likelihood of becoming an engagement target?}

\subsubsection{What are the effects of past engagements and a corporation's engagement reputation?}

In this section, I exclusively focus on the first five independent variables of the empirical models. The first model of Table 5.5 presents the results for the corporations that become engaged with any kind of engagement type, that is, the dependent variable equals one as soon as a corporation gets either a public or a private engagement or even both in a particular year. From the corporation's perspective, my findings indicate that the presence of public engagements in the previous year increases the chances of having an engagement in the current year. I also find a positive and negative effect for the past year's private engagement activities. If a corporation gets private engagements in $t-1$, then the likelihood significantly increases that the same corporation also receives engagements in $\mathrm{t}_{0}$. The interaction term Private*Public engagement exhibits a significant and negative relation with the likelihood of becoming targeted.

Concerning my engagement reputation proxies, I find the following. A corporation's public engagement reputation significantly reduces the odds that the corporation be- 
comes targeted with any kind of shareholder engagement in the current year. This result implies that the corporations where shareholders have been successfully engaging on any kind of topic publicly, exhibit a lower likelihood of becoming an engagement target the next year. On the other hand, I find a negative but nonsignificant effect for the private engagement reputation.

I find very similar effects for the second model in which the dependent variable indicates if the corporation gets targeted with the private engagements or not. In other words, I am modeling the probability of becoming engaged with the private engagements. The effects of the public and the private engagements in $t-1$ are still positive and significant, even though the coefficient on the public engagement is smaller in its magnitude. The remaining engagement variables turn out to be nonsignificant for the targeting probability of the private engagements.

This conclusion changes in the third model in which the dependent variable now indicates if the corporation receives the public shareholder engagements in $t_{0}$. Again, I find positive and significant effects for the presence of the private and the public engagements in $t-1$. On top of that, my results emphasize the importance of the corporation's engagement reputation. Both the private and the public engagement reputation variables turn out to be negative and significant, which implies that the odds of becoming targeted with the shareholder proposals reduces when the corporation honors more private and public engagements in $t-1$. 


\section{CHAPTER 5}

Table 5.5: Determinants of targeting

This table presents the results of four different logistic regression models in which the dependent variable is different for each model. All right-hand-side variables are measured at t-1, whereas the dependent variables are measured at time $\mathrm{t}_{0}$. Robust $\mathrm{p}$-values are reported below the coefficients in parentheses, and $* * *, * *$, and * indicate statistical significance at the $1 \%, 5 \%$, and $10 \%$ levels.

\begin{tabular}{|c|c|c|c|c|}
\hline Dependent Variables: & $\begin{array}{c}\text { Model } 1 \\
\text { Targeted? }(0 / 1)\end{array}$ & $\begin{array}{c}\text { Model } 2 \\
\text { Private Engage- } \\
\text { ment? }\end{array}$ & $\begin{array}{c}\text { Model } 3 \\
\text { Public Engage- } \\
\text { ment? }\end{array}$ & $\begin{array}{c}\text { Model } 4 \\
\text { Both Engagement } \\
\text { Types? }\end{array}$ \\
\hline \multirow[t]{2}{*}{ Public Engagement t-1 } & $2.323 * * *$ & $0.492 * * *$ & $2.542 * * *$ & $1.541 * * *$ \\
\hline & $(0.000)$ & $(0.000)$ & $(0.000)$ & $(0.000)$ \\
\hline \multirow[t]{2}{*}{ Reputation Public t-1 } & $-1.575 * * *$ & -0.137 & $-1.676^{* * *}$ & $-0.601 * * *$ \\
\hline & $(0.000)$ & $(0.310)$ & $(0.000)$ & $(0.000)$ \\
\hline \multirow[t]{2}{*}{ Private Engagement t-1 } & $0.839 * * *$ & $0.924 * * *$ & $0.568 * * *$ & $0.965^{* * *}$ \\
\hline & $(0.000)$ & $(0.000)$ & $(0.000)$ & $(0.000)$ \\
\hline \multirow[t]{2}{*}{ Reputation Private t-1 } & -0.386 & 0.287 & $-0.453 * *$ & 0.264 \\
\hline & $(0.151)$ & $(0.225)$ & $(0.034)$ & $(0.214)$ \\
\hline \multirow[t]{2}{*}{ Private*Public Engagement t-1 } & $-0.367 * *$ & 0.025 & $-0.406^{* *}$ & -0.156 \\
\hline & $(0.040)$ & $(0.889)$ & $(0.016)$ & $(0.480)$ \\
\hline \multirow[t]{2}{*}{ Firm Size } & $0.909 * * *$ & $0.989 * * *$ & $0.797 * * *$ & $1.099 * * *$ \\
\hline & $(0.000)$ & $(0.000)$ & $(0.000)$ & $(0.000)$ \\
\hline \multirow[t]{2}{*}{ Leverage } & 0.240 & -0.355 & 0.280 & $-0.528 *$ \\
\hline & $(0.202)$ & $(0.154)$ & $(0.145)$ & $(0.092)$ \\
\hline \multirow[t]{2}{*}{ Cash } & $0.883 * * *$ & $1.256^{* * *}$ & $0.624 * *$ & $1.339 * * *$ \\
\hline & $(0.000)$ & $(0.000)$ & $(0.013)$ & $(0.000)$ \\
\hline \multirow[t]{2}{*}{ \% Closely Held Shares } & -0.321 & -0.307 & $-0.491 * *$ & $-0.789 * *$ \\
\hline & $(0.142)$ & $(0.273)$ & $(0.031)$ & $(0.028)$ \\
\hline \multirow[t]{2}{*}{ 1yr Sales Growth } & $-0.534 * * *$ & -0.012 & $-0.475 * * *$ & 0.219 \\
\hline & $(0.000)$ & $(0.945)$ & $(0.001)$ & $(0.313)$ \\
\hline \multirow[t]{2}{*}{ Dividends per Share } & $0.153 * * *$ & 0.067 & $0.181 * * *$ & 0.111 \\
\hline & $(0.001)$ & $(0.289)$ & $(0.000)$ & $(0.149)$ \\
\hline \multirow[t]{2}{*}{ Tobin's Q } & $0.137 * * *$ & $0.213 * * *$ & $0.087 * * *$ & $0.176^{* * *}$ \\
\hline & $(0.000)$ & $(0.000)$ & $(0.000)$ & $(0.000)$ \\
\hline \multirow[t]{2}{*}{ Constant } & $-8.945 * * *$ & $-10.737 * * *$ & $-8.324 * * *$ & $-12.706^{* * *}$ \\
\hline & $(0.000)$ & $(0.000)$ & $(0.000)$ & $(0.000)$ \\
\hline Industry Controls & yes & Yes & yes & yes \\
\hline Time Effects? & yes & Yes & yes & yes \\
\hline Number of Observations & 10,801 & 10,801 & 10,801 & 10,801 \\
\hline Pseudo R-Squared & 0.404 & 0.378 & 0.402 & 0.463 \\
\hline
\end{tabular}

Lastly, I model the probability that the corporation is exposed to both the private and the public engagements at the same time. The results are very similar to the first model of 
Table 5.5, with the exception that the interaction term turns out to no longer be significant.

Overall, I can conclude that a corporation's exposure to the private and the public engagements in the last year significantly increases the chances that the same corporation receives any kind of engagement in the next year as well. For the public engagements to take place, it is also important that a corporation does not display a lot of successful private engagements in the previous year. Importantly, for the private engagements to take place, the corporation's private engagement reputation does not influence the targeting likelihood. My findings also show that the corporations are much less likely to become engagement targets again when they have acquired high public engagement reputations.

\subsubsection{What are the effects of firm characteristics?}

In this section, I elaborate on the effects that different firm characteristics have on the targeting likelihood. Basically, I find very consistent effects for all four models under investigation. My results suggest that a firm's size, cash position and Tobin's Q significantly increases the odds that it becomes engaged with any kind or even both kinds of engagements. This increase implies that shareholders target financially sound and large corporations more often because they expect that these corporations can afford the implementation of certain shareholder requests. I also find that poorly performing corporations and the corporations with more closely held shares are less likely to be targeted with the public shareholder engagements. It is important to note that several corporate characteristics are important for the presence of the public shareholder engagements, but not for the private engagements (e.g., closely held shares, past performance, and dividends per share).

\subsubsection{What are the economic effects concerning the targeting likelihood?}

To illustrate the effects of the engagement means on the targeting probability, I now provide the economic magnitudes of these effects. I explain here in detail one example of my calculations and provide one summary table with the results for all four models in Table 5.5. I have to stress that these results are all based on hypothetical types of firms. That is, all results in italics are in fact hypothetical results because firms cannot have a nonzero engagement reputation when there in fact were no engagements in $t-1$.

Based on the assumption that an average sample corporation just displays public engagements in $t-1$ and has a public and a private engagement reputation of zero, then the likelihood that this particular corporation becomes targeted with any kind of engagement is equal to $69.5 \%$. In contrast, if the same corporation exhibits private engagements instead of public engagements in $t-1$, then the targeting likelihood is equal to $34.1 \%$. Hence, the effect of being exposed to the public engagements on the targeting likelihood is much stronger than the effect of the private engagements. This finding is not surprising because by construction my proxy for the public shareholder engagement (that is, shareholder proposals) occurs more often and also because it arises out of the entire shareholder base. 
I now investigate the same average corporation but now I assume that the corporation was exposed to both the public and the private engagements in $t-1$. The reputation measures are still assumed to be equal to zero. Thus, the targeting likelihood becomes $78.5 \%$. Now, I also take into account the different engagement reputation levels. I assume that the same average corporation with both the private and the public engagements in $t-1$, and that this corporation has a public and a private engagement reputation of one. In other words, I study a corporation that was exposed to both engagements in the past year and honored all of its shareholder engagements as well. Thus, the probability that the same corporation becomes an engagement target in the current year is equal to $34 \%$. Hence, because of their negative effects, the inclusion of the interaction term between private and public engagements, and the two reputation measures cancel out the effect of the public engagements in $t-1$. A summary with all of the targeting probabilities for all of the four models in Table 5.5 is provided in Table 5.6.

Panel A of Table 5.6 presents the predicted probabilities for the targeting likelihood concerning any kind of engagement. It summarizes the example calculations of the section before. One clearly sees that those corporations exhibit the highest predicted targeting likelihood which are exposed to the public engagements in $t-1$. If the corporation's public and private engagement reputation is also very low, and it also displays the private engagements in $t-1$; then the targeting likelihood becomes the highest. This is very useful information for corporations who want to prepare for potential shareholder engagements. Panels B-D of Table 5.6 present the predicted targeting likelihoods for the three remaining models in Table 5.5. The overall picture that emerges is that a necessary pre-condition for a very high likelihood of becoming targeted with either private, public, or even both engagements is that the corporation must display the public engagements in $t-1$.

I conclude from this section that the likelihood of becoming targeted with any kind of shareholder engagement is highest for the corporations that are exposed to both mechanisms in the past but that have low engagement reputations in the first place. 
Table 5.6: Predicted targeting probabilities

This table presents the predicted targeting probabilities for the four legit models presented in Table 5.5. Panel A calculates the probabilities for the first model, Panel B for the second, and so forth. Note that the probabilities in italics are just the hypothetical honoring probabilities for firms that might not exist in reality.

\section{Panel A: Targeting Likelihood for any Kind of Engagement}

\begin{tabular}{|c|c|c|c|c|c|c|}
\hline & & & \multicolumn{4}{|c|}{ Public Engagement t-1 } \\
\hline & & & \multicolumn{2}{|c|}{ Yes } & \multicolumn{2}{|c|}{ No } \\
\hline & & & $\begin{array}{c}\text { Public Eng. } \\
\text { Reputation }=1\end{array}$ & $\begin{array}{c}\text { Public Eng. } \\
\text { Reputation }=0\end{array}$ & $\begin{array}{c}\text { Public Eng. } \\
\text { Reputation }=1\end{array}$ & $\begin{array}{c}\text { Public Eng. } \\
\text { Reputation }=0\end{array}$ \\
\hline \multirow{4}{*}{ 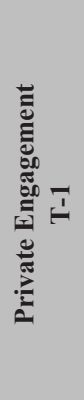 } & \multirow{2}{*}{$\stackrel{\theta}{\nu}$} & $\begin{array}{l}\text { Private Eng. } \\
\text { Reputation = } 1\end{array}$ & $34.0 \%$ & $71.3 \%$ & $6.8 \%$ & $26.0 \%$ \\
\hline & & $\begin{array}{l}\text { Private Eng. } \\
\text { Reputation }=0\end{array}$ & $43.1 \%$ & $78.5 \%$ & $9.7 \%$ & $34.1 \%$ \\
\hline & \multirow{2}{*}{$\stackrel{\ominus}{z}$} & $\begin{array}{c}\text { Private Eng. } \\
\text { Reputation }=1\end{array}$ & $24.3 \%$ & $60.8 \%$ & $3.1 \%$ & $13.2 \%$ \\
\hline & & $\begin{array}{l}\text { Private Eng. } \\
\text { Reputation }=0\end{array}$ & $32.1 \%$ & $69.5 \%$ & $4.4 \%$ & $18.3 \%$ \\
\hline
\end{tabular}

Panel B: Targeting Likelihood for Private Engagement

\begin{tabular}{|c|c|c|c|c|c|c|}
\hline & & & \multicolumn{4}{|c|}{ Public Engagement t-1 } \\
\hline & & & \multicolumn{2}{|c|}{ Yes } & \multicolumn{2}{|c|}{ No } \\
\hline & & & $\begin{array}{c}\text { Public Eng. } \\
\text { Reputation }=1\end{array}$ & $\begin{array}{c}\text { Public Eng. } \\
\text { Reputation }=0\end{array}$ & $\begin{array}{c}\text { Public Eng. } \\
\text { Reputation }=1\end{array}$ & $\begin{array}{c}\text { Public Eng. } \\
\text { Reputation }=0\end{array}$ \\
\hline \multirow{4}{*}{ 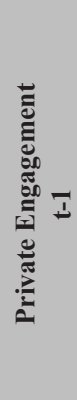 } & \multirow{2}{*}{$\stackrel{\theta}{\nu}$} & $\begin{array}{l}\text { Private Eng. } \\
\text { reputation = } 1\end{array}$ & $18.2 \%$ & $20.3 \%$ & $11.7 \%$ & $13.2 \%$ \\
\hline & & $\begin{array}{l}\text { Private Eng. } \\
\text { reputation }=0\end{array}$ & $14.3 \%$ & $16.1 \%$ & $9.0 \%$ & $10.2 \%$ \\
\hline & \multirow{2}{*}{$\stackrel{\circ}{z}$} & $\begin{array}{l}\text { Private Eng. } \\
\text { reputation }=1\end{array}$ & $7.9 \%$ & $9.0 \%$ & $5.0 \%$ & $5.7 \%$ \\
\hline & & $\begin{array}{l}\text { Private Eng. } \\
\text { reputation }=0\end{array}$ & $6.1 \%$ & $6.9 \%$ & $3.8 \%$ & $4.3 \%$ \\
\hline
\end{tabular}


CHAPTER 5

Table 5.6 continued

Panel C: Targeting Likelihood for Public Engagement

Public Engagement t-1

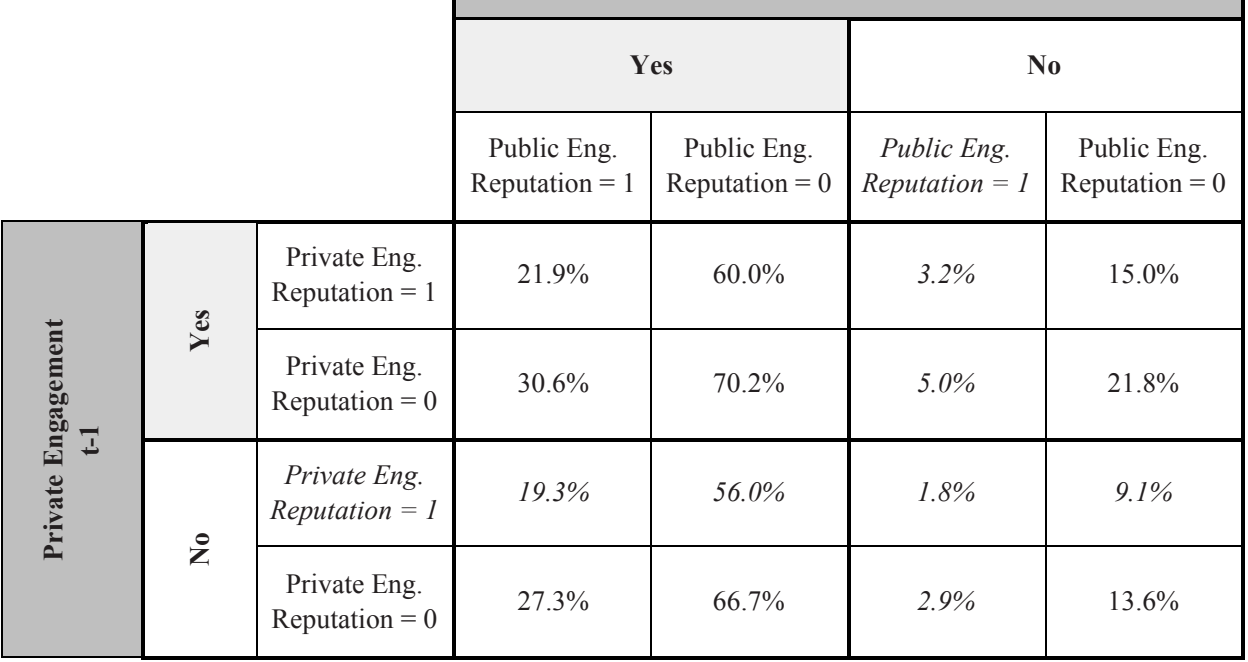

Panel D: Targeting likelihood for both Engagement Types

Public engagement t-1

\begin{tabular}{|c|c|c|c|c|c|c|}
\hline & & & \multicolumn{4}{|c|}{ Public engagement t-1 } \\
\hline & & & \multicolumn{2}{|c|}{ yes } & \multicolumn{2}{|c|}{ no } \\
\hline & & & $\begin{array}{l}\text { Public Eng. } \\
\text { reputation = } 1\end{array}$ & $\begin{array}{l}\text { Public Eng. } \\
\text { reputation }=0\end{array}$ & $\begin{array}{l}\text { Public Eng. } \\
\text { reputation }=1\end{array}$ & $\begin{array}{l}\text { Public Eng. } \\
\text { reputation }=0\end{array}$ \\
\hline \multirow{4}{*}{ 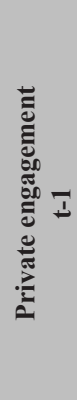 } & \multirow{2}{*}{$\stackrel{y}{\partial}$} & $\begin{array}{l}\text { Private Eng. } \\
\text { reputation = } 1\end{array}$ & $8.1 \%$ & $13.8 \%$ & $2.2 \%$ & $3.9 \%$ \\
\hline & & $\begin{array}{l}\text { Private Eng. } \\
\text { reputation }=0\end{array}$ & $6.3 \%$ & $11.0 \%$ & $1.7 \%$ & $3.0 \%$ \\
\hline & \multirow{2}{*}{$\stackrel{\varrho}{\varrho}$} & $\begin{array}{l}\text { Private Eng. } \\
\text { reputation }=1\end{array}$ & $3.8 \%$ & $6.7 \%$ & $0.8 \%$ & $1.5 \%$ \\
\hline & & $\begin{array}{l}\text { Private Eng. } \\
\text { reputation }=0\end{array}$ & $2.9 \%$ & $5.2 \%$ & $0.6 \%$ & $1.2 \%$ \\
\hline
\end{tabular}


Table 5.7: Determinants of targeting (sub-topics)

This table presents the results of four different logistic regression models in which the dependent variable is different for each model. The dependent variables are indicator variables that equal one if the corresponding engagement type is present and zero otherwise. All right-hand-side variables are measured at $t-1$, whereas the dependent variables are measured at time $t_{0}$. Robust $\mathrm{p}$-values are reported below the coefficients in parentheses, and $* * *, * *$, and $*$ indicate statistical significance at the $1 \%, 5 \%$, and $10 \%$ levels.

\begin{tabular}{|c|c|c|c|c|}
\hline \multirow[b]{2}{*}{ Dependent Variables: } & Model 1 & Model 2 & Model 3 & Model 4 \\
\hline & $\begin{array}{c}\text { Private CG } \\
\text { Engagement? }\end{array}$ & $\begin{array}{c}\text { Public CG En- } \\
\text { gagement? }\end{array}$ & $\begin{array}{c}\text { Private CSR } \\
\text { Engagement? }\end{array}$ & $\begin{array}{c}\text { Public CSR } \\
\text { Engagement? }\end{array}$ \\
\hline \multirow[t]{2}{*}{ Public Engagement t-1 } & $0.515 * * *$ & $2.259 * * *$ & $0.401 * * *$ & $1.653 * * *$ \\
\hline & $(0.000)$ & $(0.000)$ & $(0.002)$ & $(0.000)$ \\
\hline \multirow[t]{2}{*}{ Reputation Public t-1 } & -0.188 & $-1.383 * * *$ & $-0.284^{*}$ & $-0.816^{* * *}$ \\
\hline & $(0.196)$ & $(0.000)$ & $(0.067)$ & $(0.000)$ \\
\hline \multirow[t]{2}{*}{ Private Engagement t-1 } & $1.023 * * *$ & $0.523 * * *$ & $0.790 * * *$ & $0.716^{* * *}$ \\
\hline & $(0.000)$ & $(0.000)$ & $(0.000)$ & $(0.000)$ \\
\hline \multirow[t]{2}{*}{ Reputation Private t-1 } & 0.334 & -0.072 & -0.105 & $-0.415 * *$ \\
\hline & $(0.129)$ & $(0.742)$ & $(0.661)$ & $(0.037)$ \\
\hline \multirow[t]{2}{*}{ Private* PublicEngagement t-1 } & -0.105 & -0.231 & 0.303 & $-0.419 * *$ \\
\hline & $(0.574)$ & $(0.169)$ & $(0.157)$ & $(0.020)$ \\
\hline \multirow[t]{2}{*}{ Firm Size } & $0.814 * * *$ & $0.776^{* * *}$ & $1.057 * * *$ & $0.657 * * *$ \\
\hline & $(0.000)$ & $(0.000)$ & $(0.000)$ & $(0.000)$ \\
\hline \multirow[t]{2}{*}{ Leverage } & 0.125 & $0.683^{* * *}$ & -0.051 & -0.301 \\
\hline & $(0.625)$ & $(0.001)$ & $(0.868)$ & $(0.183)$ \\
\hline \multirow[t]{2}{*}{ Cash } & $1.330 * * *$ & $0.873^{* * *}$ & $1.282 * * *$ & 0.350 \\
\hline & $(0.000)$ & $(0.001)$ & $(0.000)$ & $(0.261)$ \\
\hline \multirow[t]{2}{*}{ \% Closely Held Shares } & -0.322 & -0.235 & 0.133 & $-0.472 *$ \\
\hline & $(0.277)$ & $(0.326)$ & $(0.704)$ & $(0.066)$ \\
\hline \multirow[t]{2}{*}{ 1yr Sales Growth } & 0.158 & $-0.685^{* * *}$ & 0.119 & $-0.290^{*}$ \\
\hline & $(0.400)$ & $(0.000)$ & $(0.579)$ & $(0.083)$ \\
\hline \multirow[t]{2}{*}{ Dividends Per Share } & 0.038 & $0.136^{* * *}$ & $0.131^{*}$ & $0.181 * * *$ \\
\hline & $(0.572)$ & $(0.006)$ & $(0.073)$ & $(0.001)$ \\
\hline \multirow[t]{2}{*}{ Tobin's Q } & $0.158 * * *$ & 0.013 & $0.226^{* * *}$ & $0.105 * * *$ \\
\hline & $(0.000)$ & $(0.632)$ & $(0.000)$ & $(0.000)$ \\
\hline \multirow[t]{2}{*}{ Constant } & $-10.425 * * *$ & $-9.141 * * *$ & $-11.945 * * *$ & $-7.867 * * *$ \\
\hline & $(0.000)$ & $(0.000)$ & $(0.000)$ & $(0.000)$ \\
\hline Industry Controls & yes & yes & yes & yes \\
\hline Time Effects & yes & yes & yes & yes \\
\hline Number of Observations & 10,801 & 10,801 & 10,801 & 10,801 \\
\hline Pseudo R-Squared & 0.346 & 0.391 & 0.395 & 0.300 \\
\hline
\end{tabular}


In order to investigate how the determinants of targeting differ across engagement topics, I conduct the same analysis as before for the corporate governance and the CSR engagements. This is done in Table 5.7 in which it becomes apparent that a corporation's exposure to these engagements is driven by the same factors as the entire sample. In particular, I stress the importance of a corporation's private engagement reputation for the public CSR engagements (Model 4). Highly reputable corporations with respect to private engagements drive down the likelihood that the corporations become targeted with the public CSR topics.

\subsubsection{How do private and public engagements relate to the honoring likelihood?}

In this section, I investigate the effect of the private and the public engagements on the honoring likelihood. Table 5.8 presents the outcomes of the empirical models outlined in Section 5.3.1. All of the models of this table control for the corporate characteristics, and the year and industry effects. I focus on the effects of the engagement control variables on the honoring likelihood. Model 1 shows the results for the overall honoring likelihood, irrespective of the engagement type. Apparently, a corporation's honoring decision is substantially influenced by the presence of concurrent and past engagements, both privately and publicly. The concurrent presence of at least one public and one private engagement significantly increases the odds that a corporation will honor any engagements. To illustrate, an average corporation without any engagement reputation and no engagements in $t-1$ but with just public engagements in $\mathrm{t}_{0}$ exhibits a honoring likelihood of $46.7 \%$. The same corporation with both engagement types in $t_{0}$ displays a honoring likelihood of $57.8 \%$. Hence, the simultaneous presence of both the public and the private shareholder engagements increases the odds that the corporation honors at least one engagement by more than ten percentage points - all else being equal. 


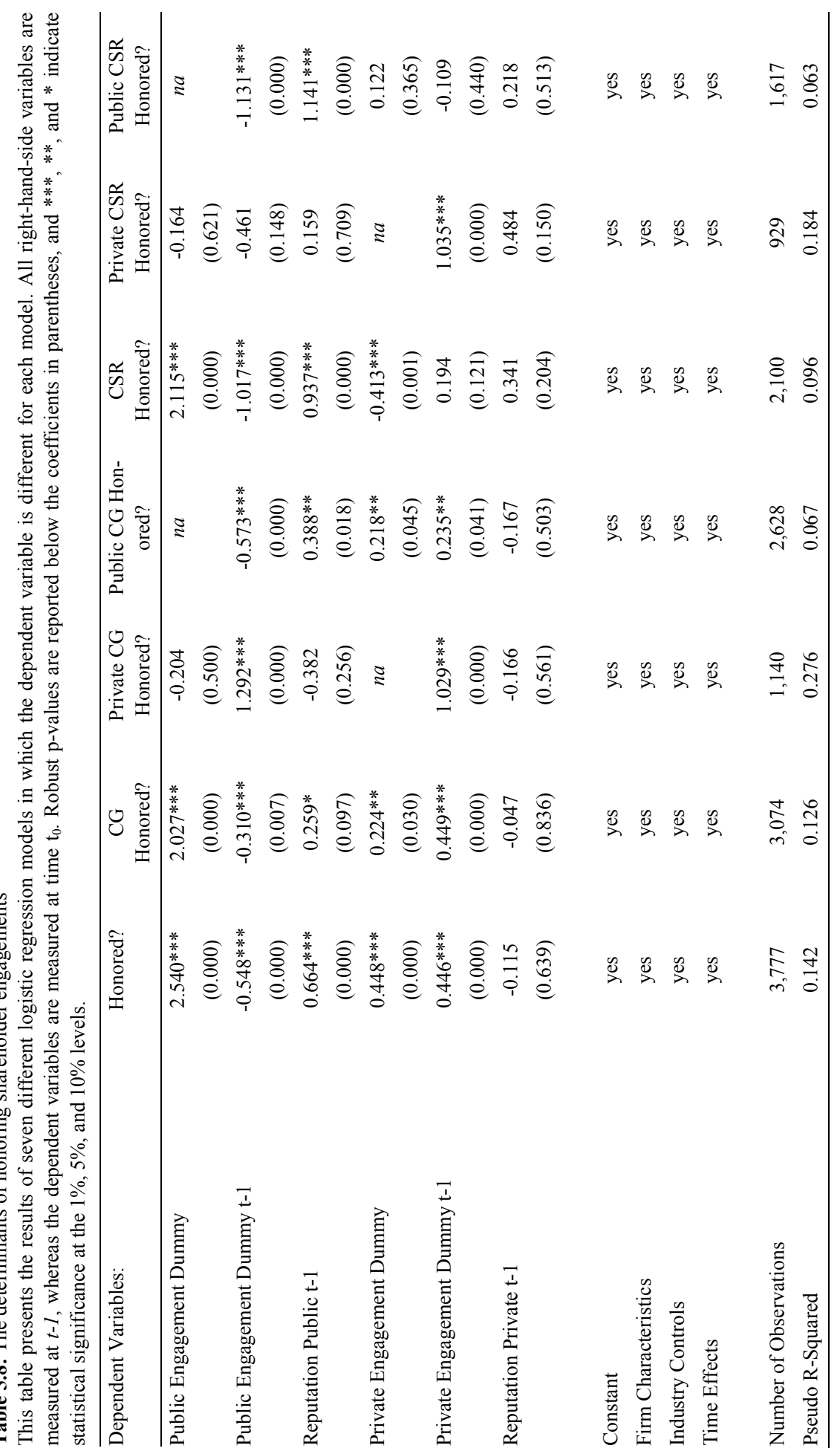


A corporation's engagement history also matters for its current honoring decisions. I find that the past public and private engagements at a corporation also significantly affect the corporation's current honoring decision. More specifically, I find that when the corporation was exposed to public engagements in $t-1$, the chances that it will honor an engagement in $t_{0}$ decreases significantly. Contrarily, the corporation's past private engagements significantly increase the likelihood that the target corporation will honor an engagement. To illustrate these effects, consider the following example. Recall that an average corporation - without any engagement reputation - with just public engagements in $t_{0}$ has a honoring likelihood of $46.7 \%$. When I take this exemplary corporation and assume that it also displays public engagements in $t-1$, I find a honoring likelihood of $33.6 \%$. I conclude from this result that these kinds of corporations are less likely to honor engagements when they are targeted repeatedly with the public engagements. A corporation with both engagement types in $\mathrm{t}_{0}$ but only private engagements in $t-1$ exhibits a likelihood of $68.2 \%$. Comparatively, a corporation with both types of engagements in $t_{0}$ and $t-1$ displays a honoring probability of $55.3 \%$. Hence, I conclude that the engagement agent should especially target those corporations at which no public engagement has taken place in $t-1$ but has in $\mathrm{t}_{0}$ and at which the private engagements were conducted in $t$ 1 , because they increase the chances that the target corporation will honor at least one engagement activity of any kind.

Concerning the effects of a corporation's engagement reputation, I find that highly reputable corporations with respect to the public engagements have a much higher honoring probability than the corporations with a low public engagement reputation. Further, I conclude from my findings that a corporation's private engagement successes do not substantially affect a corporation's current honoring likelihood.

An overview of the honoring probabilities arising out of the first empirical model in Table 5.8 can be found in Table 5.9. 


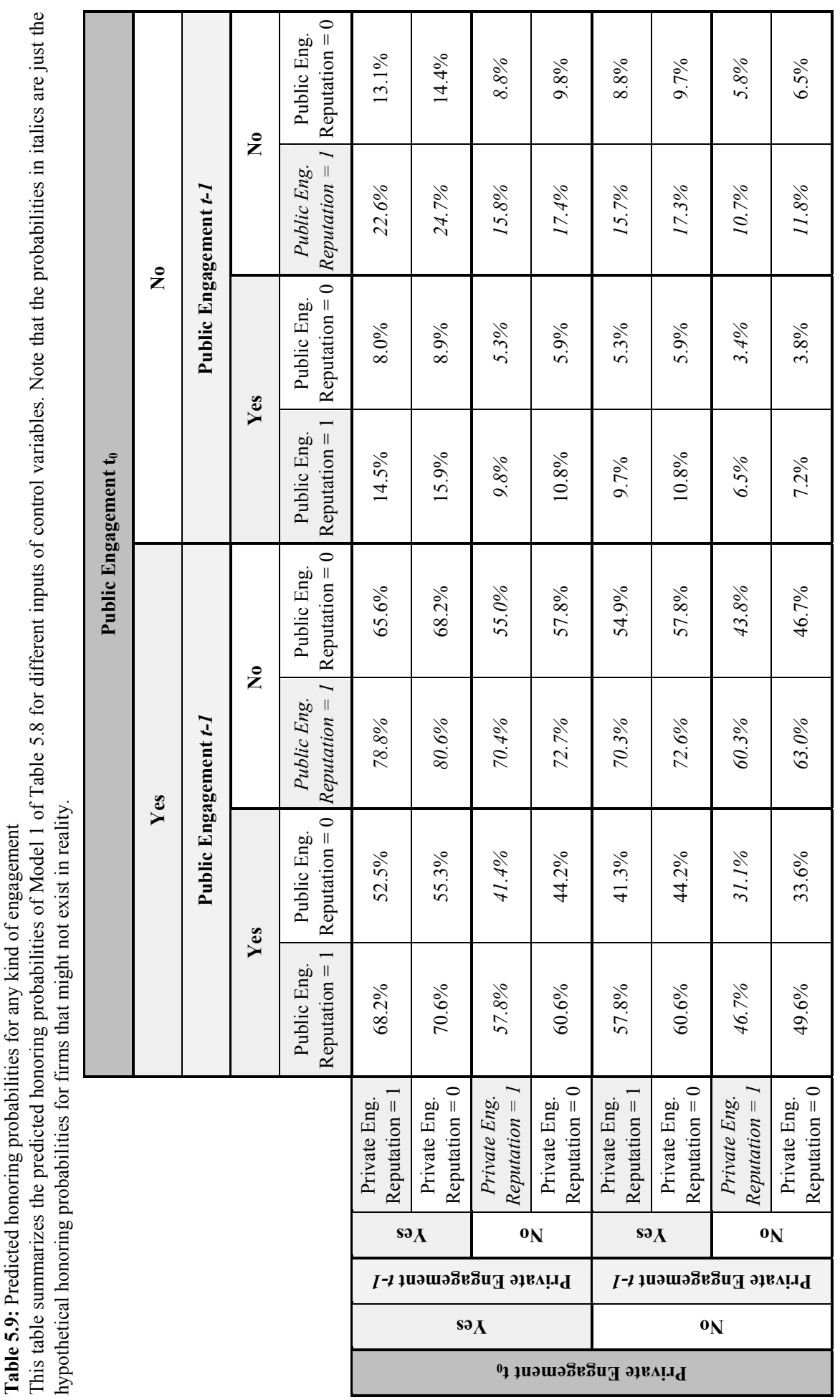


These probabilities are based on all of the combinations of my engagement control variables, assuming the two most extreme values for the engagement reputation of zero (no honored engagements in the past) and one (all received engagements are honored). It is important to realize that these results are all based on hypothetical types of firms. In particular, the numbers in Table 5.9 which are displayed in italics are the results for types of firms which can just exist if some engagement activities earlier than in $t-1$ have been honored to the fullest extent possible. Otherwise, the engagement reputation cannot be equal to one, as there were no private or public engagements in $t-1$. This table should just illustrate the important effect that a firm's past honoring behavior has on a firm's current honoring probability.

Table 5.9 divulges an important finding concerning the honoring likelihood: A high public engagement reputation increases the honoring probabilities in all instances. Furthermore, the corporations that are exposed to public engagements in $\mathrm{t}_{0}$, but not in $t-1$ have higher honoring probabilities than the corporations with public engagements in $t-1$. Hence, the repetitive public shareholder engagements might not pay off. Contrarily, in combination with the private engagement, I find that the private engagements in $\mathrm{t}_{0}$ and $t$ 1 even further increase the honoring likelihood. According to my model, the highest predicted honoring probability is $80.6 \%$. I find the honoring probability for a corporation that has the following engagement characteristics: public engagements in $t_{0}$, no public engagements in $t-1$, public engagement reputation of one, private engagements in $t_{0}$ and $t-1$, and a private engagement reputation of zero. It is important to stress the fact that the obtained predicted probabilities displayed in Table 5.9 are solely based on the fitted Model 1 in Table 5.8. Hence, the question is why the predicted probabilities in the lower right part of Table 5.9 - where no engagement at all take place at a particular corporation - are non-zero, at least in $t_{0}$ and $t-1$. I argue that this result is because there were already some engagements going on that could be honored in $t_{0}$. That is, the engagements initiated in $t-2$ or even earlier could be honored in $\mathrm{t}_{0}$, which causes the predicted probability to be positive. Essentially, I can derive all of the predicted probabilities for all kinds of corporations from Table 5.9.

\subsubsection{What are the effects for corporate governance engagements?}

In general, in Table 5.8, I find very similar effects for the entire universe of honored corporate governance engagements. Even though the coefficients are slightly smaller in their magnitude than for the entire sample, I find the same effects. The current private and public engagements significantly increase the odds that the corporations that were targeted with the governance engagements will honor at least one of them. As before, the presence of the public engagements in $t-1$ lowers the chances that a corporation will honor the CG engagements. The effect of a corporation's public engagement reputation is still positive but significant just at the $10 \%$ level.

However, I detect some important differences when I distinguish between honored public and private engagements. Model 3 of Table 5.8 displays the results for the private governance engagements, while Model 4 shows the results for the public engagements. The private corporate governance engagements are more likely to be honored by the corporations if there were both private and public engagements in year $t-1$, the year be- 
fore the honoring takes place. Other engagement variables do not affect the likelihood that the corporations accept the shareholders' concerns. On the other hand, for the public corporate governance engagements, I find that the same relations hold as for the entire sample of honored governance engagements. In particular, the past year's public engagement presence significantly suppresses the likelihood that the public governance engagements are honored. One explanation for this finding can be that the serious issues were discussed in the past year and that the settling of these issues is still pending or incompletely accomplished.

The remaining outcomes indicate that the public engagement reputation and the current and past private engagements significantly increase the honoring likelihood of the public governance engagements. The importance of the private engagements in the context of the honored public engagements could imply that the engagement agent is raising issues for which there were already some public engagement going on over the past couple of years. Hence, I argue there is a kind of bandwagon effect going on that implies that the engagement agent potentially picks up public events or public engagements and starts to engage on similar issues as well.

\subsubsection{Which effects do I find for CSR engagements?}

I conduct the same analysis as before but now for honored CSR engagements. The results for the successful CSR engagements in Table 5.8 differ substantially from those of the entire sample and corporate governance engagements. For the entire CSR honoring sample (Model 5), I find the same results for my public engagement control variables as before. That is, the current (past) public engagements increase (decrease) the honoring likelihood for the CSR engagements significantly. Furthermore, a corporation's public engagement reputation is positively related to the CSR honoring likelihood. However, the following findings differ from the ones obtained up to now. I find that out of the private engagement control variables, just the current private engagements significantly and negatively relate to the honoring likelihood of the CSR proposals. More precisely, I find that the corporations that receive the private engagements in the current year are less likely to display successful CSR engagements in the current period. Hence, more engagement on the private side lowers the success potential of shareholder engagement on particular social and environmental corporate policies. A direct, but still speculative, implication is that the institutional investors should not privately engage at the corporations for which they know that the public engagements are ongoing and were performed in the past - at least when the agent wants to achieve a corporate change with respect to the CSR policies. The remaining private engagement controls do not significantly affect the honoring likelihood of the CSR engagements.

Models 6 and 7 of Table 5.8 study the private and the public honored CSR engagements respectively. My results suggest that the likelihood of having successful private CSR engagements is basically not affected by any of the public engagement control variables. I conclude that the success of the private CSR engagements is completely independent of a corporation's reputation concerning the public engagements as well as any public engagements in the current and the past year. Concerning my private en- 
gagement control variables, the results point to a positive relation between the honored private CSR engagements and the past year's private engagements.

I find the completely reversed result for the public honored CSR engagements. None of the private engagement control variables exhibits a significant relation with the likelihood that the corporations will honor public CSR engagements. On the other hand, I find that the public engagements in $t-1$ and a corporation's public engagement reputation decrease and increase, respectively, the honoring likelihood for the public CSR engagements. To investigate which effect looms larger, I take a closer look at the predicted honoring probabilities for three kinds of corporations. The first corporation is an average corporation that exhibits just the public engagements in $t-1$. The second average corporation displays just a public engagement reputation of one, but has no public engagements in $t-1$. Lastly, I study the predicted probability for a corporation that has a public engagement in $t-1$ and whose public engagement reputation is equal to one. The first corporation has a predicted honoring likelihood of $32.2 \%$, the second $82.1 \%$, and the third $60 \%$. Comparing the second and the third corporations, I directly see that the past period's public engagements decrease the honoring likelihood by 22.1 percentage points to $60 \%$, which is of course still higher than the likelihood for corporation number one with just the public engagements in $t-1$. Hence, I infer from these results that the public CSR engagements are most likely honored when a corporation honored a lot of public shareholder engagement in the past.

\subsection{Summary and discussion}

In this chapter, I take a more holistic - though most likely still incomplete - view on shareholder engagement and provide the first indicative evidence on both facets of shareholder engagement: the private and the public shareholder engagements through private dialogues and shareholder proposals respectively.

My descriptive results indeed indicate that the shareholder engagement has a public and a private domain. I find that over time, the number of corporations that display the private engagements steadily increases. This increase also holds true for the public engagements. Still, a relatively large fraction of the potential engagement targets exhibit neither of the two engagements. On average, I find that those corporations that become targeted with private and/or public engagements exhibit more private engagements than public. However, even though the average number of public engagements is lower, the success rates are much higher for the public engagements. This is not surprising because I study just the engagement activities of one single (non-US) institutional investor whose power and influence cannot be as large as the engagement power of the entire shareholder base, the origin of the public engagement proxy.

My empirical results indicate the following important relations. Shareholder engagement seems to resemble a kind of repetitive game: the past public and the past private engagements significantly increase the odds that the same corporation becomes targeted in the subsequent period with any kind of engagement, whether private or public 
or even both. The past engagement success in the public engagement domain and to a lesser extent in the private engagement domain significantly reduce the likelihood that the corporations become targeted with any kind of engagement, especially public engagements.

Regarding the success of the shareholder engagement, I show that the past honored public engagements significantly increase the probability that the corporations will honor shareholder engagements of any kind today. This increase holds true for the full subsamples of corporate governance and the CSR engagements. Furthermore, I demonstrate that the presence of the past public engagements significantly reduces the probability of the public engagement success. On the other hand, the presence of the past private engagements has a significant and positive effect on the honoring likelihood. Generally, I find that the past public engagement success is positively related to the current engagement success but the effect is negative and nonsignificant for the past private successes. Furthermore, my results also disclose that the public (private) engagements are not relevant for the likelihood of the successful private (public) CSR engagements.

What do my results imply for shareholders, managers and researchers? Conceptually, I conjecture three important implications. First, my results suggest that especially, successful public engagements are a good predictor of future engagement successes of any kind. This is valuable information for institutional investors who have to carefully decide where to spend their scarce resources when it comes to engagement decisions. This is also important information for institutional investors who want to maximize the chances of the successful engagements. Based on this finding, the institutional investors should carefully focus their engagement resources on the corporations at which the current public shareholder engagements are ongoing and at which the past public engagements were relatively more successful (as far as it is observable).

Second, managers should be aware of the fact that the shareholder engagement can take place through public and private means. This fact implies that managers should not underestimate the power of the continuous private dialogues with important and presumably large institutional shareholders. These institutional investors are well-connected to other institutions and can therefore exert a lot of pressure against the corporations and the management teams through other channels rather than the engagement means studied in this chapter.

Third, researchers in the field of shareholder engagement should acknowledge the existence of the private and the public shareholder engagements. The public shareholder engagement, like the shareholder proposals (being probably the most visible and popular public engagement tool), is most likely a last resort mechanism to promote change at the corporations. Consistent with Chapter 3, I posit that most of the time, the institutional investors take the private route first and only later go public if the private negotiations fail. Hence, the researchers should treat the shareholder engagement process as a dynamic one that has several layers and dimensions. 



\section{CHAPTER 6 Conclusion}

Corporations around the world are earmarked by a separation between ownership and control: Their managers are hired by the shareholders to run the business on their behalf. Generally, the managers do not own significant stakes in the corporations they run. As Jensen and Meckling (1976) formally show, this fact can lead to agency costs of equity because the managers and the shareholders can have divergent interests. To align their interests, corporate governance mechanisms are put in place that should ensure that the corporations are run in the interest of the shareholders. The literature has investigated many different governance mechanisms: the market for corporate control (e.g., Gompers, Ishii, and Metrick, 2003), the product market (e.g., Giroud and Mueller, 2010), a corporation's capital structure (e.g., Jensen, 1986), the managerial ownership (e.g., Morck, Shleifer and Vishny, 1988), the large shareholders (e.g., Burkart, Gromb, and Panunzi, 1997), and the board of directors (e.g., Hermalin and Weisbach, 1991). Furthermore, the executive compensation and incentive contracts are also supposed to be governance mechanisms (e.g., Jensen and Murphy, 1999).

In this dissertation, I argue that shareholders as the owners of the corporation also have a direct corporate governance role through shareholder engagement. I claim that shareholders should raise their voice - as in the spirit of Hirschman (1970) - to become engaged and in doing so monitor the corporate management's actions and change its environmental, social, and governance policies if necessary.

I allege that this argument holds for all kinds of shareholders be they small, individual, retail investors or be they pension funds, insurance companies, labor unions, or any other large institutional investor. Due to the generally dispersed ownership structures of the large corporations, special importance is attached to the institutional investors. Generally, few individual shareholders really vote their proxies at the annual general meeting (AGM) or advise their custodian how to vote on their behalf. But, proxy voting can be a first step in raising their voice. Larger, mostly institutional, shareholders can do more than mere proxy voting because they have the economic power to do so. They can file 
shareholder proposals and enter into private engagements with the investee corporations. Hence, pension and mutual funds should also raise their voice on behalf of their clients and beneficiaries. Against the background of a growing demand for socially responsible and sustainable investments, I impute a special archetype function to the institutional investors: investing responsibly and sustainably means more than excluding particular stocks because of certain business models and including other stocks because of their relatively 'superior' environmental, social, or governance (ESG) standards. Investing responsibly also means shareholder engagement that promotes changes and sustainable ESG practices at investee corporations.

I arrive at these conclusions after having conducted four empirical studies on shareholder engagement. The main findings can be summarized as follows:

In Chapter 2, I study the shareholder engagement through proxy proposals in the United States from 1997-2006. Specifically, I research the determinants of the proposal occurrences and the drivers of the outcome levels of the voted shareholder proposals. This chapter distinguishes itself from the other papers on shareholder engagement through proposals, because I incorporate both the withdrawn and the omitted shareholder proposals in the analyses. This inclusion implies that my results are based on a cleaner data set because I treat the withdrawn and the omitted proposals as 'filed' shareholder proposals. The main hypothesis of Chapter 2 is as follows: The lack of industry competition in combination with the higher managerial entrenchment increases the likelihood of the corporations being targeted with the shareholder proposals. My empirical results support this hypothesis. The poorly governed corporations, in terms of product market competition and exposure to the managerial labor market, are more likely to receive the shareholder proposals. Therefore, I claim that the shareholders are capable of selecting those corporations for which the shareholder engagement is necessary. Concerning proposal effectiveness, I find that the insiders' equity holdings have a significant and negative effect on the total voting outcomes of the shareholder proposals. Hence, I argue that the managers either explicitly vote against the shareholder proposals or that they at least signal to important and powerful shareholders that a supporting vote for particular shareholder proposals is not beneficial to the corporation.

Chapter 3 turns the perspective from the voted shareholder proposals to those proposals that are withdrawn prior to the AGM. The analysis is based on more than 12,000 shareholder proposals that were filed at S\&P1500 corporations from 1997-2009. Out of all of the filed shareholder proposals, more than 2,500 (or 20\%) were withdrawn prior to the AGM. The proposals sponsored by the institutional investors and the labor unions are on average more frequently withdrawn than the proposals filed by the individual investors and the coordinated interest groups. As the title of this chapter suggests, I am particularly interested in the drivers of the proposals' withdrawals. My empirical results suggest that the institutional ownership is positively related to the withdrawal's likelihood. By categorizing the institutional investors, I show that especially the ownership of the long-term, passively investing institutions significantly increase the odds of a proposal's withdrawal. My proposal-level analysis shows that conditional on the fact that a proposal is filed by an institutional investor, the effect of the institutional ownership stake becomes even larger. Chapter 3 also demonstrates a negative relation between the insider 
ownership and the withdrawal's likelihood. This finding reflects the increased bargaining power of the managers when they hold relatively more shares.

Chapter 3 generally investigates the public shareholder engagement through the shareholder proposals. However, Chapter 3 also contains a private facet of engagement: the private negotiations following the public filing of a proposal. Chapter 4 then turns to the completely private domain of the shareholder engagement: the private shareholder engagement of a large institutional investor.

In Chapter 4, I investigate the global engagement activities of a large UK-based asset manager. This asset manager undertakes the shareholder engagement on behalf of several institutional clients. Hence, the economic power standing behind the asset manager is enormous. In contrast to other studies on private engagements (e.g., Dimson, Karakas, and Li, 2013, Carleton, Nelson, and Weisbach, 1998 and Chapter 5), I provide the first global evidence on private shareholder engagement by studying 397 corporations from 37 different countries. My main research hypothesis is that there is a home bias in both the engagement intensity as well as in the engagement success. The empirical results confirm my hypothesis: the engagement intensity is significantly higher at UK corporations. Consistent with Chapter 2, I find that the larger corporations receive significantly more private engagements than their smaller counterparts. I interpret this finding as evidence in favor of the argument that the larger corporations are more likely to be in the asset manager's and its clients' portfolios and hence, make up for a substantial portion of the entire investment portfolio. Therefore, engagement at these corporations is of particular importance. Interestingly, I am able to show that the asset manager's past engagement efforts are important determinants of the current engagement activities. The private engagements apparently are a product of the long-term relationship between the engagement agent and the portfolio corporations. I also discover that geography is an important driver of the engagement success: The corporations from the United States and Continental Europe have on average significantly more successful engagements than their UK counterparts. I come up with two potential explanations for this latter finding. First, the engagement agent targets specifically those foreign corporations for which the necessity of engagement is also the highest and which therefore have the highest potential to change. Second, the UK corporations have tight nationwide regulations with respect to corporate governance and environmental standards that limits the potential of change in domestic corporations.

Chapter 5 of this dissertation combines the research efforts undertaken in the previous chapters. In this chapter, I study both the private and the public engagements at the same time to uncover their interdependencies and their simultaneous effects on the corporation's likelihood of being targeted and of honoring its engagements. Conceptually, Chapter 5 consists of three parts. First, I document the evolution of the private and the public shareholder engagements at US corporations from 1999-2011. Second, I study the determinants of the occurrences of both the private and the public shareholder engagements. And third, I investigate the drivers of the successful engagements with a particular focus on the presence of both engagements and a corporation's engagement history. 
I rely on the private engagement data from the same UK-based asset manager as in Chapter 4. However, this time, I only use the engagement data for US corporations. I combine this proprietary engagement data with the public data on the shareholder proposals to study the aforementioned research objectives. The results of this chapter indicate that the shareholder engagement indeed consists of both public and private domains. The corporations are exposed to either the public or the private engagements or sometimes both. However, I find that most of the corporations in the sample are still not targeted with any kind of engagement.

Regarding the determinants of the targeting likelihood, I show the following. After controlling for the corporate characteristics and the industry and year effects, I find that those corporations that have the highest predicted targeting likelihood have both public and private engagements in the previous year and a low reputation regarding both engagements.

Turning the perspective to the honoring likelihood, I find several important issues. A corporation must have the following characteristics to have the highest predicted honoring likelihood-given my empirical model: First, the corporation must have both private and public engagements in the current period (where honoring takes place). Second, there must be private engagements in the previous period, but no public engagements. Lastly, a corporation must have a high public engagement reputation and a low private reputation.

What implications my thesis has for investors, managers, and researchers is outlined in the next sections.

\subsection{Implications of this dissertation}

Many implications can be derived from my dissertation, some of which have already been discussed within the corresponding chapters. I mentioned in the introduction that the shareholders have the responsibility to oversee the management's actions and to monitor corporate behavior. What my dissertation shows is that quite a bit of shareholder engagement already exists especially through the shareholder proposals and the private engagements. Apparently, the shareholders became aware of their monitoring duty after certain scandals like Enron and Worldcom and after the financial crises. However, my dissertation results also imply that there is a potential upside to the shareholder engagement.

I argue that based on my results, more institutional shareholder involvement is needed. As I mentioned in the introduction to this thesis, institutional investors could and also should go beyond mere proxy voting. The institutional investors should become more active by filing shareholder proposals or even privately engaging - either themselves or through an engagement agency.

For example, I find that the shareholder proposal mechanism is frequently used by shareholders to influence corporate behavior. I find that a lot of individual, retail investors are filing shareholder proposals. Interestingly, my results show that the proposals of 
individual investors are least successful in terms of their voting outcomes and their withdrawal probabilities. The institutional investors, on the other hand, file fewer proposals compared to the individual investors but are on average more successful. Hence, I attribute an even more important monitoring role to the institutional investors. They have the incentives, the knowledge, the resources, and the economic power to really change corporate behavior. The institutional investors should therefore act more collectively with other institutional investors but also the individual investors to make the proposal mechanism even more effective. I am not advocating a type of "acting in concert" engagement, I am just asking for a closer collaboration between the shareholders to decently scrutinize the investee corporations regarding their corporate behavior.

Also, there has to be a consensus between the institutional investors on what topics exactly to engage in with the corporations. One way of dealing with this issue is the private engagements discussed in Chapters 4 and 5. Sometimes, the shareholders have divergent interests and are possibly lobbying for opposite issues. Pooling resources through an engagement agent might help in this instance. This engagement agent could collect the needs and the views of every client and then design a common engagement policy. In doing so, the economic power behind the engagement activities could be much larger and therefore be more likely to be heard by the managers.

Much of today's discussion is about responsible investing and the sustainability of corporations. Topics like reasonable executive pay practices, human rights standards, and global warming are more prevalent than ever. Many individual shareholders as well as the institutional investors are more and more willing to generate returns by relying on socially responsible investments. Some examples are pension funds, churches, or socially responsible mutual funds. These investors generally screen certain potential investments. This screening assesses the ESG quality of the particular corporations and, based on this judgment, are included in the portfolio or not. Often, the first exclusion criteria for these investors is the fact that particular corporations are doing business in the sin industries like tobacco, gambling, or military defense. Another exclusion criteria might be the UN Principles for Responsible Investment, which has become more or less a standard. In conclusion, particular investors walk away from particular corporations or even do not start investing in them because they want socially responsible and sustainable investments. However, referring back to my introduction, are these investment strategies really responsible? Given the results of my dissertation, I claim not.

The institutional investors who have certain moral or ethical investment beliefs and standards because their beneficiaries and clients demand them can do more than just exclude particular corporations. They can promote sustainability and responsibility standards at those corporations and change them for the better. In doing so, they could invest in a responsible way because they do not simply leave corporations operating in the ways they currently are.

By no means do I advocate that shareholders should try to change a corporation's line of business or anything like that. Rather, I challenge the claim that certain ESG standards cannot be changed by shareholders even though particular corporations are operating in industries that do not comply with particular moral standards. As my results show, human rights policies, worker safety standards, or reasonable executive pay prac- 
tices can even be promoted by shareholders at those corporations. Shareholders have to realize this opportunity, but they also have a duty to do so.

Consistent with my previous claim, I am going to again stress that I do not postulate that shareholders - whether large institutions or individuals - should interfere with the day-to-day business of corporations. The public nature of corporations requires that the complex management tasks are 'delegated' to the top managers with the expertise to run the businesses. In fact, it is impossible for all kinds of shareholders to get a clear picture of how a corporation is run or how it should be run. The knowledge and expertise of the shareholders is simply not sufficient to arrogate the corporate policies by demanding certain changes. However, more general policies like the implementation of worker safety standards, human rights policies, or the introduction of more environmentally friendly policies can be raised by shareholders.

\subsection{Suggestions for future research}

The literature on shareholder engagement is growing rapidly. However, it is still in its infancy; much more has to be researched to make the definitive conclusions about the effectiveness and societal as well as economic additional benefit the shareholder engagement creates - or does not. In this dissertation, I attempt to add to the literature, but several more possibilities exist that can continue the research path that I have taken.

First, much more research has to be done in different legal jurisdictions. Out of the four chapters of this dissertation, three are concerned with the United States. Also, much of the corporate finance literature focuses on Anglo-Saxon countries, if not only on the United States However, the shareholder engagement is undertaken by completely different means in different legal jurisdictions and its potential to create benefits is also dependent on the underlying legal system. The ownership regimes of Anglo-Saxon countries are very distinct from other, more bank-based countries, like Japan or Germany. There, the equity ownership is concentrated in the hands of the banks, financial institutions, and other corporations whereas the equity ownership in Anglo-Saxon countries is much more dispersed. Therefore, it might be very interesting to investigate how the shareholder engagement works in bank-based systems. Is it more effective in those jurisdictions? What are the obstacles that the institutional investors have to overcome in those markets? Does the engagement approach differ compared to the engagement in the Anglo-Saxon world? These kind of questions are interesting avenues for the future research on this topic.

Second, we as researchers have to look much deeper into the "bargaining game" that managers are playing with shareholders who engage. As I discuss in Chapters 3 and 4, there is always the possibility that the management teams surrender and implement, for example, particular CSR policies just to circumvent the introduction of much tougher governance standards that could erode their power and potentially their compensation. We have to understand what exactly is going on behind the scenes by looking at the interdependencies of the detailed engagements on a particular topic. 
Third, the literature on shareholder engagement so far lacks evidence on the reputational costs for corporations who do not honor their engagements. So far, the evidence, and also this dissertation, tries to establish a link between the successful shareholder engagement and the benefits to the shareholders. Notwithstanding, it is of great importance to investigate if and how the corporations suffer from not honoring the major shareholders' engagements. In particular, do these corporations suffer from losses in reputation? Do these corporations have lower analyst coverage? Do these corporations have less institutional ownership? These are in my view the relevant questions that also emphasize the connection between the shareholder engagement and particular corporate finance topics.

Fourth, it is important to realize that my dissertation focuses on the shareholder engagement. However, a corporation has more capital providers, for example bondholders. As a matter of fact, the bondholders do not necessarily share the same interests as the shareholders. Hence, it might be important to shed more light on the consequences of the shareholder engagement for the bondholders. From a practical viewpoint, this is also important for large institutional investors: How does an investor engage with the corporations when he or she holds both an equity and a debt position in a particular corporation? Answering this question could help to increase the effectiveness of the engagement and possibly to reduce the conflicting interests within the organizations of the institutional investors.

My dissertation is just the start at looking into the private shareholder engagements. It will be interesting to see whether similar studies on multiple institutional investors will be conducted to see how successful the pooled institutional ownership base that engages for more sustainable and responsible corporations will be. 



\section{Bibliography}

Admati, A. R. and Pfleiderer, P. (2009). The "Wall Street Walk" and Shareholder Activism: Exit as a Form of Voice. Review of Financial Studies, 22(7), 2645-2685.

Agrawal, A. K. (2012). Corporate Governance Objectives of Labor Union Shareholders: Evidence from Proxy Voting. Review of Financial Studies, 25(1), 187-226.

Ashraf, R., Jayaraman, N., and Ryan Jr., H. E. (2009). Conflicts of Interest and Mutual Fund Proxy Voting: Evidence from Shareholder Proposals on Executive Compensation. Working Paper: Georgia State University.

Baik, B., Kang, J.-K., and Kim, J. M. (2010). Local Institutional Investors, Information Asymmetries and Equity Returns. Journal of Financial Economics, 97, 81-106.

Bauer, R. and Braun, R. (2010). Misdeeds Matter: Long-Term Stock Price Performance after the Filing of Class-Action Lawsuits. Financial Analysts Journal, 66(6), 74-92.

Bauer, R., Braun, R. and Viehs, M. (2012). Industry Competition, Ownership Structure and Shareholder Activism. ECCE Working Paper: Maastricht University.

Bauer, R., Bos, J., Derwall, J., and Viehs, M. (2013). The Market for Public and Private Engagement. Unpublished ECCE Working Paper: Maastricht University.

Bauer, R., Clark, G. L., and Viehs, M. (2013). The Geography of Shareholder Engagement. Evidence from a Large British Asset Manager. ECCE Working Paper: Maastricht University and Oxford University.

Bauer, R., Moers, F., and Viehs, M. (2013). The Determinants of Withdrawn Shareholder Proposals. ECCE Working Paper: Maastricht University.

Bebchuk, L., Cohen, A., and Ferrell, A. (2009). What Matters in Corporate Governance? Review of Financial Studies, 22(2), 783-827.

Bebchuk, L., Cohen, A., and Wang, C. C. Y. (2013). Learning and the Disappearing Association between Governance and Returns. Journal of Financial Economics, $108(2), 323-348$.

Becht, M., Bolton P., and Röell, A. (2003). Corporate Governance and Control. In: G.M. Constantinides, M. Harris, and R. Stulz, Eds., Handbook of the Economics of Finance. North Holland, Amsterdam, 22-120.

Becht, M., Franks, J., Mayer, C., and Rossi, S. (2009). Returns to Shareholder Activism: Evidence from a Clinical Study of the Hermes UK Focus Fund. Review of Financial Studies, 22(8), 3093-3129.

Berger, P. G., Ofek, E., and Yermack, D. L. (1997). Managerial Entrenchment and Capital Structure Decisions. Journal of Finance, 52(4), 1411-1438.

Bertrand, M. and Mullainathan, S. (2003). Enjoying the Quiet Life? Corporate Governance and Managerial Preferences. Journal of Political Economy, 111(5), 1043-1075.

Berle, A. and Means, G. (1932). The Modern Corporation and Private Property. Transaction Publishers: New Jersey. 
Bodnaruk, A. (2009). Proximity Always Matters: Local Bias when the Set of Local Companies Changes. Review of Finance, 13, 629-656.

Bodnaruk, A. and Östberg, P. (2013). Shareholder Base and Payout Policy. Journal of Financial and Quantitative Analysis, forthcoming.

Brav, A., Jiang, W., and Kim, H. (2011). The Real Effects of Hedge Fund Activism: Productivity, Risk, and Product Market Competition. NBER Working Paper No. 17517, Duke University and Columbia University.

Brav, A., Jiang, W., Partnoy, F., and Thomas, R. (2008). Hedge Fund Activism, Corporate Governance, and Firm Performance. Journal of Finance, 63(4), 1729-1775.

Buchanan, B., Netter, J. M., Poulsen, A. B., and Yang, T. (2012). Shareholder Proposal Rules and Practice: Evidence from a Comparison of the United States and United Kingdom. American Business Law Journal, 49(4), 739-803.

Burkhart, M., Gromb, D., and Panunzi, F. (1997). Large Shareholders, Monitoring, and the Value of the Firm. The Quarterly Journal of Economics, 112(3), 693-728.

Bushee, B. J. (1998). The Influence of Institutional Investors on Myopic R\&D Investment Behavior. The Accounting Review, 73(3), 305-333.

Bushee, B. J. (2001). Do Institutional Investors Prefer Near-Term Earnings over LongRun Value? Contemporary Accounting Research, 18(2), 207-246.

Bushee, B. J. and Miller, G. S. (2012). Investor Relations, Firm Visibility, and Investor Following. The Accounting Review, 87(3), 867-897.

Bushee, B. J. and Noe, C. F. (2000). Corporate Disclosure Practices, Institutional Investors, and Stock Return Volatility. Journal of Accounting Research, 38 (Supplement: Studies on Accounting Information and the Economics of the Firm), 171-202.

Carleton, W. T., Nelson, J. M., and Weisbach, M. S. (1998). The Influence of Institutions on Corporate Governance through Private Negotiations: Evidence from TIAACREF. Journal of Finance, 53(4), 1335-1362.

Chhaochharia, V., Kumar, A. and Niessen-Ruenzi, A. (2012). Local Investors and Corporate Governance. Journal of Accounting and Economics, 54, 42-67.

Chen, X., Harford, J., and Li, K. (2007). Monitoring: Which Institutions Matter? Journal of Financial Economics, 86, 279-305.

Chidambaran, N. K. and Woidtke, T. (1999). The Role of Negotiations in Corporate Governance: Evidence from Withdrawn Shareholder-Initiated Proposals. New York University, Center for Law and Practice Working Paper.

Core, J. and Guay, W. (1999). The Use of Equity Grants to Manage Optimal Equity Incentive Levels. Journal of Accounting and Economics, 28, 151-184.

Core, J. and Guay, W. (2002). Estimating the Value of Employee Stock Option Portfolios and Their Sensitivities to Price and Volatility. Journal of Accounting Research, 40(3), 613-630.

Core, J., Holthausen, R. W., and Larcker, D. F. (1999). Corporate Governance, Chief Executive Officer Compensation, and Firm Performance. Journal of Financial Economics, 51, 371-406.

Cornett, M. M., Marcus, A. J., Saunders, A., and Tehranian, H. (2007). The Impact of Institutional Ownership on Corporate Operating Performance. Journal of Banking and Finance, 31, 1771-1794. 
Coval, J. D. and Moskowitz, T. J. (1999). Home Bias at Home: Local Equity Preference in Domestic Portfolios. Journal of Finance, 54(6), 2045-2073.

Coval, J. D. and Moskowitz, T. J. (2001). The Geography of Investment: Informed Trading and Asset Prices. Journal of Political Economy, 109(4), 811-841.

Davis, G. F., and Kim, E. H. (2007). Business Ties and Proxy Voting by Mutual Funds. Journal of Financial Economics, 85, 552-570.

DeAngelo, H. and DeAngelo, L. (1985). Managerial Ownership of Voting Rights. A Study of Public Corporations with Dual Classes of Common Stock. Journal of Financial Economics, 14, 33-69.

Del Guercio, D. and Hawkins, J. (1999). The Motivation and Impact of Pension Fund Activism. Journal of Financial Economics, 52(3), 293-340.

Del Guercio, D., Seery, L., and Woidtke, T. (2008). Do Boards Pay Attention when Institutional Investor Activists "just vote no"? Journal of Financial Economics, 90(1), 84-103.

Demsetz, H. and Lehn, K. (1985). The Structure of Corporate Ownership: Causes and Consequences. Journal of Political Economy, 93(6), 1155-1177.

Demsetz, H. and Villalonga, B. (2001). Ownership Structure and Corporate Performance. Journal of Corporate Finance, 7, 209-233.

Dimson, E., Karakas, O. and. Li, X. (2013). Active Ownership. Working Paper: London Business School, Boston College and Temple University.

Djankov, S., La Porta, R., Lopez-de-Silanes, F., and Shleifer, A. (2008). The Law and Economics of Self-Dealing. Journal of Financial Economics, 88, 430-465.

Edmans, A. (2009). Blockholder Trading, Market Efficiency, and Managerial Myopia. Journal of Finance, 64(6), 2481-2513.

Edmans, A., Gabaix, X., and Landier, A. (2009). A Multiplicative Model of Optimal CEO Incentives in Market Equilibrium. The Review of Financial Studies, 22(12), 4881-4917.

Edmans, A. and Manso, G. (2011). Governance Through Trading and Intervention: A Theory of Multiple Blockholders. The Review of Financial Studies, 24(7), 23952428.

Ertimur, Y., Ferri, F., and Muslu, V. (2011). Shareholder Activism and CEO Pay. Review of Financial Studies, 24(2), 535-592.

Ertimur, Y., Ferri, F., and Stubben, S.R. (2010). Board of Directors' Responsiveness to Shareholders: Evidence from Shareholder Proposals. Journal of Corporate Finance, $16,53-72$.

Fama, E. F. and Jensen, M. C. (1983). Separation of Ownership and Control. Journal of Law and Economics, 26(2), 301-325.

Ferreira, M. A. and Matos, P. (2008). The Colors of Investors' Money: The Role of Institutional Investors Around the World. Journal of Financial Economics, 88, 499533.

Ferri, F. and Sandino, T. (2009). The Impact of Shareholder Activism on Financial Reporting and Compensation: The Case of Employee Stock Options Expensing. The Accounting Review, 84(2), 433-466. 
Gande, A. and Lewis, C. M. (2009). Shareholder-Initiated Class Action Lawsuits: Shareholder Wealth Effects and Industry Spillovers. Journal of Financial and Quantitative Analysis, 44(4), 823-850.

Gillan, S. L. and Starks, L. T. (2000). Corporate Governance Proposals and Shareholder Activism: The Role of Institutional Investors. Journal of Financial Economics, 57, $275-305$.

Gillan, S. L. and Starks, L. T. (2007). The Evolution of Shareholder Activism in the United States. Journal of Applied Corporate Finance, 19(1), 55-73.

Giroud, X. and Mueller, H. M. (2010). Does Corporate Governance Matter in Competitive Industries? Journal of Financial Economics, 95, 312-331.

Giroud, X. and Mueller, H. M. (2011). Corporate Governance, Product Market Competition and Equity Prices. Journal of Finance, 66(2), 563-600.

Gompers, P., Ishii, J., and Metrick, A. (2003). Corporate Governance and Equity Prices. The Quarterly Journal of Economics, 118(1), 107-155.

Gordon, L. A. and Pound, J. (1993). Information, Ownership Structure, and Shareholder Voting: Evidence From Shareholder-Sponsored Corporate Governance Proposals. Journal of Finance, 48(2), 697-718.

Grossman, S. J. and Hart, O. D. (1980). Takeover Bids, the Free-Rider Problem, and the Theory of the Corporation. The Bell Journal of Economics, 11(1), 42-64.

Grullon, G., Kanatas, G., and Weston, J. P. (2004). Advertising, Breadth of Ownership, and Liquidity. The Review of Financial Studies, 17(2), 439-461.

Hall, B. J. and Liebman, J. B. (1998). Are CEOs Really Paid Like Bureaucrats? The Quarterly Journal of Economics, 113(3), 653-691.

Hart, O. D. (1983). The Market Mechanism as an Incentive Scheme. The Bell Journal of Economics, 14(2), 366-382.

Hirschman, A. O. (1970). Exit, Voice, and Loyalty: Responses to Decline in Firms, Organizations, and States. Harvard University Press: Cambridge, MA.

Hermalin, B. E. and Weisbach, M. S. (1991). The Effects of Board Composition and Direct Incentives on Firm Performance. Financial Management, 20(4), 101-112.

Huberman, G. (2001). Familiarity breeds investment. Review of Financial Studies, 14(3), 659-680.

Hong, H. and Kacperczyk, M. (2009). The Price of Sin: The Effects of Social Norms on Markets. Journal of Financial Economics, 93(1), 15-36.

Hong, H. G., Kubik, J. D., and Scheinkmann, J. A. (2012). Financial Constrains on Corporate Goodness. Working Paper: Princeton University and Syracuse University.

Ivkovic, Z. and Weisbenner, S. (2005). Local Does as Local Is: Information Content of the Geography of Individual Investors' Common Stock Investments. Journal of Finance, 60(1), 267-306.

Jensen, M. C. (1986). Agency Costs of Free Cash Flow, Corporate Finance, and Takeovers. American Economic Review, 76(2), 323-329.

Jensen, M. C. and Meckling, W. H. (1976). Theory of the Firm: Managerial behavior, Agency Costs and Ownership Structure. Journal of Financial Economics, 3(4), 305360 . 
Jensen, M. C. and Murphy, K. (1990). Performance Pay and Top-Management Incentives. Journal of Political Economy, 98(2), 225-264.

John, K. and Kadyrzhanova, D. (2008). Relative Governance. New York University and University of Maryland Working Paper.

John, K. and Klein, A. (1995). Shareholder Proposals and Corporate Governance. New York University Working Paper.

Kahn, C. and Winton, A. (1998). Ownership Structure, Speculation, and Shareholder Intervention. Journal of Finance, 53(1), 99-129.

Karpoff, J. M., Malatesta, P. H., and Walkling, R. A. (1996). Corporate Governance and Shareholder Initiatives: Empirical Evidence. Journal of Financial Economics, 42, 365-395.

Klein, A. and Zur, E. (2009). Entrepreneurial Shareholder Activism: Hedge Funds and Other Private Investors. Journal of Finance, 64(1), 187-229.

Landier, A. and Nair, V. B. (2009). Investing For Change. Profit from Responsible Investment. Oxford University Press: Oxford and New York,

La Porta, R., Lopez-de-Silanes, F., Shleifer, A., and Vishny, R. (1998). Law and Finance. Journal of Political Economy, 106(6), 1113-1155.

La Porta, R., Lopez-de-Silanes, F., and Shleifer, A. (1999). Corporate ownership around the world. Journal of Finance, 54(2), 471-517.

La Porta, R., Lopez-de-Silanes, F., Shleifer, A., and Vishny, R. (2000a). Investor Protection and Corporate Governance. Journal of Financial Economics, 58, 3-27.

La Porta, R., Lopez-de-Silanes, F., Shleifer, A., and Vishny, R. (2000b). Agency Problems and Dividend Policies Around the World. Journal of Finance, 55(1), 1-33.

Loss, L. and Seligman, J. (2004). Fundamentals of Securities Regulation. $5^{\text {th }}$ edition. Aspen Publishers: New York.

McCahery, J. A., Sautner, Z., and Starks, L. T. (2013). Behind the Scenes: The Corporate Governance Preferences of Institutional Investors. Working Paper: Tilburg University, University of Amsterdam, and University of Texas.

Mian, A. (2006). Distance Constraints: The Limits of Foreign Lending in Poor Economies. Journal of Finance, 61(3), 1465-1505.

Morck, R., Shleifer, R., and Vishny, R. W. (1988). Management Ownership and Market Valuation: An Empirical Analysis. Journal of Financial Economics, 20, 293-315.

Petersen, M. A. and Rajan, R. G. (2002). Does Distance Still Matter? The Information Revolution in Small Business Lending. Journal of Finance, 57(6), 2533-2570.

Prevost, A. K. and Rao, R. P. (2000). Of What Value Are Shareholder Proposals Sponsored by Public Pension Funds? Journal of Business, 73(2), 177-204.

Prevost, A. K., Rao, R. P., and Williams, M. A. (2012). Labor Unions as Shareholder Activists: Champions or Detractors? The Financial Review, 47, 327-349.

Romano, R. (1991). The Shareholder Suit: Litigation without Foundation? Journal of Law, Economics and Organization, 7(1), 55-87.

Shleifer, A. and Vishny, R. W. (1986). Large Shareholders and Corporate Control. Journal of Political Economy, 94(3), 461-488.

Shleifer, A. and Vishny, R. W. (1997). A Survey of Corporate Governance. Journal of Finance, 52(2), 737-783. 
Smith, M. P. (1996). Shareholder Activism by Institutional Investors: Evidence from CalPERS, Journal of Finance 51(1), 227-252.

Thomas, R. S. and Martin, K. J. (1999). The Effect of Shareholder Proposals on Executive Compensation. University of Cincinnati Law Review, 67, 1021-1081.

Tirole, J. (2006). The theory of corporate finance. Princeton University Press: Princeton, New Jersey.

Wahal, S. (1996). Pension Fund Activism and Firm Performance. Journal of Financial and Quantitative Analysis, 31(1), 1-23.

White, H. (1980). A Heteroskedasticity-Consistent Covariance Matrix Estimator and a Direct Test for Heteroskedasticity. Econometrica, 48(4), 817-838.

Yermack, D. L. (2010). Shareholder Voting and Corporate Governance. Annual Review of Financial Economics, 2, 103-125. 


\section{Deutsche Zusammenfassung (Summary in German)}

Die vorliegende Dissertation beschäftigt sich mit dem Thema Corporate Governance, der Bezeichnung für gute Unternehmensführung und -kontrolle. Der Begriff Corporate Governance, wie er in dieser Arbeit definiert wird, beinhaltet alle Maßnahmen und Mechanismen, die von internen sowie externen Interessengruppen genutzt werden können, um börsennotierte Unternehmen und deren Geschäftspraktiken zu kontrollieren, zu beeinflussen, aber auch um Managementverhalten nachhaltiger zu gestalten. Dazu zählt auch die kritische Auseinandersetzung mit Vergütungs- und Anreizmechanismen, die in der Regel installiert werden, um die Interessenkonflikte zwischen UnternehmensEigentümern - den Aktionären - und den Managern zu reduzieren, wie schon durch Jensen und Meckling im Jahre 1976 belegt wurde.

Eine besondere Rolle bei der Corporate Governance schreibt diese Dissertation den Eigentümern börsennotierter Unternehmen zu: den Aktionären. Als direkte Eigentümer der Unternehmen haben Aktionäre die Aufgabe, Kontrolle über Manager und die Geschäftspraktiken der einzelnen Unternehmen auszuüben. In der Regel investieren Kleinanleger in Aktien, ohne sich bewusst zu sein, dass sie durch den Kauf eines Aktienteils zugleich Eigentümer des Unternehmens werden. Zumeist werden einzelne Aktienpakete gehalten, ohne direkte Kontrolle auszuüben. Dabei hat jeder Aktionär die Gelegenheit mindestens einmal jährlich mittels Stimmrechtsausübung auf der Jahreshauptversammlung (JHV) eines börsennotierten Unternehmens über Geschäftspolitik, Managementvergütungen, oder die Zusammensetzung des Aufsichtsrates direkte Kontrolle auszuüben. Leider findet diese Aktionärsbeteiligung von Kleinanlegern noch nicht häufig genug statt. Der Grund für dieses Verhalten ist laut Grossman und Hart (1980) vor allem das so genannte Free-Rider Verhalten (Trittbrettfahrerverhalten), das vor allem bei im weiten Streubesitz befindlichen Unternehmen auftritt: $\mathrm{Zu}$ geringe Anteilspositionen bringen nicht genügend Anreize mit sich, um Kontrolle auf Manager auszuüben, da die Kosten den ökonomischen Nutzen - der mit allen anderen Aktionären geteilt werden muss - meistens übersteigen. Daher veräußern Kleinanleger eher ihre Aktien, sobald sie mit der finanziellen Performance des Unternehmens oder mit dessen ökologischen, sozialen und ethischen Standards unzufrieden sind, als dass sie aktiv einen Veränderungsprozess anstoßen.

Daher kommt vor allem den großen, institutionellen Anlegern, wie z.B. Pensionskassen, Versicherungen, und Investmentfonds eine Corporate Governance Rolle zu, wie auch durch Shleifer und Vishny (1997) beschrieben. Diese institutionellen Anleger halten vergleichsweise große Anteile an börsennotierten Firmen und haben dementsprechend einen größeren finanziellen Anreiz sicherzustellen, dass das Unternehmen in 
ihrem Sinne geleitet und ein langfristiger Planungsansatz verfolgt wird. Heutzutage werden institutionelle Anleger auch durch ihre eigenen Kunden und durch ihre Benefizianten, wie Pensionäre und Investmentfonds-Anleger, dazu angehalten, die Geschäftspraktiken der einzelnen Anlagepositionen genauer zu beleuchten und kritisch zu hinterfragen. Dabei steht oftmals der Grundgedanke eines nachhaltigen Investments-Ansatzes im Vordergrund, wie weiter unten beschrieben wird.

Diese Dissertation argumentiert, dass ökologische, soziale und ethische Belange stärker von Anlegern in den Unternehmensgestaltungsprozess mit eingebracht werden müssen. In Zeiten von Klimaerwärmung, Umweltverschmutzung, MenschenrechtsVerletzungen in Produktionsprozessen, sowie die Nichteinhaltung von Sicherheitsstandards, haben vor allem die Eigentümer und Investoren eine direkte Pflicht, Unternehmen dahingehend zu kontrollieren und zu verändern, sodass die Geschäftspraktiken nachhaltiger ausgestaltet werden, und Manager noch verantwortlicher die Geschicke der ihnen anvertrauten Firmen leiten. Ich argumentiere, dass sich vor allem die Eigentümer der Unternehmen einbringen sollen, um bessere soziale, ökologische, und ethische Standards durchzusetzen, damit eine Rendite nicht um jeden Preis erwirtschaftet wird.

Daher fordert die vorliegende Dissertation - folgend dem Titel der Arbeit - eine aktive Eigentumskultur unter Aktionären: Active ownership. Zu oft werden die Anteile an Unternehmen als passive Investments betrachtet, die keine direkten Pflichten nach sich ziehen. Ich argumentiere, dass genau das Gegenteil der Fall ist: Anleger haben eine Pflicht, sich aktiv an der Corporate Governance eines Unternehmens zu beteiligen. Dies gilt sowohl für die direkten Aktionäre als auch für Vermögensverwalter, die eine Pflicht haben, im Sinne ihrer Benefizianten das ihnen anvertraute Vermögen zu verwalten. Warum ist dies der Fall?

Kleinanleger, Pensionäre und Versicherungsnehmer verlangen immer öfter, dass ihre Renditen nachhaltig und verantwortlich erwirtschaftet werden, das heißt, dass ökologische, soziale und ethische Standards von den investierten Firmen eingehalten werden. In der Finanzbranche wird oftmals proklamiert, dass durch das Implementieren sogenannter „Ausschlusskriterien“ verantwortlich und nachhaltig investiert werde. Diese Ausschlusskriterien folgen vorab bestimmten Faktoren, die dazu herangezogen werden, um zu überprüfen, ob ein Unternehmen in das Investitionsportfolio aufgenommen werden kann oder nicht. Diese Kriterien schließen von vornherein die Industrien aus, die gemeinhin als sin industries (Sünden-Industrien) bezeichnet werden, also all die Firmen, die zum Beispiel in den Geschäftsfeldern Tabakproduktion, Glücksspiel, Alkoholproduktion und -vertrieb, sowie Waffenproduktion tätig sind. Ob das Ausschließen von ganzen Industrien als Anlagemöglichkeit finanziell sinnvoll ist, sei an dieser Stelle dahingestellt. Es wurde jedoch von Hong und Kascperzcyk (2009) belegt, dass vor allem diese Sünden-Industrien positive Renditen abwerfen, die über der durchschnittlichen Renditeerwartung einer konventionellen Industrie liegen.

Des Weiteren werden in der Finanzbranche so genannte „Auswahlkriterien“ herangezogen, die dazu dienen, die besten Unternehmen einer jeden Industrie hinsichtlich derer ökologischen, sozialen und ethischen Leistung für das Investitionsportfolio auszuwählen. Dabei werden die Firmen mittels sogenannter ökologischer und sozialer Ra- 
tings herausgefiltert, die hinsichtlich dieser Aspekte eine relativ schlechtere Performance abliefern.

Meine Dissertation wirft daher die Frage auf, ob durch das Implementieren dieser beiden Methoden, also das einfach Ausschließen von bestimmten Firmen und Industrien sowie das Investieren in die relativ besten Unternehmen hinsichtlich Ökologie, Sozialem, und Ethik, wirklich verantwortliches und nachhaltiges Investieren ist. Meine Antwort auf diese Frage lautet Nein.

Ich behaupte in dieser Arbeit, dass institutionelle Investoren nicht nachhaltig und verantwortlich investieren, wenn sie bestimmte Industrien und Firmen nicht in ihr Anlageportfolio aufnehmen. Grundlage dieser Behauptung sind die Ergebnisse von Bebchuk, Cohen, und Yang aus dem Jahre 2013. Bis dahin galt es als profitabel, in die nachhaltigsten Firmen zu investieren, da diese eine positive Rendite gegenüber weniger nachhaltigen Firmen abwarfen (siehe zum Beispiel Gompers, Ishii, und Metrick, 2003). Bebchuk und seine Co-Autoren konnten im Jahre 2013 jedoch belegen, dass dieser Effekt nicht mehr vorhanden ist und keine überaus positiven Renditen mit einem solchen Investmentansatz zu erwirtschaften sind. Ein Grund dafür ist die Tatsache, dass der Markt all diese Faktoren bereits in die Aktienkurse eingepreist hat und daher keine abnormalen Renditen mehr zu realisieren sind.

Daher argumentiere ich, dass institutionelle Anleger nur dann nachhaltig und verantwortlich investieren, wenn sie sich aktiv daran beteiligen, weniger nachhaltige Unternehmen nachhaltiger und verantwortlicher zu gestalten, und somit auch finanziell davon profitieren können. Aber wie können sich Anleger aktiv in ein Unternehmen einbringen?

Die vier empirischen Kapitel der vorliegenden Dissertation beschäftigen sich mit den wichtigsten zwei Maßnahmen, die Aktionäre nutzen können, um Unternehmen zu beeinflussen und deren ökologische, soziale, und ethische Qualität zu verbessern. Dazu gehört zum einen das Einreichen von Aktionärsanträgen auf Jahreshauptversammlungen und zum anderen das direkte Engagement bei den investierten Firmen durch direkte Kontaktaufnahme mit dem Management oder dem Aufsichtsrat. Diese beiden Maßnahmen fasse ich unter dem Begriff „Aktionärs-Engagement“ zusammen, welches dem im angelsächsischen Raum bekannten Begriff shareholder engagement entspricht.

Im Folgenden wird diese Zusammenfassung die wichtigsten theoretischen Grundlagen sowie empirischen Ergebnisse eines jeden Kapitel erläutern.

Kapitel Zwei dieser Dissertation beschäftigt sich mit dem US-amerikanischen Kapitalmarkt und beleuchtet die Wahrscheinlichkeit, dass Unternehmen mit AktionärsAnträgen auf einer Jahreshauptversammlung (JHV) konfrontiert werden. Aktionärsanträge sind Anträge die in den Vereinigten Staaten von Amerika von jedem Aktionär eingereicht werden können, der mindestens 1\% der sich im Umlauf befindlichen Aktien hält, oder mit mindestens 2.000 US Dollar am Unternehmen beteiligt ist. Oftmals fordern Aktionäre in ihren Anträgen, dass bestimmte Geschäftspolitiken verändert werden, dass die Höhe der Vergütungen begrenzt wird, oder dass die Zusammensetzung des Management Teams oder Aufsichtsrates geändert wird. Im Allgemeinen zielen diese Anträge darauf ab, den Wert eines Unternehmens zu steigern, aber gleichzeitig auch eine nachhaltigere Unternehmenspolitik durchzusetzen. Daher ist die Frage nach 
der Konfrontationswahrscheinlichkeit eine wichtige Fragestellung für Manager als auch für Aktionäre.

Grundhypothese dieses Kapitels ist, dass Unternehmen, die einer mangelnden Kontrolle durch zwei externe Mechanismen unterliegen, - dem sogenannten Übernahmemarkt sowie durch Konkurrenzdruck - eine höhere Wahrscheinlichkeit aufweisen, mit Aktionärsanträgen konfrontiert zu werden. Das heißt, dass Aktionäre schlecht kontrollierte Unternehmen identifizieren können und diese infolgedessen mit Anträgen konfrontieren. Durch Giroud und Mueller (2011) sowie Gompers, Ishii, und Metrick (2003) wurde bereits belegt, dass sowohl der Übernahmedruck durch konkurrierende Unternehmen sowie der Konkurrenzdruck selbst als Corporate Governance Mechanismen funktionieren, die Manager dazu veranlassen, das Unternehmen besser zu führen und profitabler zu machen. Die empirischen Ergebnisse meines zweiten Kapitels stützen diese Hypothese: Schlecht kontrollierte Unternehmen weisen eine statistisch und ökonomisch höhere Wahrscheinlichkeit auf, mit Aktionärsanträgen konfrontiert zu werden.

Des Weiteren wird in diesem Kapitel untersucht, welche Faktoren die Abstimmungsresultate dieser Anträge beeinflussen. Wie viele Stimmen Aktionärsanträge auf der JHV schlussendlich bekommen ist eine Maßgröße für den Erfolg der Anträge. Zwar sind in Aktionärsanträge in den USA nicht bindend für das Management, d.h. selbst wenn die Anträge mehr als 50\% der Stimmrechte auf sich vereinigen können, muss das Management die Vorgaben des jeweiligen Antrages nicht zwingend implementieren. Die Bedeutung eines Abstimmungsresultates eines Aktionärsantrags über 20\% sollte jedoch nicht unterschätzt werden. Oft reicht ein solches Ergebnis aus, um genügend Druck auf das Management auszuüben, bestimmte Praktiken zu verändern. Die Arbeitshypothese zu den Abstimmungsergebnissen lautet, dass der Anteil von Stimmrechten, die sogenannte Unternehmens-Insider, also Manager, Aufsichtsratsmitglieder, und andere dem Management nahe stehende Personen, auf sich vereinigen, einen negativen Einfluss auf die Abstimmungsergebnisse von Aktionärsanträgen haben, da diese UnternehmensInsider generell gegen Aktionärsanträge stimmen. Auch hier belegen die empirischen Ergebnisse meine Hypothese: Die Stimmrechte von Unternehmens-Insider haben einen negativen Einfluss auf die Ergebnisse von Aktionärsanträgen bei Abstimmungen auf der JHV. Zum einen argumentiere ich in diesem Kapitel, dass die Unternehmens-Insider selbst gegen diese Anträge stimmen, zum anderen können auch die Managementempfehlungen zu jedem der Aktionärsanträge einen negativen Einfluss haben, da diese in den meisten Fällen eine Empfehlung gegen diese Anträge zu stimmen beinhaltet.

Zusammenfassend zeigt dieses Kapitel, dass Investoren - sowohl Kleinanleger als auch institutionelle Anleger - richtigerweise schlecht kontrollierte Unternehmen, die eine relative schlechtere finanzielle Performance aufweisen, mit ihren Anträgen auf Jahreshauptversammlungen konfrontieren. Des Weiteren wird die Effizienz eines Kontrollmechanismus durch Aktionärsanträge dadurch limitiert, dass Unternehmens-Insider ihre Stimmrechte dazu nutzen, um die Ergebnisse dieser Anträge negativ zu beeinflussen. Generell argumentiere ich, dass dieser Mechanismus durch Aktionärsanträge aber als wichtiger Bestandteil der Corporate Governance gesehen werden muss, da öffentlicher Druck auf Manager ausgeübt werden kann, selbst wenn die Abstimmungsergebnisse nicht über $20 \%$ liegen. 
Kapitel Drei meiner Dissertation untersucht ebenfalls den Kontrollmechanismus durch Aktionärsanträge. Dieses Kapitel fokussiert sich aber in seiner Fragestellung auf eine bestimmte Gruppe von Anträgen, nämlich die Anträge, die bereits im Vorfeld der JHV durch die Aktionäre wieder zurückgezogen werden, und welche daher nicht zur Abstimmung auf der Tagesordnung der JHV erscheinen. Dieses Kapitel zielt darauf ab, einerseits die Gründe für das Zurückziehen von Anträgen zu erläutern, und andererseits die statistischen und ökonomischen Bestimmungsgrößen aufzuzeigen, die dazu führen, dass einige Anträge zurückgezogen werden, und andere nicht.

In Kapitel Drei argumentiere ich, dass vor allem die Anträge von Aktionären, die nachteilig für Manager sein könnten, etwa hinsichtlich der Höhe der Vergütungen oder in anderer Weise der Reputation der Manager und Aufsichtsratsmitglieder schaden könnten, zurückgezogen werden. Ich schließe jedoch nicht aus, dass auch andere Anträge, die nicht direkt auf die Manager und deren Macht abzielen, zurückgezogen werden.

Wenn im Vorfeld der JHV alle Aktionärsanträge eingegangen sind, hat das Management in den Vereinigten Staaten die Möglichkeit den eingereichten Antrag entweder zur Abstimmung auf der JHV zuzulassen, ihn abzulehnen, oder den einreichenden Aktionär zu Verhandlungen über eine Zurückziehung des Antrags einzuladen. Dies bedeutet im Rückschluss, dass nicht alle eingereichten Anträge auch zur JHV zugelassen. Das Management darf bestimmte Anträge ablehnen, wenn die Finanzaufsichtsbehörde, die Securities and Exchange Commission (kurz SEC), dies erlaubt. In den meisten Fällen geschieht eine Ablehnung, wenn der Antrag grundsätzliche Veränderungen in den Geschäftsfeldern des Unternehmens fordert, wie z.B. die Umstrukturierung eines Chemiekonzerns in einen Mischkonzern.

Wie bereits erläutert, werden einige Aktionäre zu Verhandlungen über eine freiwillige Zurückziehung ihres Antrages eingeladen. In vielen Fällen sind diese Verhandlungen erfolgreich, und der Antragssteller zieht seinen oder ihren Antrag zurück. Falls die Verhandlungen nicht erfolgreich verlaufen, wird der Antrag in der Regel zur Abstimmung auf der JHV zugelassen. Dass Aktionärsanträge zurückgezogen werden, geschieht relativ oft in den USA. Meine Resultate in Kapitel Drei zeigen, dass durchschnittlich $20 \%$ aller in jedem Jahr eingereichten Anträge zurückgezogen werden, und somit nicht auf der Tagesordnung der JHV erscheinen. Warum aber ziehen so viele Aktionäre ihre eingereichten Anträge zurück?

Im dritten Kapitel argumentiere ich, dass dies meistens dann geschieht, wenn das Management einen zufriedenstellenden Kompromiss anbietet, wie z.B. die komplette oder zumindest die teilweise Implementierung der im Antrag formulierten Forderungen. Ansonsten würde der antragstellende Aktionär nicht freiwillig den Antrag zurückziehen. Daher bewerte ich - wie zum Beispiel auch Landier und Nair (2009) - einen zurückgezogenen Antrag als erfolgreiches Aktionärs-Engagement, da das Management den Antrag in gewisser Weise implementiert hat.

Der empirische Teil des dritten Kapitels geht der Frage nach, welche Faktoren dazu führen, dass Aktionäre ihren eingereichten Antrag zurückziehen. Dieser Analyse liegen drei Hypothesen zugrunde. Erstens argumentiere ich, dass Anträge von institutionellen Investoren eher zurückgezogen werden als Anträge von Kleinanlegern. Zweitens stelle ich die Hypothese auf, dass Aktionäre eher ihre Anträge zurückziehen, wenn diese bei 
Unternehmen eingereicht wurden, die einen hohen Anteil an institutionellen Anlegern aufweisen. Drittens argumentiere ich, dass der Anteil an Stimmrechten, die von Unternehmens-Insidern gehalten werden, einen negativen Einfluss auf die Wahrscheinlichkeit hat, dass Anträge vorab zurückgezogen werden.

Meine empirischen Ergebnisse stützen diese drei Hypothesen. Zum einen belegen meine Ergebnisse die These, dass Anträge von institutionellen Anlegern eher zurückgezogen werden, als Anträge, die von Kleinanlegern eingereicht wurden. Ein Grund hierfür ist die Tatsache, dass sich Manager von institutionellen Anträgen stärker konfrontiert und unter Umständen einer negativen Presse ausgesetzt sehen, als das bei Anträgen von Kleinanlegern der Fall ist. Dies spiegelt auch die Verhandlungsstärke der institutionellen Anleger wider: Manager sind eher dazu bereit Kompromisse einzugehen und die in den Anträgen gestellten Forderungen ganz oder teilweise zu implementieren, wenn diese von Großanlegern vorgebracht werden. Ferner belegen meine Ergebnisse, dass Anträge eher zurückgezogen werden, wenn das Unternehmen einen hohen Anteil von institutionellen Anlegern aufweist. Dieser Effekt ist statistisch und ökonomisch signifikant, was bedeutet, dass Anträge am ehesten zurückgezogen werden, wenn diese bei Unternehmen mit einem hohen Anteil an institutionellen Aktionären eingereicht wurden. Abschließend stützen meine Ergebnisse meine dritte Hypothese: Halten Manager oder Aufsichtsratsmitglieder einen relativ höheren Anteil an Stimmrechten, wird es unwahrscheinlicher, dass ein Antrag zurückgezogen wird. Das bedeutet, dass Manager - sofern sie selbst ein großes Paket an Aktien halten - weniger dazu bereit sind, Kompromisse einzugehen und die Forderungen der Aktionäre zu implementieren. In diesem Falle sehen sich die Manager in günstigerer Verhandlungsposition und lassen dann den Antrag zur Abstimmung auf der JHV zu. Dann können sie ihre Stimmrechte selbst ausüben und gegen den jeweiligen Aktionärsantrag stimmen und so das Abstimmungsergebnis $\mathrm{zu}$ ihren Gunsten beeinflussen - wie auch in Kapitel Zwei beschrieben wurde.

Zusammenfassend kann konstatiert werden, dass meine Ergebnisse in Kapitel Drei auf die außergewöhnlich wichtige Rolle von institutionellen Anlegern in der Corporate Governance hinweisen. Grundlage für diese Behauptung sind die empirischen Ergebnisse dieses Kapitels: Manager sind eher dazu bereit, Aktionärsanträge zu implementieren, wenn diese von institutionellen Anlegern eingereicht wurden und wenn der Anteil von institutionellen Anlegern am Unternehmen hoch ist.

In Kapitel Vier meiner Dissertation beleuchte ich die Aktionärs-Engagement Aktivitäten eines großen britischen Vermögensverwalters etwas genauer. Dieser Vermögensverwalter ist verantwortlich für mehr als 100 Milliarden US Dollar und führt die direkten Aktionärs-Engagements für weitere institutionelle Anleger, wie Versicherungen oder Pensionskassen aus. Wie weiter oben beschrieben, beinhaltet Aktionärs-Engagement alle Maßnahmen, die von Aktionären ergriffen werden, um Unternehmenspraktiken zu verändern, Unternehmen nachhaltiger zu machen, oder Managementvergütungs-Systeme zu reformieren. Kapitel Vier beschäftigt sich mit allen Maßnahmen, die von dem genannten britischen Vermögensverwalter ergriffen wurden, um - im Auftrag von weiteren institutionellen Anlegern - Unternehmen und deren Verhalten zu verändern. Dazu zählen der direkte, aber private, Management-Kontakt (über Telefonate, Emails oder Briefe), Unternehmensbesuche, regelmäßiger Email Kontakt zu Vorstandsmitgliedern, und 
andere Kontaktaufnahmen, die allesamt dazu genutzt werden, um die ökologischen, sozialen, und ethischen Aspekte eines Unternehmens zu verbessern.

Der hier beschriebene britische Vermögensverwalter ermöglichte mir Einblicke in seine Engagement Politik und stellte mir seine vertraulichen Daten über die jeweiligen Engagements zur Verfügung. Mittels dieser Daten war es mir möglich, alle einzelnen Engagements bei 397 Unternehmen aus 37 verschiedenen Ländern zu analysieren. Ferner stellte mir der Vermögensverwalter alle Informationen über erfolgreiche Engagements zur Verfügung. Das heißt, dass ich in meiner Studie genau nachvollziehen kann, wann und bei welchem Unternehmen ein Engagement erfolgreich war. Dies bedeutet, dass meine Studie in Kapitel Vier eine der ersten Studien ist, die direkte Rückschlüsse auf den Erfolg von Aktionärs-Engagement zulässt.

Grundidee dieses Kapitels ist die Untersuchung der geografischen Breite der Engagements des britischen Vermögensverwalters. Dies ist vor allem wichtig vor dem Hintergrund der Tatsache, dass dieser Vermögensverwalter von anderen institutionellen Großanlegern aus ganz Europa angeheuert wird, ihre Engagements durchzuführen, da sie unter Umständen nicht die Kapazitäten besitzen, selbst Aktionärs-Engagements durchzuführen.

Die Haupthypothese dieses Kapitels lautet, dass britische Unternehmen eher vom untersuchten Vermögensverwalter mit Engagement konfrontiert werden, als Unternehmen aus anderen Kapitalmärkten, wie z.B. den USA oder Kontinentaleuropa. Dieser These liegen die Ergebnisse der Investmentliteratur zu Grunde - wie z.B. Coval and Moskowitz (1999) -, die belegen, dass Investoren vor allem in naheliegende Unternehmen investieren, die sie kennen und sich daher eher mit diesen identifizieren können (das sogenannte „home bias“). In meinem Kapitel schreibe ich auch möglichen Informations-Asymmetrien und Transaktionskosten eine wichtige Rolle bei der Entscheidung über bestimmte Engagements zu, da der Vermögensverwalter eine genaue Auswahl über die Ziele seines Engagements treffen muss. Da Informations-Asymmetrien und Transaktionskosten von Aktionärs-Engagement im heimischen Kapitalmarkt niedriger sind, als bei Engagements im Ausland, behaupte ich, dass britische Unternehmen häufiger das Ziel der Aktionärs-Engagements sind, als ausländische Firmen.

Die empirischen Ergebnisse dieses Kapitels bestätigen meine Hypothese: Britische Unternehmen weisen statistisch und ökonomisch mehr Engagements auf, als ausländische Unternehmen. Die Implikationen sind vor allem für andere institutionelle Anleger von großer Bedeutung. Wenn zum Beispiel ein deutscher institutionelle Investor Aktionärs-Engagement durchführen möchte und einen ausländischen Vermögensverwalter auswählt, um diese Engagements auszuführen, muss sich der deutsche Anleger dessen bewusst sein, dass der ausländische Vermögensverwalter unter Umständen eine ganz andere geografische Ausrichtung besitzt, als der deutsche Investor selbst. Dies kann dazu führen, dass sich die Engagements auf einzelne Unternehmen konzentrieren, die für den deutschen Investor nicht unbedingt von höchster Wichtigkeit sind. Daher machen meine empirischen Ergebnisse deutlich, dass sich Investoren bewusst sein müssen, welchen geografischen Fokus das Engagement-Portfolio des angeheuerten Engagement-Anbieters tatsächlich hat. 
Die Untersuchung der erfolgreichen Aktionärs-Engagements ergibt, dass Unternehmen aus dem US-amerikanischen Raum und aus Japan die höchsten Erfolgsraten aufweisen. Diese Ergebnisse bedeuten, dass der britische Vermögensverwalter zwar häufiger einheimische, britische Unternehmen mit Engagements konfrontiert, aber in bestimmten ausländischen Märkten erfolgreicher die Unternehmenspolitik beeinflusst. Eine mögliche Erklärung hierfür ist vor allem die ebenfalls vorhandene Ressourcenknappheit beim Vermögensverwalter selbst. Dieser unterzieht ausländische Unternehmen einer sorgfältigeren Voruntersuchung, bevor tatsächliche Engagements durchgeführt werden, als dies bei einheimischen Unternehmen der Fall ist. Daher werden womöglich nur diese Engagements durchgeführt, für welche sich der Vermögensverwalter die größte ex-ante Erfolgswahrscheinlichkeit errechnet.

Zusammenfassend kann festgehalten werden, dass die privaten AktionärsEngagements durch spezialisierte Intermediär-Unternehmen, wie den hier beschriebenen britischen Vermögensverwalter, eine durchaus praktikable Alternative zu den gängigen, publik durchgeführten Engagement Methoden, wie z.B. Aktionärs-Anträge darstellen. Zwar sollten sich Investoren einer gewissen Tendenz dieser Intermediäre bewusst sein, eher einheimische Firmen anzusprechen (das sogenannte „home bias“). Die Erfolgsraten solcher Aktionärs-Engagements sind durchaus ansehnlich und stellen daher für institutionelle Anleger eine effiziente Methode dar, sich aktiv an der Corporate Governance zu beteiligen.

Im fünften und letzten empirischen Kapitel dieser Arbeit kombiniere ich die zugrundeliegenden Datensätze aus den vorangegangenen Kapiteln. Das Ziel dieses Kapitels ist es, die Interaktion von publik durchgeführten Aktionärs-Engagements, also AktionärsAnträgen, und von privaten Engagements, also den privaten Kontaktaufnahmen durch wie den in Kapitel Vier beschriebenen britischen Vermögensverwalter zu dokumentieren. Folgender Grundgedanke steht bei diesem Kapitel im Vordergrund: Viele Unternehmen werden sowohl mit publik durchgeführten, aber gleichzeitig auch mit privaten Aktionärs-Engagements konfrontiert. Die Eigentümerbasis von Unternehmen ist oft sehr breit gestreut und besteht aus einer Vielzahl von verschiedenen institutionellen Investoren. Daher liegt es nahe anzunehmen, dass Unternehmen, sowohl mit publiken Engagements als auch mit privaten konfrontiert werden. Die Frage wie diese beiden Mechanismen interagieren und die Wahrscheinlichkeit beeinflussen, mit Aktionärs-Engagements konfrontiert zu werden, steht im Mittelpunkt dieses Kapitels. Des Weiteren wird untersucht, was den Erfolg der verschiedenen Aktionärs-Engagements beeinflusst. Hier spielt auch die Zusammenwirkung von publiken und privaten Aktionärs-Engagement Strategien womöglich eine wichtige Rolle, da diese unter Umständen positiv zu einander korreliert sind.

Meine empirischen Ergebnisse dieses Kapitels verdeutlichen die Bedeutung beider Engagement Strategien (publik und privat) für die Wahrscheinlichkeit das Unternehmen auch in Zukunft mit mindestens einem dieser beiden Mechanismen konfrontiert werden. Dies bedeutet, dass Firmen, die mit publiken und privaten Aktionärs-Engagements konfrontiert werden, weisen eine statistisch und ökonomisch signifikant höhere Wahrscheinlichkeit auf, auch im kommenden Jahr mit mindestens einem dieser beiden Mechanismen konfrontiert zu werden. Ferner kann ich die These belegen, dass Unternehmen, die 
eine hohe Reputation hinsichtlich publiker Engagement Strategien aufgebaut haben eine höhere Wahrscheinlichkeit aufweisen, auch in Zukunft häufiger publike AktionärsEngagements zu implementieren. Diese Ergebnisse haben eine große Bedeutung für institutionelle Anleger, die sich aktiv an der Corporate Governance beteiligen wollen, und für Unternehmen, die sich verschiedener Aktionärs-Engagements ausgesetzt sehen. Die Ergebnisse können helfen, dass institutionelle Anleger besser attraktive Ziele für ihre Engagements auswählen.

Alles in allem verdeutlicht die vorliegende Dissertation, dass Aktionäre - sowohl Kleinanleger aber auch institutionelle Investoren - mehrere Möglichkeiten besitzen, sich aktiv an der Corporate Governance zu beteiligen und auch ökologisches, soziales, und ethisches Fehlverhalten von Unternehmen zu korrigieren. Im Falle eines institutionellen Anlegers sollte dies in engem Dialog mit den eigenen Kunden und Benefizianten erfolgen. Institutionelle Investoren haben die ökonomische Macht, von Unternehmen gehört zu werden und sollten daher noch stärker Teil der Corporate Governance werden. Dabei geht es nicht darum, Renditen aufzugeben, sondern vielmehr darum, Renditen noch verantwortlicher und nachhaltiger zu erwirtschaften. Aktionärs-Engagements, wie sie in dieser Arbeit beschrieben wurden, stellen eine Möglichkeit dar. Auf der anderen Seite sollten sich auch Kleinanleger stärker in die Coprporate Governance einbringen, indem sie z.B. aktiv von ihrem Stimmrecht auf der JHV Gebrauch machen. Dies kann durchaus auch über Treuhänder geschehen.

Ein Investor sollte sich meiner Meinung nach jederzeit darüber bewusst sein, dass mit einer gewissen ökonomischen Macht auch eine gesellschaftliche Verantwortung einhergeht, die es zu erfüllen gilt. 



\section{Curriculum Vitae}

Peter Michael Viehs was born on 13 February 1985 in Aachen, Germany. He attended high school at the Gymnasium der Gemeinde Kreuzau and studied at Maastricht University International Business Economics. He obtained his Bachelor of Science in 2007. Afterwards, he studied International Business with concentration Finance at Maastricht University and graduated in 2008 with the Master of Science. During his studies, Michael visited the University of St. Gallen, Switzerland, for an exchange semester.

In September 2008, he joined the Finance Department of the School of Business and Economics at Maastricht University as a teaching assistant. Back then, he was involved in teaching undergraduate courses on corporate governance, investment management, corporate finance and accounting. In January 2009, Michael became a Ph.D. student at both the Department of Finance and Department of Accounting and Information Management at the School of Business and Economics.

In 2012, Michael attended Oxford University School of Geography as a visiting scholar to work under the supervision of Prof. Gordon Clark. Substantial parts of this dissertation have been completed during Michael's time in the UK.

As a PhD candidate, Michael was responsible for teaching graduate students in the fields of corporate governance, institutional investors, and fixed-income management. Michael presented his work at several top-notch academic conferences including the conference on Financial Globalisation and Sustainable Finance in Cape Town, South Africa, the Annual Meeting of the Financial Management Association (FMA) in Atlanta, USA, the $10^{\text {th }}$ International Conference on Corporate Governance in Birmingham, UK, the Graduate Student Conference on Institutional Investors in Oxford, UK, the Conference on Finance and Responsible Business Practices: Research, Practice and Policy at Haas School of Business in Berkeley, USA, the $9^{\text {th }}$ Corporate Finance Day in Lille, France, the Mistra Workshop on Sustainable Investment Research in Bilbao, Spain, and the Mistra Workshop on Fiduciary Duties in Gothenburg, Sweden.

He also held multiple industry presentations at, for example, Nordea Asset Management, F\&C Asset Management, Generation Investment Management and Hermes Equity Ownership Services. He was also involved in writing research reports for Deutsche Bank.

Since September 2013, Michael is a Research Fellow at University of Oxford Smith School of Enterprise and the Environment. He also is affiliated with The European Centre for Corporate Engagement (ECCE). 